\title{
Veinte peruanos del siglo XX
}

Manuel González Prada - Francisco García Calderón - Víctor Andrés Belaunde José de la Riva-Agüero y Osma - César Vallejo - Honorio Delgado José Luis Bustamante y Rivero - Pedro G. Beltrán - José Carlos Mariátegui

Víctor Raúl Haya de la Torre - Raúl Porras Barrenechea Luis Alberto Sánchez - Jorge Basadre - José María Arguedas Fernando Belaunde Terry - Luis Bedoya Reyes - Fernando de Szyszlo Blanca Varela - Luis Banchero Rossi - Mario Vargas Llosa

Pedro Cateriano Bellido (Compilador)

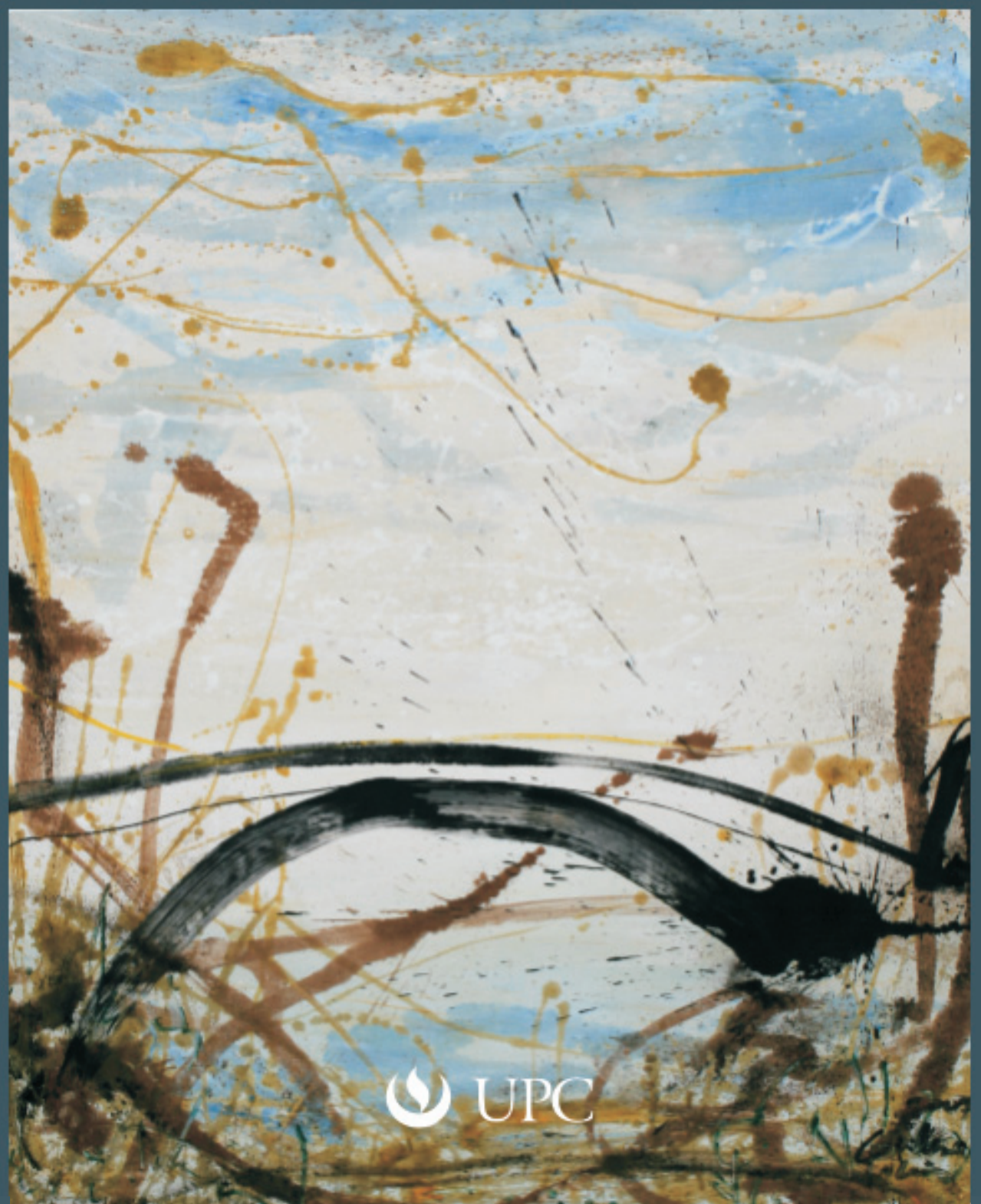





\section{Veinte peruanos del siglo XX}

Manuel González Prada - Francisco García Calderón - Víctor Andrés Belaunde

José de la Riva-Agüero y Osma - César Vallejo - Honorio Delgado José Luis Bustamante y Rivero - Pedro G. Beltrán - José Carlos Mariátegui

Víctor Raúl Haya de la Torre - Raúl Porras Barrenechea

Luis Alberto Sánchez - Jorge Basadre - José María Arguedas

Fernando Belaunde Terry - Luis Bedoya Reyes - Fernando de Szyszlo

Blanca Varela - Luis Banchero Rossi - Mario Vargas Llosa

Pedro Cateriano Bellido (Compilador)

Lima, diciembre de 2010

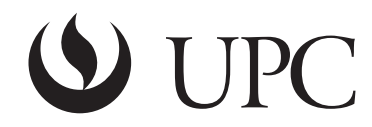



Compilador: Pedro Cateriano Bellido

(C) Universidad Peruana de Ciencias Aplicadas (UPC)

Primera edición: diciembre de 2010

Cubierta:

Corrección de estilo:

Guillermo Palacios Pomareda

Diseño de cubierta:

Jorge Coaguila

Diagramación:

Fotografías:

Giuliana Abucci

Roxana Ishii

Vicente de Szyszlo (álbum familiar)

Universidad Peruana de Ciencias Aplicadas SAC

Av. Alonso de Molina 1611, Lima 33, Perú

Telef. 313-3333

http://www.upc.edu.pe

Digitalizado y Distribuido por YoPublico S.A.C.

\section{Dyopublico}

www.yopublico.net

Telf: 51-1-221 9998

Dirección: Av. 2 de Mayo 534

Of. 304, Miraflores Lima-Perú

\section{Universidad Peruana de Ciencias Aplicadas (UPC) \\ Centro de Información}

Pedro Cateriano Bellido (compilador). Veinte peruanos del siglo XX

Lima: Universidad Peruana de Ciencias Aplicadas (UPC), 2015

ISBN de la versión impresa: 978-603-4019-90-4

ISBN de la versión PDF: 978-612-4041-59-4

ISBN de la versión e-Pub: 978-612-4191-52-7

BIOGRAFÍAS, INTELECTUALES, POLÍTICOS, PRESIDENTES, LITERATOS, MÉDICOS, PINTORES, EMPRESARIOS, PERÚ

\subsection{CHAN}

Todos los derechos reservados. Esta publicación no puede ser reproducida, ni en todo ni en parte, ni registrada en o transmitida por un sistema de recuperación de información, en ninguna forma ni por ningún medio, sea mecánico, fotoquímico, electrónico, magnético, electroóptico, por fotocopia o cualquier otro, sin el permiso previo, por escrito, de la editorial.

El contenido de este libro es responsabilidad de los autores y no refleja necesariamente la opinión de los editores. 
Serie Puente Villena

Técnica mixta $185 \times 150 \mathrm{~cm}$ 2007

La Universidad Peruana de Ciencias Aplicadas (UPC) agradece a Guillermo Palacios Pomareda la cesión de su cuadro reproducido en la cubierta. 

Manuel González Prada (1844-1918)

Eugenio Chang-Rodríguez

Francisco García Calderón (1883-1953)

Osmar Gonzales Alvarado

Víctor Andrés Belaunde (1883-1966)

Diego García-Sayán

José de LA Riva-AgÜERo y Osma (1885-1944)

José Agustín de la Puente Candamo

César VAllejo (1892-1938)

Liliana Checa

Honorio Delgado (1892-1969)

Renato D. Alarcón-Guzmán

José Luis Bustamante y Rivero (1894-1989)

José Luis Sardón

Pedro G. Beltrán (1894-1979)

Arturo Salazar Larraín

José Carlos Mariátegui (1894-1930)

Iván Alonso

Víctor Raúl Haya de la Torre (1895-1979)

Carlos Espá

Raúl Porras Barrenechea (1897-1960)

Carlota Casalino Sen 
Luis Alberto SÁnchez (1900-1994)

Ismael Pinto Vargas

Jorge BASADRE (1903-1980)

Rocío Chirinos Montalbetti

José María Arguedas (1911-1969)

Santiago Pedraglio

Fernando Belaunde Terry (1912-2002)

Miguel Cruchaga

Luis Bedoya Reyes (1919- )

Lourdes Flores Nano

Fernando de Szyszlo (1925- )

Mariella Balbi

Blanca Varela (1926- )

Giovanna Pollarolo

LuIs BANCHERo Rossi (1929-1972)

Daniel Córdova Cayo

Mario Vargas Llosa (1936- )

Pedro Cateriano Bellido

299

RESEÑAS DE LOS AUTORES DE LOS TEXTOS 


\section{Presentación}

Destacar, entre otros, resulta condición indispensable para que la historia y los diccionarios reconozcan la definición de personaje.

Referirse a un personaje exige considerar la personalidad como un elemento básico e imprescindible. Plantea reconocer el conjunto de características y diferencias individuales que nos distinguen de otros, volviéndonos particulares e inconfundibles.

Estos ensayos no cuentan historias. Presentan formas de hacer historia.

Uno puede tener el deseo de convertirse en un personaje de la historia. No obstante, el mérito reside, justamente, en lograr que sean los otros los que encuentren en uno a un personaje con historia; a un personaje de la historia.

Este libro es una oportunidad para que veinte autores peruanos de diferentes generaciones y diversas ideologías, puntualmente seleccionados, acerquen a los lectores a veinte peruanos que durante el siglo XX evidenciaron una destacada participación en el pensamiento político, en la economía y en la cultura nacional del Perú.

Se trata, qué duda cabe, de un número arbitrario que por la exigencia de ser finito, explica su selección en función de su relación con el siglo que acabamos de finalizar, y cuya estela sigue siendo parte de nuestro océano.

Estamos conscientes de que el siglo nos ha dado muchos nombres adicionales; que le debemos una momentánea explicación a todas aquellas valiosas personas que colaboraron, desde sus quehaceres, con el desarrollo moral, político, económico y cultural del país.

Sin embargo, es indispensable que se comprenda que la selección de los personajes que presentamos, realizada al interior de la Universidad, se ha basado, fundamentalmente, en evidencias de biografías edificantes; en ideas que han guiado y marcado la historia del país, así como en el gran reconocimiento nacional e internacional labrado durante sus vidas.

Los autores de los textos, por su parte, son versados en la materia tratada y, en varios casos, han conocido, estudiado o trabajado directamente con los personajes centrales del libro. Ello convierte a cada uno de los ensayos en textos con personalidad y responsabilidad propias. 
Estos ensayos tienen, además, la profunda virtud de presentarnos personajes del siglo XX mientras, simultáneamente, describen y presentan a los autores. Cada ensayo nos muestra, sin habérselo planteado siquiera, la jerarquización, las huellas y la postura de sus autores. No cabe duda que se trata de un libro que invitará al debate.

Para la construcción y redacción de los textos, los autores han gozado de la mayor libertad de creación, llegando inclusive, en algunos casos, a esbozar apreciaciones o calificaciones personalísimas.

La idea es que a través de estos textos, cortos y de ágil lectura, los jóvenes conozcan a estos veinte grandes peruanos, y que su rica y variada trayectoria los ayude a comprender significativos sucesos acontecidos y sentidos en el Perú a lo largo del siglo XX.

El Fondo Editorial de la UPC quiere agradecer muy sinceramente al doctor Pedro Cateriano Bellido, compilador de esta obra, quien tuvo a bien compartir su proyecto con nosotros y trabajarlo, palmo a palmo, con cada uno de los autores. Sin su dedicación y cariño por recordar lo edificante y constructivo de los personajes seleccionados, este libro no habría sido posible.

A los autores de cada ensayo nuestro más sincero agradecimiento por haber aceptado el encargo con profesionalismo e indescriptible competencia.

Del mismo modo, la UPC quiere y debe dejar constancia de su agradecimiento a REPSOL YPF del Perú, empresa que con su contribución ha hecho posible la edición de este libro.

Lima, diciembre de 2008

Úrsula Freundt-Thurne Freundt

Directora del Fondo Editorial de la Universidad Peruana de Ciencias Aplicadas (UPC) 
Manuel González Prada

(1844-1918)

Eugenio Chang-Rodríguez 



\section{UNA VIDA EJEMPLAR}

Manuel González Prada, el más egregio pensador progresista peruano de fines del siglo XIX y principios del siglo XX, tiene un lugar prominente en la historia literaria latinoamericana. Sus escritos nutrieron e inspiraron a varias generaciones de sus discípulos deseosos de democratizar y modernizar el Perú. Nació en Lima este tercer vástago de Francisco González de Prada y Marrón de Lombera (1815-1863) y Josefa (Pepa) de Ulloa y Rodríguez de la Rosa (1820-1887), ambos de destacadas familias aristocráticas y religiosas. Manuel recibió la educación básica en Valparaíso y en Lima en el Seminario de Santo Toribio y en el Convictorio de San Carlos, plantel que ofrecía estudios secundarios y universitarios. En vez de concentrarse en los libros de texto, prefirió dedicarse a escribir versos y a leer obras literarias y discursos de congresistas liberales. A los dieciocho años de edad ya había compuestos algunos centenares de versos que no publicó ni compartió con nadie. Ganado por el interés literario, desechó el consejo paterno de recibirse de abogado, aunque aprobó todos los cursos de esa carrera y se retiró del convictorio sin obtener ningún grado universitario.

Hacia 1870 el joven Manuel se estableció en Tutumo, una de las propiedades familiares en el valle de Mala, provincia de Cañete, al sur de Lima, vecina a los contrafuertes andinos. Retirado en esa finca campestre, continuó leyendo a los clásicos de la lengua castellana, especialmente a Quevedo, Góngora, Fray Luis de Granada, los Argensola, Gracián, Cervantes y el Inca Garcilaso de la Vega, además de seguir familiarizándose con las obras de Goethe, Heine y otros grandes escritores alemanes. A veces interrumpía sus lecturas para estudiar química y realizar experimentos conformes con su proyecto industrial para obtener almidón y otros derivados de la yuca cultivada en sus tierras de Mala.

Pronto se le reconoció como poeta destacado, particularmente después de ser incluido en el Parnaso peruano, antología editada por José Domingo Cortés en Valparaíso, en 1871. El inquieto escritor publicaba poco: una que otra colaboración en El Correo del Perú y lo demás iba al canasto de papeles, después de seleccionar para sus archivos baladas indígenas como «Supay», «Huatanay», «La invención de la quena», «La aparición del coraquenque», «Caridad de Velarde», «La llegada de Pizarro» y otras composiciones 
publicadas póstumamente por su hijo Alfredo y Luis Alberto Sánchez. Sus observaciones del sufrimiento de la población nativa, conversaciones con los pongos y yanaconas le proporcionaron material para componer las baladas que publicó de 1871 a 1873 en $E l$ Correo del Perú y las incluidas póstumamente en Baladas peruanas, como «El mitayo» y «Las tres flechas del inca».

\section{DE ROMÁNTICO A PRECURSOR DEL MODERNISMO}

Aunque a los dieciocho años de edad Manuel ya había compuesto algunos centenares de versos, en su mayoría románticos, poco a poco se fue inclinando hacia la renovación literaria conocida después como modernismo. Por esos años también compuso algunas piezas teatrales. De 1866 a 1867 había terminado por lo menos el drama romántico Amor y pobreza y el sainete en verso festivo "La tía y la sobrina». No contento con su propia producción escrita, se dedicó a traducir al castellano poemas alemanes. El 18 de setiembre de 1867, el diario limeño El Comercio publicó su primera letrilla, firmada escuetamente «Manuel G. P.», sin el aristocrático «de» usado por la familia González de Prada. Así, el rebelde Manuel abdicaba a su alto rango social. Hizo lo mismo al publicar siete poemas sentimentales en el Parnaso peruano.

Don Manuel fue admitido como socio de la Sección Artes y Letras del Círculo Literario, presidido por Francisco García Calderón, futuro presidente del país. A esa prestigiosa organización pertenecían Ricardo Palma, Luis Benjamín Cisneros y otros distinguidos escritores civilistas. Pese a su vinculación con instituciones prestigiosas, el joven escritor continuó manifestando rebeldía contra las tradiciones aristocráticas, plutocráticas, religiosas y políticas, que eventualmente desembocó en una actitud radical, afín a la de Francisco de Paula González Vigil (1792-1875), sobre quien don Manuel escribió un ensayo biográfico en 1890, identificándolo como «solitaria columna de mármol a orillas de un río cenagoso».

\section{DOS AMORES Y UN MATRIMONIO ANTES DE LA GUERRA Del PaCífico}

En una de sus ocasionales visitas a Lima, don Manuel se enamoró de Verónica Calvet de Bolívar, de unos veinticinco años de edad, cuando don Manuel frisaba los treinta. De sus vínculos amorosos nació Mercedes, en 1878. ¿Por qué no se casaron? Tal vez porque el año anterior Manuel había conocido a Adriana de Vernehuil y Conches, agraciada adolescente francesa, con quien se casaría en 1887 y desde entonces se convertiría en la «animadora» de su esposo.

En 1880, cuando los chilenos triunfantes se acercaban a Lima, don Manuel combatió defendiendo el cerro del Pino (a unos dos kilómetros al sur de Lima), vecino a Chorrillos, donde los invasores dos días antes habían prendido fuego a la ciudad. Después de cum- 
plir el deber de defender a la patria, el entristecido Manuel se encerró en la casa materna durante la mayor parte del cuatrienio de la ocupación de Lima. La catástrofe nacional fue definitoria para González Prada y su generación. La estela de pesimismo y revanchismo frustrado lo afectaron profundamente.

En un segundo aislamiento, don Manuel escribió piezas literarias. Durante cuatro años compuso un sainete satírico en versos octosilábicos, varias obras en prosa y otras piezas sarcásticas, además de una especie de poema cómico escenificado. Pero lo que más escribía con gusto eran letrillas, romances, epigramas, rondeles, sonetos, triolets y, sobre todo, balatas. También escribió varios ensayos de Ortometría.

\section{Presidencia del Círculo literario y de la Unión Nacional}

Cuando las tropas chilenas de ocupación abandonaron Lima en 1884, en virtud del Tratado de Ancón (1883), don Manuel puso fin a su aislamiento. Surgió de su segundo retiro, resuelto a predicar contra el desbarajuste moral y a enfrentarse a los responsables de la derrota. Con motivo de la muerte de Victor Hugo el 22 de mayo de 1885, don Manuel publicó en El Comercio una elegía en la que se identificó con sus objetivos vitales. A los pocos meses, para celebrar las Fiestas Patrias, don Manuel publicó en el mismo diario el artículo «Grau», que poco después fue reproducido como la pieza central del folleto $A$ los defensores de la patria, con trabajos de Ricardo Palma, José Antonio de Lavalle y otros escritores.

El conservador Club Literario de la capital peruana se convirtió en el Ateneo de Lima en 1885. Al año siguiente, Manuel dictó su conferencia requerida para su incorporación en esa institución. No obstante su creciente prestigio intelectual, el recién afiliado se desilusionó con la tradición literaria del Ateneo de Lima y, con un grupo de jóvenes, organizó el Círculo Literario como vehículo de una literatura basada en la ciencia y orientada así hacia el futuro. La nueva institución nació para «concurrir a la formación de una literatura eminentemente nacional ${ }^{1}$. En setiembre de 1887 el Círculo Literario lo eligió presidente para suceder a Luis Márquez, que se encontraba gravemente enfermo. $\mathrm{Al}$ asumir su puesto en el octubre siguiente, González Prada declaró en su discurso en el Palacio de la Exposición que consideraba al Círculo Literario como el «partido radical de nuestra literatura $»^{2}$.

En la celebración del 28 de julio de 1888, aniversario de la declaración de la independencia del Perú, en la que se recolectaron fondos para el rescate de las provincias cautivas Tacna y Arica, el ecuatoriano Miguel Urbina, con voz límpida, leyó en el Teatro Politeama de Lima la famosa disertación de González Prada «Discurso en el Politeama». Las felicitaciones por tan polémica pieza de oratoria, especialmente procedentes de pro-

1 Revista Social, nro. 72, 1 de noviembre de 1886.

2 Revista Social, nro. 120, 8 de noviembre de 1887. 
vincias, fueron difundidas por Abelardo Gamarra en La Integridad, para disgusto de los periódicos gubernamentales, que lo atacaban, condenaban y apoyaban su excomunión. El 30 de octubre de 1888, al cumplirse el año de la fundación del Círculo Literario, don Manuel aludió a don Ricardo Palma en su «Discurso en el Teatro Olimpo» cuando dijo: "Cultivamos una literatura de transición [...], ese monstruo engendrado por las falsificaciones agridulcetes de la historia y la caricatura microscópica de la novela [...]. Rompamos ese pacto infame y tácito de hablar a media voz».

En mayo de 1891 González Prada, Germán Leguía Martínez, Víctor Maúrtua, Luis Ulloa, Carlos Rey de Castro, el trujillano Wenceslao Cuadra y cuadros del Círculo Literario fundaron la Unión Nacional, cuya «Declaración de principios», redactada por don Manuel y publicada el 16 de mayo de 1891 en La Integridad, expresa objetivos reformistas para establecer un gobierno parlamentario dedicado a un programa de reformas sociales y medidas en defensa del indígena. Poco después, el nuevo partido político lo nombró su presidente.

\section{Estancia CUlTural EN EUROPA (1891-1998)}

En el mismo 1891, los integrantes de la Unión Nacional se sorprendieron y se decepcionaron al recibir la noticia de que don Manuel y Adriana viajaban a Europa para satisfacer un viejo deseo de ampliar sus horizontes culturales y olvidar las pérdidas de sus dos primeros vástagos muertos al poco tiempo de nacer en Lima.

Una vez instalado en París, don Manuel asistió asiduamente a las clases de Ernest Renan y Louis-Nicolas Ménard en el Collège de France, y a las salas de lectura de la Biblioteca Nacional. Allá hizo pesquisas sobre métrica, rítmica. Además, leyó tanto las obras de antropólogos sociales (Le Bon, Gumplowicz y Tarde), como de los anarquistas Bakunin y Kropotkin. En La Sorbona, escuchó las charlas del egiptólogo Henri Maspero (18461916) y concurrió a charlas sobre literatura china. Se matriculó como alumno libre de esa venerable institución de alta cultura, alternando su asistencia con visitas a los museos y concurrencia a la Comédie Française y a la ópera.

El 16 de octubre de 1891 nació Alfredo, el hijo esperado. Pasados los primeros meses de engreír al niño entrañable, don Manuel reasumió la búsqueda cultural. A menudo asistía a la Biblioteca Nacional, al Museo del Louvre y a diversos auditorios donde se pronunciaban conferencias sobre el positivismo de Comte. En Mi Manuel, su viuda recuerda detalles de su vida parisina: estuvo presente en los sepelios de varias personalidades de renombre internacional: Renan, Maupassant, Leconte de Lisle y Louis Pasteur. En los funerales de Guy de Maupassant escuchó a Émile Zola su apología al amigo y correligionario de la escuela realista. Concurrió a representaciones de obras teatrales clásicas y se entusiasmó con las conferencias sobre positivismo. 
Acatando la sugerencia de sus corresponsales peruanos, a mediados de 1894, González Prada publicó en la imprenta de Paul Dupont su libro Pájinas libres, escrito con innovadora ortografía. El libro circuló en el Perú merced a Abelardo M. Gamarra y otros admiradores de sus escritos, que deseaban contrarrestar la crítica de los conservadores, especialmente de los clericales, que en Arequipa habían quemado su efigie en plena plaza pública.

Después de vivir cuatro años en París, Manuel, Adriana y Alfredo dedicaron varias semanas a recorrer Bélgica y el sur de Francia antes de proseguir a Barcelona y después a Madrid. En España se relacionó con escritores republicanos, visitó la Biblioteca de la Real Academia Española (RAE), el Ateneo y trabó amistad con el político y escritor catalán Francisco Pi y Margall (1824-1901), ex presidente de la Primera República Española (febrero de 1873-enero de 1874). Con él, asistió a una de las sesiones de la RAE. Fueron meses de estudio, visitas a centros políticos y concurrencias al Teatro Español, donde actuaba la célebre María Guerrero, y al Teatro de la Princesa, donde disfrutó de sus comedias.

A los dos años en España, los esposos González Prada decidieron retornar al Perú, ante la insistencia de familiares y amigos. En marzo de 1898, en Burdeos, abordaron un vapor con destino a Colón en ruta al Callao.

\section{Del PROSElitismo POSITIVISTA A LA PRÉDiCA ANARQUISTA}

Los tres González Prada llegaron al Callao el 2 de mayo de 1898. Abelardo Gamarra y otros amigos de la Unión Nacional les dieron la bienvenida. En los días siguientes, le informaron lo ocurrido con su partido, debilitado por la claudicación de algunos miembros tránsfugas al grupo de Piérola. Al poco tiempo el rebelde pensador escribió su discurso "Los partidos y la Unión Nacional», en el que criticó al Poder Ejecutivo. El gobierno prohibió que su discurso «Libre pensamiento de acción» se leyera en el Teatro Politeama el 28 de agosto de 1898, en la conferencia organizada por la Liga de Librepensadores del Perú. En todo el país se protestó contra el atropello. Clausurada La Luz Eléctrica, la Unión Nacional editó el periódico Germinal para defender al pueblo contra el gobierno de Piérola, los gamonales y el clericalismo. En esa publicación, don Manuel publicó muchos artículos firmados con seudónimo. El gobierno clausuró Germinal valiéndose de un juez venal. González Prada respondió en agosto de 1899 fundando otro periódico: El Independiente.

Consolidado Eduardo López de Romaña en el poder, don Manuel lo atacó en La Idea Libre y otros periódicos. El nuevo régimen continuó la política pierolista contra la oposición y clausuró El Independiente. En este ambiente de zozobra, don Manuel se refugió en sus versos. En 1901 la animadora Adriana y su hijo Alfredito, con una maquinita de imprimir tarjetas, en seis meses de ardua labor en casa, publicaron Minúsculas, el primer poemario de don Manuel. 
Cuando Manuel Pardo Barreda, hijo del fundador del Partido Civil asumió la presidencia del país, la Unión Nacional, ya aliada con el Partido Liberal, propuso nombrar a González Prada candidato presidencial. Don Manuel declinó postular tanto a la presidencia como a la vicepresidencia. Inaugurado el nuevo régimen civilista, don Manuel continuó colaborando con los obreros. Usando seudónimos, publicó muchos artículos en Los Parias, periódico ácrata de gran circulación en las masas proletarias. En esos artículos, don Manuel censuró acerbamente la organización social y política del país e inició una intensa campaña indigenista como reacción al incremento de los abusos contra los amerindios. Su mensaje circuló profusamente en provincias. En la Federación de Obreros Panaderos, que celebrara el Día del Trabajo el 1 de mayo de 1905, don Manuel pronunció el discurso «El intelectual y el obrero». Su pieza de oratoria estaba impregnada de ideas socialistas parecidas a las que circulaban en Europa. El 20 de setiembre del mismo 1905, don Manuel y Dora Mayer (1868-1957) pronunciaron sendos discursos en la logia masónica Stella d'Italia, con motivo de la celebración del día nacional de Italia. Prada se ocupó de «Italia y el papado».

Aconsejado por su «animadora», don Manuel reunió en 1908 varios ensayos suyos y los publicó en forma de libro, con el título Horas de lucha. Este tercer volumen impreso fue bien acogido, especialmente por los librepensadores y masones, que le organizaron en la logia Stella d'Italia una velada en su honor. En 1909 Prada publicó su cuarto libro: Presbiteriana. Por su virulento ataque anticlerical, y para no comprometer al periódico Los Parias, donde se imprimió, el volumen apareció anónimamente. Su segundo poemario y quinto libro, Exóticas, fue lanzado en 1911.

\section{LA DIRECCIÓN DE LA Biblioteca NACIONAL Y EL INFARTO MORTAL}

Varias veces los admiradores de González Prada trataron de convencerlo de que aceptara una posición gubernamental, un puesto estatal. Don Manuel no accedió hasta que Germán Leguía y Martínez, cofundador de la Unión Nacional, al ser nombrado ministro de Estado, nombró a su correligionario don Manuel director de la Biblioteca Nacional en marzo de 1912. Inmediatamente, Ricardo Palma y sus amigos criticaron su actitud. Algunos, despiadadamente, lo llamaron «Catón de alquiler». González Prada les respondió publicando una «Nota informativa sobre la Biblioteca Nacional», en la que señalaba las deficiencias en esa venerable institución. Los jóvenes discípulos de don Manuel lo respaldaron y acudieron a su casa a escuchar sus enseñazas, consejos y orientación intelectual.

$\mathrm{Al}$ mes siguiente de que el coronel Óscar R. Benavides asaltara el poder, febrero del 1914, el Congreso títere lo nombró a este presidente provisional del Perú. En protesta por ese acto de fuerza militarista, don Manuel presentó su renuncia irrevocable a la dirección de la Biblioteca Nacional. Con perversidad, el gobierno no la aceptó e inmediatamente 
lo destituyó. González Prada aceptó el desafío y lanzó el periódico La Lucha, pero toda la primera edición fue incautada por la Policía. Ante la represión soldadesca, don Manuel escribió Bajo el oprobio, libro que solo se publicaría póstumamente. Afortunadamente, en setiembre de 1915, José Pardo y Barreda retornó al gobierno y, en febrero de 1916, restituyó a González Prada en la dirección de la Biblioteca Nacional.

En el ínterin, Colónida y otras importantes revistas culturares aparecieron en Lima y provincias. En su despacho de director de la Biblioteca Nacional y en su casa aumentó el número de visitantes intelectuales que estaban en busca de orientación intelectual y revaloración de las ideas durante la crisis de la Primera Guerra Mundial. Para don Manuel, 1918 fue un año de hondas preocupaciones, como lo revelaron los escritos inéditos que arrumaba en su escritorio de casa mientras desempeñaba la dirección de la Biblioteca Nacional. Presintiendo la aproximación de la muerte, escribió composiciones contra las crueldades encontradas en la vida. Murió de un infarto cardiaco a las 12:40 de la tarde del 22 de julio de 1918. Así partió el maestro, dejando su obra inconclusa. Por suerte, había plantado semillas cuyos frutos cosecharían sus numerosos discípulos.

\section{APORTACIONES LITERARIAS}

Manuel González Prada realizó sus principales aportes intelectuales en el ámbito de las letras. Compuso versos con temas sociales. Cuando la métrica hispana no le ayudaba a expresarse como deseaba, recurría a esquemas de rima de otras literaturas. Del alemán tomó las baladas; del francés, los rondeles y triolets; del italiano, los respetos y balatas; y del Oriente, las técnicas artísticas persas y malayas. Todo ello le ayudó a convertirse en un precursor del movimiento literario hispanoamericano modernista, papel elogiado por críticos. Al leer los versos de González Prada, comprendemos a Kant, quien afirmó que una de las metas de la poesía es transformar los conceptos en ideas estéticas. Compuso poemas en su mayoría recopilados y editados póstumamente en las colecciones Libertarias (1938), Baladas peruanas (1939), Letrillas (1975) y Cantos de otro siglo (1878), o que permanecen inéditos en la Biblioteca Nacional del Perú.

Así como dio pautas de versificación, González Prada también legó recomendaciones para escribir en prosa. Deseosos de promover una revolución en las letras nacionales, y cuando desempeñaba el papel de portavoz de las inquietudes de los autores de avanzada, en el Círculo Literario anunció la posibilidad de una literatura radical. Empeñado en que el escritor responda a la lengua y a la realidad geográfico-social americana, don Manuel recomendó no usar el despojo seco de las cosechas extranjeras y no repetir pensamientos ajenos. Así como Emerson se quejó que se imitara a Shakespeare durante dos siglos, González Prada lamentó objetivamente, sin sentimiento antiibérico, que los peruanos del siglo XIX imitasen servilmente a Espronceda, Campoamor y Bécquer. Según González 
Prada, el escritor puede conseguir la libertad intelectual y moral apropiándose del castellano y desarrollándolo con características que traducen la especificidad de las condiciones sociohistóricas de la realidad del país. Así, para crear una literatura nacional moderna, propuso modificar tanto la ortografía como el contenido cognoscitivo del castellano. Los escritos de González Prada se caracterizan por el empleo de vocablos exactos y rítmicos, particularmente en su libro póstumo Trozos de vida (París, 1933). Su prosa está influida por la burla de Quevedo, la frescura de Voltaire y el entusiasmo de Rousseau. Sus oraciones gráficas sintetizan un pensamiento atrevido y un contagioso estado emocional. Con frecuencia las metáforas reemplazan los adjetivos y los adverbios. Por otro lado, sus símiles, onomatopeyas, alegorías, alusiones y otras figuras retóricas, enriquecidas por elegancia musical, no sacrifican la sinceridad, la claridad y la precisión del contenido. Como Baudelaire, siguiendo a los impresionistas, don Manuel cultivó la sinestesia. Por todas estas innovaciones, poco a poco se convirtió en una personalidad literaria de relieve continental, y en un gran divulgador de las ideas prevalentes en las letras francesas y alemanas. Conforme pasaron los años, su ars poetica se perfeccionó y satisfizo a sus admiradores. Con respecto a Pájinas libres, Miguel de Unamuno observó: «Es uno de los pocos, de los muy pocos libros latinoamericanos, que he leído más de una vez; y uno de los pocos, de los poquísimos, de los cuales tengo un recuerdo vivo»" ${ }^{3}$.

Debemos recordar que, después de retornar de Europa, González Prada se acercó al proletariado y publicó nuevos ensayos progresistas hasta convertirse en uno de los exponentes más importantes del pensamiento radical hispanoamericano. En 1908, publicó Horas de lucha, su segundo libro en prosa sobre la realidad nacional. En esta colección destacan «Los partidos y la Unión Nacional», «Nuestro periodismo», «Nuestros conservadores», «Nuestros liberales». "Nuestros magistrados», «Nuestros legisladores», «Nuestra aristocracia» $\mathrm{y}$ otros ensayos que radiografían la sociedad peruana ${ }^{4}$. Con metáforas cargadas de ironía y sarcasmo, critica implacablemente las instituciones del país, valiéndose de la hipérbole.

González Prada estuvo convencido de encontrarse en el umbral de una gran transformación histórica nacional, en el inicio de la revolución, en la cual lo viejo y lo nuevo colisionan en circunstancias en que las glorias del pasado sirven de lanzas para forjar el futuro. En esta coyuntura, el escrito cumple su misión de propaganda y ataque. Cuando se critica a don Manuel por hacer de la literatura una tribuna de propaganda y ataque, no se han tenido en cuenta las circunstancias históricas que condicionaron el sentido social a sus escritos. Nuestro autor solía enfrentarse al desafío histórico con apasionamiento y elocuencia. A despecho de esos críticos, en su mayoría peruanos, la influencia continental de

\footnotetext{
3 Cfr. Unamuno 1918: 115.

4 En la segunda edición póstuma editada por su esposa, Horas de lucha incluye «Nuestros indios», ensayo inconcluso originalmente escrito en 1904, considerado el mejor de sus textos indigenistas.
} 
Manuel González Prada ha sido reconocida por muchos prominentes hombres de letras de países hermanos. Rufino Blanco Fombona (1874-1944) lo consideró como uno de los cinco grandes escritores latinoamericanos. Miguel de Unamuno sostuvo que había muy pocos autores americanos y no americanos que conmovieran más a sus lectores que González Prada, «incansable forjador de metáforas [...] que escribe a estocadas retóricas».

\section{Aportaciones políticas}

Además de su influencia literaria, González Prada también marcó profundamente la política peruana. Su pensamiento ha influido en la redacción de programas para modernizar y democratizar el país. Su aversión a las limitaciones y prejuicios sociales, al colonialismo estético y a la sociedad retrógrada lo empujó fuera del ámbito propiamente literario y a producir una literatura política sobre los males del país y la transformación social. Su defensa de los desamparados del mundo le ganó adeptos y admiradores en muchas partes. Durante la Guerra Civil española, iniciada en 1936, los obreros de Barcelona publicaron Anarquía, el libro revolucionario de González Prada. En América, desde Buenos Aires hasta Nueva York, su nombre se convirtió en bandera de protesta antiimperialista.

No obstante la exasperación causada por la apatía de muchos intelectuales y obreros, González Prada se mantuvo optimista, confiado en que sus discípulos serían testigos y partícipes de la revolución. González Prada compartió con Victor Hugo el objetivo literario de destruir para construir, sublevar el espíritu nuevo contra el espíritu viejo y convertir la república literaria en campo de batalla. Su discurso comparativo y metafórico ilumina el discurrir de su lógica para estimular simpatía y exaltar tanto el consciente como el subconsciente del lector. Para recalcar, recurre a la hipérbole, la exclamación, la letra cursiva o subrayada y los dos puntos. Cuando la circunstancia lo exige, utiliza neologismos, diminutivos, indigenismos y americanismos. Otras veces, acude a los escritores del Siglo de Oro, particularmente a Quevedo. Estructurados con uno o dos párrafos introductorios, sus ensayos continúan con varios apartados en los que desarrolla su tesis con un párrafo de conclusiones. Casi todos los apartados terminan en una oración sentenciosa que remata la idea central. Los periodos finales, en forma de aforismos o apóstrofes, conllevan la intención de crear imágenes cargadas de insinuaciones persuasivas, como «La lectura debe proporcionar el goce d'entender, no el suplicio de adivinar ${ }^{5}$. Al evocar sabrosas anécdotas, el prosista entretiene y divierte al lector, que, desde las primeras páginas, admira la valentía, las metáforas y la concisión del autor.

En Pájinas libres, González Prada resalta como idealista imaginativo, apóstol perfeccionista, predicador ético y sembrador de ideas. Su inclaudicable oposición a los

5 Cfr. González Prada 1985: 255. 
déspotas le hizo a veces excederse en la denuncia, no obstante su permanente esfuerzo para afirmar y negar respaldándose en la verdad. Para don Manuel, la ciencia es la nueva religión.

Siguiendo el ejemplo de Andrés Bello y Domingo Faustino Sarmiento, en el «Discurso en el Ateneo» y «Notas sobre el idioma», don Manuel discrepó de la ortografía oficial y propuso el uso del apóstrofe, las contracciones clásicas del, della y desa, el uso de la vocal $i$ en vez de la conjunción $y$, la sustitución de la $g$ por la $j$ delante de las vocales $e$ e $i$, y otras reformas.

Escritor cuidadoso y exigente, Prada publicó en vida solo parte de su prosa; el resto, como su poesía, vio la luz tras su muerte o permanece inédito en la Biblioteca Nacional del Perú. Entre las obras publicadas por su hijo Alfredo, destaca Nuevas pájinas libres, impresa en Santiago de Chile en 1937, con una «Advertencia del editor». Dividida igualmente en cinco partes, la obra contiene quince ensayos y seis prólogos a diferentes libros de escritores amigos. La calidad estética del gran escritor se confirma en esta publicación.

La prosa combativa y la persistente rebeldía de González Prada le ganaron admiradores pero también detractores, incapaces de entender su espíritu de sacrificio y amplio amor a la humanidad y a la naturaleza. Sin embargo, teniendo en cuenta solo las ideas innovadoras de Pájinas libres, críticos y admiradores valoran a su autor como un gran escritor latinoamericano, un iniciador del movimiento renovador de las letras y las ideas en el continente.

Es difícil encasillar el estilo de este autor en una escuela específica. Se caracteriza por cierto eclecticismo literario y una fuerte inclinación a la renovación expresiva. Encaja más en el modernismo que en cualquier otro movimiento, pero no cultiva el exotismo ni el arte por el arte. Su fuerza radica en el armonioso equilibrio de ideas atrevidas y expresión sencilla y convincente. Del romanticismo heredó la rebelión contra las reglas. Su prosa, pacientemente elaborada, exuda la agresividad del propagandista ideológico acostumbrado a alternar sencillez y claridad estilísticas con ironía sorpresiva. En sus ensayos históricos, sociológicos y filosóficos, la prosa es más sustantiva e ingeniosa, rica en figuras literarias que intentan suavizar la mordacidad. El ensayista inventa, transforma y recrea un lenguaje literario que sirve de vehículo eficaz y veloz a las ideas. En este sentido, el lenguaje se transforma en prolongación del ideario y los sentimientos.

En «Propaganda y ataque», «Notas acerca del idioma» y otros ensayos, el autor dejó recomendaciones para lograr una prosa original, vigorosa, correcta, armoniosa, exacta, plástica, y, sobre todo, propia. Para alcanzar un estilo directo se debe — según él— emplear un léxico que no remita al lector constantemente al diccionario. Admira la prosa de Voltaire, por ser «natural como un movimiento respiratorio, clara como un alcohol 
rectificado» ${ }^{6}$. Le preocupa tanto la originalidad, utilidad y novedad de las ideas, como el aspecto estético de la presentación. Por esforzarse en encerrar el mayor número de ideas en el menor número de palabras, su prosa es sumamente sustanciosa. Las oraciones son breves y coherentes, adornadas con giros sintácticos que animan y dan variedad al lenguaje. Muestran destreza en el correcto uso de los verbos, sustantivos y adjetivos y revelan las posibilidades caracterizadoras de los adjetivos para obtener plasticidad y sugerencia.

González Prada intentó ser a la vez ecuménico y local. Se esforzó por interpretar al peruano y lo peruano como parte de su esfuerzo de identificación continental. Su espíritu innovador no se riñe ni con el clasicismo ni con la erudición internacional. Eso sí, adapta siempre las ideas foráneas, clásicas o modernas, a la realidad americana. Del liberalismo positivista evolucionó al anarquismo. De la literatura objetiva y social, impregnada de cientificismo y regida por el ideario del progreso, llegó a la literatura de propaganda y ataque a favor de la creación de una sociedad ácrata. En resumen, por su innovadora literatura política, tan rica en ideas, justamente se le ha llamado a Manuel González Prada un adelantado del pensamiento contestatario, un «precursor del nuevo Perú», un «heraldo de la revolución».

\section{Bibliografía}

GONZÁLEZ PRADA, Adriana de (1947). Mi Manuel. Lima: Editorial Cultura Antártica.

GONZÁLEZ PRADA, Manuel (1894). Pájinas libres. París: Paul Dupont. Incluido en Manuel González Prada (1985), Obras, volumen 1, Luis Alberto Sánchez editor. Lima: Ediciones Copé (PetroPerú). (1901). Minúsculas. Lima: Adriana y Alfredo González Prada editores. (1991). Exóticas. Lima: El Lucero.

(1908). Horas de lucha, primera edición. Lima: El Progreso Literario; (1924) segunda edición, Callao: Lux. Incluido en Manuel González Prada (1986), Obras, volumen 3, Luis Alberto Sánchez editor, Lima: Ediciones Copé (PetroPerú).

(1933). Bajo el oprobio. París: Luis Alberto Sánchez editor. Incluido en Manuel González Prada (1986), Obras, volumen 2, Luis Alberto Sánchez editor, Lima: Ediciones Copé (PetroPerú).

(1933). Trozos de vida, Alfredo González Prada editor. París: Louis Bellenand.

(1935). Baladas peruanas, Alfredo González Prada editor, prólogo de Luis Alberto Sánchez. Santiago de Chile: Ercilla.

(1936). Anarquía. Santiago de Chile: Editorial Ercilla. Incluido en Manuel González Prada (1986), Obras, volumen 3, Luis Alberto Sánchez editor, Lima: Ediciones Copé (PetroPerú).

6 Cfr. González Prada 1946: 259. 
(1937). Nuevas pájinas libres, Alfredo González Prada editor. Santiago de Chile: Ediciones de Ercilla. Incluido en Manuel González Prada (1985), Obras, volumen 1, Luis Alberto Sánchez editor, Lima: Ediciones Copé (PetroPerú).

(1939). Propaganda y ataque, Alfredo González Prada editor. Buenos Aires: Ediciones Imán. Incluido en Manuel González Prada (1985), Obras, volumen 4, Luis Alberto Sánchez editor, Lima: Ediciones Copé (PetroPerú).

(1941). Prosa menuda, Alfredo González Prada editor, Buenos Aires: Ediciones Imán. Incluido en Manuel González Prada (1986), Obras, volumen 4, Luis Alberto Sánchez editor, Lima: Ediciones Copé (PetroPerú).

(1945). El tonel de Diógenes, seguido de Fragmentaria y Memoranda, introducción de Luis Alberto Sánchez, Alfredo González Prada editor. México D. F.: Edición Tesontle (Fondo de Cultura Popular). Incluido en Manuel González Prada (1986), Obras, volumen 2, Luis Alberto Sánchez editor, Lima: Ediciones Copé (PetroPerú).

(1977). Ortometría, apuntes para una rítmica. Lima: Universidad Nacional Mayor de San Marcos.

(2001). Textos inéditos de Manuel González Prada, Isabelle Tauzin Castellanos editora. Lima: Fondo Editorial de la Biblioteca Nacional del Perú.

HAYA DE LA TORRE, Víctor Raúl (1927). «Mis recuerdos de González Prada», pp. 84-85. En: revista Repertorio Americano, 13 de agosto de 1927.

MARIÁTEGUI, José Carlos (1928). 7 ensayos de interpretación de la realidad peruana, Obras completas, volumen 2. Lima: Amauta, 1959.

Revista Social, nro. 72, 1 de noviembre de 1886.

Revista Social, nro. 120, 8 de noviembre de 1887.

UNAMUNO, Miguel de (1918). Ensayos, tomo VII. Madrid: Publicaciones de la Residencia de Estudiantes. 


\section{Francisco García Calderón \\ (1883-1953)}

Osmar GonZales Alvarado 

Francisco García Calderón es uno de los intelectuales fundamentales del Perú. Perteneció a la generación fundadora con la cual empezó el siglo XX, la llamada generación arielista o generación del Novecientos. García Calderón fue el más cosmopolita y latinoamericanista de todos sus compañeros generacionales, entre los que destacan pensadores como Víctor Andrés Belaunde, José de la Riva-Agüero, José Gálvez y el hermano de Francisco, el escritor Ventura García Calderón, para mencionar a los más destacados. Estos jóvenes intelectuales posteriores a la guerra del Pacífico tuvieron como objetivo pensar y llevar adelante la «regeneración nacional».

En general, Francisco García Calderón y los miembros de su grupo generacional han sufrido una especie de olvido y no han sido tomados en cuenta en el momento de evaluar el pensamiento político peruano. Esta marginación ha tenido una doble vertiente: por un lado, herederos ideológicos perezosos y, por el otro, adversarios políticos sectarios. Solo desde hace pocos años — dos décadas aproximadamente— las obras de García Calderón, y las de los arielistas en su conjunto, han gozado de reimpresiones de sus textos fundamentales.

Por las razones antes dichas, esta es una buena oportunidad para subsanar en parte el silencio al que ha sido sometido García Calderón para conocer su biografía y relevar la calidad de su obra tanto como la profundidad de su pensamiento. Estas páginas tienen la intención de familiarizar a las nuevas generaciones con nuestros pensadores clásicos.

\section{BiograFíA}

Paradójicamente, Francisco, hijo del presidente que defendió el territorio patrio, no nació en el Perú, sino en Chile, más exactamente en Valparaíso, en 1883. Su padre fue el llamado presidente de La Magdalena, Francisco García Calderón Landa ${ }^{7}$ Él, que en un primer momento fue impuesto por las fuerzas de ocupación chilenas en 1881, durante la guerra del

7 Francisco García Calderón Landa (1834-1905) también fue un intelectual de prestigio. Publicó una obra trascendental, Diccionario de legislación peruana, que para el historiador Jorge Basadre constituye una visión panorámica del país, antecedente inmediato de El Perú contemporáneo. En el siglo XIX integró la Revista de Lima, que dirigía Manuel Pardo, el fundador del Partido Civil, y que se caracterizaba por ofrecer una mirada moderna a los temas nacionales y con visión de desarrollo. Fue además rector de la Universidad de San Marcos en varias oportunidades. Destacado como fue don Francisco en las letras y en la política, no resulta extraño que sus hijos siguieran sus pasos, especialmente en los terrenos de la reflexión y la actividad intelectual. 
Pacífico, supo negarse después a firmar un tratado que despojaba al Perú de sus territorios salitreros del sur. Por ello, precisamente, fue exiliado a Chile. Terminado el conflicto bélico, la familia García Calderón-Rey se trasladó a París, en donde nació Ventura.

De retorno a Lima en 1886, junto a su familia, Francisco realizó sus estudios escolares en el Colegio Los Sagrados Corazones o La Recoleta, a pocos metros de su residencia de la calle de La Amargura, hoy jirón Camaná. Este colegio fue muy importante para la generación arielista y, en general, para gran parte de la intelectualidad peruana.

El hogar de la familia García Calderón-Rey contaba con una copiosa biblioteca. En ella, los pequeños Francisco y Ventura y sus hermanos menores (José y Juan) pudieron acercarse a las obras de autores clásicos y modernos; ahí aprendieron la sana costumbre de leer, pensar y escribir. El estímulo del ambiente del hogar fue un factor determinante en su temprana vocación.

A algunas cuadras de donde vivían los García Calderón, en la calle Lártiga, vivía quien sería el gran amigo y compañero de colegio de Francisco García Calderón hijo: José de la Riva-Agüero. En La Recoleta, García Calderón y Riva-Agüero iniciaron y fortalecieron una amistad entrañable. No puedo dejar pasar la oportunidad para llamar la atención sobre la distinta suerte que han corrido sus respetables solares: mientras la casa de los García Calderón es alquilada a pequeños comerciantes de todo tipo, la de Riva-Agüero es uno de los más importantes centros culturales de Lima.

Son múltiples los testimonios que registran las largas conversaciones que sostenían los García Calderón, Riva-Agüero y sus compañeros de generación — que se convertirían con el tiempo en destacados escritores, periodistas, diplomáticos y políticos—, en la plaza de La Recoleta o, también, en la biblioteca del ex presidente de La Magdalena. Víctor Andrés Belaunde es muy sentimental cuando recuerda esos años de juventud, cuando llegó a Lima desde su natal Arequipa, en 1900, y se vinculó estrechamente a los jóvenes que después serían considerados como los renovadores de los estudios peruanistas, siendo él mismo uno de ellos.

Terminados sus estudios escolares, García Calderón ingresó a la Facultad de Letras de la Universidad de San Marcos, en 1901. La muerte de su padre, en 1905, fue un duro golpe para el joven Francisco, quien vio que se agudizaba su esquizofrenia, e incluso en algún momento intentó suicidarse. La familia en pleno se mudó a París.

García Calderón ya había empezado a escribir sus reflexiones sobre el Perú desde muy joven, y con ellas partió a la Ciudad Luz. Francisco contaba con solo veintitrés años de edad. Así, se alejaba de la patria, de familiares y amigos, pero también de las maledicencias y envidias, como en algún momento le confesaría por carta a RivaAgüero. Desde entonces, García Calderón se convertiría en un observador agudo, pero lejano, de la vida intelectual y política del Perú. Pero vayamos con calma y conozcamos su proceso biográfico e intelectual. 


\section{La reflexión peruanista: El Perú contemporáneo}

García Calderón fue el discípulo más destacado que tuvo el maestro uruguayo José Enrique Rodó (1871-1917), autor de un opúsculo que influyó en los jóvenes intelectuales de principios del siglo XX, Ariel, que apareció en 1900. Por esta razón, García Calderón le pidió a Rodó que prologara un conjunto de sus artículos que constituyeron su primer libro, titulado De litteris, de 1904. Rodó no escatimó elogios para García Calderón, especialmente cuando afirmó: «Yo veo en él una de las mejores esperanzas de la crítica americana». No se equivocó. Al año siguiente publicó Menéndez Pidal y la cultura española.

En 1906, Francisco, su madre y sus hermanos partían a París. Fue una decisión trascendental y que rendiría grandes frutos. La experiencia europea fue fundamental para nuestro pensador, que años después se haría evidente en sus obras, las que trasuntarían un irrenunciable amor por la vida intelectual francesa, en esos momentos el faro de la cultura universal.

En París, García Calderón adquiriría aires de cosmopolitismo; quizá fue el que poseía la mirada más universal de todos sus compañeros generacionales. La capital francesa se constituiría en su mirador para analizar ya no solo los problemas peruanos sino también los de América y del mundo. Este cosmopolitismo explica por qué tan rápido dejó de escribir sobre el Perú. No fue solo porque vivía en Europa, sino, sobre todo, por la talla de intelectual que fue adquiriendo tanto por experiencias vividas como por sus insomnes lecturas. Estableciendo la comparación con las trayectorias intelectuales de sus coetáneos, observamos que en José de la Riva-Agüero o Víctor Andrés Belaunde, por ejemplo, la realidad peruana siempre estuvo presente en sus escritos.

En García Calderón se unen los sentimientos de la nostalgia y del nuevo arraigo, los recuerdos de Lima y el entusiasmo por París. La devoción que sentía García Calderón por la cultura francesa es reconocida por el prologuista de El Perú contemporáneo, el respetado profesor francés de La Sorbona Gabriel Séailles, cuando dice en el primer párrafo: «El señor García Calderón es un joven peruano que conoce admirablemente Francia, su historia, sus escritores, sus filósofos y que, sin ignorar los defectos del espíritu latino, está convencido de que sus altas virtudes de claridad, universalidad e idealismo social, deben asegurarle en el futuro un rol similar al que desempeñó en el pasado».

Fue en 1907 que García Calderón publicó en París, en lengua francesa, su gran obra, Le Pérou contemporaine (El Perú contemporáneo), de visión amplia e integral sobre los problemas nacionales, y que sirvió para hacerlo visible en la comunidad intelectual francesa. Se trata de un libro fundador del pensamiento social peruano, y se inscribe en el objetivo de renovación de los estudios peruanistas que inició la Generación del Novecientos, luego de la derrota sufrida ante Chile. 
Dada la importancia de El Perú contemporáneo, es imprescindible detenernos un momento en él para describirlo y analizarlo.

Usualmente se ha considerado a esta obra como el resultado de la intención del autor de escribir un texto de propaganda del Perú (como país que crecía y hacía abrigar las mejores esperanzas) en el público europeo. Pero, como ya mencioné, las primeras cuartillas las escribió en Lima, aunque fue en París en donde les dio la forma definitiva como libro. Augusto Ruiz Zevallos ${ }^{8}$ recuerda incluso que García Calderón pensó en publicarlo en Lima, pero la sorpresiva muerte de su padre y el consiguiente viaje a Francia fueron circunstancias que explican la edición parisina.

En cualquier caso, hay que considerar el factor tiempo, que involucra el largo proceso de redacción del manuscrito. Primero, cuando García Calderón vivía en Lima y empezó a escribir las primeras páginas de su futura obra, seguramente su público ideal era el limeño, especialmente sus amigos y colegas. Luego, cuando ya se había trasladado a París, es muy posible que hubiera modificado su imagen del lector al que quería dirigirse: ahora sería el europeo, que muy poco sabía de nuestro país.

El Perú contemporáneo es un libro lleno de optimismo, propio de la belle époque europea, y esto no deja de llamar la atención. ¿Cómo explicar que un autor que sufría de constantes ataques depresivos pudiera trazar —en páginas llenas de conocimiento y reflexión - las líneas maestras de la mirada entusiasta y esperanzada por el futuro? Más aun, se convirtió en el símbolo de una época que terminaría con el estallido de la Gran Guerra (1914-1918).

A pesar de la lucidez y erudición que revelan las páginas de El Perú contemporáneo, esta obra capital de la conciencia peruanista no se instaló en la tradición intelectual nacional, sino muy tarde y parcialmente. Apenas una pequeña élite de intelectuales y amigos del autor lo leyeron y lo incorporaron en sus reflexiones y discusiones. Solo en 1954, es decir, cuarenta y siete años después de haber sido publicado, Jorge Basadre traduce y publica el capítulo final y más importante de El Perú contemporáneo, titulado «El porvenir»" En 1981, gracias a la iniciativa de Luis Alberto Sánchez e Ismael Pinto el libro se tradujo completamente y fue editado por Interbanc. Finalmente, esta traducción fue reimpresa en 2001 por el Fondo Editorial del Congreso de la República del Perú como parte de las Obras escogidas (que incluyen La creación de un continente y Las democracias latinas de América $)^{10}$. En conclusión, una obra fundamental que solo cuenta con dos ediciones en el Perú. Esto nos habla del olvido y la ingratitud con los que castigamos a nuestras más

8 Cfr. Ruiz Zevallos 2007.

9 Jorge Basadre reproduce el referido capítulo en la compilación que hizo de algunos textos de Francisco García Calderón, titulada En torno al Perú y América.

10 Complementariamente, el propio Congreso organizó, en 2001, un coloquio en el que se divulgó la figura y la obra de García Calderón, en una iniciativa realmente inusual y encomiástica. 
importantes referencias intelectuales ${ }^{11}$. Como señala Ruiz Zevallos: «Otro habría sido el destino de Francisco si no se hubiera visto obligado a migrar a Europa y otra la repercusión de El Perú contemporáneo. Su permanencia en Lima habría enriquecido el debate intelectual en nuestro medio...» ${ }^{12}$.

Como contraparte al olvido peruano, García Calderón se afianzó como una figura intelectual en Francia. En el mismo año 1907 obtuvo el Premio Fabien de la Academia Francesa.

En El Perú contemporáneo García Calderón ofrece una lectura cabal del país ubicado ya en las coordenadas del positivismo en auge. Si bien en un primer momento heredó la visión idealista de Rodó, prontamente tomó distancias de él ${ }^{13}$. Fue su más importante discípulo, es cierto, pero su lealtad intelectual no le impidió marcar distancias críticas de su maestro ${ }^{14}$. Sin embargo, es justo decir que El Perú contemporáneo es una expresión de tránsito intelectual del autor, que cobija tanto claves idealistas como positivistas. En realidad, su desencanto con el idealismo y con Henri Bergson ocurre a partir de 1913, como precisa David Sobrevilla ${ }^{15}$.

Desde las primeras líneas de la «Introducción» de El Perú contemporáneo, García Calderón permite reconocer su mirador: «El nombre de América ya no tiene el mismo significado que antes. Hoy se aplica especialmente a Estados Unidos, crisol de la civilización occidental y potencia mundial por su riqueza e imperialismo». Estas palabras trasuntan un sentimiento ambiguo frente a la potencia del norte: admiración por su progreso evidente, pero también distanciamiento crítico, sobre todo cuando más adelante afirma: «Hay otra América más joven que la del norte, y que ofrece otras características de tradición y raza». Esto es arielismo puro; ya Rodó había ofrecido un tipo de lectura así, tanto en Ariel como en El mirador de Próspero. Pero en las palabras de García Calderón también destaca su manera de calificar a Estados Unidos como imperialista. Obviamente no tiene el mismo significado leninista, pero sí alude a la expansión económica de dicho país. Dos años antes, en 1905, Riva-Agüero, en su Carácter de la literatura del Perú independiente, llamaba la atención sobre el vasallaje económico que Estados Unidos podía imponer; había, pues, conciencia del peligro que representaba para la independencia y autonomía de nuestro país.

11 Cfr. Gonzales 1996. Una visión más amplia de García Calderón y su generación la ofrezco en Sanchos fracasados. Los arielistas y el pensamiento político peruano.

12 Cfr. Ruiz Zevallos 2007.

13 Javier Mariátegui tiene la siguiente acertada afirmación: «García Calderón fue el arielista por antonomasia. A la muerte de Rodó quedó como el más calificado de sus discípulos sin ser 'un imitador servil de Rodó', como recuerda atinadamente Karen Sanders. Comparte, a nuestro juicio, con Honorio Delgado, el título honroso de idealistas en el estilo del pensador uruguayo». Cfr. Mariátegui 2001-2003.

14 Cfr. Gonzales 2001-2003.

15 Cfr. Sobrevilla 2001-2003. 
En páginas posteriores, muy en las huellas dejadas por Montesquieu en El espíritu de las leyes, García Calderón establece una relación inversa entre naturaleza y civilización: «De la costa a la sierra y de la sierra a la montaña, la cultura se debilita y pierde y, en la misma dirección, de oeste a este, la naturaleza, primero pobre y seca, se torna cada vez más bella, hasta la montaña, extremadamente fecunda». En otro momento establece la tensión entre el centralismo total de Lima y la variedad «de razas», que permite mantener la debilidad de las provincias. Aunque es verdad que no tiene una visión muy elogiosa de la raza indígena (vengativa, monótona, sin voluntad, etcétera), ofrece algunas explicaciones sobre sus orígenes históricos valiéndose de la literatura más actualizada de su tiempo.

En el capítulo I, «El renacimiento peruano», García Calderón parte de las razones que explican la guerra con Chile, buscando una reflexión equilibrada y descargada de pasiones. Pero lo que más le preocupa es que las heridas que han quedado luego del conflicto obstaculizan el sueño integracionista de Bolívar. Para el autor, la unidad de Hispanoamérica era una necesidad imperiosa para defendernos de «una invasión anglosajona o contra la tutela política de Estados Unidos». ¡Qué mirada tan aguda y premonitoria la de García Calderón! Precisamente, la desunión de nuestras Repúblicas ha facilitado el tutelaje o intromisión de Estados Unidos. Si alguien afirma que era un pensador antinacional está muy equivocado. Por otra parte, es curioso constatar que, mientras nuestras Repúblicas nacieron cobijadas por las ideas de la integración, en Europa se buscaba justamente consolidar los Estados nacionales en desarrollo; ahora, casi dos siglos después, la América Latina que añoraba la unión sigue desmembrada y Europa acelera sus pasos integracionistas.

Más allá de los problemas mencionados, lo que García Calderón busca enfatizar es el progreso peruano luego del conflicto de 1879: «El Perú ha pasado por una transformación rápida y explosiva. Es una República que se afirma en la paz, un Estado que se enriquece y engrandece, un país que renace». Esta es la base del optimismo que nuestro autor tiene en el porvenir.

En el capítulo II, «La evolución de las ideas y de los hechos en el Perú republicano», el arielista peruano esboza un recorrido histórico desde la Conquista y la Colonia, observando especialmente el desenvolvimiento de las instituciones como la Inquisición y el propio Estado, por ejemplo, que tenían el común denominador de anular la individualidad de los sujetos. Luego llegó la revolución de la independencia, que fue precedida por un inusitado movimiento de ideas mediante el cual se fue justificando la separación de España, abriendo una nueva etapa en el proceso nacional. La gran influencia que encuentra García Calderón en la Revolución latinoamericana es la Revolución francesa.

Posteriormente, para entender el desenvolvimiento del Perú republicano, el autor se detiene para analizar el proceso político desde el mirador de las leyes y el desarrollo constitucional; critica el militarismo y la concepción tradicionalista que predomina en la 
actividad económica. Luego, afirma que «el alma nacional no está formada todavía». Por un lado, nos recuerda a Riva-Agüero, quien en 1905 decía que el alma nacional existe aunque está aletargada; pero también nos evoca a Mariátegui, que dos décadas después sostendría que el Perú es una «nacionalidad en formación». Finalmente, García Calderón cierra el capítulo con un balance nada promisorio: «Rol primario de la inteligencia; debilidad de la voluntad y triunfo del personalismo; culto al decoro en el estilo y en la vida; plutocracia depresiva y deprimente».

En el capítulo III, «Las fuerzas económicas actuales», nuestro personaje explica las razones de su optimismo, pues constata que diferentes rubros de la economía peruana muestran cifras en ascenso, en franco progreso. Si bien tenemos, afirma, riqueza, fuente virgen, tierra fecunda, subsuelo inagotable, lo que le falta al Perú es capital humano y financiero, técnica y ciencia. País minero y agrícola, supera todas las expectativas; pero las debilidades pueden ser suplidas por los capitales extranjeros y la técnica moderna. No se puede negar que se presiente en las palabras de García Calderón el discurso que caracterizaría al aprismo algunas décadas después.

En el capítulo IV, «Las fuerzas políticas», el "profesor de idealismo» peruano afirma algo que no nos suena muy ajeno cuando dice que la política: «Sirve de decoración a la vida. Se es político por curiosidad de espíritu, en un libre juego de las facultades intelectuales [...]. Hacemos política por hacerla». Evidentemente, García Calderón habla en un tiempo de escasa profesionalización de la política, pero que lamentablemente se parece mucho a lo que sucede en la actualidad. De igual talante desazonado es la frase que suelta sobre el Parlamento: «Obediente a las sugerencias de la autoridad [...], nunca ha sido una fuerza real de equilibrio político y social».

También se preocupa García Calderón por presentar un esquema de los principales partidos políticos peruanos, centrándose en el Civil y en el Demócrata. Especialmente considerado es con Nicolás de Piérola, líder del Partido Demócrata, y el gobierno que instaura en 1895 luego de derrocar al general Andrés A. Cáceres. Para García Calderón, este es un momento fundador del Perú moderno: «Expuso los fundamentos de un nuevo periodo".

En el capítulo V, «Las fuerzas educativas», García Calderón empieza mencionando la influencia que tiene la religión católica en la enseñanza nacional, y también en la formación de la mujer, a la que vuelve en conservadora. Pero no deja de mencionar que, igualmente, el clero tiene en sus manos la educación de las élites, lo que considera peligroso para la formación del carácter del peruano, «ya que favorece, por su acción, todos los vicios hereditarios: a la pereza intelectual, responde con soluciones dadas, con afirmaciones sin crítica y su condena al análisis; a la debilidad de la voluntad, con la disciplina universal y la dirección minuciosa y autoritaria de la conciencia». Pero, en el otro extremo de los grupos sociales, igualmente la influencia católica ha sido "poco fecunda sobre el pueblo», 
con algunas excepciones, como las misiones religiosas del convento de Ocopa, ejerciendo una influencia benéfica sobre el indígena.

En cuanto a la educación estrictamente hablando, el autor señala que ha sido memorística, enciclopédica, favoreciendo «las inclinaciones viciosas del país: la vanidad, la retórica, la improvisación sin disciplina ni esfuerzo». Por otra parte, la universidad es anticuada, pasadista; «solo brinda una instrucción incipiente y primitiva». Sin embargo, García Calderón es optimista por el cambio que, según observa, se produce gracias al impulso de las nuevas generaciones, especialmente de la suya propia, la de principios del siglo XX. A la universidad se suman la prensa, la opinión y la imitación (influencia de Hipólito Taine). El ideal de García Calderón es que la educación se constituya en una fuerza de progreso, que redunde en el bien material de la sociedad. Parecidos planteamientos encontraremos en Manuel Vicente Villarán y, después, en Mariátegui.

En el capítulo VI, «La situación internacional», García Calderón analiza la diplomacia peruana y los conflictos limítrofes del Perú con, en primer lugar, Chile, y luego con Ecuador, Colombia, Bolivia y Brasil. Para ello, hace gala de sus profundos conocimientos históricos e, incluso, de derecho internacional. Sería otro intelectual de su generación quien tendría a su cargo la sustentación de las razones de la posición peruana: me refiero a Víctor Andrés Belaunde, quien, desde el Archivo de Límites y de diferentes representaciones en nombre del Estado, echaría las bases de la diplomacia peruana. Con respecto a los problemas derivados de la guerra del Pacífico, García Calderón urge en la aplicación del Tratado de Ancón para que Tacna y Arica regresen a la jurisdicción nacional: «El Perú solo exige el cumplimiento de un pacto histórico». Este es el tema pendiente de nuestra diplomacia que atañe no solo a formales cuestiones limítrofes sino que incluyen elementos de historia, tradición y dignidad nacionales, sostiene García Calderón. Sobre los temas pendientes con los otros países mencionados, se muestra optimista, pues considera que están en vías de solución, la que llegaría en el tiempo de Augusto B. Leguía.

En el capítulo VII y final, «El porvenir», García Calderón concentra lo mejor de sus sentimientos y reflexiones para sostener el esbozo de lo que denomina «el destino de la nacionalidad peruana». En él se percibe con claridad la perspectiva positivista que ya ha asumido nuestro personaje: «Quisiéramos destacar, por medio de este capítulo y de este libro — dice-, una conclusión. Es fácil y simple. El Perú es un país de porvenir, cuyo pasado es interesante, inquieto y a veces trágico y soberbio. Es una nueva nacionalidad que se organiza en el orden y la paz».

García Calderón analiza con prudencia y equilibrio la doctrina Monroe, pues, si bien no es un antiyanqui militante, tampoco descuida la posibilidad del peligroso tutelaje político; define a los países de Europa como envejecidos, alienta la inmigración de las que supone son «razas superiores» (europeas, se entiende), describe — con muchos prejuicios, es verdad, pero que no son solo de él sino de muchos intelectuales de su época- las psi- 
cologías de las «razas de color» (indígena, asiática, negra, selvática), que componen el mosaico nacional, y propone el mestizaje que elimine las herencias retardatarias; es insistente en la necesidad de industrializar nuestra economía y fortalecer la clase media o burguesía nacional, entre muchas otras consideraciones que hacen de El Perú contemporáneo un libro magnífico por su sentido integral, conocimientos, reflexión y, algo que no es banal, la utilización de la buena escritura.

La forma de escritura en García Calderón es importante, pues El Perú contemporáneo también es un conjunto de ensayos: prosa limpia, frases breves, ideas e intuiciones ofrecidas con claridad y sencillez. Todas estas características hacen de este libro una obra definitivamente inserta en la tradición moderna, que luego sería tomado como ejemplo por las nuevas generaciones, especialmente por Mariátegui.

Mirando en conjunto El Perú contemporáneo, se advierte que el autor traza su propia línea de pensamiento. Como vimos, sus primeras palabras están cargadas del mensaje de Rodó, que rechaza el materialismo burdo de Estados Unidos para realzar la espiritualidad de nuestros países. Pero, para el final de su libro, García Calderón ya ha hecho suyas las claves positivistas de orden y progreso. En ellas reposa su optimismo y la confianza en que las reformas que propone (al Estado, a las costumbres, al sistema político, etcétera) colocarían al Perú en el lugar prominente en América Latina que nunca debió perder.

La visión total de El Perú contemporáneo precede y empalma, como en diferentes oportunidades lo ha manifestado Jorge Basadre, con 7 ensayos de interpretación de la realidad peruana, de José Carlos Mariátegui. Si en El Perú contemporáneo el lector puede percibir rápidamente el sentido integral que su autor quiso imprimir a sus páginas, de igual modo, dos décadas después, en 1928, Mariátegui, joven también — con treinta y cuatro años de edad-, publicaría sus 7 ensayos de interpretación de la realidad peruana, obra que se constituiría en la más importante de nuestro pensamiento social, también llena de un sentido de totalidad y de intenso compromiso humanista.

Mariátegui y García Calderón tienen algunos rasgos comunes que los aproximan. Un rasgo es que se trata de dos autores precoces; otro es la admiración por la cultura francesa; otro más, la predilección del ensayo como vínculo de comunicación; uno más, la atenta mirada que cada uno dirigió a la realidad mundial, y, finalmente, la precisión de la prosa que reflejaba el cuidado y coherencia en la exposición de las ideas.

\section{LA MIRADA DESDE EL EXILIO. LA CULTURA Y LA POLÍTICA}

Como hemos visto, desde muy joven, García Calderón — junto a su familia— vivió en el exilio. Se trató de una migración voluntaria, no impuesta, ni como consecuencia de alguna persecución política. Fue una manera de alejarse de los problemas del entorno inmediato y para tratar de aliviar el dolor que le causó la partida de su padre. No le fue fácil 
adaptarse a la sociedad parisina en un primer momento, pero luego se volvió en uno de sus personajes más caracterizados, especialmente para los latinoamericanos que visitaban la Ciudad Luz, centro de la cultura occidental de ese entonces. A pesar de la comodidad que halló en París, no dejó de tener presente a su país. Este sentimiento de pertenencia a lo lejos se puede percibir con claridad en la nutrida correspondencia que cursó con su gran amigo, Riva-Agüero.

En París, García Calderón reafirma su vocación intelectual. Esta es evidente por su angustia de no ser totalmente libre para expresar sus opiniones, pues cumplía, desde 1910, funciones de segundo secretario en la legación peruana en París, es decir, era parte del Estado peruano. Pero, al mismo tiempo, no deseaba volver aún al Perú porque no tenía independencia económica. No es cierto, por tanto, que fuera un hombre opulento, como algunas veces se ha dicho tratando de desvirtuar su voluntad de vivir en el extranjero, como si hubiera buscado el desarraigo y el afrancesamiento; en todo caso, reitero, fue un cosmopolita. Desde el exilio siempre tuvo en mente a su país: tanto es así que murió en su querida Lima. El exilio de García Calderón es una experiencia recorrida por muchos compatriotas, desde el Inca Garcilaso de la Vega hasta Mario Vargas Llosa. Es parte del proceso vivido por muchos pensadores.

Por otro lado, la residencia en París de García Calderón le permitía comunicarse con los más altos representantes de la cultura occidental, a la cual buscó integrarse con éxito. La mejor demostración de lo dicho es que Francisco, junto a su hermano Ventura, fueron propuestos por los grandes personajes de la cultura francesa de la década de 1940 como candidatos al Premio Nobel de Literatura. No es poca cosa.

Desde su residencia parisina, García Calderón impulsó y dirigió la Revista de América (1912-1914), en la cual escribieron los intelectuales latinoamericanos más representativos de aquellos años previos al conflicto europeo.

En dicha revista colaboraron escritores destacados, como Rubén Darío, Enrique Gómez Carrillo, Amado Nervo, Rufino Blanco Bombona, José Ingenieros, Hugo Barbagelata, Alfonso Reyes y Alcides Arguedas, entre otros. Esta publicación dejó de ser editada en 1914, cuando estalló la Gran Guerra. Había terminado la belle époque europea y se avecinaba una dura etapa de confrontaciones y barbarie. En 1917, los bolcheviques derrocaron al zarismo en Rusia y un modelo de civilización (el occidental) tocaba sus límites; los intelectuales, por ello, ingresaban en una etapa de profundas reflexiones, tratando de reinterpretar el nuevo mundo que se abría ante sus ojos.

García Calderón buscaba la verdad y sus afirmaciones expresaban lo que honestamente creía. Complementariamente, no era un intelectual radical, un cuestionador implacable del poder. Lo que buscaba, como gran parte de su generación de principios del siglo XX, era contribuir a realizar las reformas que consideraba necesarias para acercar el Estado a la sociedad. En ese sentido, no apelaba a las masas — eso correspondería a las genera- 
ciones posteriores - , sino a la aristocracia de la inteligencia, aun cuando ello supusiera la conformación de gobiernos fuertes o autoritarios. Por ello, no es de extrañar que un personaje relevado por García Calderón fuera el dictador mexicano Porfirio Díaz, quien se mantuvo en el poder durante más de tres décadas. Finalmente, tampoco le interesó ingresar a los terrenos pantanosos de la lucha política. Observó el proceso político desde su mirador de intelectual. No se involucró en las pasiones que dividen a las sociedades. A lo más, se atrevía a dar consejos a su querido amigo de la infancia, Riva-Agüero, cuando este pretendía asumir —o asumía de hecho— cargos públicos importantes.

A pesar de que fue muchas veces tentado para integrarse a las pasiones políticas, García Calderón siempre tuvo la firme decisión de no involucrarse en ellas. Incluso, no faltaron quienes lo quisieron enfrentar a Riva-Agüero en las lides políticas. García Calderón rechazó tajantemente toda posibilidad de traicionar a su amigo; la generosa amistad prevaleció sobre las ambiciones personales. Ejemplo que es bueno seguir.

\section{LA FECUNDA OBRA}

Luego de publicar El Perú contemporáneo, la producción intelectual de García Calderón siguió siendo intensa. En 1907 sacó a la luz, en Valencia, Hombres e ideas de nuestro tiempo, con prólogo de Émile Boutroux; en 1908, publicó su folleto «Las corrientes filosóficas en América Latina» (traducida del alemán por el filósofo dominicano Pedro Henríquez Ureña), y en 1909, Profesores de idealismo, en París. Así, a su reflexión peruanista le agregó preocupaciones sociológicas y filosóficas. Paralelamente, colabora en diarios de La Habana (Diario de la Marina) y Buenos Aires (Le Figaro).

La obra de García Calderón fue ampliando sus horizontes paulatinamente; del mirar al Perú pasó a interpretar la realidad del continente. De esta manera, publica, en 1912, Las democracias latinas de América y, en 1913, La creación de un continente, los dos libros en París. Con estos trabajos, García Calderón se convirtió en una referencia ineludible para entender los temas americanos o, más precisamente, latinoamericanos; incluso ambos fueron traducidos a los idiomas más importantes de su tiempo y en las universidades europeas los cursos latinoamericanistas les tenían un lugar asegurado en sus bibliografías. El entonces joven escritor mexicano Alfonso Reyes, admirador del pensador peruano, lo denominó, con toda justicia, «docteur ès Amérique Latine».

En 1916, publica su ensayo «El panamericanismo: su pasado y su porvenir». Al año siguiente sufre otra terrible pérdida. Su hermano José muere en el campo de Verdún, a manos de las fuerzas alemanas. En 1917, publica Ideologías, en París. La integración de García Calderón en la vida francesa se revela con su nombramiento en la Legión de Honor de Francia. En 1919, en Madrid, aparece Ideas e impresiones. También El dilema de la Gran Guerra, tanto en castellano como en francés. Siguiendo con su función diplo- 
mática, se traslada a Bélgica como ministro plenipotenciario del Perú hasta 1921, cuando renuncia. Luego, como miembro de la delegación en Europa, fue el encargado de reunir la documentación para sustentar la posición peruana sobre la cuestión de Tacna y Arica. En el mismo año, 1920, publica un trabajo central en su larga obra, El wilsonismo, en el que exhibe un conocimiento cabal del mundo de su tiempo. En 1926, recopila nuevos artículos sobre la política occidental con el nombre de Europa inquieta, que se publica en Madrid. En 1928 aparece El espiritu de la nueva Alemania, en Barcelona. Al año siguiente publica La herencia de Lenin y otros artículos, en París.

En 1930, García Calderón vuelve a asumir un cargo diplomático, esta vez como ministro plenipotenciario del Perú en Francia, cargo que ocuparía por diez años. En 1938 preside la Sesión 103 del Consejo de la Sociedad de Naciones. En ese mismo año publica su última compilación, titulada Testimonios y comentarios, en Bruselas, compuesta de artículos publicados en Buenos Aires y Lima. En 1942, vive otra experiencia traumática. Él y un grupo de diplomáticos latinoamericanos son detenidos por las autoridades nazis. Su débil salud mental sufre un grave daño. Lo ronda nuevamente la idea del suicidio. En 1944, sufre otra pérdida. Esta vez la muerte de su gran amigo, Riva-Agüero. En Ginebra publica un folleto en su homenaje: «In memóriam», repaso por momentos desmesurados de su compañero y de la vida peruana. En 1947, regresa al Perú, pero ya está sumamente enfermo. Al año siguiente es internado en la casa de salud Víctor Larco Herrera. Aun así, en 1949 da a conocer su último folleto, titulado José de la Riva-Agüero. Recuerdos, en Lima.

Había señalado que la posición económica de García Calderón no era holgada. Por esa razón, el Congreso decidió aumentar su jubilación de diplomático. Finalmente, el 1 de julio de 1953 fallece en Lima, a la edad de setenta años, y sin dejar descendencia.

La larga y fecunda obra de García Calderón lo llevó rápidamente de ser discípulo de Rodó a maestro de las nuevas generaciones. Mantuvo la confianza en la juventud y en la llamada "aristocracia de la inteligencia» expuesta en Ariel, pero se distanciaba en su antinorteamericanismo. Paulatinamente, fue matizando sus convicciones espiritualistas para asumir las proposiciones positivistas. Partiendo de los temas peruanistas, adquirió un vuelo intelectual universal. Unió en sus escritos sus amplios conocimientos de historia, filosofía y sociología. Pocos como él mostraron esa envergadura de pensador humanista.

\section{Bibliografía}

GARCÍA CALDERÓN, Francisco (1954). En torno al Perú y América. Lima: Juan Mejía Baca \& P. L. Villanueva.

GONZALES, Osmar (1996). «Las formas del olvido. La correspondencia entre Francisco García Calderón y José de la Riva-Agüero». En: Riva-Agüero en sus cartas. Lima: Ediciones El Laberinto. 
(1996). Sanchos fracasados. Los arielistas y el pensamiento politico peruano. Lima: Ediciones Preal.

(2001-2003). «Francisco García Calderón: un modelo de intelectual». En: Acta Herediana, segunda época, volumen doble 30-31, de abril de 2001 a marzo de 2003.

MARIÁTEGUI, Javier (2001-2003). «Francisco García Calderón y la tradición socialista», Acta Herediana, segunda época, volumen doble 30-31, de abril de 2001 a marzo de 2003.

RUIZ ZEVALLOS, Augusto (2007). «El Perú contemporáneo». En: suplemento «El Dominical», diario El Comercio. Lima: 27 de julio de 2007.

SOBREVILLA, David (2001-2003). «Francisco García Calderón y la filosofía». En: Acta Herediana, segunda época, volumen doble 30-31, de abril de 2001 a marzo de 2003. 



\section{Víctor Andrés Belaunde \\ (1883-1966)}

\section{Diego García-SaYán}



Por generación y por convicción, del pensamiento político peruano fundacional del siglo XX había conocido y estudiado ante todo los trabajos de José Carlos Mariátegui y de Víctor Raúl Haya de la Torre. Le dediqué menos atención —o, para ser más preciso, mucho menos- a Víctor Andrés Belaunde en mis lecturas y reflexiones políticas universitarias.

Pasados los años y «nivelado» el debate político en su punto más mínimo, la aridez hoy prevaleciente no parecía ser el mejor entorno para recurrir así, en abstracto, a los «clásicos». La invitación para contribuir a este volumen ha sido una excelente ocasión, que agradezco, para un tardío pero particularmente útil acercamiento a Belaunde, constatando la multiplicidad y riqueza de sus aportes. Lamentablemente estos han sido insuficientemente aprovechados en los variados proyectos políticos germinados a lo largo del siglo XX y que muchas veces fueron simplificados o arrojados al rincón prejuiciado de lo «conservador» $\mathrm{y}$ «reaccionario», sin mayor análisis ni conocimiento. No se trata, tampoco, de que ahora haya descubierto que Belaunde era una especie de «socialdemócrata» encubierto o de que hubiera adherido a sus planteamientos si los hubiera conocido a tiempo. Pero sí la riqueza y profundidad de su análisis.

No habría podido organizar estas ideas de no haber tenido la suerte de contar con el tiempo generoso de varias personas estimables que me dieron su perspectiva, compartieron su experiencia o me alcanzaron alguna idea o reflexión interesante. Para este propósito me fue particularmente ilustrativo conversar con el doctor Luis Bedoya Reyes, quien tiene una muy rica y vívida visión sobre lo que fue y significó Belaunde para nuestro siglo $\mathrm{XX}, \mathrm{y}$ — como es de suponer- en la formulación del pensamiento social cristiano en el Perú, del cual Bedoya es singular y relevante exponente. Alberto Adrianzén me alcanzó interesantes ideas y compartió generosamente conmigo algunos «incunables», imposibles de encontrar en librerías. De particular valía fue la conversación con Domingo García Belaunde, nieto y último secretario personal de Víctor Andrés, facilitada por su hermano Víctor Andrés, quien también me proporcionó insumos importantes.

El propósito de estas páginas no es efectuar un análisis exhaustivo de las muy variadas contribuciones intelectuales de Víctor Andrés Belaunde. Tan ambicioso objetivo va más allá de lo que en estas pocas páginas se puede poner en blanco y negro. El propósito —-más acotado y modesto — es resaltar lo que considero son sus reflexiones y planteamientos de 
mayor relevancia para el curso de los debates y del accionar político durante el siglo XX. No es el área de la filosofía una de mis especialidades, de manera que no me adentro en lo que fueron las reflexiones y aportes de Belaunde en esa materia. Tampoco analizo aquí lo que fue el inmenso aporte de Belaunde en materia diplomática y de derecho internacional. Me concentro, más, en lo que tiene que ver directamente con la dimensión y el impacto político de tan ilustre peruano.

\section{Propuesta de país y ausencia de proyecto político}

Si bien José Carlos Mariátegui y Víctor Raúl Haya de la Torre fueron pensadores que conectaron de manera directa sus reflexiones y análisis con la organización y la conducción política en el siglo XX, ese no fue el caso de Víctor Andrés Belaunde. Calificado por muchos como conservador y motejado — injustamente- por algunos como fascista, Belaunde tuvo un significado muy importante en el análisis y pensamiento político del Perú en el siglo XX. El trabajo que Osmar Gonzales le dedica al núcleo intelectual conocido como «arielista», del cual era parte Belaunde, lleva el sintomático título de Sanchos fracasados ${ }^{16}$, aludiendo con ello a que, paradójicamente, sus ideas y planteamientos no se transformaron en proyectos políticos concretos y exitosos.

En efecto, una de las grandes paradojas del pensamiento político de Belaunde es que no se tradujo en un proyecto político estructurado en torno a lo que era, objetivamente hablando, minucioso análisis de la realidad peruana y multidimensional propuesta de país. Cuando concluyó su discurso en la Universidad de San Marcos en $1914^{17}$ afirmó en contundente y claro llamado «Queremos patria!», condensando, así, lo que era en esencia perspectiva y propuesta de futuro. Eso no se trasladó luego, sin embargo, a una propuesta política viable. Gran paradoja de la política nacional en el atormentado siglo XX. Pensamiento estructurado en torno a la "política» en su sentido lato pero desconectado de lo que Bedoya Reyes califica como «política concreta».

Y eso durante toda su trayectoria. Sea porque los pocos proyectos de «política concreta» en los que se involucró no fueron particularmente exitosos; sea porque él mismo tomó distancia frente a posibles espacios de acción que se le abrían (la convocatoria de Riva-Agüero, por ejemplo, para participar en los gobiernos de Sánchez Cerro o Benavides); o porque, finalmente, no fue convocado cuando esperó serlo (por ejemplo, durante el gobierno de Bustamante y Rivero). Más allá del espacio de la política nacional (breve desempeño como ministro de Relaciones en 1958), los espacios en ámbitos universitarios le fueron también esquivos. Las circunstancias y la polarización política le cerraron el paso al rectorado de San Marcos. En la propia Universidad Católica no

\footnotetext{
16 Cfr. Gonzales 1996.

17 Cfr. Belaunde 1914.
} 
llegó a ser rector pese a que, eso sí, fue decano, vicerrector y, al final, rector emérito. Confirmando el dicho de que «nadie es profeta en su propia tierra», la función pública de mayor relevancia que desempeñó no fue en el Perú, sino como presidente de la Asamblea General de las Naciones Unidas en 1959.

Dentro del país podría pensarse que el proyecto de la revista Mercurio Peruano fue el de concreción orgánica más sostenida, consistente y de mayor impacto de su trayectoria académico-política. Los vaivenes de la política de esos tiempos atravesaron, como es lógico, el curso de dicha publicación. Estando ausente durante la década de 1920 por el exilio, varios miembros del consejo de redacción (Mariano Iberico, Alberto Ureta y Alberto Ulloa) cuestionaron el excesivo peso de los temas religiosos y la cercanía de Belaunde con grupos religiosos conservadores. Estas diferencias llevaron al apartamiento de los cuestionantes. Por diferencias de signo contrario, Riva-Agüero se alejó por las tendencias «bastante izquierdistas» de la publicación ${ }^{18}$.

El proyecto más notorio de "política concreta» en el que estuvo directa y activamente involucrado fue el de la formación del Partido Nacional Democrático, en el que José de la Riva-Agüero tuvo protagonismo especial, pues fue quien fundó la agrupación en 1915. Su participación en las elecciones de ese año les fue adversa (Belaunde fue candidato a diputado por Arequipa, sin éxito). Viendo que no les era directamente «instrumental», los grupos de poder económico de ese entonces dejaron al Partido Nacional Democrático sin piso.

Parecía que lo que los grupos oligárquicos buscaban eran instrumentos operacionales muy directos y funcionales, y no proyectos políticos más amplios en los que la proyección de hegemonía política de los mismos suponía sacrificios y renunciamientos inmediatos en aras de una representación más amplia. Otra vez la ceguera de no ver a la vuelta de la esquina ni más allá de la nariz. En lapidaria y precisa aseveración, Gonzales ha dicho que: «Los grupos oligárquicos prefirieron la ganancia particular y el acomodo institucional de acuerdo con las circunstancias, aunque con éxito, pues de otra manera no se puede explicar su larga permanencia en el poder. Mirar al futuro suponía tener una conciencia de país y una convicción modernizadora de las que carecieron dichos grupos privilegiados» ${ }^{19}$.

Años después fue elegido en 1931 como diputado por Arequipa al Congreso Constituyente. Ya que estaba finalizando su exilio no efectuó una campaña electoral, por lo que la elección es particularmente meritoria. En el Congreso Constituyente, como dice Bedoya Reyes, «conquista [...] espacio privilegiado en la Cámara ${ }^{20}$ con sus reflexiones

18 Cfr. Belaunde 1914: 141.

19 Cfr. Gonzales 2008.

20 Cfr. Bedoya Reyes 2007. 
y propuestas sobre diversos temas el «mensaje social cristiano» ${ }^{21}$. En efecto, si bien se opuso al voto de los analfabetos y de los militares, defiende el voto femenino y la libertad de prensa.

\section{Calidad de los debates y PROPUesta de país}

Hay dos aspectos que creo importante destacar en lo que es el estilo y la proyección política del pensamiento de Belaunde. Primero, la calidad de los debates en los que participó. Segundo, el que sus reflexiones y planteamientos tuvieran como norte un proyecto de país que se situaba mucho más allá de urgencias coyunturales o propósitos electoreros.

En efecto, tuvo bastante que ver el estilo firme pero respetuoso de Belaunde frente a sus adversarios con la calidad de muchos de los debates en los que participó. Osmar Gonzales ha destacado con precisión ${ }^{22}$ cómo, en los primeros treinta años del siglo XX, la propuesta socialista levantada por José Carlos Mariátegui tenía, sin duda, en Haya de la Torre su referente más intenso de polémica y confrontación. Pero la tenía, en profundidad, con la llamada «intelectualidad del Novecientos», dentro de la cual Belaunde era un componente fundamental. En el fragor del debate, por cierto, no estaba ausente la crítica mordaz, pero el mismo Mariátegui reconocía la importancia intelectual de Belaunde y ambos discutían con altura.

Destaca, notablemente, el debate de Belaunde con Mariátegui a propósito de los 7 ensayos de interpretación de la realidad peruana. Belaunde confrontó este libro, a través de artículos publicados en su revista, en Mercurio Peruano, que luego dieron forma al libro La realidad nacional. En sus textos reconoció aportes y aspectos positivos, y puso de relieve, como era su legítimo derecho, aquello en lo que discrepaba y el sustento para ello. Con corrección, Pedro Planas, en su artículo «La polémica frustrada», destacó que el debate entre Belaunde y Mariátegui fue la «verdadera polémica sobre el país». Este debate, sin embargo, se cortó abruptamente por la temprana muerte del segundo.

No he encontrado en las líneas de Víctor Andrés Belaunde el uso de descalificaciones o adjetivaciones contra sus adversarios, sino un conjunto de ideas o planteamientos, con los que se puede coincidir o discrepar, pero que eran ingredientes sólidos para los debates sustantivos en los que participó. Con razón Luis Bedoya Reyes dice que «siempre fue respetuoso frente a discrepantes $»^{23}$, en referencia expresa a su elogio a Mariátegui. ¡Cuánto ayudaría al curso político del Perú que aunque fuese algunos de estos rasgos sobreviviesen hoy en día en el país! El debate político parece haber sido reducido, en el presente, a sinónimo de oferta electoral o de invectiva al adversario.

21 Cfr. Bedoya Reyes 2007.

22 Cfr. Gonzales 2007.

23 Cfr. Bedoya Reyes 2007. 
El continente — las formas — de un debate alturado era posible, sin embargo, no solo por calidades personales, sino por algo aun más importante, que era la existencia de ideas articuladas en torno a un proyecto de país. Había cosas que decir. Y muchas. Es verdad de Perogrullo que Mariátegui y Haya tuvieron un papel protagónico en ese terreno. Pero como las ideas de Belaunde no se plasmaron en un proyecto político con su participación o bajo su conducción, se olvida a veces que su análisis abarcador de la realidad nacional se iba traduciendo en una propuesta de país estructurada, no como una letanía de utopías, sino de planteamientos concretos en temas como la regionalización, el sistema electoral y la organización del Estado además, naturalmente, de lo que atañe al derecho internacional y, particularmente, a los límites del Perú.

\section{El pensamiento de Belaunde}

La lógica de análisis de Belaunde parte de principios generales que aplica a su examen de la realidad nacional. Esos principios generales se estructuran en torno a la filosofía (particularmente el pensamiento cristiano), el derecho, la sociología y la historia ${ }^{24}$. Su concepto de la nación y la nacionalidad tiene un carácter absoluto por la vigencia «universal e intemporal $\aleph^{25}$ de conceptos que parten de la noción europea de nación (que había surgido de un proceso específico y definido en esa región del mundo), tratando de ver cómo la realidad del Perú coincidía con los mismos.

En ese marco conceptual, Belaunde es un analista crítico de la realidad desde sus tempranos aportes, como los conceptos vertidos en su discurso en San Marcos, «La crisis presente» (1914). En esa ocasión, denunció la crisis económica, el desbarajuste constitucional con un Poder Ejecutivo que ejercía poderes omnímodos, el caciquismo parlamentario y el fraude electoral. Puso de manifiesto problemas profundos de la sociedad peruana, como la injusticia con la población indígena y el abandono de las provincias. Muy distinto de la complacencia del «conservadurismo» contemporáneo.

En su análisis de la determinación de las nacionalidades, el territorio desempeña un papel fundamental. Por ello su énfasis en la vocación nacional de la unidad territorial y la ocupación del territorio plasmada en la cultura incaica de los andenes y caminos, reforzada por el centralismo virreinal y la obra de la República. En esa misma perspectiva nace su aproximación a la región amazónica como parte de la peruanidad, y el estudio de los procesos limítrofes en esas zonas tan alejadas y desconocidas en esos tiempos.

Durante los primeros años del siglo, Belaunde desempeñó funciones en el Archivo de Límites del Ministerio de Relaciones Exteriores, en donde empezó su carrera diplomática en 1903. Entre otros jefes del Archivo de Límites, bajo cuya responsabilidad trabajó,

24 Cfr. Llosa 1962: 144.

25 Cfr. Llosa 1962: 145. 
estuvo Carlos Larrabure y Correa, mi abuelo materno, quien, entre otras decisiones, comisionó a Belaunde para buscar, reunir y sistematizar la documentación que Víctor M. Maúrtua necesitaba para la defensa peruana en el arbitraje para delimitar la zona fluvial con Bolivia, para lo cual se había designado al presidente de Argentina. El laudo arbitral posterior confirmó, en líneas generales, la tesis peruana y Bolivia lo aceptó. Cuando Larrabure y Correa pasó a desempeñar otras funciones, Belaunde lo reemplazó como jefe del Archivo de Límites.

Su oposición posterior a Leguía tuvo que ver no solo con el carácter autoritario y caudillesco de su gobierno, sino con otros asuntos, en particular con el manejo por el régimen del asunto colombiano y por la entrega a Colombia del denominado «Trapecio Amazónico» a través del Tratado Salomón-Lozano de 1922. En la exposición de la Sociedad Geográfica y del Instituto Histórico sobre la cuestión de Leticia que Belaunde redactó, se afirma con contundencia que: «Puede decirse sin exageración que el Tratado Salomón-Lozano, al extender artificialmente el territorio de Colombia al trapecio del Putumayo y el Amazonas, atentó profundamente contra la autonomía y el desarrollo económico y la seguridad militar del Oriente peruano» ${ }^{26}$. Destacó que el Perú con ello perdía su control de la entrada al río Amazonas, «siendo Tabatinga puerto brasilero y cedido, al frente, el puesto de Leticia ${ }^{27}$.

\section{ASPECTOS MÁS RELEVANTES}

Hay cinco aspectos que me parece relevante destacar del pensamiento político y trayectoria de Belaunde. Muchos otros de enorme importancia, por cierto, quedan de lado en este ensayo (por ejemplo, su análisis de la historia, sus estudios filosóficos o religiosos y los múltiples aportes en materia diplomática y de derecho internacional).

Estos cinco aspectos son: su compromiso con los principios democráticos, el papel de la religión en el proceso político, las reformas sociales y el pensamiento conservador, la regionalización y el tema indígena.

\section{COMPROMISO CON LOS PRINCIPIOS DEMOCRÁTICOS}

Si bien Belaunde no fue un "político», en el sentido de dedicación de su tiempo y energías a la actividad política pública, hubo momentos de su vida en los que sí participó activamente en política. En ese tipo de circunstancias se puso de manifiesto su identificación con los principios democráticos y su reticencia frente a actos y procesos autoritarios. $\mathrm{Y}$ eso en varios ámbitos. Así, por ejemplo, tempranamente (1908) se expresó a favor de la

26 Citado por José Pareja Paz Soldán. Cfr. Pareja Paz Soldán 1968: 96-97.

27 Cfr. Belaunde 1987: 207. 
participación de los estudiantes en los consejos directivos de las universidades, posición que mantuvo a lo largo de su vida, en contraste, a la del autodefinido «reaccionario» Riva-Agüero. En efecto, cuando concurrió al Primer Congreso de Estudiantes, que se llevó a cabo en Montevideo en 1908, sostuvo esta tesis.

En 1921, a los pocos años de haber fundado Mercurio Peruano (1918), fue deportado por el régimen autoritario de Leguía por oponerse al régimen y a la expropiación ese año del diario La Prensa, y por defender en acto público a Luis Fernán Cisneros y a otros encarcelados por el gobierno. Permaneció en el exilio hasta 1930.

Ya en las elecciones presidenciales de 1931 se había expresado, junto con otros de su generación, a favor de una "tercera opción», distinta de la polaridad que planteaban las candidaturas de Sánchez Cerro, por un lado, y de Haya de la Torre, por el otro. El propio Belaunde fue propuesto como opción por Manuel Vicente Villarán y finalmente lanzaron la candidatura inviable de De la Jara. Sobre esas elecciones señaló que «los elementos culturales y las masas neutras estuvieron prácticamente al margen de la contienda. El gobierno derechista de Sánchez Cerro cometió el error de no iniciarse con un gabinete de concertación nacional. El sector de oposición izquierdista cometió otro gran error: no aceptó su rol de oposición gubernamental, sino pretendió realizar una labor de oposición revolucionaria $»^{28}$.

En las simultáneas elecciones a la Asamblea Constituyente, Belaunde fue elegido integrante de la misma. Luego de que los diputados apristas fueran apresados y deportados por el régimen de Sánchez Cerro en febrero de 1932, se retiró de la Asamblea y viajó fuera del país. Su posición de rechazo y protesta fue firme y clara, no solo con su conducta, sino con sus palabras: «Se mutiló la Asamblea Constituyente con la prisión y desafuero de veintitrés diputados apristas. El Parlamento quedó mediatizado, la libertad de imprenta suprimida y suspendidas indefinidamente las garantías individuales ${ }^{29}$. Se reincorporó a la Constituyente en las postrimerías de la misma, a instancias del arzobispo de Lima, para defender la posición de la Iglesia católica en temas como la religión católica como rectora espiritual del Perú y en asuntos como el matrimonio y la familia.

Frente a los regímenes autoritarios de Sánchez Cerro y Benavides, a diferencia de Riva-Agüero, mantuvo una actitud distante viendo con recelo, por ejemplo, el proyecto de alianza entre los civilistas y el militarismo del sanchezcerrismo y, luego, la dictadura de Benavides. Dentro de los múltiples aportes de Osmar Gonzales sobre esta parte de la vida política de Belaunde, destaca las reflexiones y documentación sobre la conducta de Belaunde frente a las convocatorias de Riva-Agüero para enrolarlo con Sánchez Cerro o Benavides (de quien Riva-Agüero fuera ministro de Estado).

28 BELAUNDE, Víctor Andrés. Balance político, «Epílogo», citado por José Pareja Paz Soldán. Cfr. Pareja Paz Soldán 1968: 67.

29 Cfr. Pareja Paz Soldán 1968: 67. 
Así, cuando Riva-Agüero lo convoca a colaborar con el régimen de Sánchez Cerro, Belaunde le responde sacando a relucir su férrea oposición al caudillismo sin contrapesos ni control señalándole a su interlocutor: «Esto equivale a entregar a su suerte a un ciego o unirse al destino de un loco. Toda cooperación con Sánchez Cerro que no se traduzca en el control del gabinete me parece suicida ${ }^{30}$. Como dice bien Gonzales, con estas líneas Belaunde «no hace otra cosa que ser coherente con sus reflexiones anteriores y que vienen desde su primera madurez $»^{31}$, sobre el peligro de la falta de contrapeso al poder presidencial. Añade Gonzales que «se trataba de un escrupuloso republicano. Fue consecuente con un perfil de intelectual que —aun con una filiación ideológica clara, el socialcristianismo, y de sus definitivas demarcaciones con el marxismo y el aprismo- no dejó que sus convicciones fueran vulneradas por las urgencias de la lucha política ${ }^{32}$. Por estas razones, suponer que Belaunde fue un pensador que apoyó al fascismo en el Perú es un tremendo error.

\section{LA RELIGIÓN}

El tema religioso es muy importante en el pensamiento de Belaunde. Si bien algunos de sus exegetas y supuestos seguidores se anclan exclusivamente en lo que en ello hay de énfasis en el tradicionalismo y en la importancia de lo trascendente en el desarrollo del individuo, la aproximación de Belaunde es mucho más amplia y se proyecta en lo que Sinesio López califica como un pensamiento "profundamente sociológico» ${ }^{33}$.

Así, pues, parte de la perspectiva de lo trascendente pero ubicándola como norte e inspiración de procesos sociales y políticos. De acuerdo con la perspectiva de muchos, es en esa vertebración que se encuentra la raíz del pensamiento socialcristiano en el Perú. Estamos pues, ante una aproximación a lo religioso no como espiritualidad desligada de la realidad sino como elemento inspirador para la afirmación de la nacionalidad y el destino del hombre en la realidad concreta.

\section{El REFormismo y EL PENSAMIENTo CONSERVAdor de BELAUNDE}

Si en la actualidad la calificación de "conservador» en el pensamiento político alude, esencialmente, a una propuesta de preservación del statu quo, en el caso de Belaunde hacer tal reducción sería injusto e incorrecto. Pues si bien la calificación de «conservador» en el pensamiento de Belaunde es válida, ella lo es, ante todo, por estructurar sus reflexiones en

30 Cfr. Gonzales 2007.

31 Cfr. Gonzales 2007.

32 Cfr. Gonzales 2007.

33 Cfr. López 1987: 154. 
conceptos fundamentales como la tradición y en una lectura de la vida y la sociedad sustentada en un catolicismo también conservador. Sin embargo, ello va de la mano con una visión que articula esta aproximación conservadora con una aguda crítica de los grandes males del país y afirmando la necesidad y urgencia de reformas sociales.

No es, pues, el pensamiento de Belaunde — a diferencia de los «conservadores» contemporáneos - uno linealmente instrumental de élites o de grupos plutocráticos. Por el contrario, Belaunde fue crítico de la realidad social e institucional y llamó a la reforma social. Recurrentemente identificó los tres grandes males de la República en la plutocracia costeña, la burocracia militar y el caciquismo parlamentario. Y, en base a ello, a la necesidad de reformas sociales y políticas.

La injusticia social y el arcaico sistema político estuvieron presentes como referentes fundamentales de contraste en el pensamiento de Belaunde para proponer reformas sociales como respuesta. Su perspectiva fue nutrida por la doctrina social de la Iglesia católica, cuya primera concreción se había dado en la encíclica Rerum novarum, dictada por el papa León XIII en 1891, y que tuvo su siguiente hito en la encíclica Quadragesimo anno, dictada por Pío XI en 1931.

Sin embargo, todo indica que el sustento doctrinario que más impacto tuvo en Belaunde como sustento de derecho natural para la reforma social fue el Código social. Esbozo de una sintesis católica, conocido como Código social de Malinas, escrito en 1920 por el cardenal belga Désiré Joseph Mercier. Dicho instrumento doctrinario hacía particular incidencia en las garantías sociales de los trabajadores y la población frente a los excesos de minorías privilegiadas. Buscaba explícitamente, además, conciliar el derecho de propiedad con el interés común, concepción a la que adhirió Belaunde. En el artículo 96 del Código social de Malinas se establecía que «En la medida que la necesidad lo reclama, la autoridad pública tiene el derecho, inspirándose en el bien común, de determinar a la luz de la ley natural y Divina, el uso que los propietarios pueden o no hacer de sus bienes». En crítica al «liberalismo manchesteriano», que inclinaba la balanza a favor del capital y al principio de que de que «todo producto, deducción hecha de lo que exigen la amortización y reconstitución del capital, pertenece de pleno derecho a los trabajadores», en el artículo 93 del Código social de Malinas se establece: «Es muy importante atribuir a cada cual lo que le pertenece y regular según las exigencias del bien, común, la distribución de los recursos de este mundo».

Muchos han visto — con razón- que en el anclaje del Código social de Malinas al pensamiento nacional a través de Víctor Andrés Belaunde se encuentra la raíz del pensamiento social cristiano peruano. Luis Bedoya Reyes ha señalado que cuando Belaunde polemiza con Mariátegui desde Europa, de 1929 a 1931, y, posteriormente, en la posición que expresa en la Asamblea Constituyente de 1931, era "ya un hombre [...] nutrido 
de ese pensamiento ${ }^{34}$. Basándose en ellos es que, según Bedoya Reyes, Belaunde plantea el fortalecimiento del sindicalismo no solo de los trabajadores sino de los empresarios, la participación de los trabajadores en las utilidades y en el accionarado de la empresa. «Conservadores» de otros tiempos.

\section{LA REGIONALIZACIÓN}

En la primera parte de La realidad nacional, en el acápite «En torno a los 7 ensayos, de José Carlos Mariátegui», Belaunde expresó con claridad sus coincidencias y diferencias con Mariátegui. Partiendo de reconocer en Mariátegui las «mejores cualidades de observador y de realista» y su «estilo preciso, ágil $\aleph^{35}$, puso de manifiesto sus coincidencias en aspectos esenciales: el anacronismo del debate centro-federal, la unión del centralismo con el caciquismo y la dificultad de establecer una justa diferenciación geográfica en regiones en el Perú.

En coherencia con su planteamiento de que la nación peruana es una síntesis, cuestiona a Mariátegui por su «tendencioso empeño en acentuar los contrastes geográficos y raciales, en destacar una irreductible dualidad de elementos ${ }^{36}$. A la dualidad de razas y de lenguas, Belaunde opone una idea de unidad nacional sobre la que destaca que «la oposición entre la costa y la sierra no es tan radical como Mariátegui la pinta» ${ }^{37}$ y señala, con corrección, que «al elemento indígena hay que verlo, no solo en los aborígenes puros, sino en el alto porcentaje de sangre indígena de la costa, y [...] [considerar] al factor español y al mestizo de la sierra ${ }^{38}$. A partir de ello, frente al regionalismo indigenista de Mariátegui, alcanza su propuesta de lo que se podría llamar «regionalización económica» en nueve regiones, que se sustenta en «superar las dualidades de sierra y costa, de sur y de norte» ${ }^{39}$, planteando que el proceso histórico de los «organismos vivos» (ciudades e intendencias) sea completado o modificado por «los factores económicos de la época presente» ${ }^{40}$.

\section{EL TEMA INDÍGENA}

La problemática indígena estuvo presente de manera singular y transversal en la obra y pensamiento de Belaunde. No tanto en la lógica de la multietnicidad que hoy guía la estructuración de Estados democráticos como el español, sino en una visión y perspectiva

\footnotetext{
34 Cfr. Bedoya Reyes 2007.

35 Cfr. Belaunde 2007: 207.

36 Cfr. Belaunde 2007: 210.

37 Cfr. Belaunde 2007: 211.

38 Cfr. Belaunde 2007: 212.

39 Cfr. Belaunde 2007: 216.

40 Cfr. Belaunde 2007: 219.
} 
«integradora», que en muchos aspectos se ubica en las antípodas. Vista en su momento, sin embargo, la relevancia dada a la población indígena, en una perspectiva reformista, contrastaba con el racismo excluyente prevaleciente en aquellos tiempos en las élites, particularmente en la costeña y limeña.

Belaunde enfatiza el concepto de «síntesis» como resultante del proceso de conquista y colonización. Jorge Guillermo Llosa precisa, sin embargo, que esa transformación no fue horizontal sino impuesta, dependiente y en función de los intereses de la metrópoli ${ }^{41}$. Destaca, también, cómo el pueblo indígena fue obligado a abandonar su hábitat natural para nutrir el trabajo en las labores mineras, abandonándose, así, los cultivos tradicionales adaptados a las necesidades de los habitantes y a las características del territorio. La destrucción de canales, caminos, terrazas y la red de obras de ingeniería prehispánicas supuso el sometimiento de los indígenas a condiciones oprobiosas.

En efecto, Belaunde habla de «asimilación de la raza indígena». Así dicho ello, sin embargo, no da cuenta precisa de una propuesta que, si bien era, en efecto, «integradora», no lo era sobre la base de "cooptar» simplistamente al indígena tal cual está, sino de acompañar ese proceso con cambios económicos, sociales y educativos. El hecho que propusiese un programa para potenciar la productividad de la comunidad indígena y expropiar al latifundio improductivo da cuenta que Belaunde se ubicaba en una frecuencia muy distinta de un pensamiento reaccionario que buscase dejar intocados los privilegios de ciertos grupos.

En esa concepción «integradora» hay, no obstante, un interesante señalamiento de la población indígena como parte de una sociedad mayor y no como un compartimiento estanco aislado, pues puso de manifiesto la solidaridad del indígena «con la clase media y con los obreros». Para Belaunde, la virtud principal de los 7 ensayos de interpretación de la realidad peruana, de Mariátegui, es haber otorgado un lugar prioritario al tema indígena y haber afirmado, asimismo, que su adecuada solución implica también la del problema de la tierra. Ello lo inserta en una perspectiva reformista, en la que no es ajeno un abordaje al problema de la tierra, en el que se refiere a la injusta distribución de la propiedad de la tierra en la sierra y la explotación del campesinado agrícola en la costa, proponiendo como remedio «un programa realista de reforma agraria», en una perspectiva cooperativista y de ampliación del crédito y la educación.

No obstante, no estamos precisamente ante una propuesta «indigenista» sino ante una preocupación por lo indígena que, vista desde el siglo XXI, tenía la óptica de hacer de la población indígena esencialmente un receptor —-más que un actor- de las políticas establecidas en el mundo oficial ${ }^{42}$. Para el análisis y pensamiento de Belaunde, la estructura

\footnotetext{
41 Cfr. Llosa 1962: 157.

42 Cfr. Gonzales 1996.
} 
política y el sistema electoral en las zonas andinas estaba diseñado de tal manera que lo que hacía era reproducir un sistema injusto cuestionando cómo ello había convertido al indígena en "máquinas de votación como la mesa y como el ánfora» ${ }^{43}$. No obstante, su prisma ético-religioso iba en la perspectiva de una cultura «superior» que asume a la «inferior» en la llamada "síntesis viviente " ${ }^{44}$. La cultura autóctona debía ser, pues, «asimilada» y de ella habrían de sobrevivir ante todo lo que Llosa llama los «motivos estéticos».

En esa perspectiva, por cierto, la "preocupación por lo indígena» no era retórica ni simplista. A los intentos de entender el funcionamiento del mundo andino, en lo que atañe, por ejemplo, a la contradicción entre haciendas y comunidad, añade trabajos para entender a los pueblos indígenas en la cuenca amazónica. En esa perspectiva son importantes los trabajos de Belaunde sobre los mitos amazónicos y la relación entre el Incanato y la Amazonía ${ }^{45}$.

\section{Colofón}

El aporte de Belaunde para entender mejor el Perú ha sido y es muy importante. El país —y todos dentro de él— se habría beneficiado mucho si, aunque fuera parte de sus análisis y propuestas, se hubieran incorporado más centralmente en los debates o se hubieran utilizado para tomar muchas decisiones importantes adoptadas en el país en los últimos cincuenta o sesenta años. Todavía es tiempo.

\section{Bibliografía}

BEDOYA REYES, Luis (2007). Intervención en la presentación del libro de Víctor Andrés Belaunde: Víctor Andrés Belaunde. Peruanidad, contorno y confin. Textos esenciales. Lima: Fondo Editorial del Congreso del Perú.

BELAUNDE, Víctor Andrés (1911). Los mitos amazónicos y el Imperio incaico, tesis de bachillerato. Lima: Facultad de Letras de la Universidad Mayor de San Marcos.

(1912). Las expediciones de los incas a la hoya amazónica, tesis de doctorado. Lima: Facultad de Letras de la Universidad Mayor de San Marcos.

(1914). La crisis presente.

(1987). La realidad nacional, Obras completas, tomo III. Lima: Edición de la Comisión

Nacional del Centenario de Víctor Andrés Belaunde, p. 207.

(2007). «Regionalismo y centralismo». En: Víctor Andrés Belaunde. Peruanidad, contorno

y confin. Textos esenciales. Lima: Fondo Editorial del Congreso del Perú.

GONZALES, Osmar (1996). Sanchos fracasados. Los arielistas y el pensamiento politico peruano. Lima: Ediciones Preal.

43 Cfr. Pacheco Vélez 1976.

44 Cfr. Llosa 1962: 161.

45 Cfr. Belaunde 1911. Cfr. Belaunde 1912. 
(2007). «El pensamiento peruanista de Víctor Andrés Belaunde. Estudio preliminar». En: Victor Andrés Belaunde. Peruanidad, contorno y confin. Textos esenciales. Lima: Fondo Editorial del Congreso del Perú.

(2008). «El pensamiento político peruano y Víctor Andrés Belaunde». (www.librosperuanos.com/autores/osmar-gonzales24.html). Este artículo fue publicado originalmente en la Revista de la Escuela de Posgrado de la Universidad Ricardo Palma. Lima: Universidad Ricardo Palma, vol. 4, nro. 1, diciembre de 2007.

LLOSA, Jorge Guillermo (1962). En busca del Perú. Lima: Ediciones del Sol.

LÓPEZ, Sinesio (1987). «La Generación de 1905». En: Pensamiento politico peruano. Lima: Desco.

PACHECO VÉLEZ, César (1976). «Belaunde y el indigenismo novecentista». En: diario La Prensa. Lima: 14 de diciembre.

PAREJA PAZ SOLDÁN, José (1968). El maestro Belaunde. Lima: Editorial Universitaria. 

José DE LA RIVA-AgüERo y OSMA

(1885-1944)

\section{José Agustín de la Puente Candamo}



José de la Riva-Agüero y Osma nace en Lima el 26 de febrero de 1885, en la calle de Lártiga 459, y muere el 25 de octubre de 1944, en la habitación 410 del Hotel Bolívar, en Lima. Fueron sus padres José de la Riva-Agüero y Riglos y María de los Dolores de Osma y Sancho Dávila, ambos de la aristocracia virreinal.

Fue de mediana estatura, más bien bajo, con un rostro de rasgos fuertes y definidos y con una calvicie mayor en los años finales de su vida. Esta podría ser una breve descripción de su retrato físico.

Fue intelectual y esencialmente un hombre culto, apasionado por la lectura y que desde sus días escolares demostró un conocimiento y una madurez superiores a su edad. Su memoria fue notable, pero merece mayor encomio su capacidad analítica y su actitud para comprender los temas que tenía entre manos. Su dominio de los medios de expresión, del lenguaje, lo demostraba en la conversación, en sus cartas, en sus estudios históricos. Su vocación central fue la de historiador y transitó con gran dominio por los campos de la filosofía, del derecho, de la literatura; fue un humanista.

El testimonio de Francisco García Calderón evoca la infancia de Riva-Agüero: «Juntos entramos en 1893 al Colegio de La Recoleta, destinado a larga influencia en los destinos espirituales del Perú. Él tenía ocho años y yo, diez. Eran pocos los alumnos y numerosos los profesores. De esta suerte se estableció pronto lo que llamó Platón una cadena magnética entre los discípulos y los maestros que ejercieron sobre nosotros una acción personal directa, persuasiva, formadora. Había leído mucho a Riva-Agüero, no sé cómo ni cuándo. Se le podía aplicar lo que escribió Clarín de Menéndez y Pelayo: que así como algunos duermen mientras leen, otros leen cuando duermen. Tal debió ser el caso de este muchacho que sabía de memoria páginas enteras de César Cantú, historiador italiano entonces en boga, que había leído a Michelet, repetía versos de Leopardi y se complacía en desentrañar complicadas genealogías de familias peruanas. Sorprendió pronto a sus maestros por la seguridad de sus recuerdos y el vigor de su talento. Dominaba todas las materias, salvo las matemáticas, que le fueron siempre extrañas, como a Lord Macaulay, el célebre historiador inglés. En los recreos, en vez de jugar, comentábamos nuestras lecturas. En las tardes, en paseos que no nos parecían monótonos, del colegio a mi domicilio en la calle de La Amargura, de él a esta casa de Lártiga, y de nuevo a La Amargura, en incesante y 
decidido deambular, tratábamos con juvenil petulancia de todos los problemas divinos y humanos, hacinábamos recuerdos, afirmábamos nuestras ambiciones» ${ }^{46}$.

Su personalidad fue sólida y maciza; lo que pensaba y decía lo ponía en práctica en sus hechos cotidianos y en los momentos solemnes. Su caso es un clarísimo testimonio de unidad de vida. Seguro y enfático en la afirmación de sus convicciones y enemigo de los eufemismos, expresaba su pensamiento sin equívoco alguno. Sin embargo, al lado de su firmeza intelectual estaba presente en su ánimo un espíritu de amistad y de cordialidad humana que presidía sus actos. En el zaguán de su casa de Lártiga eran numerosas las personas que recibían su apoyo material y su consejo, y entendió la amistad no como una suma transitoria de coincidencias, sino como el respeto profundo a los valores humanos de quien él consideraba amigo. Como lo recordó José Gálvez en un bello discurso el día del entierro de Riva-Agüero, tuvo un sentido espiritual y superior de la amistad. Aguerrido defensor de sus principios, polemista abrumador, no fue avaro en el uso de adjetivos, pero nunca se apartó del respeto que merece la persona humana.

La reflexión de José Gálvez sobre la amistad con Riva-Agüero es muy expresiva: «RivaAgüero tenía el raro mérito de cultivar la amistad a base de la estimación que nace de vínculos morales. Fácil es llamar compañero, amigo, camarada, a quien sigue el mismo rumbo y va por igual senda, porque, compartida esta, se hace menos larga; pero quien, como él era, a la vez, apasionado y rígido, vehemente y firme, tenaz y hasta excluyente en sus ideas, debía tener una voluntad de virtud muy grande para comprender la sinceridad, condición que sí pedía siempre de quienes no militaban en sus filas. Y es que Riva-Agüero tenía un sentido eterno y no terrenal, y por lo mismo pasajero y cambiante, de la amistad $»^{47}$.

Tuvo la virtud, que es signo de los hombres superiores, de conversar con naturalidad y paciencia, con un estudiante universitario, con un compañero de su generación o con una persona sencilla; escuchaba, corregía las expresiones indebidas en el lenguaje, precisaba la exactitud de los hechos históricos y nunca se apartaba de su ánimo de diálogo y servicio.

Perteneció a la generación del Novecientos, que convocó a los que nacieron en los días finales o posteriores a la guerra con Chile y vivió, como sus contemporáneos Belaunde, los García Calderón, José Gálvez o Julio C. Tello, una severa e intensa voluntad orientada al estudio del Perú y de lo peruano y al servicio del país a través del mejor conocimiento de su realidad y de sus exigencias. Él llegó a la política por una clara voluntad de servicio que se enriquecía, en su caso, con las calidades personales que Dios le había concedido. De él se puede decir — lo que en muchas circunstancias es un abuso del lenguaje— que llegó a la política no para lucrar con beneficios personales, sino, de verdad, para servir al país. Este fue el origen de su ingreso a la política. En él conviven el maestro universitario, el erudito y el político.

46 Cfr. García Calderón 1949: 8-9.

47 Cfr. Gálvez 1944: 667. 
El camino del conocimiento del Perú, de su formación, de su identidad, acerca a Riva-Agüero a la tarea política. Es pertinente recordar los pasos principales. Dirigente estudiantil muy respetado en San Marcos, ofreció en nombre de la juventud un homenaje a Javier Prado y en 1905, en el entierro de Francisco García Calderón, leyó el discurso en nombre de los estudiantes sanmarquinos.

Sin duda, su dedicación a la historia fue en la vida de Riva-Agüero cuestión esencial para entender su obra y su vida. Él encarnó con naturalidad y prestancia las virtudes que definen a un historiador: hombre culto, tuvo la virtud intelectual de pasar del dato erudito y seguro a la construcción más general de la interpretación de la misma; conoció desde su niñez papeles fundamentales y textos clásicos que subrayaron en su espíritu la significación de la historia en la vida del hombre y de la sociedad; encarnó en su espíritu una memoria superior que se transformó en un instrumento seguro en el desarrollo de la investigación; conoció seriamente a los clásicos latinos; igualmente, tuvo un dominio serio de la literatura peruana y de la literatura española; tuvo el fundamento intelectual necesario para desarrollar en sus estudios valiosas analogías esclarecedoras; en la intimidad de sus querencias y de sus afectos estuvo presente el Perú como síntesis de lo andino y de lo español; el tiempo de la «reconstrucción» que vivió en su infancia y juventud enriqueció su voluntad de servir al Perú; del mismo modo, su generación del Novecientos vivió con intensidad la esperanza de recuperar a las "provincias cautivas», objetivo que unió a todos los peruanos de las primeras décadas del siglo XX.

Cuando tenía veinte años, en 1905, publicó el Carácter de la literatura del Perú independiente, que fue su tesis para optar el título de bachiller en la Facultad de Letras.

Más tarde, en 1910, aparece La historia en el Perú, que, como bien dice Basadre, señala el principio de la historiografía moderna en nuestro medio.

En el mismo tiempo de la publicación de sus tesis, trabajó otros temas: José Baquijano y Carrillo, Carlos Germán Amézaga y continuó sus estudios sobre el Inca Garcilaso de la Vega y Pedro de Peralta y Barnuevo.

Además de las tesis mencionadas, los estudios sobre las conquistas incaicas, la Audiencia de Lima, el elogio del Inca Garcilaso de la Vega, es Paisajes peruanos su obra capital, en la cual propone, convencido, una suerte de retrato del Perú, fruto de la síntesis de lo andino y de lo hispánico. Escribió páginas fundamentales sobre el Virreinato y penetró en las ideas centrales de la Independencia; sus estudios sobre Santa Cruz y la Confederación Perú-Boliviana, sobre Manuel Pardo y los antecedentes de la guerra con Chile, el enaltecimiento de la persona y de la obra de Grau son algunas muestras, al lado de sus estudios sobre genealogía e historia, que integran la memoria peruana.

Los une en su generación del Novecientos una posición directiva y entiende, con sus amigos sanmarquinos, que el estudio del Perú y de lo peruano es paso fundamental para el fortalecimiento del país. 
No solo fue un erudito — la historia del Perú no encerraba ningún secreto para él一, sino que nos ha dejado una lección orientada al estudio y conocimiento de la raíz del Perú, de la formación de la nacionalidad.

«El patriotismo se alimenta y vive de la historia y de la tradición»"

«La aplicación a los estudios históricos y la reanimación por ellos de sentimiento patriótico han sido siempre donde quiera la preparación indispensable para la regeneración positiva de un pueblo, su consolidación interna y el reestablecimiento de su prestigio exterior ${ }^{49}$.

Es interesante recoger algunas afirmaciones de Riva-Agüero sobre el ser mismo del Perú: «El Perú es obra de los incas, tanto o más que de los conquistadores; y así lo inculcan, de manera tácita pero irrefragable, sus tradiciones y sus gentes, sus ruinas y su territorio». "La suerte del Perú es inseparable de la del indio; se hunde o se redime con él, pero no le es dado abandonarlo sin suicidarse». «La sierra, asiento de la gran mayoría de los habitantes, cuna de la nacionalidad, necesaria columna vertebral de su vida, tronco del cual parten las dos cuencas de tierras cálidas, tiene que ser por toda especie de razones geográficas e históricas, la región principal del Perú». «El Cusco es el corazón y el símbolo del Perú» ${ }^{50}$.

Indigenista e hispanista al mismo tiempo, creyente en el Perú mestizo, Riva-Agüero enaltece las virtudes del hombre andino y del aporte del hombre y de la cultura españoles. Insiste una y otra vez en la urgencia del estudio de la historia nacional, camino indispensable para entender el Perú.

Tal vez su bello libro Paisajes peruanos podría ser una suerte de síntesis de su conocimiento de lo peruano y de su cariño al país. La geografía, el paisaje, la historia de un lugar y otro, los sucesos históricos en un ambiente y en otro, las cuestiones sociales, todo, aparece entretejido como en una figura geométrica para explicar y entender el Perú. Su salida del Cusco, Apurímac, Huamanga y Mantaro encierran una inmensa riqueza de evocación y de esperanza.

Su ingreso a la política, a sus debates y a su lucha se produjo cuando el 29 de mayo de 1909, en manifestación pública singularísima, dirigentes del pierolismo exigieron sin éxito la renuncia del presidente Leguía. En la universidad, en reuniones públicas, en textos periodísticos Riva-Agüero asumió el liderazgo a favor de una amnistía política a los responsables de la tumultuosa exigencia de la renuncia de Leguía.

En El Comercio, el 12 se setiembre de 1911, publicó el artículo «La amnistía y el gobierno", que señala su presencia formal en nuestra vida política. Más tarde, el 25 de

48 Cfr. Riva-Agüero 1960: 5.

49 Cfr. Riva-Agüero 1960: 15.

50 Cfr. Riva-Agüero 1960: 14-15. 
setiembre y el 26 de diciembre del mismo año, y en un discurso en el centro universitario, en 1912, reitera su posición intelectual.

Basadre escribe: «La aparición política de José de la Riva-Agüero es el primer choque de los universitarios con la fuerza pública. El Senado, después de aprobar un proyecto de ley de amnistía, había reconsiderado su actitud enviando el asunto a comisión, poco antes que fuera expedida esta sentencia. Un joven catedrático, José de la Riva-Agüero, que ya había criticado públicamente en anteriores oportunidades la política internacional del gobierno, insertó el 12 de setiembre en El Comercio un vigoroso y elocuente artículo para reclamar la amnistía y censurar al estado de cosas imperantes en el país, así como los rumbos internacionales financieros e internos ${ }^{51}$.

Tal vez el momento más interesante en la vida política de Riva-Agüero es el de la creación del Partido Nacional Democrático, cuya declaración de principios es de 1915.

Algunas de las ideas principales de la nueva agrupación política podrían ser las siguientes: revivir y renovar con sangre nueva a los fatigados partidos históricos; promover la formación de grupos de opinión; «cumplir con un impostergable deber de civismo y de hombría de bien». Dice el documento fundacional: «No somos ni seremos instrumentos de nadie; no pretendemos formar una efímera organización electoral, sino un partido serio y permanente» ${ }^{52}$.

El mencionado documento habla de las garantías individuales, de las reformas constitucionales, de la reforma electoral, del Poder Judicial, del Ejército, de la hacienda pública, de fomento, de instrucción.

Encierra especial interés el desarrollo de la «cuestión social», en la declaración de principios: «Somos partidarios de la legislación obrera y de la intervención del Estado en los conflictos entre el capital y el trabajo. Es en el Perú aspecto peculiar y principalísimo de la cuestión social la desdichada condición del indio, que debe remediarse no solo con el desarrollo de las escuelas y de las vías de comunicación y con la rigurosa vigilancia sobre las autoridades subalternas políticas y judiciales, municipales y eclesiásticas, sino también con un completo y cuidadoso sistema de protección legal y auxilio gubernativo, que impida todo servicio gratuito, prohíba determinados descuentos en jornales y contenga al cabo la progresiva usurpación de las tierras de comunidades, a fin de que el indio comunero, hecho en la realidad, y no en el mero texto incumplido de la ley, dueño individual de su porción de terrenos comunes, o sindicado libre y expresamente con sus vecinos y garantizado contra los despojos y fraudes de los mestizos, no se degrade y esclavice cada día más o no acuda en lo porvenir a una desesperada y terrible sublevación rural, como la de Condorcanqui en el siglo antepasado o la de México en el momento presente» ${ }^{53}$.

51 Cfr. Basadre 1983: 332-333.

52 Cfr. Riva-Agüero 1975: 35-36.

53 Cfr. Riva-Agüero 1975: 50-51. 
En otra oportunidad, Riva-Agüero expresó que ante la situación de cansancio de los partidos tradicionales — sobre todo el demócrata y el civilista — era necesario crear un cuerpo político que asumiera la generación joven de ambos sectores y que postulara un camino de inteligencia y de honestidad que permitiera la continuidad constitucional de la República.

Es ilustrativa la reflexión de Basadre: «Algunos de los más connotados elementos jóvenes del partido demócrata, entre los que destacaban Amadeo de Piérola, José María de la Jara y Ureta y José Gálvez, se unieron en 1915 con un grupo de otras promisorias figuras en el plano intelectual y social que hubiera podido integrar una nueva generación dentro del civilismo (como José Pardo y sus colegas en 1903 y en 1904) para formar un nuevo partido, el Nacional Democrático, risueñamente apodado por Luis Fernán Cisneros 'futurista'. Lo presidió José de la Riva-Agüero, cuyo notable aporte para renovar los estudios históricos parecía acompañado por una innata aptitud directiva refrendada por el gesto de energía cívica contra el gobierno de Leguía y a favor de los acusados por la revolución del 29 de mayo de 1909. El hombre de archivo y aula parecía surgir a la vez como un ciudadano ejemplar, como personero de la conciencia de su generación, convertido en un fiscal y hasta en un guía de sus mayores» (Basadre, 1983, IX, p. 145).

En el sepelio de José María de la Jara y Ureta, el 22 de noviembre de 1935, RivaAgüero explica, con afecto por el amigo muerto, que «obedeciendo a este intento de fusión de la juventudes de los dos grandes partidos históricos, creamos el Partido Nacional Democrático [...]. Dimos ejemplo de decencia, serenidad, dignidad y civismo. En tal situación, no era presumible que nos escasearan frívolas censuras, ataques ponzoñosos, y odios solapados, o patentes y procaces. Fingieron desdeñarnos, porque nuestro círculo director, una selecta minoría, como si no ocurriera lo mismo con todos los partidos, aquí y donde quiera ${ }^{54}$.

En el mismo texto, en el cual desarrolla Riva-Agüero una suerte de confesión personal y política, dice: «Los mismos que nos habían restado fuerzas y denegado prestigio, nos acusaron luego de ineficaces, cuando el sentir de un pueblo descarriado y embaucado exige de los buenos lo inasequible e imposible, al paso que en los malos excusa o halaga los pobres y más criminales hierros. Ante la fuerza bruta, estimulada y desbordada por las culpas de nuestros propios censores, tuvimos que disolvernos, como todos los demás verdaderos y libres partidos, sin excepción alguna. Nos fuimos a la proscripción; y se quedaron mofando con vacuna risa, los que harto habían de llorar después. Muerto quedó nuestro juvenil ensueño político encuadrado en cánones de estricta pulcritud. Una algazara vil celebró nuestro fracaso, que era el del Perú; y a poco más de dos lustros, la justiciera historia, con el irresistible curso de los hechos, había convertido a todos, vencedores

54 Cfr. Riva-Agüero 1937-1938: 415-416. 
y vencidos, perseguidores y víctimas, purgadores y vejados, renovadores, restauradores y demoledores, en una colección de fracasados lastimosos $\aleph^{55}$.

Esta dura confesión de Riva-Agüero, dura y muy sentida, muestra el fin de su mayor ilusión política. El partido que él y los hombres de su generación promovieron expresó de verdad, sin apariencias, un ánimo decidido de servicio al Perú.

Esta primera etapa de la presencia de Riva-Agüero en la política nacional encierra, como lo hemos visto, dos momentos: la demanda de amnistía a los hombres que se levantaron contra el presidente Leguía en 1909 y la posterior creación del Partido Nacional Democrático. La primera actitud responde a una reacción principista frente al primer gobierno de Leguía; la creación del Partido Nacional Democrático es fruto de un esfuerzo reflexivo que lo acerque a la lucha por la conducción política del Perú.

Es frecuente el escepticismo cuando se dice que un hombre ingresa a la política con vocación de servicio; sin embargo, en el caso de Riva-Agüero, sí es verdad que su vocación política se apoyaba en la esperanza de servir al bien común de su país. Las raíces de esta actitud eran profundas y de verdad severas: su tradición familiar y una suerte de carisma directivo; su conocimiento erudito y muy serio de la historia del Perú y de sus enseñanzas; su inteligencia y su personalidad aptas para la tarea directiva; su visión seria de la vida, alejada de toda frivolidad, le advertían que quien mucho ha recibido tiene la obligación de servir con mayor generosidad. Todo lo anterior nos indica la fortaleza de las razones por las cuales ingresa a la política y que no lo alejan de su dedicación a la vida intelectual y de su cariño indeclinable a las ciencias históricas.

Fue doloroso el fracaso de su partido y su alejamiento de la política. Triste es reconocer cómo muchos no entendieron la tarea y la finalidad del nuevo grupo político que quería darle al país estabilidad política y ejemplaridad moral.

Pedro Planas, en un valioso estudio sobre la generación del Novecientos, manifiesta: «La vida pública, según los fundadores del Partido Nacional Democrático, estaba reducida 'al personalismo más estrecho, a la mera intriga, que ni siquiera suele ser ingeniosa; a una serie de tristes mezquindades; a la repetición monótona y desesperante de iguales inconsecuencias y de los mismos extravíos'. Propósito del nuevo partido es, en ese escenario político tan deprimente, establecerse, en primer término, como un 'núcleo de opinión', que reemplace 'las afinidades inconvenientes o superficiales del compañerismo y la adhesión personal' con la 'reflexiva comunidad de ideas y propósitos perdurables'. La renovación política que preconiza el Partido Nacional Democrático va más allá de la doctrina y del programa. Reside en el estilo de hacer política que debe encarnar: 'Libres todos de sombras y responsabilidades, estamos íntimamente unidos en los mismos propósitos de regeneración patria y en el mismo desdén de los prejuicios ciegos y de las ambiciones

55 Cfr. Riva-Agüero 1937-1938: 417-418. 
vulgares. No somos ni seremos instrumentos de nadie; no pretendemos formar una efímera organización electoral, sino un partido serio y permanente. La propia empresa que intentamos, con resolución inquebrantable pero no sin prever sus dificultades y sinsabores: el propósito de crear una nueva entidad política que responda a las exigencias actuales y que sin cuidarse de los provechos de hoy trabaje con los ojos fijos en el mañana del Perú, demuestre de manera irrefragable a quienquiera que no abdique de la buena fe y la razón, la absoluta pureza de nuestras intenciones y la total abnegación de nuestra conducta' ${ }^{56}$.

Carlos Rodríguez Pastor, en un muy interesante estudio sobre las ideas políticas de Riva-Agüero, dice con acierto: «Infelizmente, el Perú no pudo o no supo aprovechar, quizá cuando más lo necesitaba, de una mentalidad tan vigorosa que, a la reciedumbre de sus convicciones, unió una forma expositiva que por su elegancia y precisión pocas veces ha sido igualada ${ }^{57}$.

Más tarde, impulsado por los sucesos políticos y por la frustración de tantas esperanzas, Riva-Agüero se marchó a Europa con su madre y con su tía carnal Rosa Julia de Osma y vivió durante once años, hasta 1930, especialmente entre España, Francia e Italia.

La investigación histórica tiene que admitir sus limitaciones cuando aspira a penetrar en las razones íntimas de las decisiones humanas. Las cartas personales, la tradición oral y las memorias autobiográficas pueden aportar muchos elementos de juicio, mas, en múltiples casos, las motivaciones de un acto o de otro no pueden ser esclarecidas por la historiografía. Es el caso de su alejamiento del Perú. Él no abandonó un empeño intelectual y otro; sin embargo, se apartó por muchos años de su labor múltiple en el Perú. Es difícil decir que su alejamiento fue un error; las circunstancias lo impulsaron al viaje a Europa. Sin duda, él, más que nadie, lamentó su larga ausencia del país.

Los últimos años de su vida, de 1930 a 1944, están presididos por circunstancias políticas distintas, pero se mantiene la misma fortaleza intelectual y moral, la misma voluntad presidida por la defensa de la libertad de la persona humana y el mismo vigor y el mismo coraje moral para firmar y defender su pensamiento político y todo esto unido, como siempre, a su tarea intelectual de investigación y de enseñanza. Es abrumador por su riqueza y variedad el fichero bibliográfico de las cartas, discursos, monografías, que Riva-Agüero escribe y publica en ese tiempo.

Desempeñó múltiples funciones y fue el hombre que sin el respaldo de un partido político tuvo mayor significación e influencia en la vida del Perú de la década de 1930. En ese ambiente Riva-Agüero vivió en la intimidad de su espíritu, el regreso a la creencia en la Iglesia católica y, como buen converso, fue fiel, tenaz y perseverante en los principios que recuperó.

56 Cfr. Planas 1994: 157-158.

57 Cfr. Rodríguez Pastor 1975: XXXVIII. 
En la historia de las ideas en el Perú, el discurso de Riva-Agüero, su profesión de fe, en el almuerzo de los ex alumnos de La Recoleta, en 1932, es un documento sincero y representativo: «De mis peregrinaciones de hijo pródigo, entre remordimientos y cicatrices, he granjeado a lo menos experiencia escarmentada de frívolas y especiosas doctrinas. De regreso en mi legítima heredad espiritual, ahondándola y cultivándola, me siento en perfecta comunión con los que me antecedieron. Alumbrado por la misma luz que los guió, descubro a las claras el fundamento y la bondad de sus móviles, que columbraba crepuscularmente en los días de mi descarriada ofuscación. Convertido como mis paisanos Olavide y Vidaurre, desengañado como ellos de la perturbadora herencia del siglo XVIII, que a todos nos perdió, reanudando la interrumpida solidaridad salvadora con nuestros auténticos precursores en el espíritu y el tiempo, puedo al fin repetir sinceramente las palabras de quien acertó, en aquella inquieta y estragada época, prefiguración de la tempestuosa nuestra, a ser el servidor leal de su Dios, de su tradición y de su pueblo; y decir de mí como Jovellanos:

Sumiso y fiel, la religión augusta

de nuestros padres, y su culto santo

sin ficción profesée ${ }^{58}$.

Alcalde de Lima en 1932, ministro de Justicia, Instrucción, Culto y Beneficencia y presidente de Consejo de Ministros en 1934, decano del Colegio de Abogados de Lima en 1935, jefe de Acción Patriótica, al mismo tiempo, convivió en su espíritu, de modo digno y ejemplar, la tarea política con la creación intelectual.

Su renuncia al ministerio y a la jefatura del gabinete es uno de los actos más expresivos de lo que hemos llamado en el caso de Riva-Agüero unidad de vida, que se expresó una vez más cuando el Congreso aprobó la ley del divorcio.

El texto central es el siguiente: «Es de tal manera grave la instauración de un régimen de disolución familiar que trascenderá a lo más hondo y esencial del porvenir peruano, deshaciendo el propio núcleo de la vida social, que protesto en la única forma en que me es posible: formulando inmediata e indeclinable renuncia de mi cargo. No quiero ni debo en mi calidad de ministro de Justicia ordenar la publicación y el cumplimiento de mandatos condenados por mi razón y execrados por mi fe [...]. Al irme del poder, por ajustar escrupulosamente mis actos a mis ideas, ante los espontáneos estímulos de mi deber, por exclusiva fidelidad a mis creencias y en acatamiento a los eternos axiomas que tutelan la existencia de la sociedad, me retiro con la conciencia serena ${ }^{59}$.

58 Cfr. Riva-Agüero 1937-1938: 378.

59 Riva-Agüero en Rodríguez Pastor 1975: XLI. 
En los durísimos enfrentamientos políticos de la década de 1930, Riva-Agüero, con coraje físico y moral, defendió el respeto a las instituciones, el principio de autoridad, el respeto a la persona humana, la preocupación social, y no omitió esfuerzo por agrupar a las personas que alimentaran los mismos propósitos.

Su objetivo central en esos años, que Riva-Agüero vivió con intensidad y afán proselitista, fueron la afirmación y la defensa de la familia, la libertad de enseñanza, la trascendencia de la Universidad Católica al servicio de la Iglesia y del país.

En la intensidad de los enfrentamientos de la década de 1930, algunas voces manifestaron que Riva-Agüero fue fascista. La conclusión es muy distinta; Riva-Agüero, como muchos otros hombres de ese tiempo, vio con simpatía la labor de orden y de progreso que en sus primeros años desarrolló Mussolini en Italia, mas, después de los pactos de Letrán, Riva-Agüero no se unió a la política del partido único ni a la intervención del Estado en tareas educativas.

En una visión objetiva y serena del siglo XX en el Perú, no se puede omitir la consideración del pensamiento y de la obra de José de la Riva-Agüero y Osma, conocedor profundo y analítico de la vida de nuestro país. Además, no debe olvidarse — por encima de simpatías y desafectos- la ejemplaridad moral de un hombre que nunca ocultó su pensamiento y que enseñó a los peruanos la verdad sobre el Perú y el deber de servirlo.

\section{BibLIOGRAFÍA}

BASADRE, Jorge (1983). Historia de la República del Perú, tomos VIII y IX. Lima: Editorial Universitaria.

GÁLVEZ, José (1944). «Honras fúnebres [...], discurso del doctor José Gálvez». En: Mercurio Peruano. Lima, año XIX, volumen XXV, nro. 213, pp. 666-668.

GARCÍA CALDERÓN, Francisco (1949). José de la Riva-Agüero. Recuerdos. Lima: Imprenta Santa María.

PLANAS, Pedro (1994). El 900. Balance y recuperación. Lima: Centro de Investigación y Tecnología para el Desarrollo y las Ciencias Sociales (Citdec).

RIVA-AGÜERO, José de la (1937-1938). Por la verdad, la tradición y la patria (opúsculos), dos tomos. Lima: sin editor.

(1960). Afirmación del Perú. El Perú en su historia, tomo I, prólogo de Víctor Andrés Belaunde y selección de César Pacheco Vélez. Lima: Pontificia Universidad Católica del Perú.

(1960). Afirmación del Perú. Fragmentos de un ideario, tomo II, prólogo de selección y prólogo de César Pacheco Vélez. Lima: Pontificia Universidad Católica del Perú.

(1975). Escritos políticos. Lima: Instituto Riva-Agüero.

RODRÍGUEZ PASTOR, Carlos (1975). «Prólogo». En: Riva-Agüero y Osma, José. Escritos políticos. Lima: Instituto Riva-Agüero, pp. XV-LIV. 


\section{César Vallejo \\ (1892-1938)}

\section{Liliana Checa}



En El siglo de las luces, de Alejo Carpentier, que narra las consecuencias y las repercusiones de la Revolución francesa en América Latina, el escritor cubano elige como protagonista principal de su novela a Victor Hugues, un personaje real, pero lo suficientemente desconocido como para permitirse improvisar su personalidad en función a sus actos. Victor Hughes encarna las contradicciones propias de toda revolución. Masón, girondino, jacobino, robesperriano, napoleónico, al temer estar cercano a la muerte confiesa haber vestido tantos trajes en su vida que ya no sabe con cuál quisiera que se le entierre.

La novela misma no es ajena al conflicto de su personaje. La interrogante parece ser: «Una vez logrado el poder, ¿qué hacer para que los ideales no se desmoronen?».

Si trasponemos esa imagen a la realidad actual, veremos con horror cuán profética resulta la actitud de Victor Hugues; las revoluciones se suceden y contradicen unas a otras durante todo el siglo XX y no hay nada que indique que el panorama del siglo XXI pueda ser más alentador. Y si trasladamos el anhelo de un mundo mejor enfrentado al desencanto de una lucha infructuosa y sin sosiego, que caracteriza a algunos de los protagonistas de la novela de Carpentier, no es difícil establecer un estrecho vínculo con las aspiraciones y las desilusiones que marcarían la vida del poeta peruano César Vallejo.

César Vallejo no es solo el poeta peruano más trascendente del siglo XX, sino también una de las figuras más emblemáticas de la poética de habla hispana de los últimos tiempos. Lo que distingue a la obra de Vallejo de la de muchos de sus contemporáneos es su ruptura con la tradición del pasado y su vinculación con la vanguardia, insertando así a la poesía peruana en una era contemporánea de la que hasta ese momento se había mantenido al margen.

Comparando el aporte del poeta, también vanguardista, Vicente Huidobro, José Miguel Oviedo argumenta: «No cabe duda, sin embargo, de que Vallejo es una clase esencialmente distinta de poeta, no solo respecto al chileno sino respecto a todos los de su tiempo: un poeta visceral, obsesivo, culposo, subterráneo hasta parecer mineral, de voz estrangulada y de una perturbadora densidad. Lo que Huidobro vio con radiante claridad en su impulso celeste Vallejo lo intuyó oscuramente en el barro humano y la tierra nativa que siempre llevó consigo como un pesado e inexplicable karma ${ }^{60}$.

60 Cfr. Oviedo 2001: 318. 
Nacido en 1892 en Santiago de Chuco, un oscuro y perdido pueblo de la sierra de La Libertad, que probablemente deba su mención en el mapa al poeta, la infancia y, en general, toda la vida de Vallejo estarán marcadas por una serie de privaciones. Hijo menor de una familia humilde y numerosa de once hermanos, de valores muy tradicionales y vivencias que condicionarían su vida y su poesía para siempre, Vallejo tiene acceso a una educación con grandes limitaciones en el pueblo vecino de Huamachuco.

«Era fundamentalmente el hombre de una cultura marginal, un provinciano, virtualmente autodidacta por lo que se refiere a la literatura, pues aunque estudió en la universidad y escribió una tesis sobre el romanticismo, el ambiente cultural de Santiago de Chuco y de Trujillo era relativamente pobre [...]. El hogar y la Iglesia fueron instituciones importantes en la primera parte de su vida, bases seguras que desaparecieron de un modo radical al producirse la muerte de su madre y de su hermano mayor, Miguel ${ }^{61}$.

La poesía de Vallejo está impregnada de sus vivencias y sellada irremediablemente por una experiencia que lo marcaría amarga y trágicamente para siempre. En 1920, al regresar de Lima a Santiago de Chuco, Vallejo pasaría ciento doce días en la cárcel, acusado de incitar el desorden y perturbar la paz. Sin embargo, este hecho no sería un impedimento para que desde la prisión escribiera algunos de sus poemas más complejos y originales.

Como afirma Oviedo, cada etapa de la vida de Vallejo dará fruto a un libro con el que el ciclo anterior quedará definitiva e irremediablemente cerrado para siempre: «La vida y la obra vallejianas pueden dividirse en tres claras etapas: su niñez y juventud en el pueblo natural y su capital (hasta 1917); su experiencia limeña (1918-1923); el periodo europeo (desde mediados de 1923 hasta su muerte). Cada etapa está definida por un libro o conjunto poético (más un poema extenso en el último caso) y cada una plantea un radical apartamento respecto al anterior; cada frase le sirve para alcanzar cierto nivel expresivo desde el que luego puede criticarlo, volverse contra él y abandonarlo en la siguiente. Así, la evolución poética de Vallejo registra transiciones violentas y extremas, sobre todo si se piensa que su primer libro tenía fuertes ataduras tradicionales y librescas: en veinte años atraviesa por el postmodernismo, la vanguardia y la poesía social y política sin mirar una sola vez hacia atrás ${ }^{62}$.

La obra poética de Vallejo se reduce a cuatro grandes libros. Los dos primeros, Los heraldos negros (Lima, 1918) y Trilce (Lima, 1922), recogen sus experiencias de infancia y madurez, acentuada por las vivencias traumáticas de la cárcel ${ }^{63}$. Los dos últimos, Poemas humanos y España, aparta de mí este cáliz, ambos publicados póstumamente, recogen su experiencia europea, a partir de 1923 hasta su temprana muerte en 1938, su compromiso

61 Cfr. Franco 1970: 289.

62 Cfr. Oviedo 2001: 319.

63 Extensamente aludida por todos sus biógrafos. 
con la causa republicana durante la Guerra Civil española y, cada uno de manera distinta, alude a la angustia y a la incertidumbre del hombre en el mundo contemporáneo. A esta obra se suma la de carácter ensayístico, y fundamentalmente político, consecuencia de su afiliación al Partido Comunista en Europa y sus frecuentes viajes a Rusia, Vallejo también incursiona, aproximadamente de 1925 a 1935, sin mayor éxito, en el teatro y en la novela, contribuyendo a través de El tungsteno (1931), una novela sobre las duras condiciones de los mineros en la sierra peruana, al tema del realismo social de moda en América Latina en aquellos años.

Algunos de los poemas escritos en adolescencia en Trujillo y otros, producto de su experiencia limeña, formarían parte de su primer libro: Los heraldos negros. La muerte de su madre, ocurrida en 1918, lo acerca a la experiencia del dolor que registran muchas páginas del libro. Los sesenta y nueve poemas que lo integran están divididos en seis secciones que recogen sus vivencias y se caracterizan por el pesimismo y la nostalgia que serán el leitmotiv de gran parte de la obra de Vallejo:

Hay golpes en la vida, tan fuertes... Yo no sé!

Golpes como el odio de Dios; como si ante ellos,

la resaca de todo lo sufrido

se empozara en el alma... Yo no sé!

Son pocos, pero son... Abren zanjas oscuras

en el rostro más fiero y en el lomo más fuerte,

Serán, tal vez los potros de los bárbaros atilas:

O los heraldos negros que nos manda la Muerte ${ }^{64}$.

Si consideramos que este es el poema que inaugura el libro, no es difícil percibir la noción escéptica que tiene Vallejo del mundo, un lugar de castigo, un lugar donde se viene a sufrir, un lugar donde reina la muerte, un lugar donde la experiencia del dolor es más fuerte que la de la vida misma.

Así, en «Heces», un poema que recoge sus vivencias limeñas, dirá:

Esta tarde llueve como nunca; y no

tengo ganas de vivir, corazón.

Esta tarde es dulce. Por qué no ha de ser?

Viste gracia y pena; viste de mujer.

64 Cfr. Vallejo 1956: 13. 
Esta tarde en Lima llueve. Y yo recuerdo

las cavernas crueles de mi ingratitud;

mi bloque de hielo sobre su amapola,

más fuerte que su «No seas así! ${ }^{65}$.

Sin embargo, la nostalgia y el dolor no son los únicos sentimientos que impregnan las páginas de Los heraldos negros. La amargura aparece como un elemento constante, recordándonos una existencia marginal, una vida dura y difícil, de privaciones, plagada de muertes, de miseria, de hambre, de sufrimiento. Así queda manifiesto en «La cena miserable» y en muchos otros poemas del libro.

Hasta cuándo estaremos esperando lo que

no se nos debe... Y en qué recodo estiraremos

nuestra pobre rodilla para siempre! Hasta cuándo

la cruz que nos alienta no detendrá sus remos.

Hasta cuándo la Duda nos brindará blasones

por haber padecido...

Ya nos hemos sentado

mucho a la mesa, con la amargura de un niño

que a media noche, llora de hambre, desvelado ${ }^{66} .$.

Otro de los temas recurrentes en el libro es Dios y los valores tradicionales cristianos bajo los cuales Vallejo ha sido criado. El poema en el que quedan manifiestos los sentimientos encontrados que alberga hacia Dios es "Los dados eternos», dedicado a Manuel González Prada, con quien Vallejo había establecido una relación intelectual a su llegada a Lima.

Dios mío, estoy llorando el ser que vivo;

me pesa haber tomádote tu pan;

pero este pobre barro pensativo

no es costra fermentada en tu costado:

tú no tienes Marías que se van!

65 Cfr. Vallejo 1956: 17.

66 Cfr. Vallejo 1956: 23. 
Dios mío, si tú hubieras sido hombre,

hoy supieras ser Dios;

pero tú, que estuviste siempre bien,

no sientes nada de tu creación.

Y el hombre sí te sufre: el Dios es él! ${ }^{67}$.

Sin embargo, el aporte más trascendente que hace Vallejo, sin restarle importancia a los temas relacionados con la condición humana que el libro explora, sucede en nivel del lenguaje. Un lenguaje que Vallejo fractura para acondicionarlo a sus necesidades propias, un lenguaje que señala su originalidad y lo distingue de sus contemporáneos modernistas, muchas de cuyas inquietudes también comparte. Como afirma acertadamente José Miguel Oviedo:

La originalidad de Vallejo brota de un fondo oscuro que está más allá o más debajo de su experiencia literaria: de su agonía, de una tristeza y una soledad que no cabe sino llamar metafísicas. Cuando el poeta se hunde en sí mismo y deja de lado las alusiones librescas, algunas veces ingenuas, encuentra algo indecible, que solo puede expresar si lucha contra el lenguaje o se inventa uno nuevo; esa dicción torturada, con balbuceos y expresiones cuyo sentido o sintaxis han sido forzados, muestra que el aspecto realmente creador de Vallejo iba en una dirección única, en la que nadie — ni modernistas ni vanguardistas — lo acompañaba. Solo cabe un nombre para calificar esa línea poética: vallejiana ${ }^{68}$.

Su segundo libro, Trilce, aparecerá solo cuatro años después de Los heraldos negros, pero la originalidad lingüística que caracterizaba al primer libro es mucho más avezada en el segundo y pone de manifiesto el proceso de maduración que se ha venido dando en Vallejo. Temáticamente, el poemario trata la amarga experiencia de la cárcel, que marcará irremisible e irremediablemente para siempre a Vallejo.

En Trilce los números son importantes, pero solo porque indican un sentido de armonía y orden que se ha vaciado de significación. En términos cabalísticos el uno es el símbolo de la plenitud, para Vallejo es el símbolo de la soledad individual; el dos es el «acoplamiento» del macho y la hembra, para Vallejo el símbolo de la dialéctica sin objeto; tres es el símbolo de la trinidad y de la perfección, para Vallejo es un símbolo de la generación sin sentido; el cuatro representaba para los antiguos los cuatro elementos, pero para Vallejo simboliza las cuatro paredes de la celda y las limitaciones del hombre. Hay otros números también

67 Cfr. Vallejo 1956: 24.

68 Cfr. Oviedo 2001: 325. 
'absurdos', los nueve meses de la gestación, los doce meses del año. Pero todos están desacralizados. Los números son simples cifras que, como las paredes de la celda, o se suman estúpidamente al mismo número o se multiplican hasta alcanzar cifras tan vacías como ellos mismos ${ }^{69}$.

Los temas que Vallejo desarrolla en Trilce, y que deliberadamente buscan aludir a sus raíces y a las limitaciones del entorno en el que se desarrollan sus primeros años, no han cambiado mucho respecto a Los heraldos negros. Deliberadamente Vallejo parece alejarse de los temas mundanos; sin embargo, las innovaciones a nivel de lenguaje marcan una distancia respecto a su primer libro. Si la nostalgia y la tristeza eran el lugar común de Los heraldos negros, Trilce está caracterizado por una carga muy negativa, por la imposibilidad del hombre para entenderse y comunicarse, por una condición que lo aísla y lo margina irremediablemente. Así, en el poema XVIII dirá:

Oh las cuatro paredes de la celda.

Ah las cuatro paredes albicantes

que sin remedio dan al mismo número.

Criadero de nervios, mala brecha,

por sus cuatro rincones cómo arranca

las diarias aherrojadas extremidades.

Amorosa llavera de innumerables llaves,

si estuvieras aquí, si vieras hasta

qué hora son cuatro estas paredes.

Contra ellas seríamos contigo, los dos,

Más dos que nunca. Y ni llorarás,

di, libertadora! ${ }^{70}$.

Para Vallejo, el encierro físico alude a la vulnerabilidad del hombre, a su condición incierta en un mundo cruel y de valores caducos y desgastados. Si la muerte estaba presente en el primer libro, en Trilce su presencia es aun más notoria, a pesar de no ser directamente aludida. El hombre es impotente frente a la muerte y la vida es un lento y desesperado camino hacia ella.

69 Cfr. Franco 1983: 291.

70 Cfr. Vallejo 1956: 36. 
En la impotencia de la reclusión prevalece y se acentúa la nostalgia de la madre muerta:

Madre, me voy mañana a Santiago,

a mojarme en tu bendición y en tu llanto.

Acomodando estoy mis desengaños y el rosado

de llaga de mis falsos trajines.

$[\ldots]$

Así, muerta inmortal. Así.

Bajo los dobles arcos de tu sangre, por donde

hay que pasar tan de puntillas, que hasta mi padre

para ir por allí,

humildóse hasta menos de la mitad del hombre,

hasta ser el primer pequeño que tuviste ${ }^{71}$.

Vallejo ha vuelto a sus orígenes, ha regresado a la tierra natal para encontrarse con la incomprensión y el olvido, con una falta de libertad impuesta, con la indiferencia del cancerbero que, como bien dice, no hace más que cumplir su deber:

El cancerbero cuatro veces

al día maneja su candado, abriéndonos

cerrándonos los esternones, en guiños

que entendemos perfectamente.

Con los fundillos lelos melancólicos,

amuchachado de trascendental desaliño,

parado, es adorable el pobre viejo.

Chancea con los presos, hasta el tope

los puños en las ingles. Y hasta la mojarrilla

les roe algún mendrugo; pero siempre

cumpliendo su deber.

Por entre los barrotes pone el punto

fiscal, inadvertido, izándose en la falangita

del meñique,

a la pista de lo que hablo ${ }^{72}$.

71 Cfr. Vallejo 1956: 55-56.

72 Cfr. Vallejo 1956: 47. 
Otra preocupación constante de Vallejo en Trilce es el tiempo, un presente que lo angustia, un pasado plagado de muertes y privaciones, un futuro incierto y desconocido.

Vallejo dijo una vez que una nueva poesía podía surgir solamente de una nueva sensibilidad. La presentación 'dramática' de las situaciones, el uso de palabras científicas o coloquiales están estrechamente ligados con las actitudes vitales del poeta. Y en Vallejo no encontramos ninguna satisfacción de sí mismo ${ }^{73}$.

Será, quizá, esa permanente insatisfacción consigo mismo, esa búsqueda insaciable de algo que él mismo no define la que lo llevará a Europa un año después de publicado Trilce, en 1923. Permanecería ahí hasta su trágica muerte en 1938.

Vallejo llega a París el 13 o 14 de julio de 1923, alerta su curiosidad a todas las revelaciones de la ciudad que años más tarde llamará dulce y cruel. Sus primeros pasos lo llevarán de la rue Cadet, donde está alojado, a Montmartre, el barrio legendario de sus lecturas de Escenas de la vida bohemia, de Henri Muger ${ }^{74}$.

Cuando Vallejo se embarca hacia Europa, no tenía nada, más que los vínculos emocionales, que lo atara al Perú. Había cesado su labor como profesor de primaria del Colegio Guadalupe y su poemario más reciente, Trilce, impreso en los Talleres Tipográficos de la Penitenciaría, había suscitado comentarios exaltados y polémicos. Había sido designado corresponsal del diario El Norte, fundado hacía cinco meses por sus amigos de la Bohemia Trujillana. Sus primeras experiencias parisinas aparecen puntualmente a través de sus artículos para El Norte, del mismo modo en el que años más tarde Gabriel García Márquez registraría las suyas en El Espectador.

En 1925 Vallejo comienza a publicar en la organización publicitaria Grandes Periódicos Iberoamericanos y en la revista limeña Mundial. Estará ahora expuesto a una mayor cantidad de lectores y sus escritos se comienzan a adecuar a las exigencias de un público más internacional. Simultáneamente, su transformación política e ideológica lo lleva a abandonar temporalmente la poesía para concentrarse en una literatura de índole social y comprometida con la causa de los más pobres, abiertamente a favor de la revolución ${ }^{75}$. A estos artículos podría sumarse su incursión en el teatro y su relato infantil «Paco Yunque», que, del mismo modo que su novela El tungsteno, evidencia su compromiso con la lucha de clases y la reivindicación de los sectores menos privilegiados.

73 Cfr. Franco 1970: 283.

74 Puccinelli, 1977: XII.

75 Cfr. Oviedo 2001: 337. 
Como se ha mencionado, sus poemas escritos en Europa aparecerían como un homenaje póstumo recopilados a partir de los textos que deja sin publicar al momento de su muerte.

Como afirma acertadamente Oviedo:

Su poesía póstuma es, en realidad, una insuperable síntesis del lenguaje de la vanguardia, que racionalmente rechazaba, y de la nueva visión social (él la llamaba socialista) que había adoptado en lógica correspondencia con su fe marxista; si se piensa bien, eso era justamente lo que quería lograr el surrealismo después de 1929. Así, Vallejo se colocaba a la vanguardia de la vanguardia y le abría nuevos horizontes que pocos habían vislumbrado, dándolo a ese lenguaje una función por completo diferente ${ }^{76}$.

El leitmotiv de sus Poemas humanos es el dolor, la desesperanza, la injusticia, la imposibilidad del hombre por construir un mundo mejor. Esto queda manifiesto en su poema «Los nueve monstruos»:

\author{
I, desgraciadamente, \\ el dolor crece en el mundo a cada rato, \\ crece a treinta minutos por segundo, paso a paso, \\ y la naturaleza del dolor, es el dolor dos veces \\ y la condición del martirio, carnívora, voraz, \\ es el dolor dos veces \\ y la función de la yerba purísima, el dolor \\ dos veces \\ y el bien de sér, dolernos doblemente ${ }^{77}$.
}

Por eso, su poema en prosa «Voy a hablar de la esperanza» es una alusión directa a la angustia y al dolor y a la frustración del hombre por la imposibilidad de cambiar ese destino. Este es el motivo por el que concluye diciendo: «Hoy sufro suceda lo que suceda, hoy sufro solamente».

A lo largo de Poemas humanos predomina el espíritu negativo de Vallejo hacia la vida, pero a este sentimiento se suma el de conminar a los hombres a hacer algo, a no resignarse al dolor y al sufrimiento inherentes a la condición humana, sino a combatirlos, a luchar contra la angustia y el pesar:

76 Cfr. Oviedo 2001: 339.

77 Cfr. Vallejo 1956: 64. 
Hoy me gusta la vida mucho menos, pero siempre me gusta vivir: ya lo decía.

Casi toqué la parte de mi todo y me contuve con un tiro en la lengua detrás de mi palabra.

\section{[...]}

Me gusta la vida enormemente,

pero, desde luego,

con mi muerte querida y mi café

y viendo los castaños frondosos de París ${ }^{78}$.

La impotencia de combatir este mal y este sufrimiento que aqueja al mundo queda manifiesta a través de sus poemas «Intensidad y altura» y «Piedra negra sobre una piedra blanca»:

Quiero escribir, pero me sale espuma, quiero decir muchísimo y me atollo; no hay cifra hablada que no sea suma, no hay pirámide escrita, sin cogollo.

Quiero escribir, pero me siento puma; quiero laurearme, pero me encebollo. No hay toz hablada, que no legue a bruma, no hay dios ni hijo de dios, sin desarrollo.

[...]

Vámonos! Vámonos! Estoy herido;

Vámonos a beber lo ya bebido,

Vámonos, cuervo, a fecundar tu cuerva ${ }^{79}$.

Esta visión se agudiza en «Piedra negra sobre una piedra blanca», donde parece convertirse en profeta de su muerte cercana.

Me moriré en París con aguacero,

un día del cual tengo ya el recuerdo,

78 Cfr. Vallejo 1956: 61.

79 Cfr. Vallejo 1956: 63. 
Me moriré en París - y no me corro-

tal vez un jueves, como es hoy, de otoño.

Jueves será, porque hoy, jueves, que proso

estos versos, los húmeros me he puesto

a la mala y, jamás como hoy, me he vuelto,

con todo mi camino, a verme solo.

César Vallejo ha muerto, le pegaban

todos sin que él les haga nada;

le daban duro con un palo y duro

también con una soga; son testigos

los días jueves y los huesos húmeros,

la soledad, la lluvia, los caminos ${ }^{80} \ldots$

Para Oviedo, «Vallejo quiere desmontar los mecanismos que mueven el mundo burgués y reorganizarlos para mostrar que todo puede ser de otro modo. En 'Un hombre pasa con un pan al hombro...' tenemos una sutil aplicación de los tres términos de la dialéctica marxista (tesis, antítesis y síntesis), pues presenta un contraste tan violento entre los dos primeros que el tercero queda sobreentendido...» ${ }^{81}$.

Un hombre pasa con un pan al hombro

¿Voy a escribir, después, sobre mi doble?

Otro se sienta, ráscase, extrae un piojo de su axila, mátalo

¿Con qué valor hablar de psicoanálisis?

[...]

Un cojo pasa dando el brazo a un niño

¿Voy, después, a leer a André Breton?

Otro tiembla de frío, tose, escupe sangre.

¿Cabrá aludir jamás al Yo profundo?

80 Cfr. Vallejo 1956: 77.

81 Cfr. Oviedo 2001: 343. 
Otro busca en el fango huesos, cáscaras

¿Cómo escribir, después, del infinito? ${ }^{82}$.

El hecho que Vallejo escribiera Poemas humanos durante una etapa de depresión aguda, intensifica el carácter trágico que predomina en todo el libro. Vallejo transmite una visión apocalíptica no solo de sí mismo, sino del mundo desgastado en el que siente que le ha tocado vivir. Como concluye Jean Franco: "Poemas humanos ahonda así en el significado de la crisis que hay entre el hombre y la sociedad. Sus versos muestran cómo el hombre no puede encontrar un sentido a proyectarse hacia un futuro cuando él podría ser distinto o la sociedad distinta. Una sociedad que sufre una crisis industrial solo ofrece desesperanza al hombre; no obstante, ello no significa que Vallejo careciera por completo de fe. Su comunismo no era ninguna variedad de signo utópico, porque no creía en ningún futuro místico, sino que creía firmemente que hay que luchar contra las injusticias. Por eso es una lástima que los Poemas humanos se publicasen separadamente de España, aparta de mí este cáliz, que es la otra cara de la moneda» ${ }^{83}$.

Su contribución a la Guerra Civil española (1936-1939), y cuyo fin Vallejo no viviría para ver, es España, aparta de mi este cáliz. Si bien el poemario fue escrito al mismo tiempo que Poemas humanos, aquí Vallejo se identifica con la causa republicana y apela a la solidaridad de los seres humanos para ayudar a una España que se desangra antes sus ojos. Queda también manifiesta la impotencia de no haberse involucrado más en la guerra e incluso inmolar su vida por la República. Estos sentimientos encontrados de dolor, agonía, frustración y exhortación a la lucha son la esencia de su «Himno a los voluntarios de la República»:

Voluntario de España, miliciano

de huesos fidedignos, cuando marcha a morir tu corazón,

cuando marcha a matar con tu agonía

mundial, no sé verdaderamente

qué hacer, dónde ponerme; corro, escribo, aplaudo,

lloro, atisbo, destrozo, apagan, digo

a mi pecho que acabe, al que bien, que venga

y quiero desgraciarme;

descúbrome la frente impersonal hasta tocar

el vaso de la sangre, me detengo,

detienen mi tamaño esas famosas caídas de arquitecto

82 Cfr. Vallejo 1956: 81.

83 Cfr. Franco 1983: 299. 


\section{$[\ldots]$}

Proletario que mueres de universo, ¡en qué frenética armonía

acabará tu grandeza, tu miseria, tu vorágine impelente,

tu violencia metódica, tu caos teórico y práctico, tu gana

dantesca, españolísima de amar, aunque sea a traición, a tu enemigo! ${ }^{84}$.

El duro enfrentamiento entre apariencias y desengaño queda confirmado en los versos en los que Vallejo admite la dura realidad de la muerte de la que España es víctima:

¡Porque en España matan, otros matan

al niño, a su juguete que se para,

a la madre Rosenda esplendorosa,

al viejo Adán que hablaba en voz alta con su caballo

y al perro que dormía en la escalera.

$[\ldots]$

al sabio, a su bastón, a su colega,

al barbero de al lado —me cortó posiblemente,

pero buen hombre y, luego, infortunado;

al mendigo que ayer cantaba enfrente,

a la enfermera que hoy pasó llorando,

al sacerdote a cuestas con la altura tenaz de sus rodillas ${ }^{85} \ldots$

La invocación de Vallejo a abrazar la causa de la República, a solidarizarse con la miseria humana, es el tema de uno de los poemas más dramáticos del libro, «Masa»:

Al fin de la batalla,

y muerto el combatiente, vino hacia él un hombre

y le dijo: '`No mueras, te amo tanto!'

Pero el cadáver ¡ay! siguió muriendo.

Se le acercaron dos y repitiéronle:

¡No nos dejes! ¡Valor! ¡Vuelve a la vida!'

Pero el cadáver jay! siguió muriendo.

84 Cfr. Vallejo 1956: 96.

85 Cfr. Vallejo 1956: 94-99. 
Acudieron a él veinte, cien, mil, quinientos mil, clamando: 'Tanto amor y no poder hacer nada contra la muerte!'.

Pero el cadáver ¡ay! siguió muriendo.

Le rodearon millones de individuos,

con un ruego común: ‘¿Quédate, hermano!'

Pero el cadáver ¡ay! siguió muriendo.

Entonces, todos los hombres de la Tierra

le rodearon; les vio el cadáver triste, emocionado:

incorporóse lentamente,

abrazó al primer hombre; echóse a andar ${ }^{86} \ldots$

El ciclo de dolor y desesperanza que Vallejo había inaugurado en Los heraldos negros se cierra en España, aparta de mi este cáliz. Si bien el estilo y el lenguaje han evolucionado sustancialmente rompiendo todos los esquemas establecidos y creando un idioma propio de sintaxis que solo podríamos llamar «vallejiana», como sostiene Oviedo, la temática de la frustración, de la desesperanza, de la soledad no solo permanecen sino hasta se agudizan en este último poemario póstumo. Incluso el tema cristiano prevalece con la referencia bíblica al cáliz de la Última Cena del Nuevo Testamento, antes de que Cristo sea entregado por Judas para ser juzgado y crucificado.

En 1982 el escritor colombiano Gabriel García Márquez se hace acreedor del Premio Nobel de Literatura. El discurso que pronuncia en Estocolmo, «La soledad de América Latina», comienza:

Antonio Pigafetta, un navegante florentino que acompañó a Magallanes en el primer viaje alrededor del mundo, escribió a su paso por nuestra América meridional una crónica rigurosa que sin embargo parece una aventura de la imaginación. Contó que había visto cerdos con el ombligo en el lomo, y unos pájaros sin patas cuyas hembras empollaban en las espaldas del macho, y otros como alcatraces sin lengua cuyos picos parecían una cuchara. Contó que había visto un engendro animal con cabeza y orejas de mula, cuerpo de camello, patas de ciervo y relincho de caballo. Contó que al primer nativo que encontraron en la Patagonia le pusieron enfrente un espejo, y que aquel gigante enardecido perdió el uso de la razón por el pavor de su propia imagen ${ }^{87}$.

86 Cfr. Vallejo 1956: 119-120.

87 Cfr. García Márquez 1982. 
Mientras Vallejo ve frustrada su ilusión de un mundo mejor y más justo, y no percibe la realidad mágica latinoamericana que tempranamente había deslumbrado a Pigafetta, García Márquez termina su discurso sobre América Latina con una visión esperanzadora:

Un día como el de hoy, mi maestro William Faulkner dijo en este lugar: 'Me niego a admitir el fin del hombre'. No me sentiría digno de ocupar este sitio que fue suyo si no tuviera la conciencia plena de que por primera vez desde los orígenes de la humanidad, el desastre colosal que él se negaba a admitir hace treinta y dos años es ahora nada más que una simple posibilidad científica. Ante esta realidad sobrecogedora, que a través de todo el tiempo humano debió de parecer una utopía, los inventores de fábulas, que todo lo creemos, nos sentimos con el derecho de creer que todavía no es demasiado tarde para emprender la creación de la utopía contraria. Una nueva y arrasadora utopía de la vida, donde nadie pueda decidir por otros hasta la forma de morir, donde de veras sea cierto el amor y sea posible la felicidad, y donde las estirpes condenadas a cien años de soledad tengan por fin y para siempre una segunda oportunidad sobre la Tierra ${ }^{88}$.

Se trata de la misma América Latina de Vallejo, pero su visión de esta es radicalmente distinta. García Márquez cree en la redención y en la esperanza; Vallejo está expuesto a la miseria, a la experiencia devastadora de la cárcel, a una lucha entre hermanos donde imperan la violencia y la crueldad, a una guerra donde la causa republicana, que Vallejo apoya, pierde ${ }^{89}$. El escepticismo de Vallejo puede compararse con el que el escritor argentino Julio Cortázar manifiesta a través de su novela más emblemática: Rayuela (Buenos Aires, 1963). Encontrar un kibutz paradisiaco, retener la imagen del calidoscopio o alcanzar la casilla nueve de la rayuela son solo utopías imposibles que, sin embargo, todos los personajes de la novela anhelan alcanzar.

Durante su trayectoria, Vallejo ha incursionado en la vanguardia y ha roto con ella, ha sido testigo de los acontecimientos turbulentos de su tiempo y ha asumido un rol activo abrazando el comunismo y la causa republicana en la Guerra Civil Española. No ha sido indiferente a la miseria y a la vulnerabilidad del ser humano y nos ha dejado un legado imperecedero capaz de resistir el paso irremediable de los años y del olvido y de sobrevivir a todos los tiempos.

\section{Bibliografía}

CORTÁZAR, Julio (1978). Rayuela. Buenos Aires: Editorial Sudamericana.

FRANCO, Jean (1970). Introducción a la literatura hispanoamericana, Caracas: Monte Ávila Editores.

88 Cfr. García Márquez 1982.

89 Vallejo no viviría para ver el triunfo de la Falange y del general Franco. 
(1983). Historia de la literatura hispanoamericana. A partir de la independencia. Barcelona: Editorial Ariel S. A.

GARCÍA MÁRQUEZ, Gabriel (1982). «La soledad de América Latina». [Discurso de aceptación del Premio Nobel 1982]. En: www.ciudadseva.com/textos/otros/ggmnobel.htm. (Consulta: 20 de agosto de 2008)

OVIEDO, José Miguel (2001). Historia de la literatura hispanoamericana. 3) Postmodernismo, vanguardia, regionalismo. Madrid: Alianza Editorial, 2001.

VALLEJO, César (1956). Poemas escogidos. Lima: Patronato del Libro Peruano.

(1997). Obras completas. Artículos y crónicas (1918-1939), recopilación y prólogo de Jorge Puccinelli. Lima: Biblioteca de Clásicos del Perú, Banco de Crédito del Perú. 


\section{Honorio Delgado \\ (1892-1969)}

\section{Renato D. Alarcón-Guzmán}



Que amigos y adversarios y el juicio de la Historia sitúen unánimemente a Honorio Delgado como la figura cumbre de la psiquiatría peruana y latinoamericana en el siglo XX refleja no solo el reconocimiento de una obra excepcional, sino también la vigencia de su ecumenismo, la solidez de sus ideas, el brillo de su magisterio y la inspiración inagotable de su mensaje vital. Delgado fue, además de psiquiatra, filósofo, esteta, pensador, científico, biólogo, investigador, lingüista, educador, escritor y ensayista, historiador, un scholar por excelencia. Miembro de la Academia Peruana correspondiente de la Real Española de la Lengua, autor de más de 450 artículos y 24 libros, todos ellos verdaderos clásicos en estilo y sustancia. La unanimidad en el juicio de una obra intelectual es un fenómeno muy raro: en el caso de Honorio Delgado, ciertamente, se justifica plenamente.

Nacido en Arequipa el 26 de setiembre de 1892, Delgado se educó en el Colegio Nacional de la Independencia Americana, hizo sus estudios de premédicas y bachillerato en Ciencias en la Universidad Nacional de San Agustín y emigró luego a Lima, donde ingresó a la Universidad de San Marcos para culminar sus estudios en la vieja Facultad de Medicina de San Fernando. Se inclinó por la psiquiatría desde sus años iniciales. Sus lecturas sobre los más recientes avances en el campo y su conocimiento del alemán lo llevaron a entusiasmarse con la obra de Sigmund Freud, a la que consideró liberadora y audaz. En 1915, siendo aún estudiante de Medicina, publicó, en el diario El Comercio, un artículo titulado precisamente «El psicoanálisis», y optó luego el grado de médico en 1918, con la brillante tesis La doctrina del psicoanálisis, la primera exposición sistemática de las ideas de Freud en español. La profunda curiosidad intelectual de Delgado, su pasión de profesional atento al desarrollo de su disciplina, su búsqueda juvenil y entusiasta, pero también objetiva y confiada, lo incitaron a iniciar una activa correspondencia con Freud en 1919, la cual se extendió por 15 años, incluso más allá de la ruptura conceptual o doctrinaria con el fundador del psicoanálisis, hacia comienzos de 1930. Conoció a Freud en el Congreso Internacional de Psicoanálisis celebrado en Innsbruck, Austria. Freud lo distinguió como «el primer psicoanalista latinoamericano» y Abraham, connotado editor y miembro del círculo freudiano, pu- 
blicó dos artículos de Delgado en Imago y en el International Journal of Psychoanalysis. Muchos autores de la época consideraron que Delgado debió ser el traductor oficial de las obras de Freud al español, pero la designación recayó en López Ballesteros y la primera publicación castellana del opus freudiano vio la luz en 1923. Hacia mediados de la década de 1930, Delgado se apartó del psicoanálisis, describiendo el proceso como «la corrección progresiva de una actitud influenciada por la aplicación de esquemas hermenéuticos a todos los aspectos de la vida psíquica» y reclamando la vigencia de «las esencias irreducibles de la naturaleza humana, sin las cuales no sería posible la aparición del mundo del espíritu». Criticó los excesos de la doctrina, pero no dejó de reconocer el extraordinario valor intelectual del fundador del psicoanálisis y el brillo y validez de sus mejores intuiciones en torno a la dinámica de la vida mental.

Autodidacta en lo fundamental, solo reconoció a Hermilio Valdizán como su maestro. Junto a él, fue cofundador y director de la Revista de Psiquiatría y Disciplinas Conexas (1918-1924) y del Seminario Psicopedagógico (1919). Ocupó la jefatura de la cátedra de Psiquiatría en la Facultad de Medicina de la Universidad de San Marcos, desde la muerte de Valdizán (1929) hasta 1960. En 1938, fundó con el profesor J. Óscar Trelles, el eminente neurólogo peruano, la Revista de Neuro-Psiquiatría, la segunda más antigua y duradera en el continente latinoamericano. Fue elegido decano de San Fernando durante los difíciles momentos del conflicto desatado por la Ley 13417 (cogobierno estudiantil) y, luego de la renuncia masiva de la plana docente sanfernandina en 1961, fue el primer rector de la nueva Universidad Peruana de Ciencias Médicas y Biológicas, luego Universidad Peruana Cayetano Heredia (UPCH), cargo académico en el que permaneció hasta su desaparición física en 1969. Aparte de ello, ejerció funciones de liderazgo en numerosas entidades y organizaciones nacionales e internacionales en los campos de medicina, psiquiatría, filosofía, investigación, lengua y cultura.

La riquísima y compleja gama de intereses intelectuales y creativos de Delgado puede ser examinada desde diferentes perspectivas. La cronológica permitiría tal vez apreciar la evolución de sus ideas en el tiempo, mostrando la simultaneidad y profundidad de sus múltiples quehaceres. La temática haría explícito el amplio espectro de aquellos intereses, pero sacrificaría conexiones eventuales, no necesariamente casuales. La separación entre logros explícitamente médicos y no-médicos introduciría un elemento de artificialidad que no haría justicia a la armónica integridad de su obra. Por ello, un enfoque que llamaríamos «mixto» tal vez haga posible la visión enteriza y cabal de los trabajos de quien alguna vez escribiera que «el ejercicio de la razón [...] alimenta el anhelo humano de certeza absoluta o, por lo menos, de creencias que den sentido y orientación a la existencia». La producción intelectual de Delgado fue un ejercicio fecundo de esa razón, orientada a la búsqueda de verdad, sabiduría y trascendencia. 
Puede especularse que su alejamiento del credo psicoanalítico fue también debido, en parte, a que la misma curiosidad que lo llevó a «descubrir» a Freud, continuó bullendo en su mente, hermanada con un objetivo más pragmático: ayudar a sus pacientes. Se ha dicho de Freud que, en cierto modo, inauguró la llamada psiquiatría ambulatoria al enfatizar el papel y el impacto de la psicoterapia en el manejo de todo paciente. Delgado jamás desconoció tal objetivo: antes bien trató de alcanzarlo utilizando todos los medios que la investigación y la experiencia clínica de su tiempo le permitieron. Su trabajo cotidiano, a lo largo de más de cuarenta años, en el viejo Hospital Víctor Larco Herrera, con pacientes, psicóticos o no, profundamente perturbados, le exigió extender la mirada a la otra vertiente del trabajo psiquiátrico, la biológica. Así, él introdujo el uso del nucleinato de sodio en el manejo de la agitación psicótica, en 1917, y el uso de fenobarbital para el control de convulsiones, en 1919. Estuvo entre los primeros que en América Latina aplicaron malario-terapia a paralíticos generales, la histórica apertura de una noción puramente biológica (o neurobiológica) a conductas que hasta entonces recibían las más oscuras y contenciosas explicaciones; tal como lo hizo con Freud, se relacionó con Wagner von Jauregg, Premio Nobel de Medicina 1927. Y fue Delgado el primero en América Latina que utilizó la clorpromazina en el tratamiento de la esquizofrenia, apenas dos años después de la publicación de las primeras experiencias con el fármaco, por Delay y Deniker, en París. A su pedido, Óscar Trelles, su amigo y colega, trajo muestras del medicamento a Lima. Un memorable coloquio científico celebrado en 1956, testimonió un auténtico esfuerzo pionero, como muchos que Delgado tuvo oportunidad de liderar. En 1957, Delgado fue uno de los cofundadores del Collegium Internationale Neuro-Psychopharmacologicum en Zúrich.

Como jefe del Departamento de Psiquiatría en la Facultad de Medicina de San Fernando, Universidad de San Marcos, por casi treinta años, Delgado aglutinó un gran número de discípulos y colaboradores que, en base a un excelente y sostenido trabajo académico y de investigación, documentado en los volúmenes de la Revista de NeuroPsiquiatría y en muchas otras publicaciones, generó lo que muchos, a lo largo y ancho de América Latina, reconocieron y llamaron la Escuela Psiquiátrica Peruana. Este grupo dominó buena parte del devenir académico de la psiquiatría latinoamericana y atrajo, además de una pléyade de psiquiatras peruanos, a distinguidos profesionales de otros países del continente. En su seno y a base de estudio intenso y sistemático, diálogo racional y discusiones a veces apasionadas bajo la guía sapiente y objetiva del maestro, las labores didácticas y clínicas se desenvolvían armónica y sólidamente. Las vertientes de esta labor de décadas pueden tal vez reunirse en una trilogía sugerente, portadora del más puro sello delgadiano: aceptación y práctica de un humanismo genuino y cabal, ejercicio de un eclecticismo pragmático y bien entendido, y cultivo y desarrollo de la 
fenomenología como instrumento esencial del trabajo psicopatológico y clínico. Examinemos sucintamente cada uno de estos componentes.

El Diccionario de la historia de las ideas define humanismo como «un esfuerzo por rescatar el conocimiento humano de la opresión autoritaria y por reivindicar su libertad [...]; el primer intento histórico por construir un cuerpo de conocimiento que respondiera a las exigencias cuotidianas de la vida privada y pública del ser humano y que pudiera servir, por lo tanto, como instrumento efectivo en el enfrentamiento de su futuro [...]; un esfuerzo por romper con el pasado y abrir al hombre la posibilidad de un tipo de vida diferente». La historia universal registra con fidelidad la inmensa contribución del humanismo en el devenir cultural y epistemológico de nuestra especie. Delgado y su escuela se propusieron cultivar este humanismo desde la cátedra, en el aula, en sus escritos, en eventos disciplinarios y científicos, de hecho —en el caso del maestro- en su vida y en su obra. Muchos de sus trabajos sitúan al hombre en el centro de una preocupación intensa ante las amenazas de la desustanciación. Consciente de la exquisita fragilidad del espíritu humano frente al arrollador avance de la tecnología, Delgado temía y censuraba con pasión toda seña de inautenticidad, «ese vulgar y lamentable estampado humano, a menudo encubierto y tendencioso». El humanismo — decía— «es labranza personal», reconocimiento de la singularidad, «eternidad y autonomía de las esencias», uso responsable de la razón opuesta por igual a un subjetivismo intuitivo o a una crítica rígida y enceguecedora.

En De la cultura y sus artífices, probablemente su obra escrita mejor lograda, fuera de sus textos psiquiátricos y filosóficos, Delgado articula su concepción de humanismo en la trayectoria de varios personajes que fueron, sin duda, sus héroes intelectuales. Nos habla, entre muchos otros, de Gracián y su concepción del «hombre de bien [...] que rige su existencia por los más altos propósitos, sensible a lo bueno y más a lo muy bueno», aquel cuya superioridad «no se cifra en tener ni en aparentar, sino en ser». Nos habla de Karl Jaspers, para quien «la entidad del hombre está allende su ser empírico, en una dimensión trascendental, en la que se confunden la fe en lo absoluto con el hontanar de lo intrínseco». Y nos habla de Castiglione, para quien «la existencia y la acción son demanda responsable frente a la realidad de los fenómenos: fundamento y asidero del mundo; frente a la realidad del propio ser personal, sustancia inexhausta del esfuerzo; frente a la realidad del misterio, fuente de posibilidades de trascendencia y ahonde en lo infinito».

El humanismo como fenómeno histórico-cultural, como experiencia trascendente, como desideratum moral y como creación antropológica ocupa, pues, lugar prominente en la obra delgadiana. No podía faltar, por lo tanto, en su personalización profesional: el ejercicio de la medicina. El «don de humanidad y abnegación» entraña una actitud cordial de acercamiento al doliente para cuidarlo y servirlo. En tanto que ente anímico y ser espiritual, más allá y por encima de su caparazón biológica, el hombre engrana el 
mundo exterior «con el mundo inmaterial de las esencias, los valores y las exigencias, que solo adquieren sentido gracias a la capacidad de comunicación verbal, de concebir ideas e ideales, de actuar y producir con la conciencia de la propia libertad y con la convicción de una objetividad metaempírica». El humanismo médico que postula Delgado es una armoniosa consolidación de estado espiritual, deber moral y praxis redentora. Ser médico, nos dice, significa poseer «el don de la humanidad, una suerte de sensibilidad y simpatía para el ser de cada hombre enfermo, a quien se comprende y se atiende tanto por sí mismo, en su situación concreta, cuanto como prójimo, semejante y copartícipe del destino común, colocado en el tiempo frente a la vida, frente a la muerte y frente a lo espiritual e imperecedero".

En su obituario a Albert Schweitzer, Delgado brinda una vez más nociones esenciales de un humanismo intemporal porque es, en verdad, para todos los tiempos. Este se caracteriza por «oponer al desmedro de la conducta reinante, la voluntad de elevación moral fecunda en la actitud reverente frente a la vida [...] en vez del subjetivismo infecundo y de la relatividad de todo, cuyas consecuencias últimas son el nihilismo nivelador y la inseguridad universal». Mensaje trascendente y prístino.

Eclecticismo es un término que ha conocido cimas de popularidad y aceptación, así como acantilados de crítica y desprecio. Como en toda creación humana, ambas apreciaciones contienen elementos válidos y veraces, al tiempo que excesos ignaros y hasta demagógicos. Históricamente, resultado de afanes de integración de antípodas ideológicas y prácticas, el eclecticismo ha sido tildado como trascendente, objetivo, útil y ecuménico, pero también como superficial, utilitario, parcial e irresoluto. Hay gente que puede llamarse ecléctica sin serlo y la hay, también, la que practica un eclecticismo sano y constructivo, sin a veces saberlo o aceptarlo. La psiquiatría ha sido y es campo propicio para estas polémicas y para desenlaces a veces imprevisibles. Nadie podría (o debería) desconocer el inmenso caudal subconsciente descubierto por el psicoanálisis, la vigencia de elementos cognitivos para la corrección de perspectivas defectuosas propiciada por el enfoque conductista, la necesidad de un rescate armonioso de esencias espirituales abogado por el existencialismo, el enfoque cultural pleno de vigencias telúricas, o la búsqueda de mantenimiento y mejora de la calidad de vida mediante técnicas de rehabilitación física o recreativa. Nadie podría negar la validez de un diagnóstico que reconozca los elementos bio-psico-socio-culturales de una salud mental genuina y alcanzable. Nadie podría soslayar la necesidad de un tratamiento que corrija disbalances bioquímicos o moleculares, al tiempo que provea una psicoterapia que optimice la utilización de potenciales recursos recuperativos contenidos en lo que Delgado llamó vis medicatrix naturae. Por último, nadie podría desmerecer el valor de una estimación pronóstica que incluya cuerpo y mente, posibilidades físicas y emocionales, objetivos y expectativas en relación con el uso de fármacos y el cultivo sistemático de recursos subjetivos o espirituales. 
Todos estos elementos pueden ser claramente suscritos por una visión ecléctica de la teoría y la práctica de la psiquiatría. De hecho, Delgado abogó por un eclecticismo sólido y persuasivo. No otra cosa sugiere su propia trayectoria profesional y científica: del psicoanálisis rescató el significado valioso de experiencias dolorosas y traumáticas; reconoció en la genética y luego en la psicofarmacología la vigencia de hechos y realidades tan innegables como la biología que los nutre; abogó decididamente en causas de psiquiatría preventiva, educación y rehabilitación, reconociendo la veta de cronicidad en muchas enfermedades mentales; y mostró, con el ejemplo de su vida y su legado, el ideal de integración —e integridad — ínsitos en una visión de total armonía entre el ser y el quehacer.

Por otra parte, hay aquellos para quienes el puro eclecticismo pareciera conformarse solo con seleccionar partes de diferentes sistemas y postular su uso, dejando sin resolver las contradicciones que indudablemente pueden persistir entre tales sistemas. El eclecticismo — dicen estos críticos — no es una ideología (de hecho, no pretende ni debería serlo) y parece basarse más bien en una posición eminentemente utilitarista y pragmática en la que la arbitraria yuxtaposición de doctrinas y técnicas de diferentes sistemas puede resultar en una incoherencia fundamental. Conociendo los principios fundamentales de la obra de Delgado, es perfectamente posible asumir que él también suscribiría estas críticas a un eclecticismo obviamente superficial, zigzagueante y más bien crematístico. Es más, probablemente él fomentaría una suerte de sincretismo psiquiátrico opuesto a la adopción inflexible de un eclecticismo ideologizante. Recordemos que un predicador de la libertad intelectual para todo individuo jamás aceptaría las estrecheces de una ideología. Filosóficamente, se define al sincretismo como el sistema que se empeña en reconciliar o unificar elementos inicial o aparentemente inarmónicos. En el campo de las religiones — donde esta idea ha alcanzado más vigencia-, el sincretismo es generalmente el resultado del contacto y la interpenetración de diferentes culturas. No hay razón entonces, nos diría Delgado, para no pensar en la posibilidad de combinar, aplicar y, esencialmente, aspirar a una conceptualización sincretista de la psiquiatría y sus contenidos. En su afán de superación continua y sistemática, Delgado posiblemente postularía que el sincretismo es una etapa avanzada del puro eclecticismo y se constituiría así en el colofón de un proceso de búsqueda que refleje voluntad de apertura plena y tolerancia básica, en aras de intereses superiores. La condición esencial es la de un no-dogmatismo crítico, precisamente una característica fundamental en el pensamiento y las ideas de Honorio Delgado.

Edmund Husserl definió el enfoque fenomenológico en la filosofía postulando que las cosas o los hechos se presentan o producen con prescindencia de cualquier supuesto. Los fenómenos — sea cual fuere su naturaleza — se ofrecen a una conciencia cuyo rasgo fundamental es la intencionalidad, de modo que el mundo se da como un correlato intencional de esa conciencia. Sobre estas bases, mas no sujetándose dogmáticamente a ellas, Karl Jaspers, desde la Escuela de Heidelberg, enfatizó el estudio descriptivo y detallado de la 
psicopatología ofrecida por el paciente, en respuesta a la comunicación espontánea y a la búsqueda empática del clínico. Los signos y síntomas de la enfermedad mental se esculpen tan claramente que pueden ser reconocidos con la misma certeza «con que el histólogo describe una célula bajo el microscopio», metáfora utilizada por seguidores de Jaspers. En 1913, el psiquiatra y filósofo alemán publicó Psicopatología general, una opción fenomenológica clara y sólida para la consideración holística de síntomas y síndromes en la clínica psiquiátrica. Una vez más, la visión progresista de Honorio Delgado se tradujo en su intenso cultivo de este abordaje clínico liberado de ataduras ideológicas o de presuposiciones sinuosas. A partir de la década de 1940, Delgado y su escuela iniciaron la publicación sistemática de estudios clínicos fenomenológico-descriptivos de riqueza y solidez excepcionales. Este aspecto de su obra culminó con la publicación, en 1953, de su Curso de Psiquiatría, obra que tuvo amplísima difusión en todo el mundo hispanohablante a lo largo de seis ediciones, hasta 1969 (desde la segunda, a cargo de la prestigiosa Editorial Científico-Médica de Barcelona), además de una reedición de la última, en 1993, como parte de sus Obras completas. Este texto ha contribuido a la formación de centenares de psiquiatras latinoamericanos y españoles a lo largo de cinco décadas. Su valor académico ha sido también reconocido en los exigentes ámbitos de la psiquiatría europea, la alemana y la francesa en particular.

El Curso es un compendio fenomenológico enjundioso pero a la vez preciso y sobrio. Con lenguaje elegante, Delgado suscribe el concepto jaspersiano de una conciencia psicológica, empírica, relativa y contingente de los síntomas psiquiátricos, los cuales describe y explica con clara objetividad, en muchas áreas superior a la del maestro de Heidelberg. En la sección de Psiquiatría General o Psicopatología describe, por ejemplo, las funciones de la vida intelectual (adquisición, conservación, elaboración y creatividad) y provee información y ejemplos clínicos de síntomas inherentes a todas las parcelas psíquicas (anormalidades de la percepción, el pensamiento, el sentimiento, las tendencias instintivas, la voluntad, la conciencia del yo, el tiempo anímico, la memoria, la atención, la conciencia y la inteligencia). Articula luego estos síntomas en síndromes y, más aún, en todas las entidades clínicas conocidas, descritas en la segunda sección del libro, Psiquiatría Especial, que, además, incluye capítulos sobre psicoterapia, higiene mental y psiquiatría forense. No es exagerado afirmar que este libro es un clásico de la más pura factura delgadiana.

Pero el maestro peruano fue mucho más allá. Formuló contribuciones originales a la fenomenología y psicopatología de su tiempo y del actual. En la ruta de Husserl, Brentano y Scheler desarrolló importantes innovaciones en torno a la intencionalidad de la actividad consciente, resaltando la polaridad entre conciencia y objeto, y postulando un esquema seminal en relación con la patogénesis de la esquizofrenia. Este esquema incluye tres disyunciones fundamentales: la primera entre el mundo interior del paciente y el mundo exterior, a la que llamó autismo; la segunda entre el yo y el contenido de la conciencia 
(ego-anajoresis); y la tercera, dentro del contenido consciente, entre el predicado y el sujeto de conocimiento que le corresponde (quiebra de categorías). La esquizofrenia reflejaría así, en su conjunto, una desvirtuación de la finalidad propia de los actos y funciones de la vida psíquica, proceso que Delgado llamó atelesis, ruptura que anticipó conceptualmente la desintegración de atención, memoria y cognición en el proceso psicótico.

Existe, finalmente, acuerdo en que otras contribuciones originales de Delgado en este campo atañen a la disgregación y ambivalencia, alteraciones nucleares del llamado pensamiento esquizofrénico; a la distinción entre delusión y delirio y entre delusión e idea delusiva; al concepto de «estado de ánimo delusional» equivalente a la trema de Conrad; y a la clasificación de bioneurosis y psiconeurosis. Su balanceado y armónico afronte fenomenológico lo llevó también a cuestionar la idea de irreversibilidad del proceso psicótico (postulada por el mismo Jaspers), las densas elaboraciones existencialistas de Binswanger y sus seguidores y el afán homogenizante de un rígido cartabón tipológico.

Esto último conduce a otra área de interés y enfoque profundo por parte de Delgado: el diagnóstico psiquiátrico. Con base en su bien elaborado abordaje fenomenológico, Delgado abogó desde la década de 1950, por un diagnóstico que utilizara criterios eminentemente descriptivos y debidamente jerarquizados, libre de contaminaciones ideológicas o interpretaciones precipitadas, nutrido por una causalidad multifactorial y con reconocimiento apropiado de las bases biológicas de la enfermedad mental. Al mismo tiempo, enfatizó la necesidad de investigación sistemática destinada a la demostración de confiabilidad y validez diagnósticas y a la aceptación de diferentes niveles operativos en la psiquis humana.

Delgado fue sobrio en el uso de adjetivos para delinear diversos aspectos de su contribución académica. No obstante, su visión del diagnóstico psiquiátrico lo situó como legítimo abanderado del «afronte neokraepeliniano», etiqueta utilizada por los psiquiatras norteamericanos que a partir de la década de 1970 —es decir, dos largas décadas después de que Delgado iniciara su prédica y postulara una nosología más objetiva y clara, contribución que aquellos por cierto ni conocieron ni reconocieron- produjeron las dos últimas versiones del Manual diagnóstico y estadístico de trastornos mentales (DSM), de la Asociación Psiquiátrica Americana (APA). El DSM delineó entidades diagnósticas con un criterio eminentemente categorial, inspiración nomotética (estudio de muchísimos casos, no situaciones individualísticas), estructura politética (basada en varios criterios) y modelo prototípico (casos-modelo). Delgado había ya postulado estos requerimientos mucho tiempo atrás. Él también había propuesto una catalogación de los niveles o planos de la vida individual (físico/material, biológico, anímico y espiritual) que precedió por décadas y aún superó conceptualmente al célebre enfoque bio-psico-social de Engel, presentado en 1977. No sorprende, por lo tanto, que una fenomenología bien entendida, como la 
que Delgado estudió y practicó, sustente y respalde hoy un diagnóstico multiaxial y una visión multidimensional de la salud y la enfermedad mental. Es más, la concepción de Delgado supera al manual norteamericano en su enfoque principista (objetivo y crítico, no comprometido), su ámbito de aplicación académico-clínica, su conceptualización nosológica y su estilo textual y técnico.

Tampoco sorprende, por cierto, que Delgado y su escuela trasladaran al terreno didáctico todos aquellos principios rectores de su obra intelectual, académica y clínica. Sobre un incuestionable background humanístico, la docencia del maestro — primero en San Fernando y luego, a través de sus discípulos, en Cayetano Heredia - recogió el énfasis fenomenológico-descriptivo, el detallado afronte clínico-anamnésico, la etiología multifactorial y el potencial de una psicoterapia integral. Aun antes de la escisión que dio lugar a la fundación de la UPCH, ya se habían establecido en San Fernando estructuras curriculares secuenciales e integradas. El hospital psiquiátrico (aun cuando modernizado) era el escenario fundamental de la enseñanza, pero ya desde la década de 1960, los servicios ambulatorios y las unidades psiquiátricas en hospitales generales comenzaron a utilizarse sistemáticamente. Ello contribuyó a una visión más amplia de la psicopatología, al reconocimiento de entidades clínicas más allá de las psicosis y a una relación más vigorosa entre psiquiatría y otras ramas o campos de la medicina.

Delgado fue, sin duda, cultor decidido del formalismo académico europeo de la época. Para él, las lecciones teóricas o las presentaciones clínicas eran instancias de necesario eruditismo. No obstante, apoyó el uso del pequeño grupo como instrumento pedagógico fundamental, favoreció la necesidad de experiencias clínicas directas entre alumno y paciente bajo adecuada supervisión, fomentó la presentación y el uso de las patologías más frecuentes en los ejercicios docentes, intuyó una aceptación racional de la llamada medicina psicosomática, previendo tanto sus excesos como la utilidad de su brazo clínico, la moderna psiquiatría de enlace. Todo ello nutrido por la prédica y la práctica de un humanismo que hiciera de la relación médico-paciente no solo un encuentro trascendente sino una actividad de claros objetivos clínicos y terapéuticos. La relación médico-paciente para Delgado fue, como ya se ha dicho muchas veces, un vínculo de horizontalidad y simetría, de convergencia valorativa y de beneficios predecibles.

Otros dos temas que no podían ser ajenos al interés omnisapiente de Honorio Delgado aluden también a su vena filosófica. Son ellos, la identidad y el exilio. El maestro definió el concepto de identidad, estudió su formación, lo aplicó a situaciones y personajes concretos y, por cierto, delineó elocuentemente la identidad del médico. La identidad es, o puede ser, idea maciza o noción atomizada; sello regio o caos impenetrable, engendro y suposición individual o creación colectiva. En relación con esto último, es menester recordar, con Buber, que «no hay meramente una especie humana sino también pueblos, no meramente un alma humana sino también tipos y caracteres, 
no meramente una vida humana sino también estadíos en la vida». Y para Delgado, esa «relación del pasado con el porvenir plasma la vocación del hombre en el mundo, la orientación singular de su personalidad», es decir, la identidad como concepto enterizo, vinculador, permanente pero dúctil en la perenne y mutua relación entre individuo y sociedad.

Esta conceptualización dinámica de identidad es crucial en el examen delgadiano del tema. A despecho de la variedad y renovación de nuestra vida — escribe — siempre somos la misma persona, idéntico sujeto. Lo capital de la identidad personal «es la dirección cualitativa ajena al mero recordar», a pesar de lo cual «no todo es personal en la persona»; lo que le da carácter original «es la presencia de potencias germinales que se incorporan a nuestro vivir»: Delgado llamó a este proceso el devenir, definido como el despliegue de las disposiciones más características del individuo, un sentimiento inequívoco del ritmo y el tono singular del alma, una imagen viva de las peculiaridades de la relación del hombre con su mundo concreto y con el mundo de sus ideales y una medida de la energía manifiesta en la manera de ser autónomo o heterónomo en las situaciones más significativas para el destino personal. Esto último es la autodeterminación: la identidad, «fuente de los actos libres y trascendentes del hombre es, primeramente, posibilidad de realizaciones». Delgado suscribe la noción jaspersiana de que «el hombre, ser complejo, descabal, inarmónico y psicomáquico tiene ansia de unidad, ansia que es anhelo, inquietud, congoja y también posibilidad de trabajo interior y de revelación de sí mismo». Y en frase que no refrena del todo un tono apasionado, nos dice que «más que resoluciones y propósitos concebidos apretando las mandíbulas y los puños, lo eficaz es la contemplación de la imagen que se desea ver encarnada en uno mismo».

En el campo colectivo, Delgado recurre al análisis del mito como fuente y reflejo «de todos los aspectos y modos de ser del pueblo y de las manifestaciones individuales». En explicación antropológico-cultural de gran mérito didáctico en torno a un pasaje crucial en la forja de una identidad peruana, iniciada con la fundación del Cusco por Manco Cápac, Delgado afirma que el mito de los hermanos Ayar, «lejos de implicar una mera versión fabulosa del origen de los emperadores del antiguo Perú, nos presenta innúmeras relaciones acerca de la constitución de la familia y de la sociedad primitivas». Delgado puntualiza «todo un mundo de experiencia religiosa plena de elevación y ascetismo y de disciplina social viva y operante». Y traslada sus planteamientos sobre la identidad al terreno filosófico, con una esperanzada invocación americanista: «Tal vez en América se esconden reservas de pensamiento virginal, recompensa posible para metafísicos amantes de la aventura de rejuvenecer la visión del ser trasminando lo arcaico».

Delgado va más allá en su esbozo de una identidad colectiva para los países iberoamericanos: «El futuro próspero de estos pueblos — escribe-, ligados por la religión, el idioma, la raza, el suelo y la tradición común, depende forzosamente de un perfecto 
entendimiento entre ellos [...] con la exaltación de la conciencia de un destino compartido». El conocimiento mutuo de estos pueblos, añade, «se cumplirá en la medida en que cada uno logre hacerse cargo de su verdadera entidad, de sus valores autóctonos, de sus realizaciones y de sus aspiraciones». Muy pocas veces se ha descrito mejor la idea de una identidad social acabalada.

En cuanto a la identidad del médico, Delgado la sitúa «en el cuádruple poder que lo aproxima a la divinidad»: la providencia de su saber que le permite desentrañar el proceso de la enfermedad; la predestinación que introduce un orden terapéutico; la libertad creadora y responsable en la toma de decisiones; y la delineación del bien y del mal «a la que debe las luces de su derechura moral». Y Delgado, el humanista, concatena esta su vocación fundamental con su faz de magisterio socrático para brindarnos la esencia de su concepción de la identidad en este bello pasaje: «[...] en aquel cuya tabla de valores se expande por lo alto, al que pertenecen el verdadero amador, el artista, el investigador, el héroe y el santo [...], quien se da de preferencia a los valores de las cosas por sí mismas, de las personas, de la naturaleza, del espíritu, vive la duración de manera profunda. En el fluir de su existencia alternan momentos de elevación, de plenitud y entusiasmo, en que el tiempo le ofrece todo lo que puede darle, incluso la trascendencia de lo temporal, con momentos triviales, vacuos, negativos. La estructura peculiar de su devenir no es ni el abandono ni la prisa, formas de la temporalidad vulgar son la tensión, forma creadora propia de la duración fructífera».

La lectura cuidadosa de varios textos del maestro y la vigencia del humanismo moral como fuerza rectora fundamental de toda su obra permiten también explorar el tema del exilio desde, por lo menos, dos nuevas perspectivas. La primera se centra en el carácter voluntario de la separación o del alejamiento del hogar o de la patria y tiene tanto basamento biográfico como documentación escrita. Delgado emprendió una suerte de exilio cuando a los 22 años dejó su Arequipa natal para continuar sus estudios de Medicina en Lima. Su estancia en la capital, tal como la describen varios de sus contemporáneos y estudiosos de su obra, pudo haber reflejado fundamentalmente la persistencia tenaz del legado conductual y moral de su familia, quien sabe como recurso defensivo ante el embate de la capital, ciudad extraña, de escarceos mundanos, de informalidades provocadoras. $\mathrm{Su}$ brillo intelectual y su capacidad de trabajo hicieron de este exilio etapa decisiva en una trayectoria de ribetes históricos.

No extraña entonces que el comentario más decidor de Delgado en relación con el tema del exilio tenga un carácter positivo, optimista, pleno de admiración evocadora hacia el personaje protagónico. Se trata de sus entusiastas artículos sobre Antonio Raimondi y la historia de su exilio de Italia al Perú. Al aclarar que a los 24 años, Raimondi «no emigra por casualidad al Perú ni se expatria por obra de circunstancias políticas». Delgado señala sin ambages el carácter voluntario de este exilio, su carácter constructivo, de búsqueda 
(«explorar y estudiar esta tierra de promisión», nos dice Delgado), de «leal generosidad». Los hazañosos viajes de Raimondi a lo largo y a lo ancho del Perú «son los más felices en la existencia del apasionado descubridor de horizontes», del ilustre exiliado voluntario,

Pero hay más en la historia de este exilio. Delgado nos dice que Raimondi viene al Perú «lleno de amor ardiente al mundo encantado del trópico»: el exilio como afán de exploración, como carta de ciudadanía universal. Delgado evoca al Raimondi, cuya «relación con el ambiente no es abstracta sino personal y entrañable [...] lo vive como paisaje con fisonomía que habla a su alma»: exilio como obra de ternura, como entrega de pasión y de espíritu. El Perú «es el principio y el fin» de la vida de Raimondi que trabajó en nuestro país por cuarenta largos años para darle, según Delgado, «la conciencia de su propia fuerza... [pues]... no es solo el revelador del Perú en el sentido del conocimiento positivo sino también y en modo relevante, el incitador a realizar sus más auténticas posibilidades»: exilio como ejercicio de trascendencia personal y colectiva.

El segundo enfoque delgadiano sobre este tema surge del venero moral que informa la obra del maestro. Es lo que él llamó «exilio moral», la devastación ética, la alienación interpersonal, la «desorientación valorativa por pérdida de la fe», para usar sus propios términos. La saga de este tipo de exilio se articula en «los tres círculos de influencia formativa (o deformadora) de la personalidad: el hogar, las instituciones de enseñanza y la vida pública». Este exilio es básicamente un extravío, un alejamiento de las genuinas esencias humanas, una excursión a parajes ruinosos — más terrible porque son meandros interiores e interiorizados-, configurando una escena de abrumadora desolación. Y este exilio moral es trágico. Delgado, clínico por antonomasia, lo pinta como «una íntima insatisfacción que envenena la vida; un descorazonamiento capaz de llevar hasta el suicidio; un hedonismo desenfrenado...; una perversión de los instintos espirituales...».Y sus consecuencias revelan la infelicidad, el desajuste, la inemancipable condena a una alienación que es tanto intrahumana como interhumana. Delgado las describe con prosa lapidaria: «Los hombres se desarraigan cada vez más de su suelo natal y olvidan sus usos y costumbres; el trabajo se realiza de ordinario solo por necesidad material, sin amor a la obra ni lealtad con los fines de la empresa común, sin vocación verdadera, sin espíritu de gremio o de profesión y sin buenas formas en las relaciones jerárquicas; las creencias y la fe dejan de ser principios originales, irreductibles radiaciones del arcano, potencias de vida fecunda y honda, para ser tomadas como 'mentiras convencionales' o sustituidas por 'doctrinas secretas'; escritores sin mesura ni responsabilidad moral e 'intelectuales' cuya insipiencia carece de frescura y espontaneidad propias del analfabeto de buena cepa, víctimas todos del ejercicio de una falsa libertad, propugnan por doquier especiosas y ruines compensaciones de la luz que ellos han perdido o que no alcanzaron».

La obra escrita de Delgado cubre con riqueza y abundancia todas las áreas de su interés académico, intelectual y humano. Publicó una biografía, Sigmund Freud, en 1927, expre- 
sión de su juvenil entusiasmo por el psicoanálisis y por la obra de su fundador a la que — se ha dicho ya- jamás negó valor histórico ni clínico en el manejo de ciertas condiciones. Con Mariano Iberico, fue coautor de Psicología (1933), libro seminal y de visionaria complejidad dentro de la literatura de habla castellana sobre el tema, con tres ediciones actualizadas en décadas siguientes. En el mismo año, ya en proceso de ruptura con el psicoanálisis y a la manera de un ingreso pleno de convicción en el terreno de la filosofía y la ética, escribió La formación espiritual del individuo. Otra obra histórico-biográfica, Paracelso (1941), consolidó su credo humanístico en el campo médico y en la acción clínica, seguido en 1943, por La personalidad y el carácter, una dilucidación conceptual profunda y a la vez armoniosa de la multifactorialidad de la estructura y el funcionamiento humanos. Otra obra a la vez didáctica y crítica en torno a doctrinas que se asomaban en el campo intelectual de su tiempo y persisten hasta hoy fue Ecología, tiempo anímico y existencia, publicada en 1948. El médico, la medicina y el alma (1952) recogió su apasionado mensaje de integridad en la vocación del profesional, en su consideración del ser enfermo y en la necesidad de no olvidar los componentes psicológico, social, moral y espiritual del ejercicio médico. Se ha mencionado ya su clásico Curso de Psiquiatría, cuya primera edición vio la luz en 1953. En 1962 escribió En torno al alma ajena, donde elaboró ideas acerca de la relación médico-paciente y la distinción entre enfermedad (fallido proceso biológico de adaptación, regulación y defensa), y dolencia (noción de «estar enfermo», impresión perceptiva y emocional que depende de personalidad y temperamento). Dos de sus últimos libros reflejan tal vez, con claridad profética, aspectos cardinales de su obra, plena y elocuentemente suyos: una objetividad crítica que es a la vez demoledora y cabal en Enjuiciamiento de la medicina psicosomática (1960), y una pasión por el saber y la sabiduría legados por figuras de inspiración legendaria, De la cultura y sus artifices (1962). Ambos merecen tal vez un breve examen por separado.

En Enjuiciamiento de la medicina psicosomática, Delgado fustiga el patrón especulativo de los psicosomatistas y reclama un retorno a la sobriedad en la consideración psicodinámica del ser enfermo. Criticó por igual las doctrinas y subdoctrinas que, en ese campo, provenían tanto de Norteamérica (Alexander) como de Europa (von Weiszaker), y propuso no solo una enhiesta textura epistemológica, sino también un mayor campo de acción y una deseable sofisticación metodológica y heurística. En De la cultura y sus artífices, como ya se ha señalado, Delgado presenta una lista imponente de figuras que a lo largo de la historia han marcado rutas imborrables de sapiencia, innovación y progreso intelectual. Delgado quiso así sumarizar su luminoso legado para guía de generaciones futuras.

Si a esta lista inicial sumamos los cerca de 500 artículos científicos, además de ensayos, crónicas, artículos periodísticos, revisiones bibliográficas y recensiones que Delgado publicó en varios idiomas, su obra entraña, sin duda, un monumental carácter de totalidad. A la manera del sabio precepto del quehacer intelectual en la Grecia antigua, puede decir- 
se que «nada de lo humano le fue ajeno». Él integró ciencia y humanismo, conceptualizaciones estrictas, neta terminología científica y legendaria habilidad didáctica. El vigor de su presencia jamás eclipsó el rigor de su trabajo. Fue austero, digno, cordial y generoso, apolíneo y arielista. Delgado dio profundidad y tersura a la psiquiatría, a la ciencia y al conocimiento en el Perú, América Latina y el mundo; acentuó tanto los rigores de la ciencia como las pinceladas del arte y el toque vital de un humanismo pleno; su obra es tallada en granito, racional, crítica, innovadora y visionaria. Se trata de un trabajo hecho con paciencia y tenacidad, basado en convicciones plenas, genuino sello ético y vocación de permanencia. Delgado desempeñó óptimamente no un papel que inventó para sí mismo sino aquel que su destino, su época y su historia le asignaron. Vivió, aun en sus minutos postreros, con la gracia y la dignidad que despojan de amargura a la existencia y hace del buen morir una razón más para la perduración de un vivir ejemplar. Delgado fue durante su vida y hoy ante el juicio de la Historia, un maestro, un peruano universal. 


\section{José Luis Bustamante y Rivero}

(1894-1989)

\section{José Luis SARdóN}





\section{El legado de Bustamante y Rivero}

José Luis Bustamante y Rivero constituye una de las personalidades más destacadas del Perú del siglo XX, debido a la impronta que dejó su conducta como presidente de la República de 1945 a 1948. Pocas veces el Perú ha contado con un gobernante tan respetuoso del estado de derecho y tan desinteresado en obtener beneficio personal alguno de su paso por el poder. Así, aunque fue derrocado por un golpe de Estado, estableció un ejemplo que inspiró la acción política de, por lo menos, tres generaciones siguientes.

Tres agrupaciones políticas peruanas, en efecto, están vinculadas a la trayectoria pública de Bustamante y Rivero. La primera es el Partido Social Republicano, fundado en 1946 por personalidades que participaron en los primeros días de su gobierno —entre ellas, el historiador Jorge Basadre, quien había sido ministro de Educación de su primer gabinete 1 - Esta agrupación buscó dar a Bustamante y Rivero el respaldo partidario del que carecía, tras haberse quebrado el Frente Democrático Nacional que lo llevó al poder.

La segunda es el Partido Demócrata Cristiano, fundado en 1955 por personalidades destacadas de la siguiente generación, que también participaron en su gobierno. De hecho, sus dos líderes principales, Héctor Cornejo Chávez y Luis Bedoya Reyes, fueron muy cercanos colaboradores de Bustamante y Rivero. Este partido trató de estructurar políticamente la ideología social cristiana, que Bustamante y Rivero había promovido².

Finalmente, la tercera es el Frente Democrático (Fredemo), que lanzó a la presidencia de la República al escritor Mario Vargas Llosa, de la generación subsiguiente, en 1990. Desde su nombre, esta alianza —integrada por Acción Popular, el Partido Popular Cristiano y el Movimiento Libertad- evocaba al Frente Democrático Nacional de 1945. El Fredemo — sobre todo, el Movimiento Libertad— hizo más hincapié que Bustamante y Rivero respecto a la necesidad de delimitar mejor el rol del Estado en la economía. Sin embargo, sí compartió plenamente la preocupación de este por la afirmación del estado de derecho en el Perú3.

1 Cfr. Basadre 1986 [1946]: 57-60.

2 Cfr. Rey de Castro 1985.

3 Cfr. Vargas Llosa 1993: 21. 


\section{LAS ELECCIONES DE 1945}

José Luis Bustamante y Rivero fue elegido presidente de la República en las elecciones de 1945 con una extraordinaria votación que alcanzó 67\% de los votos válidos. Como ya se dijo, fue el candidato presentado por el Frente Democrático Nacional, alianza que se apoyaba en un trípode constituido por el APRA, el mariscal Óscar R. Benavides y un grupo de personalidades independientes, entre las que destacaban arequipeños como Julio Ernesto Portugal y Manuel J. Bustamante de la Fuente ${ }^{4}$.

Varios factores explican este singular triunfo electoral. En lo inmediato, resultó importante el que, poco antes de aceptar la candidatura del Frente, Bustamante y Rivero hubiera declinado la candidatura oficialista que le ofreció el presidente Manuel Prado Ugarteche, argumentando que el poder no se podía recibir en una «bandeja de plata». Esto constituyó un gesto de desinterés personal que generó una corriente de simpatía en la opinión pública 5 .

Adicionalmente, dicho triunfo también se explica porque el Frente logró una feliz aunque finalmente breve- amalgama de fuerzas políticas disímiles, ideológica y culturalmente. El APRA y el mariscal Benavides estaban en la extrema izquierda y en la extrema derecha del espectro ideológico de entonces. Sin embargo, esta tensión se resolvía gracias a la postura moderada del grupo independiente.

Por otro lado, aunque tenía proyección nacional, el líder del APRA, Víctor Raúl Haya de la Torre, era un trujillano por sus cuatro costados; mientras tanto, la tercera pata del Frente provenía mayormente de Arequipa. En este caso, la participación del mariscal Benavides resolvía dicha tensión, haciendo viable la alianza victoriosa. Lamentablemente, su muerte, días antes de que Bustamante y Rivero asumiera la presidencia de la República, determinaría el fin del Frente.

En todo caso, la explicación fundamental del éxito electoral de Bustamante y Rivero radicó en su propia personalidad. José Luis no solo había declinado la candidatura oficialista sino que, a sus cincuenta y un años de edad, contaba con una importante trayectoria pública. Había sido autor del «Manifiesto» de Arequipa, enarbolado por el movimiento social que puso fin al Oncenio, régimen del presidente Augusto B. Leguía, en $1930^{6}$. Asimismo, se desempeñó como ministro de Justicia e Instrucción del gobierno transitorio siguiente, alejándose del mismo cuando empezó a tomar un cariz autoritario.

4 Cfr. Bustamante de la Fuente 1955.

5 Cfr. Basadre 1975: 645-726. Asimismo: Chirinos Soto 1982: 504-506. También: Tuesta Soldevilla 1994 [1987]: 229-233. Allí puede verse que el mayor respaldo provino de: 1. La Libertad (84\%), 2. Pasco (81\%), 3. Callao (79\%) y 4 . Arequipa (75\%).

6 Cfr. Bustamante y Rivero 1996 [1930]: 239-243. 


\section{LA HERENCIA Y EL MEDIO}

José Luis Bustamante y Rivero nació el 15 de enero de 1894 en Arequipa, en el seno de una familia de prominentes hombres de Derecho. Entre ellos, destaca su abuelo paterno, Pedro José Bustamante y Alvizuri, quien fue presidente de la Corte Superior de Arequipa, de gran prestigio en el ámbito jurídico del país. Fue también colaborador cercano de Ramón Castilla y llegó a ser presidente de la Cámara de Diputados en $1858^{7}$.

Bustamante y Alvizuri estuvo casado con Salomé Barreda y García, con quien tuvo nueve hijos. El sétimo de ellos, Manuel Bustamante y Barreda, siguió sus pasos como magistrado de la Corte Superior de Arequipa. Casado con Victoria Rivero y Romero, tuvo también nueve hijos, el tercero de los cuales sería el futuro presidente de la República, José Luis Bustamante y Rivero. En 1923, este formó su propia familia, al casarse con María Jesús Rivera, con quien tuvo dos hijos, Beatriz y José Luis.

Bustamante y Rivero estudió en el Colegio San José, de padres jesuitas, en Arequipa, siendo excelencia en la promoción de 1910. Posteriormente, estudio Letras y Derecho en la Universidad de San Agustín, donde se recibió como doctor en Jurisprudencia en 1918. Finalmente, estudió también Ciencias Políticas y Económicas en la Universidad San Antonio Abad, del Cusco, donde se recibió como doctor en estas materias en $1929^{8}$.

Durante su juventud, Bustamante y Rivero desarrolló una intensa labor intelectual, siendo cercano al grupo de escritores arequipeños El Aquelarre, en el que destacaban César Atahualpa Rodríguez y Percy Gibson. Publicó numerosos artículos y escritos literarios en los diarios El Deber de Arequipa y El Comercio del Cusco, haciéndose conocido en el ámbito literario y periodístico. De esos años, data su célebre poema "Ciudad que fue», cuyos primeros versos son todavía recitados con devoción en Arequipa:

Esas casas viejas de las calles solas, esas casas viejas y destartaladas en que la carcoma de los años idos desunió las tejas y horadó los nidos $[\ldots]$

\section{LABORES PROFESIONALES}

Bustamante y Rivero se recibió como abogado en 1919, y se dedicó a la especialidad de derecho civil. Entre las actividades que desarrolló como abogado, destaca su condición de asesor legal de la Municipalidad de Arequipa y de los sindicatos ferroviarios de la misma

7 Cfr. Congreso de la República del Perú 1999.

8 Cfr. Arce Espinoza 2003. 
ciudad, siempre ad honórem. Esta vinculación con los sindicatos, por cierto, despertó sospechas de inclinación izquierdista en los círculos empresariales arequipeños, a los que prestaba también servicios de asesoría legal.

Simultáneamente a la práctica del derecho, Bustamante y Rivero desarrolló también una intensa actividad docente, primero en el Colegio Seminario y luego en la Universidad de San Agustín. Allí dictó diferentes materias, primero en las áreas de Letras y Ciencias Sociales, y luego en la de Derecho. Sus alumnos de entonces lo recordarían siempre de una manera entrañable, como un maestro distinguido, muy cuidadoso en la presentación de sus lecciones.

En esas circunstancias de despegue profesional y académico se encontraba Bustamante y Rivero cuando se desataron los dramáticos acontecimientos que marcaron el final del Oncenio, en agosto de 1930. El rol protagónico que tuvo en esta coyuntura —mencionado en líneas anteriores - le dio una gran proyección nacional, que resultaría luego la antesala de su llegada a la presidencia de la República en 1945.

$\mathrm{Al}$ alejarse del gobierno de transición, Bustamante y Rivero retornó a sus actividades privadas en Arequipa. Sin embargo, al cabo de unos años, en 1934, ingresó a la carrera diplomática, como ministro plenipotenciario del Perú en Bolivia. Luego, desempeñó el mismo puesto en Uruguay, volviendo finalmente, en 1942, a Bolivia, ya nombrado como embajador del Perú. En esta situación, le fueron ofrecidas las candidaturas oficialista y de oposición para la presidencia en 1945.

En los diez años que actuó como miembro del servicio diplomático peruano, Bustamante y Rivero participó en importantes conferencias internacionales sobre temas de derecho y política latinoamericana, presentando ponencias de una marcada inspiración social cristiana, siempre con una impronta literaria innegable. Así, Bustamante y Rivero se fue perfilando como jurista, ideólogo y pensador de temas sociales.

\section{Presidente de la República}

José Luis Bustamante y Rivero asumió la presidencia de la República el 28 de julio de 1945, en medio de una situación política difícil, al haber el APRA declinado su ofrecimiento de designar a dos de los nueve ministros que entonces componían el gabinete. El APRA argumentó que "prefería concentrar por el momento su actividad en la función parlamentaria y mantenerse como 'observador' de la política del Ejecutivo»'. Esto significaba que pasaba a la oposición y que, por tanto, se quebraba el Frente Democrático Nacional.

La no participación del APRA en el gobierno que había contribuido a elegir tiene distintas explicaciones. Por el lado del APRA, se ha insistido en que el ofrecimiento de dos

9 Cfr. Bustamante y Rivero 1949: 28-29. 
carteras ministeriales era claramente insuficiente, a la luz de su contribución electoral ${ }^{10}$. Sin embargo, los largos años que estuvo fuera de la ley, durante los gobiernos de Óscar R. Benavides y Manuel Prado Ugarteche, seguramente generaron también una impaciencia muy grande en el APRA por hacerse del poder, haciéndole olvidar que el triunfo de Bustamante y Rivero no fue solo obra suya.

Además, como señalaría luego Enrique Chirinos Soto: «Uno de los motivos determinantes del fracaso del experimento democrático que se inicia en 1945 es la manifiesta incompatibilidad psicológica entre Bustamante y Haya. Bustamante es introvertido. Haya, extrovertido. Bustamante es de Arequipa. Haya, de Trujillo. [...] Bustamante es hombre de gabinete. Haya es conductor de multitudes. Intelectualmente, el género de Bustamante es la prosa poética o el análisis jurídico. El de Haya es la oratoria. Bustamante está mejor que nunca cuando escribe. Haya, cuando habla» ${ }^{11}$.

El alejamiento del APRA, en todo caso, no inhibió la participación de personalidades independientes en el gobierno. Además del ya indicado Jorge Basadre, el primer gabinete — presidido por Rafael Belaunde— incluyó también a Luis Alayza y Paz Soldán en Justicia, a Óscar Trelles en Salud y a Rómulo Ferrero en Hacienda. En los gabinetes siguientes, Bustamante y Rivero convocó a profesionales no menos destacados, como Honorio Delgado, Luis Echecopar García, Enrique García Sayán, José León Barandiarán y Luis E. Valcárcel. En conjunto, Bustamante y Rivero supo rodearse de gente de primera línea.

\section{ECONOMÍA Y POLÍTICA}

La difícil situación política, configurada al inicio del gobierno de Bustamante y Rivero, complicó el adecuado enfrentamiento de los problemas económicos y financieros que enfrentaba el Perú. Bustamante y Rivero recibió un país con déficit fiscal, inflación y un Estado cada vez más intervencionista en la economía. Entrampado por su enfrentamiento con el Congreso, su gobierno pudo emprender el camino de la estabilización monetaria y la liberalización económica recién en 1948, poco antes de ser derrocado.

Como ha recapitulado Gianfranco Bardella, en 1939, con la coartada del estallido de la Segunda Guerra Mundial, el gobierno del general Óscar R. Benavides dictó leyes que autorizaban controles de precios en productos básicos y alquileres. El gobierno siguiente, de Manuel Prado Ugarteche, expandió los controles, en 1942, al tipo de cambio. Finalmente, a inicios de 1945, el intervencionismo estatal incluyó a las importaciones y al comercio exterior. Estas medidas generaron el decaimiento, si no la paralización, de la actividad económica ${ }^{12}$.

10 Cfr. Basadre 1975: 696-697. También: Sardón 1987: 10-14; y Sánchez 1987 [1969]: 366-368.

11 Cfr. Chirinos Soto 1982: 509.

12 Cfr. Bardilla 1989: 352-355. 
Además, dichos gobiernos establecieron subsidios para determinados productos alimenticios. La expansión del crédito, que se implementó para sostener tal política, generó un incremento anual promedio de los precios de 10,7\% de 1939 a 1944. Para enfrentar esta situación, el primer ministro de Hacienda de Bustamante y Rivero, Rómulo Ferrero, propuso un plan de control del gasto y el endeudamiento públicos ${ }^{13}$. Sin embargo, tal propuesta fue criticada por varios senadores del Frente, provocando su renuncia.

Solo en los que resultarían sus últimos meses de gobierno — con Rómulo Ferrero nuevamente a cargo de Hacienda - el gobierno empezó la liberalización del tipo de cambio y la eliminación de los subsidios. Sin embargo, el hipo en los precios que produjeron tales medidas terminó por abonar el terreno para el golpe de Estado. Encabezado por el general Manuel A. Odría, quien había sido su ministro de Gobierno, este se realizó el 27 de octubre de 1948.

El golpe fue alentado y financiado por la oligarquía feudal crispada por los impasses del gobierno y el Congreso, y más ampliamente de Bustamante y Rivero y el APRA. Le reprochaba al presidente haberse aliado al APRA, olvidando el detalle de que tal alianza había sido fundamental para su triunfo en las elecciones. En todo caso, al conocer la noticia del golpe, el poeta Martín Adán dijo: «El Perú ha vuelto a la normalidad».

\section{Destierro y RETORNO}

Producido el golpe de Estado, José Luis Bustamante y Rivero fue deportado a Buenos Aires, Argentina. Allí inició un largo destierro y vivió una situación difícil, ya que no percibía la pensión que legalmente le correspondía. Sobrevivió gracias al apoyo de familiares y amigos, y a trabajos ocasionales. En los primeros momentos del destierro, redactó el libro Tres años de lucha por la democracia en el Perú, en el que explicaba los dramáticos acontecimientos ocurridos ${ }^{14}$.

Bustamante y Rivero permaneció en Buenos Aires solo los primeros ocho meses. Luego se trasladó a Santiago de Chile, donde su esposa se estaba atendiendo por un accidente ocurrido en Antofagasta, cuando viajaba hacia Buenos Aires. Al cabo de seis meses, Bustamante y Rivero y su esposa viajaron a Nueva York, donde ella fue sometida a una segunda operación. Pasaron los cinco años restantes del destierro en Madrid y Ginebra.

A pesar de reiterados intentos durante los años siguientes, Bustamante y Rivero no pudo regresar al Perú, ya que el gobierno de Odría le aplicó la tristemente célebre Ley de Seguridad Interior de la República. En todo caso, en noviembre de 1955, alentado por la proximidad del cambio de gobierno, Bustamante y Rivero planteó un recurso de hábeas corpus, a través de su abogado Luis Bedoya Reyes.

13 Cfr. Salazar Larraín 1994: 8.

14 Cfr. Bustamante y Rivero 1949. 
Este recurso fue presentado ante el Segundo Tribunal Correccional de la Corte Superior de Lima, que presidía Domingo García Rada ${ }^{15}$. Pese a haber sido nombrado por el gobierno de Odría, García Rada emitió un valiente voto singular, declarando fundado el recurso legal. Aunque los votos de los otros dos vocales fueron por la improcedencia, el voto singular tuvo gran impacto en la opinión pública. No tardaría el gobierno en permitir el retorno de Bustamante y Rivero.

El 9 de febrero de 1956, habiendo transcurrido más de siete años después de su deportación, Bustamante y Rivero regresó al Perú, y fue recibido por una multitud de simpatizantes. En el mitin realizado luego en la plaza San Martín de Lima, Bustamante y Rivero pronunció un emocionado discurso. Situación similar vivió poco después en la Plaza de Armas de Arequipa. No pudo ser más cálido el recibimiento.

\section{JUEZ Y ÁRBITRO INTERNACIONAL}

En las tres décadas finales de su vida, Bustamante y Rivero recogió abundante cosecha del prestigio profesional y personal ganado en sus actividades académicas, profesionales y políticas. De 1960 a 1969, por lo pronto, se desempeñó como juez de la Corte Internacional de Justicia de La Haya, en Holanda, principal órgano de administración de justicia de las Naciones Unidas. De 1967 a 1969, presidió esta Corte, donde dejó un muy grato recuerdo.

Posteriormente, en las décadas siguientes, ya retirado de esta labor, tuvo delicados encargos profesionales para resolver conflictos internacionales. El más importante de estos lo recibió en 1980, cuando Honduras y El Salvador le solicitaron su mediación para resolver una antigua disputa territorial. La solución que planteó Bustamante y Rivero fue plenamente satisfactoria para las partes, al punto que fue propuesto al Premio Nobel de la Paz.

Conjuntamente con estas actividades de juez, mediador y árbitro internacional, Bustamante y Rivero mantuvo una vigilante atención del proceso político peruano, pronunciándose sobre este cuando las circunstancias lo requerían. Especialmente significativo fue su rechazo a la estatización de la prensa realizada en 1974 por el gobierno del general Juan Velasco: «Gobierno es un vocablo que indica y entraña una bilateralidad consciente de voluntades: gobernantes y gobernados. Si esa bilateralidad no funciona, no hay gobierno posible; habrá, sencillamente, dos elementos dislocados, el orden de mando y la obediencia impuesta. En total, el absolutismo» ${ }^{16}$.

Diez años después, desempeñándose como senador vitalicio, se opuso a que el Perú firmara la Convención de las Naciones Unidas sobre el Derecho del Mar, pues implicaba

15 Cfr. García Rada 1978: 172-191.

16 Cfr. Bustamante y Rivero 1949: 293. 
cercenar las doscientas millas de mar territorial que su gobierno había reivindicado el 1 de agosto de 1947, con amplio respaldo de la comunidad internacional. Al hacer suya la postura de Bustamante y Rivero, el Perú quedó, por cierto, en la importante compañía de Estados Unidos.

José Luis Bustamante y Rivero falleció en el Hospital Militar de Lima, el 11 de enero de 1989, al borde de los noventa y cinco años de edad. Aunque el país pasaba entonces por un momento especialmente difícil, sus exequias expresaron el profundo respeto que había llegado a merecer por parte de toda la ciudadanía.

\section{BALANCE TENTATIVO}

Casi dos décadas han pasado ya de su partida. Visto a esa distancia, sin embargo, Bustamante y Rivero mantiene intacta la talla de patricio republicano que le fuera reconocida en sus años finales ${ }^{17}$. Evidentemente, no se trató de una persona que buscó el poder. Ocurrió, simplemente, que se encontró con él —en 1930 primero y en 1945 después—, debido a que especiales circunstancias en la política peruana hicieron atractivo su perfil de hombre de derecho.

Ya en el poder, su preocupación central fue, claramente, consolidar al estado de derecho en el Perú. En el mismo escrito antes citado, respecto a la libertad de expresión, Bustamante y Rivero brindó una perspectiva del mismo que coincidiría perfectamente con la de una de los grandes pensadores liberales del siglo XX, Friedrich A. Hayek: «Lo que hace falta en toda época y bajo cualesquiera circunstancias es un ordenamiento legal, una pauta preestablecida, un gobierno sin sorpresas, una posibilidad de apelación democrática ajena al capricho de los hombres, que señale lo razonable, lo prudente, lo justo. Y luego, el libre diálogo, la vida sin temor ${ }^{18}$.

Por lo demás, no debe olvidarse tampoco que, dentro de las difíciles circunstancias políticas en las que actuó, buscó establecer una economía sana, liberalizando precios y eliminando subsidios. Estas políticas fueron iniciativa de su ministro de Hacienda, Rómulo Ferrero, pero fue Bustamante y Rivero quien les dio sostén político. En la década siguiente, gracias a ellas —mantenidas y profundizadas por los dos gobiernos siguientes—, el Perú emprendería una etapa de crecimiento.

Por ello, aunque su pensamiento político y económico estuviera siempre teñido de un pathos social cristiano, puede afirmarse que — dado su amor a la ley y su rechazo al abuso, a la arbitrariedad y al capricho- pocos hombres contribuyeron tanto como José Luis

17 Cfr. Sardón 1989: 13.

18 Cfr. Bustamante y Rivero 1949: 296. El ideal hayekiano del estado de derecho está expuesto, sobre todo, en HAYEK, Friedrich A. (1973 y 2006) Derecho, legislación y libertad: una nueva formulación de los principios liberales de la justicia y de la economía política, edición en español, en dos versiones: Madrid: Unión Editorial, 1973, y Guatemala: Universidad Francisco Marroquín, 2006. 
Bustamante y Rivero a la causa de la libertad en el Perú. Por ello mismo, los peruanos, de su tiempo y del nuestro, mantenemos vivo su recuerdo.

\section{Bibliografía}

ARCE ESPINOZA, Mario Rommel (2003). «Bustamante y Rivero». En: diario Arequipa al Día. Arequipa: 17 de noviembre.

BARDILLA, Gianfranco (1989). Un siglo en la vida económica del Perú: 1889-1989. Lima: Banco de Crédito del Perú.

BASADRE, Jorge y otros (1986 [1946]). «Manifiesto del Partido Social Republicano». En: Debate, sétimo año, número 42, pp. 57-60.

(1975). La vida y la historia, segunda edición. Lima: sin editor.

BUSTAMANTE DE LA FUENTE, Manuel J. (1955). Mis ascendientes. Lima: edición privada.

BUSTAMANTE Y RIVERO, José Luis (1996 [1930]). El mensaje cívico de José Luis Bustamante y Rivero. Lima y Arequipa: Fundación M. J. Bustamante de la Fuente e Instituto del Sur.

(1949). Tres años de lucha por la democracia en el Perú. Buenos Aires: sin editor.

CHIRINOS SOTO, Enrique (1982). Historia de la República. Perú, 1821-1982, segunda edición. Lima: Minerva.

CONGRESO DE LA REPÚBLICA DEL PERÚ (1999). Conociendo el Congreso. Lima: Fondo Editorial Congreso del Perú.

GARCÍA RADA, Domingo (1978). Memorias de un juez. Lima: Andina.

HAYEK, Friedrich A. (1973 y 2006). Derecho, legislación y libertad: Una nueva formulación de los principios liberales de la justicia y de la economía política, edición en español, en dos versiones: Madrid: Unión Editorial, 1973, y Guatemala: Universidad Francisco Marroquín, 2006.

REY DE CASTRO, Jaime (editor) (1985). Testimonio de una generación: los social cristianos. Lima: Centro de Investigación de la Universidad del Pacífico (CIUP).

SALAZAR LARRAÍN, Arturo (1994). Rómulo A. Ferrero: pensamiento y acción, tomo I. Lima: Instituto de Economía de Libre Mercado.

SÁNCHEZ, Luis Alberto (1987 [1969]). Testimonio personal, tomo II, «El purgatorio 1931-1945», segunda edición. Lima: Mosca Azul.

SARDÓN, José Luis (1987). «El zorro de arriba. Entrevista a Luis Alberto Sánchez». En: revista Debate. Lima: marzo-abril, 9(43), pp. 10-14.

(1989). «El gran patricio». En: El Comercio, suplemento «Dominical». Lima: 5 de marzo, p. 13. 



\section{Pedro G. Beltrán}

\section{(1894-1979)}

Arturo Salazar Larraín 



\section{LA PARADOJA NACIONAL}

Pedro G. Beltrán murió a los ochenta y cinco años de edad. Su sepelio, como su propia vida, constituyó también un abierto desafío a las dictaduras gobernantes. En esa oportunidad no fue él, sino los trabajadores de La Prensa (que había refundado y revolucionado), quienes desafiaron al gobierno militar sacando el féretro de Beltrán de la iglesia donde se velaba para llevarlo, en hombros y por las calles de la ciudad, hasta el local del diario, entre aplausos de los sorprendidos transeúntes.

¿Cómo es que una persona, a la que en el Perú se había pintado con los peores colores que uno pueda imaginar (cavernario, golpista, decimonónico y hambreador, entre otros), merecía semejante homenaje de los peruanos? Para entender esa paradoja nacional solo cabe una explicación: a Beltrán lo conocían quienes lo trataban y escuchaban; lo desconocían, en cambio, quienes, con facilidad y hasta complacencia, recogían aquellas versiones que la pasión personal, o el antagonismo político, suelen fabricar febrilmente en nuestro país.

El propio Beltrán contribuyó a esa «leyenda negra» al negarse sistemáticamente a responder los ataques y las versiones antojadizas que sus antagonistas, de la izquierda y de la derecha, le achacaron constantemente, sin obtener de él respuesta alguna. Don Pedro justificaba esa conducta mediante el siguiente raciocinio: «Si yo me dedico a contestar las versiones caprichosas y los infundios de los que no me quieren, gasto mi tiempo en contestar lo que ellos quieren que conteste, dejando de lado lo que yo quiero y debo contestar y hacer».

Fue necesario que pasaran treinta años de actividad pública para que Pedro G. Beltrán se animara a contestar esos infundios. En abril de 1978 César Hildebrandt, en Caretas $^{19}$, entrevistó a Beltrán. Fue una de aquellas entrevistas en las que César estudia y revisa la historia del entrevistado y recoge lo que se dice y se comenta sobre él. Lo hizo entonces desde su perspectiva de periodista y hombre de izquierda. Hildebrandt confesó después, ante un grupo de colegas, que de todos los entrevistados que tuvo, el más «respondón» y el más difícil de todos fue Pedro G. Beltrán.

19 Cfr. Hildebrandt 1978. 
Para Beltrán, desbaratar los infundios era perder el tiempo. Sin embargo, debido a ello tuvimos los peruanos que pagar el precio de las penumbras que se tejieron alrededor de él, así como de sus tesis económicas y sociales. Con ello, se tuvo que postergar por treinta años la comprensión del pensamiento económico que traía consigo y que hoy se practica en el mundo entero, incluyendo a la antigua Unión Soviética, Vietnam y China comunista.

\section{LOS PERGAMINOS ACADÉMICOS}

Al término de su secundaria, Beltrán ingresa a la Universidad Nacional Mayor de San Marcos (Facultad de Letras) y, poco después, reorienta su vocación y su entusiasmo hacia los estudios de economía. Para ello, postula y logra ingresar a la mundialmente conocida London School of Economic and Political Science, donde, en 1918, obtiene su grado académico. Regresa inmediatamente al Perú a predicar la buena nueva de la economía de mercado y a combatir la inflación como el peor de los males contemporáneos. Percibe entonces la estafa política que hay detrás de la emisión inorgánica de billetes y empieza, poco a poco, a adquirir enemistades políticas y personales.

La claridad de su pensamiento económico y sus conocimientos teóricos y prácticos en esas materias le permiten contraer amistad, supuestos teóricos y comunidad de ideas con economistas de la talla de Ludwig von Mises, Friedrich Hayek, Milton Friedman, Wilhelm Röpcke y Ludwig Erhard, entre otros; a quienes el nombramiento de Beltrán como primer ministro y ministro de Hacienda en el Perú los lleva a enviar efusivas felicitaciones escritas y buenos augurios para la economía peruana. Mises, a la sazón en Nueva Hampshire, enterado de la noticia del nombramiento de Beltrán, declara a la agencia noticiosa AFP que «Beltrán es paladín incansable de la libertad política y económica. Lo que más le hace falta al Perú en estos momentos — prosigue — es una moneda estable y un clima político que sirva para crear condiciones que produzcan una mejoría constante en el nivel de vida del pueblo».

Es difícil imaginar que un ministro peruano pudiera haber convocado, como convocó Beltrán, el elogio de economistas universales como Mises y de premios Nobel de Economía como Friedrich Hayek y Milton Friedman ${ }^{20}$. Beltrán no midió el espaldarazo académico e intelectual que significaron los juicios y elogios de esos personajes porque le parecía que correspondían a una verdad que todos compartían. Cuando el ministro Beltrán es interpelado en el Senado sobre la política económica que proponía y las medidas para evitar el control de precios, su respuesta fue contundente: «Tengo ideas definidas sobre esta clase de enfermedad [la inflación] porque le he dedicado a su estudio toda la

20 Estaba yo a cargo de la correspondencia y el despacho de prensa. 
vida [...] y porque quiero aclarar ahora que sé lo que hago, que sé adónde voy y sé cómo lograrlo. En esta labor, no se recogen aplausos si no se muestran resultados ${ }^{21}$.

¡Beltrán mostró resultados abundantes e inmediatos! Pero no recibió aplausos sino críticas e improperios. La ceguera política, y la ignorancia en los temas económicos, se conjuraron para convertir en pecado mortal sus ideas económicas, hasta que la caída de la Cortina de Hierro hizo ver el error de la economía controlada y el acierto de la libertad que había predicado en el Perú, décadas atrás, Pedro G. Beltrán.

\section{LA REVOLUCIÓN DE LA MONEDA}

La obsesión de Beltrán fue la inflación y la forma de combatirla. Los economistas de su entorno habían estudiado y analizado ese fenómeno desde sus raíces. Beltrán, desde Londres, regresó al Perú pertrechado de una visión amplia y clara, tanto académica como política, de lo que era y significaba la emisión inorgánica de billetes. Podría decirse —si no fuera por su probada vocación periodística— que Beltrán predicó, creó diarios y revistas y participó en ellos casi exclusivamente para sembrar la alarma social de la inflación en el corazón mismo del Perú y los peruanos.

En cuanto a la versión que se daba entonces — y en estos días también — de la «inflación importada» (es decir, de una causa externa que determina la elevación de los precios), Beltrán es enfático:

Eso que dicen, que [la inflación] se debe a lo que pasa en el mundo, es un disparate. La solución (para contener el alza de precios) no solo es parar la emisión de billetes: es preciso también cortar el dispendio, el gasto innecesario, el gasto que es posible no hacer.

La inflación es el resultado de imprimir billetes. Eso, en una época se llamaba la maquinita. Ahora se llama programa de los medios de pago. Ya no pronuncian la palabra billete [...]. En tiempos de Odría las papas subieron a cuatro soles y alguien me ha dicho que durante este régimen [militar] ese precio llegó a dieciséis y dieciocho soles $^{22}$.

En su último trabajo, ¿Y ahora, qué? (de poco antes de su muerte), Beltrán regresa al tema de toda su vida: la inflación, la impresión de billetes y la maquinita. Beltrán no se dejaba atrapar nunca por las palabras difíciles ni por los conceptos enredados de los economistas estructuralistas adictos al régimen militar; él estaba mucho más al día en la ciencia económica y en la información especializada que casi todos sus antagonistas.

21 Sesión del Senado de la República del 5 de febrero de 1960.

22 Cfr. Hildebrandt 1978. 
Pensaba de ellos, como en Francia Mirabeau pensó de sus colegas de la Asamblea Nacional, que eran «geómetras del Estado con la cabeza llena de fórmulas luminosas, tan luminosas, que los ofuscan para el simple trato con las cosas»" Decía Beltrán que esas «cosas» - el costo de vida y el ajuste del presupuesto- las saben en mejor las amas de casa que los economistas y los políticos.

En ¿Y ahora, qué?, Beltrán hace la siguiente reflexión sobre el impacto que causó la inflación durante el Gobierno Revolucionario de la Fuerzas Armadas (1968-1980). Comienza por estimar la emisión (impresión) de billetes previa a la instalación del Gobierno Revolucionario de las Fuerzas Armadas en trece mil millones de soles. La emisión correspondiente a 1978 (año en que Beltrán escribe el folleto) fue, en cifras redondas, de ciento cincuenta mil millones, lo que arroja la diferencia de ciento treinta y siete mil millones netos de soles emitidos.

«Esto quiere decir — aclara Beltrán— que, de cada cien soles en circulación, S/. 91,30 fueron fabricados por la dictadura militar, mientras que el saldo de $S / .8,70$ fue emitido antes de que la revolución de la Fuerza Armada tomara el poder».

Son estos los soles solitarios, de valor real, que constituyen el único bastión del valor de la moneda, en tanto su expansión no esté respaldada con nuevos bienes y servicios producidos. Beltrán llega entonces a las siguientes conclusiones:

Aunque hay ahora once veces y media más dinero que en 1968, los peruanos no vivimos hoy once veces y media mejor que entonces. Ni siquiera (aun tomando en cuenta el aumento de la población) vivimos hoy ocho y media veces mejor que en 1968; ni cuatro veces, ni dos veces, ni una vez y media. Ni siquiera vivimos igual que antes; vivimos peor que antes de la revolución.

\section{LA REVOLUCIÓN EN EL AGRO}

Beltrán fue siempre un inconforme. Exploró todas las posibilidades de cambiar las cosas. Antes de Vito Dumas, fue navegante solitario en las aguas del Pacífico. Igualmente, exploró el vértigo de la velocidad y la capacidad de los vehículos para desarrollar velocidades máximas, lo que mundialmente se ha convertido hoy en un deporte de multitudes. Cuando, a principios de siglo, regresó al Perú para asumir la administración del fundo familiar en Cañete, no vaciló en practicar su habilidad de piloto civil con el propósito de inaugurar en nuestro país la fumigación aérea en el cultivo del algodón.

23 La alusión a Mirabeau se encuentra en Ortega y Gasset 1963: 111. 
Asumió la presidencia de la Sociedad Nacional Agraria para impulsar el mejoramiento y la tecnificación de los cultivos en el Perú. Ochenta años antes (en 1928) había promovido la instalación de las primeras estaciones experimentales en los principales valles del país. Era de lógica elemental suponer que en climas tan variados como los nuestros era indispensable contar, en cada zona, con una estación experimental agrícola que facilitara a los agricultores locales la información, condiciones de clima, mejoramiento de suelos y otros, que les ayudaran a orientar sus sembríos, así como la adopción de las técnicas adecuadas a cada zona del país.

El primer proyecto que logra concretar es la Estación Experimental Agrícola de La Molina, ubicada en los terrenos de lo que fue la Hacienda La Molina ${ }^{24}$. Esta se convirtió después en local de lo que es hoy la Universidad Nacional Agraria. Años más tarde, Beltrán es elegido presidente de la Asociación de Agricultores del valle de Cañete, la misma que, bajo su impulso, promueve la mecanización integral de la agricultura de la zona. Por encima de ello, el afán de modernizarlo todo y de ir a las causas primeras de los problemas de productividad agrícola, lo lleva a crear y desarrollar la Estación Experimental de Cañete, para la cual logra la aprobación de un autogravamen al quintal de algodón desmotado de exportación. Se trata de un financiamiento directo y consentido por los productores-exportadores de algodón para fines de investigación agrícola, con dos finalidades inmediatas:

a) que en el manejo de los fondos de esa institución se eviten las trabas o intervención maliciosa de los políticos y gobernantes. Fueron estos políticos quienes llegaron al extremo de endosar a esos agricultores el título de «barones del algodón».

b) que se abra un campo insospechado de mejoramiento y modernización en la agricultura peruana, que Beltrán aprovecha al máximo.

Para dirigir ese nuevo centro de investigación Beltrán llama al mejor genetista agrícola existente, ingeniero Teodoro Boza Barducci. No le importó que este tuviera simpatías o filiación aprista. Beltrán jamás puso por delante nada que no fuera capacidad y eficiencia en las personas a quienes confiaba una tarea. Fue lo mismo - y aun más notorio-cuando en la siguiente década emprendió con La Prensa su revolución periodística. Alejandro Valle Palomino (Romualdo), poeta de clara filiación comunista, recientemente fallecido, trabajó en ella como caricaturista de la página editorial. Poco antes, Romualdo había caricaturizado en una revista a Beltrán como un crucificado, bajo el título de «El Señor de los Milagros». Entre los redactores y periodistas hubo casos similares. Beltrán no confundía trabajo con ideología.

24 Cfr. Sociedad Nacional Agraria 1928. 
Con Teodoro Boza Barducci emprendió en Cañete reformas radicales en cuanto a rendimientos, productividad y saneamiento agrícola: sembrío de insectos que se alimentan de los insectos depredadores del algodonero, mayor distanciamiento entre surco y surco para permitir que la luz del sol impida los pozos y charcos de agua estancada, favorables a la reproducción de los insectos malignos, así como otros procedimientos por el estilo ${ }^{25}$.

Con el mismo Boza Barducci, Beltrán proyectó la necesidad de cambiar progresivamente el casi monocultivo del algodonero del valle de Cañete, sometido ya el algodón a las fluctuación de precios en el mercado internacional y a su sustitución por las nuevas fibras textiles. Y comenzó con una planeada serie de viajes de Boza Barducci a las zonas paperas de la sierra peruana, para obtener semillas capaces de aclimatarse al área costeña de Cañete. Como se sabe, Lima se abastece de papa, en gran parte, procedente de Cañete.

La visión temprana para exportar productos del agro peruano al mercado estadounidense indujo a Beltrán al mejoramiento genético del lúcumo hasta lograr, tras pacientes cruces, notables rendimientos por rama. Tenía en mente la demanda de esencias frutales del inmenso mercado de helados de Estados Unidos. La Cooperativa Tercer Mundo, a la que el gobierno militar dio la propiedad del fundo de Beltrán, se encargó de liquidar esa oportunidad talando los lúcumos que habían costado muchos años de dedicación y esfuerzo. Constituye un absurdo haber llamado conservador a quien, a todas luces, no tuvo otra aspiración que cambiar lo que consideraba viejo y obsoleto. No hubo campo de acción donde Beltrán no hubiera empujado, con lúcida vehemencia, el cambio funcional. Beltrán solía decir que era «un agricultor pata en el suelo» para significar que era un hombre de campo que conocía el campo tanto como la palma de sus manos.

\section{LA REVOLUCIÓN PERIODÍSTICA}

Luchar contra la inflación y vivir en una sociedad en la que impere la libertad y prevalezca la verdad sobre la impostura, el mercado sobre el control y la sensatez sobre la política requería medios de comunicación masiva que ayudaran a formar en la sociedad peruana esa fuerza interior que llamamos opinión pública. El predicador, por lo demás, necesita siempre de púlpito para predicar.

Fue así como germinó en Beltrán el proyecto de un diario capaz de hacer llegar a los peruanos las verdades que traía consigo y la necesidad de libertad para los peruanos. Había confesado en una entrevista de 1978 sobre la dictadura militar que la encontraba todavía instalada en el Perú: «Lo que me da mucha pena es ver que el pobre Perú, mi Perú, mi Perú, mi patria, no tenga siquiera libertad de prensa ${ }^{26}$.

25 De un reportaje publicado en La Prensa al ingeniero Boza Barducci.

26 Cfr. Hildebrandt 1978. 
Fue el mismo sentimiento y la misma necesidad que, poco más de cuarenta años atrás, lo habían llevado a reunir a un grupo de amigos y empresarios para recobrar el diario $L a$ Prensa, fundado por Pedro de Osma, incautado durante varios años por el gobierno de Leguía y devuelto, en 1934, a sus propietarios por el gobierno que derrocó a Leguía. El 20 de julio de ese año reaparece el diario bajo la dirección de Beltrán. Es su primer ensayo periodístico. El editorial de ese día plantea las mismas ideas, los mismos ideales y las mismas condiciones de libertad que Beltrán deseaba para que la sociedad peruana pueda desarrollarse con libertad y equidad: «Que todas las voces sean escuchadas», el deseo de una sociedad multiclasista «sin prejuicios de clase, sin exclusivismo de círculos» $\mathrm{y}$ "condenamos tanto el conservadorismo como la agitación revolucionaria, que es anarquía y esterilidad».

"Anarquía» y «esterilidad» son los dos extremos que un político con visión de estadista rechaza y combate; ellas representan el cáncer de cualquier sociedad organizada que busca los caminos del desarrollo y la justicia. Fanático del trabajo implacable y continuo, Beltrán se enferma gravemente y se ve obligado a dejar la dirección y organización del diario La Prensa, que había emprendido con tanto entusiasmo. Tendrían que transcurrir casi dos décadas para que reemprenda nuevamente el camino, asumiendo los mismos principios, las mismas ideas y las mismas premisas de libertad y estado de derecho para todos. Esto es prueba de coherencia y continuidad de un pensamiento mantenido a lo largo de toda una vida; prueba que no ocurre con frecuencia entre los políticos peruanos. Lo que sucede y se ha visto con malsana frecuencia es, por el contrario, el cambio continuo de camiseta, ideas y principios. Beltrán mantuvo una sola línea: la recta.

La Prensa segunda surgió en 1950 y constituyó el paradigma de lo que debe ser un diario moderno, objetivo y responsable. Dieciséis años después de su primer intento, Beltrán había recorrido prácticamente el mundo obteniendo información y estudiando cada detalle o cada modalidad del periodismo. Quienes lo acompañamos en esta segunda aventura periodística fuimos sorprendidos por los conocimientos que mostraba en cada aspecto involucrado en la organización, reporterismo, redacción, archivos, administración, publicidad, promoción, comercialización y estructura de una empresa periodística, maquinaria y hasta tipografía.

Fui el encargado inicial de elaborar los catálogos de tipos, de medición y uniformidad de titulares y bajadas. Me envió, por supuesto, a talleres, a lidiar con las componedoras y los procedimientos de lo que entonces se conocía como composición en caliente. Durante los siete años de ocupación del diario por el gobierno militar y sus allegados, los medios técnicos de composición habían variado sustancialmente. La socialización de los medios de comunicación estancó el proceso de modernización y mantuvo ese retraso tecnológico por casi una década. Beltrán ya no estaba como para ponernos al día.

Lo primero que hizo fue reclutar para esa nueva empresa a jóvenes universitarios, estudiantes de Derecho. Llegaría a confesar después que la profesión de abogado ofrecía 
una visión, más amplia que ninguna otra, de lo que ocurre en un país y en una sociedad, además de facilitarle al estudiante información y conceptos de lo que son los derechos y deberes de las personas. Su «enganchador» personal fue Carlos Rizo Patrón y el proceso de reclutamiento fue más complicado de lo que se podía suponer, debido más a nuestros prejuicios políticos que a los del propio Beltrán. ( $Y$ Y yo agrego: sin preocuparse de sus tendencias políticas ${ }^{27}$, que fue la reiteración de sus principios de siempre en cuanto al trato con las personas).

Lo cierto es que Beltrán protagonizó lo que en el Perú ya nadie puede discutir o poner en duda: una verdadera revolución periodística cuyos efectos se manifiestan hasta hoy. Eduardo Frei Montalva (padre), ex presidente de Chile y presidente de la Democracia Cristiana chilena, sostuvo públicamente en una reunión celebrada en Santiago: «La Prensa de Lima es el mejor diario de Latinoamérica».

En la lucha por la libertad de prensa Beltrán fue intransigente. Esto le valió no solo persecución y asedio domiciliario constantes, sino también prolongada prisión en el penal de máxima seguridad El Frontón. Fue necesaria la presión del organismo gremial americano, la Sociedad Interamericana de Prensa (SIP), y las protestas internacionales para que, tras un buen tiempo en esa isla, Beltrán pudiera salir libre.

Esa lucha por la libertad de prensa le valió también el despojo de sus acciones en las empresas periodísticas de su propiedad, la expropiación-confiscación del fundo agrícola Montalván y, lo que le fue más doloroso para él y su esposa, la destrucción de su casa del jirón Velaochaga, en San Marcelo, verdadera joya arquitectónica republicana con uno de los pocos balcones en esquina conservado con esmero. Existe la versión de que el general del Ejército Leonidas Rodríguez Figueroa, jefe de la División Blindada, se ofreció ante Velasco Alvarado para llevar sus tanques y demoler la casa de Beltrán.

\section{LA REVOLUCIÓN URBANA}

Beltrán, desde La Prensa, acometió otra revolución, esta vez a través de las campañas que, al margen de sus deberes informativos, el diario tenía el deber social de acometer y promover: el problema de la vivienda. El crecimiento de Lima desbordaba ya todo límite. El censo de 1963 había revelado que el promedio de personas por vivienda llegaba a 4,8, cifra cercana a las cinco personas, que revelan ya una rampante tugurización.

Beltrán emprende entonces una campaña que asimismo le valió la animadversión y el resentimiento. Los primeros en negar que existiera algún problema de vivienda fueron los diputados y ministros del régimen entonces imperante. $Y$ fueron después los propietarios de los arenales de Ancón, ante el planteamiento de Beltrán de urbanizarlos. Beltrán tuvo como centro de preocupación lo que entonces se conocía como «las barriadas». Fue in-

27 Cfr. Beltrán 1976. 
cansable para visitarlas cada sábado muy de mañana (como me consta) y también cuando viajaba al interior del país.

Con sistema y conocimientos, Beltrán desarrolló una metodología impactante para el diseño de las campañas de La Prensa y llegar, con ellas, a la solución del problema de la vivienda, rechazado reiteradamente por las autoridades políticas del régimen. Las campañas partían de los siguientes supuestos:

1) Dedicó sus planas durante varios meses a crear conciencia del problema cuando las autoridades nacionales (tal es el caso del presidente de la Comisión de Vivienda en el Parlamento) negaban con insistencia que existiera algo así como un problema de vivienda.

2) Dedicó asimismo sus planas y sus recursos (promoviendo incluso dos concursos arquitectónicos) a demostrar que los costos de construcción podían rebajarse notablemente mediante sistemas de construcción en serie. Convocó los concursos «La casa barata» y «La casa que crece», cuyos costos de construcción no llegaron a los veinte mil soles y quince mil soles. Los concursos fueron atacados duramente por el diario oficial La Nación más bien como «El negocio que crece».

3) De la misma manera, La Prensa desplegó campañas sobre el abaratamiento del terreno urbano. Esta campaña fue sin duda clarividente. La campaña insistió en la necesidad de vías urbanizadoras que rompieran las barreras económicas de las que estaba plagada Lima (barrios residenciales en el sur y sudoeste de Lima con servicios de infraestructura y vías troncales con financiamiento público). Sostuvo entonces Beltrán que podían aprovecharse los terrenos baldíos o inaprovechados alrededor de la ciudad, en un radio de quince kilómetros, desde la Plaza de Armas. La Prensa insistió en que:

Para que esta vasta superficie quede efectivamente al alcance de las posibilidades inmediatas y futuras de la expansión urbana, el Estado debe, en primer lugar, construir caminos urbanizadores que las comuniquen rápidamente con la ciudad y, en segundo lugar, adoptar las providencias necesarias para facilitar su urbanización a costos económicos que permitan la venta del terreno barato indispensable para la vivienda popular.

Muchos de los habitantes de esas nuevas zonas de Lima no saben que quien abogó y facilitó esas soluciones fue Beltrán, una persona considerada por sus antagonistas como «insensible y retrógrada».

4) El esquema de Beltrán consideraba finalmente el abaratamiento del dinero destinado a la construcción de viviendas populares. Y es nuevamente Beltrán quien se 
vuelca a encontrar la solución en las mutuales de crédito, fundando él mismo, con el personal de La Prensa, la primera mutual de crédito para la vivienda en el Perú. El sistema mutual se extendió notablemente hasta su deformación funcional y su extinción. Las cuentas abiertas en esa primera mutual de crédito para la vivienda pasaron de unas cuantas decenas hasta cientos de miles. Sus asociados pasaron también de unos cuantos a cientos de miles.

\section{LA REVOLUCIÓN CÍVICA}

Entre los objetivos primarios de su intervención en el periodismo estaba, al lado de la introducción en el Perú de la economía de mercado y la lucha contra la inflación, la restitución de las libertades del ciudadano peruano, amenazado siempre por la arbitrariedad de las autoridades y gobernantes. Objetivo fundamental era, por tanto, la instauración de un estado de derecho en el Perú. Las declaraciones de Beltrán, a su regreso al Perú, prestadas a la revista Caretas son, en este aspecto, clarificadoras.

La Prensa de Beltrán logró no solo el término de la dictadura de la década de 1950. Logró algo más, mucho más, que la salida de una de las tantas dictaduras militares habidas en el Perú. Como Beltrán le recuerda a Hildebrandt, fue La Prensa (de Beltrán, por supuesto) la que organizó y tramitó el documento de las ciento once firmas que hicieron posible no solo elecciones libres, sino también —y al mismo tiempo- la derogatoria de la represiva Ley de Seguridad Interior de la República, la reforma del Estatuto Electoral y la legalización de partidos políticos (como el APRA y el Partido Comunista Peruano) excluidos hasta entonces de toda participación electoral; en suma, fue La Prensa (para no decir el propio Beltrán) la que organizó y canalizó el inicio del estado de derecho en el país. Los tres puntos de esa declaración establecen textualmente que se luchará:

a) «Por la derogatoria de la Ley de Seguridad Interior y de toda otra disposición que recorte, vulnere o menoscabe el ejercicio de los derechos ciudadanos»;

b) «Por la sustitución del Estatuto Electoral en vigencia, que es un instrumento calculado para facilitar elecciones 'dirigidas' por otro que garantice la plena libertad en el proceso electoral y la absoluta limpieza de los escrutinios»; y

c) «Por la amnistía política general».

$\mathrm{Si}$ a estos resultados se agregan las campañas (innumerables) desarrolladas por los diarios que Beltrán organizó y llevó adelante, se sacará una idea bastante alejada de la caricatura con que siempre se quiso presentar de él y sus diarios. 


\section{LA REVOLUCIÓN DE LA ECONOMÍA}

A mediados de julio de 1959, Beltrán fue llamado por el presidente Prado para proponerle el cargo de primer ministro y ministro de Hacienda. La economía nacional atravesaba por uno de sus más difíciles momentos. El vicepresidente Carlos Moreyra Paz Soldán, íntimo amigo de Beltrán, le había adelantado la intención de Prado de llamarlo para proponerle esos cargos.

Beltrán era hombre que meditaba y programaba sus compromisos futuros con mucha anticipación y detalle. Lo hizo, en este caso, convocando a cinco de sus jóvenes periodistas (entre los que me contaba) para hacernos partícipes de la novedad y analizar la situación en la perspectiva del diario y del país. Todos opinamos por la aceptación, con cargo a la concesión de ciertas facultades especiales para superar la difícil coyuntura nacional.

Tras su nombramiento, tuve la suerte de que me asignara a su despacho para ver lo referente a correspondencia, textos, cables y telegramas. Pude así conocer los pormenores de una gestión ministerial ciertamente revolucionaria. Adicionalmente, acompañé a Beltrán en los viajes que, como ministro, emprendió a provincias. Fui testigo, por eso, de los ataques y violencia desatada contra él en Ayacucho y Cusco, principalmente, y el coraje con que supo enfrentarlos.

Beltrán encontró una economía en crisis. Tras su gestión, dejó una economía en pleno desarrollo. Algunos indicadores pueden ilustrar la eficiencia de la gestión de Beltrán en el ministerio, de 1960 a 1962 :

- El producto bruto interno (PBI) real creció a una tasa promedio anual de 9,1\% (Cuánto S. A.).

- El PBI per cápita se elevó 15\% en términos reales (Memoria del Banco Central de Reserva [BCR] de 1992).

- El consumo final por persona de 1962 aumentó 4,1 veces respecto al nivel precedente (Cuánto S. A.).

- El ahorro aumentó en casi 50\% respecto a 1959.

- La inversión hizo lo mismo en $60 \%$ (Cuánto S. A.).

- El costo real de la moneda estadounidense bajó de 31 a 27 soles de la época (Centro de Investigación de la Universidad del Pacífico [CIUP]/Consorcio de Investigación Económica [CIE], 1992).

- Las remuneraciones reales se elevaron 13\% (Instituto Nacional de Estadística e Informática [INEI]/Instituto de Estudios Económicos y Sociales [IEES]). 
- El consumo de calorías y proteínas de 1961 a 1963 llegó a 2.230 y 62 gramos, respectivamente; bajó después (1985) a 1.781 y 41,6, respectivamente (Cuánto S. A.).

- Las reservas netas internacionales llegaron a 128,5 millones de dólares (1959) y a 223,3 millones (1962) (Centro de Investigación de la Universidad del Pacífico [CIUP]/Consorcio de Investigación Económica [CIE], 1992).

- Las exportaciones pasaron de 322,6 millones de dólares (1960) a 556 millones (1962).

- La inflación pasó de 11,44\% en 1959 a 2,40\% en 1960 (Centro de Investigación de la Universidad del Pacífico [CIUP]/Consorcio de Investigación Económica [CIE], 1992).

- La devaluación pasó de una tasa anual de $18,12 \%$ a una de $-1,23 \%$.

- Por otro lado, la estructura del gasto público de 1959 a 1960 fue la siguiente:

\begin{tabular}{lcc} 
& $\mathbf{1 9 5 9}$ & $\mathbf{1 9 6 0}$ \\
\hline Sectores sociales & $30 \%$ & $35,9 \%$ \\
Defensa & $\mathbf{4 0 , 2 \%}$ & $37,0 \%$ \\
Administración pública & $19,9 \%$ & $17,6 \%$ \\
Promoción económica & $6,95 \%$ & $9,5 \%$
\end{tabular}

Se aprecia con claridad qué tan social fue la distribución de los recursos durante el periodo que correspondió a Beltrán: 5,9\% de aumento a los sectores sociales, baja notoria en los gastos de defensa y armamentos, disminución de recursos a la administración pública desburocratizada y aumento en los recursos que correspondían al crecimiento económico.

De haber continuado esa tendencia en la distribución del gasto público, podríamos haber llegado a una ley de presupuesto funcional con detracción de recursos en los sectores menos productivos y aumento en los que se destinan al capital social y al crecimiento económico. El Perú pudo exhibir los mejores indicadores de salud de la región (según la Oficina Panamericana de Salud).

Si se tiene en cuenta, además, que durante la gestión de Beltrán se logró, por primera vez en años, la histórica meta de haber eliminado el déficit fiscal y logrado, después, el primer superávit; puede uno de verdad sentir auténtica nostalgia de Pedro G. Beltrán. 


\section{Bibliografía}

BELTRÁN, Pedro G. (1976). Instrucciones autógrafas sobre su libro La verdadera realidad peruana. Madrid: Editorial San Martín.

HILDEBRANDT, César (1978). Entrevista. En: revista Caretas, nro. 538, 6 de abril.

ORTEGA Y GASSET, José (1963). «Vieja y nueva política». En: Revista de Occidente. Madrid.

SOCIEDAD NACIONAL AGRARIA (1928). "Planos y perspectiva». En: Memorias de la Sociedad Nacional Agraria. 



\section{José Carlos Mariátegui \\ (1894-1930) \\ IVÁN Alonso}



Mariátegui es el pensador más influyente de la izquierda marxista peruana. Socialistas y comunistas, desde los más moderados hasta los más radicales, se han reclamado seguidores de sus huellas. Las preocupaciones que inspiran su pensamiento han tenido una continuidad histórica y, modificadas quizá en sus manifestaciones exteriores, pero en lo esencial inalteradas, se mantienen vigentes. Su influencia seguramente trascenderá el siglo XX.

$\mathrm{El}$ «problema del indio» es el centro de las preocupaciones de Mariátegui en sus 7 ensayos de interpretación de la realidad peruana, su obra capital y la única de la que nos ocuparemos aquí ${ }^{28}$. El problema del indio es el problema del Perú, de los peruanos. Hay una escisión geográfica y racial, entre costa y sierra, entre criollos e indios, pero que es importante solamente porque tiene un trasfondo vital que tiende a perpetuarse. Lo que convierte al indio en un problema es «el conflicto y el contraste entre su predominio demográfico y su servidumbre —no sólo social y económica ${ }^{29}$. El régimen social y económico condena al indio a la miseria moral y material. Se ha perdido el bienestar material del que disfrutaba el pueblo incaico. El problema hunde sus raíces en la conquista española, que instaura una economía feudal, y se ramifica en diversos aspectos de la vida política, social y cultural, sobreviviendo a la Independencia como una pesada «herencia colonial».

El problema del indio "palpita dolorosamente» en cada uno de los 7 ensayos. Citando al poeta José Gálvez, dice Mariátegui: «por vago que fuese el legado psíquico que hayamos recibido de los indios, siempre tenemos algo de aquella raza vencida, que en viviente ruina anda preterida y maltratada en nuestras serranías, constituyendo un grave problema social, que si palpita dolorosamente en nuestra vida, ¿por qué no puede tener un lugar en nuestra literatura $[\ldots]]_{n^{30}}$. Es significativo que escoja ilustrar de esta manera su tesis indigenista en «El proceso de la literatura». Mariátegui se niega a trazar una línea divisoria entre sus concepciones estéticas y sus concepciones morales y políticas. «La literatura de

28 Existen diversas ediciones de los 7 ensayos de interpretación de la realidad peruana, algunas de ellas muy descuidadas, lamentablemente. Una muy recomendable es la tercera edición corregida de la Biblioteca Ayacucho (Caracas, 2007), prologada por Aníbal Quijano y con notas, cronología y bibliografía preparadas por Elizabeth Garrels. Todas nuestras citas están referidas a esta edición.

29 Cfr. Mariátegui 2007 [1928]: 281.

30 Cfr. Mariátegui 2007 [1928]: 234. 
un pueblo» — dice en otro pasaje de ese mismo ensayo— «se alimenta y se apoya en su substractum económico y político» ${ }^{31}$.

Los 7 ensayos son otros tantos ejercicios de aplicación del materialismo histórico. Tienen una intención analítica, interpretativa, pero también tienen la finalidad de sustentar un programa político, el programa de la revolución socialista. El materialismo histórico es la doctrina marxista según la cual las condiciones económicas, es decir, las formas como se organizan las actividades productivas y se relaciona la gente en el proceso de producción, determinan todos los fenómenos sociales, políticos e intelectuales. En consecuencia, la única manera de cambiar esos fenómenos es transformando las condiciones económicas. En el ensayo sobre «El proceso de la educación», por ejemplo, dice Mariátegui: «El problema de la enseñanza no puede ser bien comprendido en nuestro tiempo, si no es considerado [como] un problema económico y como un problema social $\aleph^{32}$; y más adelante: «El problema del analfabetismo del indio resulta ser, en fin, un problema mucho mayor, que desborda del restringido marco de un plan meramente pedagógico [...]. La escuela elemental no redime moral y socialmente al indio. El primer paso real hacia su redención, tiene que ser el de abolir su servidumbre» ${ }^{33}$. La misma doctrina se expresa en «El factor religioso»: «El socialismo, conforme a las conclusiones del materialismo histórico [...], considera a las formas eclesiásticas y doctrinas religiosas, peculiares e inherentes al régimen económico-social que las sostiene y produce. Y se preocupa, por tanto, de cambiar éste y no aquéllas»" ${ }^{34}$. Y en una auténtica profesión de fe concluye que «los actuales mitos revolucionarios o sociales pueden ocupar la conciencia profunda de los hombres con la misma plenitud que los antiguos mitos religiosos» ${ }^{35}$.

El ensayo titulado "Esquema de la evolución económica» traza la interpretación mariateguista de la historia del Perú con la pluma del materialismo histórico. El hecho primordial es la destrucción de la «formidable máquina de producción» incaica y la instauración de una economía feudal durante el Virreinato. La enormidad del territorio conquistado por los españoles y la escasez de brazos que encontraron dieron lugar al latifundio y la servidumbre. La importación de esclavos para trabajar en las haciendas de la costa introdujo en la naciente sociedad feudal «elementos y características de una sociedad esclavista ${ }^{36}$. Con la Independencia se inicia una segunda etapa en la historia económica del Perú. Pero la Independencia no es la causa, sino más bien la consecuen-

31 Cfr. Mariátegui 2007 [1928]: 201.

32 Cfr. Mariátegui 2007 [1928]: 129.

33 Cfr. Mariátegui 2007 [1928]: 133.

34 Cfr. Mariátegui 2007 [1928]: 159.

35 Cfr. Mariátegui 2007 [1928]: 160.

36 Cfr. Mariátegui 2007 [1928]: 9. 
cia, sostiene Mariátegui, de los cambios económicos que estaban ocurriendo en el Perú. Una incipiente burguesía, cuyos intereses económicos estaban vinculados al comercio exterior, se enfrentaba a las restricciones impuestas por la Corona española, que reservaba a la metrópoli el derecho a comerciar con otras naciones. Fueron los intereses económicos de una clase emergente los que, sumados al movimiento intelectual independentista, determinaron su victoria, que no fue solamente la victoria de esa clase, sino también la de los capitales que dominaban el comercio internacional en ese momento particular de la historia del mundo occidental. El auge de la exportación del guano y del salitre «colocó nuestra economía bajo el control del capital británico» ${ }^{37}$, el mismo al que, tras la crisis fiscal originada por la deuda contraída precisamente con la garantía de los impuestos generados por esas exportaciones, se le entregó la administración de los ferrocarriles. Las utilidades del guano y del salitre, por otra parte, crearon «los primeros elementos sólidos de capital comercial y bancario» nacional ${ }^{38}$, lo que habría sido el comienzo de una saludable transformación de lo que hasta entonces era una sociedad aristocrática y feudal, si no hubiera sido porque fortalecieron el poder de la costa y «acentuaron el dualismo y el conflicto que hasta ahora constituyen nuestro mayor problema histórico» ${ }^{39}$.

Esta síntesis interpretativa de nuestra historia económica contiene las semillas de un programa político. Al momento de escribir Mariátegui los 7 ensayos, la economía peruana sigue siendo fundamentalmente una economía agraria. Es esa economía agraria la que sostiene, en la sierra, como «sucesor de la feudalidad colonial», dice Mariátegui en «El problema del indio», el gamonalismo, entendido como un fenómeno político en el que una «jerarquía de funcionarios, intermediarios, agentes, parásitos, etcétera» se pone al servicio del poder económico del latifundio para mantener un régimen de explotación del indígen $\mathrm{a}^{40}$. La agricultura de la costa, por otra parte, en la que prevalecen los cultivos de algodón y caña de azúcar, responde principalmente a los intereses del capital extranjero, que «se opone [...] a que se organice y desarrolle de acuerdo con las necesidades específicas de la economía nacional $»^{41}$. A los mismos intereses responden la minería, el comercio, el transporte y la industria moderna. La redención del indígena y de la clase trabajadora sólo es posible poniendo fin a la explotación mediante un cambio en la propiedad de la tierra y de los demás medios de producción. Mariátegui reclama, por un lado, «una política dirigida $[. .$.$] a una distribución menos desigual e injusta de la tierra { }^{42}$, es decir, la redis-

37 Cfr. Mariátegui 2007 [1928]: 14.

38 Cfr. Mariátegui 2007 [1928]: 14.

39 Cfr. Mariátegui 2007 [1928]: 15.

40 Cfr. Mariátegui 2007 [1928]: nota al pie de la p. 26.

41 Cfr. Mariátegui 2007 [1928]: 83.

42 Cfr. Mariátegui 2007 [1928]: 59. 
tribución de la tierra, la cual «en ninguna parte [...] ha sido posible sin leyes especiales de expropiación que han transferido el suelo a la clase que lo trabaja» (ibídem); y por otro, con las haciendas azucareras y algodoneras de la costa en mente, «una política social de nacionalización de las grandes fuentes de riqueza» ${ }^{43}$.

Este programa político fue llevado a cabo cuarenta años después por el gobierno militar que tomó el poder en 1968 y que hizo de la lucha contra la «oligarquía» y el «imperialismo» sus principales banderas políticas. El gobierno militar decretó una reforma agraria que disolvió los latifundios; distribuyó tierras a las cooperativas y comunidades; nacionalizó minas, pozos petroleros e industrias; y creó la comunidad industrial, que con el tiempo serviría para que los trabajadores se convirtieran en propietarios de las empresas y participaran en su dirección. La llamada Revolución peruana fue el mayor intento de transformación de la estructura económica del país; y fue también, defensiblemente, el mayor fracaso. En las décadas siguientes, la agricultura y la industria languidecieron por falta de inversión. Los cambios, reales o potenciales, en la propiedad de la tierra y otras fuentes de riqueza llevaron, a la larga, a un estancamiento de la productividad que perjudicó a los campesinos y a los trabajadores más que a nadie.

¿Cabía esperar otra cosa? Si bien Mariátegui no es responsable del fracaso económico de la Revolución peruana, su influencia en la ideología y el programa político de esta es innegable. No hay por qué suponer que Mariátegui habría suscrito el ideario del gobierno militar ni las reformas que aplicó en todos sus detalles, pero las consecuencias de esas reformas pueden echar luz sobre la validez de la interpretación de la historia económica en la que se basaban. A pesar de las pretensiones del marxismo, el análisis mariateguista de las condiciones económicas no puede realmente llamarse científico. Son cuestionables la consistencia doctrinaria de su visión del indio, el postulado de un socialismo incaico y su apreciación del latifundio como fenómeno económico.

Mariátegui quiere redimir al indio moral y materialmente, y para redimirlo no hay otra manera que devolverle la tierra. Del indio dice Mariátegui que «ha desposado la tierra", que "puede ser indiferente a todo, menos a la posesión de la tierra» y que la tierra "ha sido siempre toda la alegría del indio»". Se suspende aquí el materialismo histórico. La relación del indio con la tierra parece ser el único fenómeno social en este mundo que no está determinado por las condiciones materiales de la existencia. En la perspectiva del materialismo histórico, la relación del indio con la tierra, tal como la concibe Mariátegui, pertenece, para bien o para mal, a una etapa superada, pertenece a las condiciones económicas del pasado. Esa visión de la relación del indio con la tierra, sin embargo, condiciona la propuesta política de Mariátegui. No cabe, en su opinión, otra alternativa

43 Cfr. Mariátegui 2007 [1928]: 83.

44 Cfr. Mariátegui 2007 [1928]: 36. 
que la expropiación para devolverle al indio la propiedad de la tierra.

Evidentemente, lo que Mariátegui añora es el socialismo incaico. Como dice en su "Esquema de la evolución económica», el hecho primordial en la historia económica colonial es la superposición de una economía feudal «sobre las ruinas y residuos de una economía socialista ${ }^{45}$. Pero ¿qué es exactamente lo que se destruyó? Se ha discutido si el Imperio incaico era o no era socialista. Mariátegui recurre a la «suma ponderación» del historiador César Ugarte para caracterizar lo que llama la «economía socialista» o el "comunismo agrario» de los incas ${ }^{46}$ : «Propiedad colectiva de la tierra cultivable por el ayllu» — condición necesaria de una economía socialista—, "aunque dividida en lotes individuales intransferibles» — necesaria, pero no suficiente_—; "propiedad colectiva de las aguas, tierras de pasto y bosques por la marca o tribu, o sea la federación de ayllus establecidos alrededor de una misma aldea» — lo que también es compatible con una economía de propiedad privada, si los costos de establecer derechos de propiedad sobre esos recursos son mayores que los beneficios_- ; y finalmente «apropiación individual de las cosechas y frutos» — difícilmente un rasgo distintivo de una economía socialista o comunista ${ }^{47}$ — Si la caracterización que hace Ugarte es correcta, una política de expropiación de latifundios para darle al indio no una propiedad individual de la tierra, sino una propiedad comunal, como la que propone Mariátegui, tendría pocas posibilidades de redimir al indio, al menos materialmente.

Mariátegui, por otra parte, tampoco demuestra que el latifundio sea una forma de organización económica inferior a la «comunidad». Un esfuerzo de consistencia doctrinal lo lleva a preguntarse si acaso el latifundio se justifica por una mayor productividad, independientemente de cómo se distribuya la producción. Su respuesta es decepcionante. «Salvo los casos de las haciendas de caña [...], los cultivos de los latifundios serranos, son generalmente los mismos de las comunidades. Y las cifras de la producción no difieren ${ }^{48}$. ¿En qué se basa tal afirmación? «La única estadística de producción de la sierra, la del trigo, sufraga esta conclusión» ${ }^{49}$. La inferencia es riesgosa. Una generalización a partir de la evidencia de los rendimientos de un solo cultivo y, además, en un solo año no podría tenerse como válida. Pero ni siquiera existe esa evidencia; lo que existe, más bien, es una clamorosa tergiversación de la evidencia. Dice Mariátegui, citando a Castro Pozo ${ }^{50}$, cuyos datos se refieren al año 1917-1918: "La cosecha resultó, término medio, en 450 y 580

45 Cfr. Mariátegui 2007 [1928]: 8.

46 Cfr. Ugarte 1926.

47 Cfr. Mariátegui 2007 [1928]: 43.

48 Cfr. Mariátegui 2007 [1928]: 69.

49 Cfr. Mariátegui 2007 [1928]: 69-70.

50 Cfr. Castro Pozo 1924. Castro Pozo fue uno de los fundadores, con Mariátegui, del Partido Socialista del Perú. 
kilos por cada hectárea para la propiedad comunal e individual, respectivamente» ${ }^{51}$. Esta diferencia de productividad de $30 \%$ a favor del latifundio es inmediatamente puesta en tela de juicio: «Si se tiene en cuenta que las mejores tierras de producción han pasado a poder de los terratenientes» — sigue citando Mariátegui, sin aportar datos que sustenten esta afirmación - «y que la ignorancia del comunero lo lleva de preferencia a ocultar los datos exactos relativos al monto de la cosecha, por temor de nuevos impuestos o exacciones de parte de las autoridades» —ocultamiento que también cabría esperar de los latifundistas - «se colegirá fácilmente que la diferencia en la producción por hectárea a favor del bien de la propiedad individual no es exacta y que razonablemente, se la debe dar por no existente» ${ }^{52}$. Unas líneas después, sin embargo, Mariátegui, que suscribe sin reservas la argumentación de Castro Pozo, acepta a ojo cerrado diferencias porcentualmente menores, del orden de $20 \%$ y aun de $10 \%$, entre los rendimientos de distintas cosechas en el latifundio y la pequeña propiedad en la Rusia feudal. «El latifundio de la sierra peruana resulta, pues» — concluye Mariátegui-, «por debajo del execrado latifundio de la Rusia zarista como factor de producción ${ }^{53}$.

No son, pues, los 7 ensayos un modelo de rigor científico. Hay que tener en cuenta, sin embargo, que la motivación de Mariátegui no es la de un académico, sino la de un revolucionario. Más aun que interpretar la realidad, le interesa transformarla. Necesita un ideal que inspire a sus seguidores. Un estudio reciente sostiene que, así como Marx, en las propias palabras de Mariátegui, era el «inventor del proletariado», al que había hecho tomar conciencia de su importancia como clase portadora del espíritu revolucionario, así también «Mariátegui, para construir el mito social peruano, inventará —al estilo de Marx - al indio que llamará socialista, encargado de la transformación y la revolución social en el Perúi ${ }^{54}$.

Pero el pensamiento de Mariátegui no deja de ser un pensamiento original (lo cual no quiere decir acertado). Introduce al Perú el método marxista, pero lo hace creativamente, reconociendo las significativas diferencias entre la realidad social y económica de la Europa occidental (sobre la cual Marx teorizó) y la realidad peruana. A diferencia de la sociedad europea occidental, la sociedad peruana no era una sociedad propiamente capitalista; en ella más bien convivían un comunismo indígena primigenio, una economía feudal y una incipiente industria moderna sujeta a los intereses del capital extranjero, dando lugar a un sistema de explotación más complejo. Quijano, en su prólogo a los 7

51 Cfr. Mariátegui 2007 [1928]: 70.

52 Cfr. Mariátegui 2007 [1928]: 70.

53 Cfr. Mariátegui 2007 [1928]: 70.

54 Cfr. Castro 2006: 110-111. 
ensayos $^{55}$, considera este el «hallazgo básico de la investigación mariateguiana» y agrega que «ese enfoque mariateguiano era el único que en toda América Latina podía, en ese momento, dar cuenta de la especificidad profunda, de la originalidad del proceso histórico de estas formaciones sociales dentro de su común pertenencia a la legalidad general del orden capitalista imperialista ${ }^{56}$. Esa particularidad de la sociedad peruana (y latinoamericana), en el contexto de una expansión monopólica del capitalismo internacional, tenía implicaciones muy diferentes que aquellas previstas por Marx para la sociedad europea. Mientras que en esta el capitalismo había liquidado el feudalismo, y debía, a su vez, ser liquidado por la revolución socialista, en el Perú el capitalismo (extranjero) era un aliado del feudalismo y era necesario liquidarlos a ambos simultáneamente.

De aquí parten la polémica y la eventual ruptura con Haya de la Torre. Tanto Haya como Mariátegui estaban por la nacionalización de tierras e industrias, contra el gamonalismo y el imperialismo y por la revolución proletaria y campesina. Pero Haya pensaba que, si bien el imperialismo era en Europa la última fase del capitalismo, en América Latina era la primera, porque era gracias al imperialismo que había llegado aquí la industria moderna. Había que nacionalizarla, pero antes había que dejarla desarrollarse, es decir, había que dejar que se desarrollara una burguesía o clase capitalista nacional, para liquidar primero el feudalismo; luego vendría la revolución socialista que liquidaría el capitalismo. Mariátegui discrepa completamente de Haya en este punto. La industria nacional era una industria de enclave, subordinada «a los intereses y a las necesidades de los mercados de Londres y de Nueva York», que veían en el Perú «un depósito de materias primas y una plaza para sus manufacturas ${ }^{57}$. En el Perú, el capitalismo no iba a liquidar el feudalismo porque ambos eran parte de un solo sistema de dominación.

La influencia de Mariátegui en el pensamiento político peruano ha sido grande, pero también variable con el tiempo. Cuenta Basadre que los 7 ensayos fueron recibidos con silencio, provocando en Mariátegui un profundo desencanto ${ }^{58}$. Su temprana muerte y, tras ella, la radicalización del Partido Socialista del Perú, que a los pocos meses se convirtió en el Partido Comunista Peruano, permitieron que Haya de la Torre se erigiera en la figura principal de la izquierda. El interés por el pensamiento de Mariátegui permanece confinado a los movimientos de la extrema izquierda, que se dividen y subdividen en torno a cuestiones de doctrina y estrategia. Dice Quijano que el pensamiento de Mariátegui «estuvo virtualmente enterrado durante casi treinta años, hasta que el nuevo desarrollo de las luchas de clases en el Perú y el mundo, y la crisis política de la dirección del movimiento

55 Cfr. Quijano 2007.

56 Cfr. Mariátegui 2007 [1928]: lxxix-lxxx.

57 Cfr. Mariátegui 2007 [1928]: 81.

58 Cfr. Basadre 1983: 28. 
comunista oficial» lo devolvieron al primer plano del debate ${ }^{59}$. Desde entonces, se han reclamado seguidores suyos, interpretándolo cada uno a su manera, la izquierda reformista, representada por personajes como el ex presidente Belaunde y el general Velasco; apristas y nacionalistas de distinto tipo; y comunistas estalinianos y maoístas, entre otros ${ }^{60}$.

Esa influencia tan grande y tan variada se explica porque el pensamiento de Mariátegui, más allá de sus aciertos y sus desaciertos, es una reflexión apasionada sobre problemas vitales del país, que han preocupado tanto a las generaciones que lo precedieron como a las que lo sucedieron. El problema del indio y la dominación ya está presente en los discursos de González Prada al final del siglo XIX. En las primeras décadas del siglo XX el problema se discute intensamente, si bien tratándoselo como un problema cultural. Mariátegui lo plantea como un problema de origen económico. En las décadas siguientes, la oligarquía y el imperialismo son, en el debate político peruano, la encarnación del dualismo económico que mantiene en la pobreza a la mayoría del país. Hoy no se habla ya de oligarquía, pero hay quienes sospechan que la globalización es la nueva forma del imperialismo; y aun entre quienes no se sienten seguidores de Mariátegui se advierte la preocupación por la persistente pobreza de una minoría, en medio de una bonanza económica, lo que parece ser un residuo de ese dualismo y que algunos llaman «exclusión» (concepto que, sin embargo, nos parece superfluo por razones que no es el caso mencionar acá).

La vida de Mariátegui también explica, en parte, su influencia. Abandonado por el padre y afectado por una dolencia en una de sus piernas, Mariátegui apenas completa la primaria y se hace autodidacta. A los catorce años comienza a trabajar en el diario $\mathrm{La}$ Prensa como ayudante, mensajero y corrector de pruebas. De allí pasa al periodismo, para luego, en sus propias palabras, elevarse del periodismo a la doctrina. Se inicia como cronista hípico y de páginas sociales; después se convierte en crítico literario, comentarista político y cronista parlamentario. Estrena una obra de teatro, y compone otra en colaboración con Valdelomar, que no llega a estrenarse. Publica artículos en Colónida, una revista literaria, y en Nueva Época, que además de literaria es una revista dedicada a la crítica social. Participa en la fundación de El Tiempo y La Razón, dos diarios de oposición al gobierno de Pardo. Desde La Razón apoya una huelga de trabajadores en mayo de 1919, en protesta por el encarecimiento del costo de vida, y toma parte en la organización de la Federación Obrera Regional Peruana. Al tomar Leguía el poder, en julio de 1919, La Razón comienza una campaña de oposición, a raíz de lo cual la imprenta del Arzobispado de Lima se niega a seguir imprimiéndolo. Más importante aun para la trayectoria de Mariátegui, el gobierno le ofrece la alternativa del exilio en Europa, con gastos pagados, o ir preso. Mariátegui opta por lo primero, y es en esos años, entre 1920 y 1923, que adopta

59 Cfr. Mariátegui 2007 [1928]: xlix.

60 Cfr. Mariátegui 2007 [1928]: li-lv. 
el marxismo y queda deslumbrado por la Revolución rusa, a la que considera el acontecimiento más importante del siglo XX ${ }^{61}$. De vuelta a Lima, dicta conferencias a obreros en la Universidad Popular González Prada, por invitación de Haya de la Torre, a quien sucede como director de la misma al ser deportado por Leguía. Poco tiempo después comienza a publicar en la revista Mundial algunos de los artículos que luego se convertirán en los 7 ensayos. En 1924 sufre la amputación de su pierna izquierda, a causa de un tumor maligno que lo pone al borde de la muerte; pero Mariátegui se recupera y vuelve a su actividad política e intelectual. En 1926 funda la revista Amauta, que da lugar al apelativo con el que se le conoce, la cual dirige hasta el final de su vida. La revista es clausurada por su apoyo al movimiento obrero y su oposición al gobierno de Leguía, que dice haber descubierto una conspiración comunista. Mariátegui es apresado y recluido por seis días en un hospital militar; Amauta reaparece seis meses después. En abril de 1930, Mariátegui muere prematuramente, a los 35 años de edad. La dedicación intelectual, el compromiso político, la lucha contra la adversidad de todo tipo hacen de Mariátegui «un héroe desde un sillón de impedido», en palabras de Basadre; «un mito, robustecido por el recuerdo de la muerte prematura, de la enfermedad heroicamente afrontada, de la continuidad terca en las ideas, del brillo a veces genial en el talento» ${ }^{62}$.

Hay un momento en la vida de Mariátegui en el que parece haber un punto de inflexión, un cambio radical en su perspectiva política. Al comienzo de su carrera periodística, como cronista hípico y social para revistas como El Turf, Mundo Limeño y Lulú, se codea con la «alta sociedad» limeña, buscándose, como dice Quijano, «un lugar en el establishment social y cultural ${ }^{63}$. Poco a poco viene el desencanto con la frivolidad de ese mundo, con su complacencia y su desdén por lo que empezaba él a percibir como los grandes problemas nacionales. A partir de 1917 se dedica casi exclusivamente al periodismo político. Los 7 ensayos están llenos de ironía sobre ese mundo que ha dejado atrás. Dice en un pasaje de «El proceso de la literatura», que trata sobre la figura literaria de Ricardo Palma y el retrato que este pinta de la sociedad limeña: «El demos criollo o, mejor, limeño, carecía de consistencia y de originalidad. De rato en rato lo sacudía la clarinada retórica de algún caudillo incipiente. Mas, pasado el espasmo, caía de nuevo en su muelle somnolencia ${ }^{64}$. Ochenta años han pasado, y esta observación no ha envejecido un segundo.

\section{BibLIOGRAFÍA}

BASADRE, Jorge (1983). Historia de la República del Perú, 1822-1933, sétima edición, corregida

61 Cfr. Basadre 1983: 14.

62 Cfr. Basadre 1983: 30-32.

63 Cfr. Mariátegui 2007 [1928]: xxxv.

64 Cfr. Mariátegui 2007 [1928]: 208. 
y aumentada, tomo X. Lima: Editorial Universitaria.

CASTRO, Augusto (2006). Filosofía y política en el Perú. Lima: Fondo Editorial de la Pontificia Universidad Católica del Perú.

CASTRO POZO, Hildebrando (1924). Nuestra comunidad indígena. Lima: Editorial El Lucero.

MARIÁTEGUI, José Carlos (2007 [1928]). 7 ensayos de interpretación de la realidad peruana. Caracas: Biblioteca Ayacucho.

UGARTE, César Antonio (1926). Bosquejo de la historia económica del Perú. Lima: Imp. Cabieses.

QUIJANO, Aníbal. «José Carlos Mariátegui: reencuentro y debate». En: Mariátegui, José Carlos (2007). 7 ensayos de interpretación de la realidad peruana. Caracas: Biblioteca Ayacucho.

Si hay un nombre sin el cual una mirada al devenir social, político y democrático del Perú del siglo XX sería incompleta, ese nombre es el de Víctor Raúl Haya de la Torre. Generación tras generación, el solo hecho de mencionarlo junto a la ideología y a la organiza- 


\section{Víctor Raúl Haya de la Torre \\ (1895-1979)}

Carlos Espá 

ción que él fundó el 7 de mayo de 1924, la Alianza Popular Revolucionaria Americana (APRA), provocaba agitación, quiebre en la conciencia de millones de peruanos, que no daba lugar a medias tintas ni a puntos de encuentro, pues la autodefinición era excluyente y, según el caso, plena de inusitado fervor o rencor. Aprismo y antiaprismo: más que una línea dibujada en la arena, tal incomprensión fue un abismo muchas veces tumultuoso, muchas veces sangriento, ahondado por el infortunio, las ideologías, los prejuicios, las tendencias mundiales, las diferencias de clase y, cómo no, la propaganda. Aprismo y antiaprismo, dos caras de una misma moneda que era el Perú, apartó a gobernantes y gobernados; provocó discordias entre intelectuales, odiosidades entre civiles y militares, desconfianza entre clericales y secularistas, limeños y norteños, ricos y pobres. Hubo miles de hombres y mujeres, compañeros y compañeras, que por simple vocación y entrega lo dejaron todo, lo dieron todo por Haya de la Torre. Marcharon a oscuras durante décadas. Padecieron persecución, desprecio, prisión y exilio. Sacrificaron sus mejores años. Cantaron himnos en medio de la nada. Enarbolaron pañuelos blancos de cara a las dictaduras. Postergaron profesiones. Abjuraron de la comodidad. Descuidaron a los suyos. Renunciaron a la individualidad y escogieron libre y entusiastamente transformarse en carnetizados engranajes de la maquinaria partidaria, la masa compacta y disciplinada que vino en bautizarse pueblo aprista. Algunos cedieron al fanatismo, cayeron en el sectarismo de «solo el APRA salvará al Perú». Otros despreciaron sus promesas, fueron disidentes, apóstatas, incurrieron inclusive en traición. Pero los más, los muchos, ofrecieron ante el altar partidario su presente, su futuro y hasta la vida en un instante. Lo hicieron por él, a quien las multitudes solían referirse, coreándolo militantemente, como «Compañero Jefe» o Víctor Raúl, y a quien en la intimidad sus más allegados llamaban Víctor o «El Viejo».

Fue Haya de la Torre el más importante líder que ha dado el Perú: extraordinario organizador, magistral orador, agitador y conspirador. Al decir de Andrés Townsend, fue más presidente que muchos presidentes y mandó más que muchos mandatarios. Intransigente, rebelde, beligerante y vehemente en la juventud, conciliador y magnánimo en la madurez, antes que socialdemócrata fue un luchador social por la democracia. Infatigable, audaz y memorioso, poseía singular carisma. Fue un hombre profundo, sensible, complejo y contradictorio; fue un noctámbulo, conversador hipnotizante, consumado 
táctico y estratega, refinado melómano, aficionado al teatro clásico y a la poesía castellana e inglesa. Fue humanista, pensador, filósofo, pero, sobre todo, fue un intelectual superior que puso inteligencia y voluntad al servicio de una causa de su propia creación, el Partido Aprista, al cual, a lo largo de su azarosa biografía, fuese desde la legalidad, el destierro, el asilo, la clandestinidad de Incahuasi o la cárcel, forjó como se forja el acero en el yunque para impulsar una ideología original y latinoamericanista. Sin llegar a ocupar la primera magistratura de la República, a la que tantas veces lo elevó el pueblo y la que tantas veces le fue arrebatada mediante el fraude o el veto, durante cincuenta años dominó la escena política peruana. Fue el gran catalizador de las facturas pendientes del Perú. Por fin, en 1978, electo presidente de la Asamblea Constituyente, no obstante desfalleciendo ya de muerte por la enfermedad y los años, el saludo que la guardia de honor le dispensó mientras transponía el Hall de los Pasos Perdidos, en el recinto parlamentario, sería el gesto mediante el cual la nación se reconciliaba, no con un hijo preclaro, sino consigo misma, extendiéndole de manera pródiga el reconocimiento que en su patria tanto le había sido retaceado, pero que durante décadas había recibido a manos llenas de líderes y pueblos del orbe.

Nació en Trujillo, capital de La Libertad, el 22 de febrero de 1895, en el seno de una distinguida familia que se remonta hasta los próceres de la independencia. Su padre fue Raúl Edmundo Haya y Cárdenas; su madre, Zoila Victoria de la Torre y Cárdenas. Aquel mismo año de 1895 don Raúl Edmundo fundaba el diario La Industria de Trujillo. Eran tiempos de convulsión social y política, de cataclismos nacionales y mundiales. En el Perú se vivía una guerra civil no declarada; los estertores de la guerra con Chile y la vergüenza de la subsecuente ocupación y el desmembramiento territorial. Como diría Luis Alberto Sánchez, en aquel entonces el elemento unificador de la patria era el odio que personificaba Manuel González Prada. Civilistas, pierolistas y caceristas pugnaban por el poder. Montoneras estallaban aquí y allá. Bastaba un piquete armado, un capitán avezado que marchara a Palacio de Gobierno a la cabeza de la soldadesca, para que estallase la revuelta. Víctima de una de aquellas algaradas, la de los hermanos Gutiérrez, moriría asesinado el presidente José Balta, quien antes se había levantado en Trujillo contra el gobierno de Mariano Ignacio Prado. Dos de los hermanos golpistas, a su turno, acabarían linchados por la turba enardecida, sus cadáveres colgados de un farol en la Plaza de Armas y, luego, de los campanarios de la Catedral de Lima, antes de ser finalmente devorados por las llamas en una gigantesca pira. El sucesor de Balta, Manuel Pardo y Lavalle, también caería asesinado cuando, en su condición de presidente del Senado, ingresaba al Congreso. Años más tarde, otro magnicidio, el del genocida Sánchez Cerro, rozaría de cerca la vida de Haya de la Torre. De un modo u otro, su familia nunca estuvo exenta de los ires y venires de la política, de esos súbitos avatares del destino, al extremo que, en 1904, con la victoria presidencial de José Pardo y Barreda, don Raúl Edmundo sería electo al Congreso por la 
bancada del general Andrés A. Cáceres.

Aunque la ciudad de Trujillo en la que Haya de la Torre transcurrió su niñez y adolescencia era todavía señorial y cultora de refinadas formas, el germen de la convulsión social ya había anidado en la región. Con la introducción del latifundio y el gran capital extranjero en las plantaciones cañeras de los circundantes valles de Chicama y Santa Catalina, aparecieron las primeras insurgencias sindicales que exigían la jornada laboral de ocho horas. Así también la economía de enclave, frente a cuya competencia los pequeños y medianos comerciantes trujillanos estaban irremediablemente perdidos, trasladaría del campo a la ciudad el malestar primero, la protesta después. Desde muy temprano, Haya de la Torre siguió con acuciosidad aquellos y otros desenvolvimientos: en la proximidad, junto a los trabajadores de la Liga de Obreros y Artesanos del Perú, con quienes se reunía en un local vecino a la casa paterna y gracias a cuyos contactos se familiarizó con el anarcosindicalismo y el inflamado discurso de Manuel González Prada; en la lejanía, respecto a la rebelión de Rumi Maqui en Puno y los levantamientos reivindicativos étnico-indigenistas de campesinos explotados por el gamonalismo, cual bestias de carga, mediante el alcohol y la coca, y que en el sur andino eran aplastados a fuego de metralla para encender aun más la animadversión al centralismo limeño.

Iniciado en las lides del periodismo en La Industria y estudiante de Letras en la Universidad de Trujillo, en 1914 el joven Haya de la Torre se incorpora al Grupo Norte, suerte de cofradía intelectual liberteña que animaba el filósofo Antenor Orrego y que integraba una generación de brillantes y ambiciosos jóvenes; entre ellos César Vallejo, Alcides Spelucín, Macedonio de la Torre, José Eulogio Garrido, Carlos Manuel Cox, Ciro Alegría e, inclusive, Enrique López Albújar. Es en la época del Grupo Norte cuando se registra el célebre brindis que César Vallejo dedica a Víctor Raúl: «Yo poeta alzo mi copa por este Pichón de Cóndor. Yo profeta anuncio que volará alto, muy alto, y será grande, grande, grande». Lo cierto es que 1914 habría de ser un año decisivo en la evolución política e ideológica de Haya de la Torre. En el Perú, el intento reformador y populista del presidente Guillermo Billingurst, quien infructuosamente había pretendido amansar a la República Aristocrática, era interrumpido de manera abrupta por el golpe de Estado del coronel Óscar R. Benavides. Fue un golpe cruento. El entonces ministro de Guerra, general Enrique Varela, héroe de la guerra del Pacífico, sería asesinado en Trujillo. Los índices acusadores apuntaron directamente al coronel Benavides. Nuevamente el sino de la dictadura y la impermeabilidad al cambio se imponía sobre los peruanos.

En el mundo, 1914 fue además el año trepidante en que se sucedieron, uno tras otro, acontecimientos que causaron profunda impresión en Haya de la Torre y que más tarde le inspiraron en la formulación del «Programa máximo» del APRA. El 28 de junio de 1914 era asesinado en Sarajevo el heredero al trono austriaco, el archiduque Francisco Fernando. Su muerte detonó la Primera Guerra Mundial. El polvorín de la región de 
los Balcanes y el contexto de una política de alianzas de las potencias europeas y de conflictos, «limpiezas étnicas» y odios irresueltos en Bulgaria, Grecia Montenegro, Serbia y Macedonia arrastró a Europa y luego a Estados Unidos a la hecatombe. Tal conflagración fue el prolegómeno de la caída del zarismo en Rusia y la aparición de nuevas formas de totalitarismo: comunismo, nazismo y fascismo. Por otro lado, en enero de aquel 1914, Sun Yat-sen, fundador del Kuomintang, y quien ya había sido presidente provisional de China, adquiría estatura mundial desde el exilio, al convertirse en la única alternativa republicana viable para el gigante asiático, tras la disolución del Parlamento y la fugaz restauración imperial de Yuan Shikai.

Pero fueron los sucesos de 1914 en América Latina los que marcaron más vívidamente la conciencia de Haya de la Torre. En medio de la convulsión de la Revolución mexicana, Estados Unidos interviene militarmente en la guerra civil y unidades de su Marina ocupan el puerto de Veracruz. Esa intervención precipitaría la caída del presidente Victoriano Huerta, el ascenso de Venustiano Carranza y la posterior aprobación de la Constitución de Querétaro, con su reforma agraria y nacionalización de tierras e industrias. Ello, sin embargo, no aplacó a las fuerzas de Pancho Villa y Emiliano Zapata. Años después, ambos líderes populares y agraristas acabarían vilmente asesinados.

También en 1914 el presidente Woodrow Wilson inauguraba el Canal de Panamá, estratégico y centenario proyecto que, mediante elaborado sistema de exclusas de más de ochenta kilómetros, unía dos océanos. Simbolizaba la conquista de la última frontera en el destino manifiesto de Estados Unidos por convertirse en la gran potencia del mundo y, de paso, imponer su hegemónico tutelaje sobre América Latina. Siendo el más portentoso trabajo de ingeniería jamás concebido, el canal constituía una herida abierta en el mapa del continente. Panamá, país inventado por Estados Unidos, arrancado a Colombia por la fuerza del garrote y las cañoneras del presidente Theodore Roosevelt, había cedido a los estadounidenses, por término indefinido y mediante el tratado Hay-Bunau-Varilla, todos los derechos, poder y autoridad sobre la zona del canal.

Es en este contexto nacional e internacional en el que deben interpretarse los arrestos de rebeldía auroral del fundador del aprismo. Muy pronto su vida se vería envuelta en la vorágine de los acontecimientos. En unos pocos años llegarían para él la presidencia de la Federación de Estudiantes del Perú; la jornada de las ocho horas, conquistada de la mano de los obreros anarcosindicalistas; su impulso a la reforma universitaria, inspirada en el Movimiento de Córdoba, junto a Luis Alberto Sánchez, Raúl Porras Barrenechea y Jorge Basadre; y la creación de las Universidades Populares Manuel González Prada, en las que colaboró José Carlos Mariátegui. Para 1922, a la edad de veintisiete años, a su retorno al país de su primera gira internacional que comprendió Bolivia, Argentina, Uruguay y Chile, Haya de la Torre era ya un político reconocido en el Perú y en la región. Había sido recibido por el presidente de Argentina, Hipólito Yrigoyen, y trabado amistad con líderes 
e intelectuales del nivel de José Ingenieros y Gabriela Mistral.

No es de extrañar, por tanto, que el presidente Augusto B. Leguía lo convocara a Palacio de Gobierno. Este episodio, que, a su turno, le fue confiado por el propio Víctor Raúl, es relatado por el presidente Alan García: «Durante la cena, Leguía lo condujo a lo que entonces sería el comedor, en el actual salón Túpac Amaru, y le dijo: 'Joven Haya, usted es muy inteligente, usted necesita mucha formación, quizá usted debería viajar por Europa'. Le hizo la propuesta de enviarlo cinco años a Europa como una especie de embajador. Se trataba de la oferta de un superhombre que era Leguía. Haya se fue pensando. Naturalmente lo alteró en su orgullo joven que le ofrecieran algo que lo ofendía, pero que a la vez era interesante. A la noche siguiente, en el Teatro Segura, vio una obra de Jacinto Benavente en la que un príncipe persigue a una pastora para adueñarse de ella. El príncipe llega hasta la choza donde vive la familia y todos se ponen de rodillas, pues lo confunden con un dios por la manera en que está vestido. Entonces el príncipe hace la reflexión: 'Si estos creen que soy un dios, tengo que comportarme como un dios'. En ese momento Haya pensó: 'Si Leguía cree que soy muy inteligente y que tengo gran futuro, debo portarme así'. Rechazó la oportunidad que lo hubiera parametrado y, entonces, al poco tiempo lo echaron del país» ${ }^{65}$.

En efecto, por encabezar la oposición a la consagración del Perú al Sagrado Corazón de Jesús, que el presidente Leguía pretendía como maniobra para una reelección constitucionalmente proscrita, Haya de la Torre es apresado en octubre de 1923 y directamente conducido a la isla-penal San Lorenzo. Se declara en huelga de hambre absoluta. La ciudadanía y el movimiento obrero protestan mediante paro general. El gobierno reacciona con violencia. Balas, bastonazos y sable de caballería son el lenguaje al que apela el régimen. Se dispone la clausura de las Universidades Populares. Estudiantes y obreros caen víctimas de la gendarmería. Es en este ambiente de convulsión social que el 7 de octubre de 1923 Leguía decide deportar a Haya de la Torre. Sería el primer destierro. A bordo del vapor Negada, parte rumbo a Panamá, punto inicial de un exilio que se prolongaría ocho años.

De Panamá, Haya de la Torre pasó a Cuba, entonces ocupada por Estados Unidos, merced a la Enmienda Platt, y de la isla enrumbó a México, país en el que es recibido por Gabriela Mistral y destacados intelectuales y artistas, incluidos los pintores Diego Rivera y José Orozco. Gobernaba México el general Álvaro Obregón. Su ministro de Educación, José Vasconcelos, acoge a Haya de la Torre y lo nombra su secretario.

Es en México que, el 7 de mayo de 1924, se registra la fundación del APRA. Haya de la Torre entrega al presidente de la Federación de Estudiantes la bandera de Indoamérica, la cual abarca, desde el sur del Río Grande, veinte naciones hasta el Cabo de Hornos. En

65 Cfr. García y Espá 2008: 120-121. 
su discurso, Haya de la Torre proclama: «Esta bandera flameará primero sobre las soñadoras muchedumbres de las juventudes que van abriendo el camino y más tarde serán los pueblos, comprendedores de los ideales bellos y justos, los que la agiten en el tumulto estremecido de sus luchas». Dos años después, en diciembre de 1926, Haya de la Torre publicaría bajo el título "What is the Apra?» en The Labour Monthly, órgano de difusión del Partido Laborista inglés, el artículo que es considerado el programa fundacional aprista. Contiene los cinco puntos del «Programa máximo»:

- Acción contra el imperialismo yanqui.

- Unidad política de América Latina.

- Nacionalización de tierras e industrias.

- Internacionalización del Canal de Panamá.

- Solidaridad con todos los pueblos y clases oprimidas del mundo.

Es importante resaltar que, tanto en el discurso fundacional como en el programa de cinco puntos, ya se advierte que la acción política en ciernes concebida por Haya de la Torre es explícitamente inclusiva y comprende a estudiantes, obreros, campesinos y clases medias. Ello, en oposición a la prédica del comunismo internacional, encarnado en el Komintern.

Entre la fundación del APRA y el artículo en The Labour Monthly, Haya de la Torre viaja a Europa y a la Unión Soviética, donde conoce a Leon Trotsky, Nikolái Bujarin, Gregory Zinoviev y Anatoly Lunacharski, jerarcas de la revolución, quienes aún no habían sufrido las implacables consecuencias de la razia estalinista. Comprueba in situ la grave ignorancia que acerca de América Latina campea en Moscú. Posteriormente, se matricula en The London School of Economics y Oxford. Serían años de activismo febril, organización de células apristas en Europa, la primera en París, y en América y, también, de metódico estudio, observación y reflexión, en los que perfiló un análisis crítico de las revoluciones mexicana y soviética. A la primera, pese a su heroísmo, la consideró intuitiva y desordenadamente reivindicativa. Respecto a la segunda, comprendió que se trataba de un proceso singular e intransferible a la realidad latinoamericana: «Sovietizar y rusificar el mundo, como lo vienen proclamando los propagandistas pueriles, es un romanticismo tan sincero como ingenuo».

A medida que el pensamiento aprista se decantaba, la colisión con el comunismo también se hacía inevitable. En febrero de 1927 tiene lugar el Primer Congreso Antiimperialista Mundial en Bruselas. Haya de la Torre protagoniza un encendido debate con Julio Antonio Mella, a la sazón convertido en agente comunista. Haya plantea la tesis del partido de frente único, no sometido a los dictados de Moscú ni a través de la Tercera 
Internacional o sus Ligas Antiimperialistas, y que incluyese tanto a obreros y campesinos como a la pequeña burguesía: «Un partido antiimperialista indoamericano no puede ser un partido de clase. Menos un partido de remedo o calco europeo y antidemocrático. Y, menos todavía, un partido sometido a dirección extranjera. Un partido antiimperialista indoamericano debe ser un partido nacional de frente único que agrupe a todas las clases sociales amenazadas por la explotación y que no suprima la libertad del hombre».

Tras el Congreso de Bruselas, queda claro que Haya de la Torre y el APRA no aceptarían «soluciones mágicas ni generalizaciones simplistas» trasladadas mecánicamente de Europa y Asia a América Latina. Tampoco aceptarían convertirse en comparsa o agentes de Moscú. La respuesta de los comunistas, a la que se aunaría Mariátegui, sería violenta y sectaria. El propio Julio Antonio Mella, quien antes de su conversión al comunismo había redactado un exaltado panegírico en homenaje a Haya de la Torre, trocó el elogio por el denuesto y publicó «¿Qué es el ARPA?», un panfleto plagado de desorbitadas invectivas que lo acusaba de «reformista» y «agente del imperialismo británico».

En su obra cumbre, El antiimperialismo y el APRA, culminada en México el 23 de mayo de 1928, Haya de la Torre responde a este y otros ataques del comunismo internacional. El libro demoraría siete años en salir a la luz, debido a la falta de medios y porque Haya de la Torre sufre un nuevo destierro en circunstancias en que se alistaba a trasladarse a Nicaragua para ponerse a órdenes de Augusto César Sandino. De cualquier modo, El antiimperialismo y el APRA constituye un claro y explícito deslinde con el comunismo: «El movimiento antiimperialista, que es y debe ser movimiento de frente único, demanda una organización política de frente único también. Las Ligas Antiimperialistas no bastan y el Partido Comunista sobra ${ }^{66}$. Desde 1927 Haya de la Torre había venido propugnando la tesis del partido de frente único según el modelo del Kuomintang chino: «El Kuomintang no fue fundado como partido de clase sino como un bloque o frente único de obreros, campesinos, clases medias, organizado bajo la forma y disciplina de partido, con programa y acción política concretos y propios. Sun Yat-sen, uno de los más ilustres espíritus creadores de nuestros tiempos, vio bien claro en su época que no era posible establecer en China un partido puramente de clase — socialista — o exclusivamente comunista más tarde. Lo admirable de la concepción política de Sun Yat-sen estuvo en su realismo genial» ${ }^{67}$.

Crítico y negador dialéctico del marxismo, Haya de la Torre señaló que la línea de divergencia entre el APRA y el comunismo había quedado fijada definitivamente en el Congreso de Bruselas de 1927. «El APRA plantea una total separación de los comunistas criollos, rendidos ante el sanctasanctórum de su fría ortodoxia, cuyo velo inmutable no se atreven a levantar. Quien está de rodillas no camina y, si lo intenta sin ponerse previamen-

66 Cfr. Haya de la Torre 1936: 59.

67 Cfr. Haya de la Torre 1936: 69. 
te de pie, tendrá que arrastrarse. Esto es lo que ha ocurrido en Indoamérica a los comunistas criollos. Los resultados de su posición de inmóviles repetidores del credo importado se comprueban en la estagnación del movimiento de la Tercera Internacional en nuestros países. Para tranquilidad y satisfacción del imperialismo y de la explotación feudal, los dogmas moscovitas carecen de significado y de contenido en nuestros pueblos ${ }^{68}$.

No es casual que el primero en acuñar el término «antiaprista» y autoproclamarse como tal fuera un comunista: Ricardo Martínez de la Torre. En 1933, publica el libelo Páginas antiapristas y acusa a Haya de la Torre de defender los intereses de la burguesía. No es casual tampoco que los comunistas se declarasen enemigos del APRA, pues el Estado antiimperialista era una alternativa popular y democrática que se interponía en sus afanes de instaurar la dictadura del proletariado. A sus críticas doctrinarias los comunistas agregaron descalificaciones altisonantes e infundios de toda laya en los que, paradójicamente, coincidieron con la oligarquía peruana y latinoamericana y los poderes fácticos empeñados en cerrar el paso al APRA. Comunistas y oligarcas compartirían durante décadas su odio irracional al aprismo y a Haya de la Torre. Para los comunistas, el APRA era la derecha. Para la derecha, el APRA era el comunismo. Ese odio compartido explica por qué, durante el siglo XX, los comunistas criollos se auparan cómplicemente a dictaduras de todo pelaje, embozadas y desembozadas, en su afán por destruir al APRA. Quien mejor personificó aquella malhadada asociación fue el agente comunista y mayordomo de la oligarquía Eudocio Ravines.

En agosto de 1930, el Oncenio, régimen de Leguía, llega abruptamente a su fin, con el levantamiento del comandante Luis Sánchez Cerro. El colapso del leguiismo no resultó de una insurrección popular. Fue más bien consecuencia de conspiraciones palaciegas y oligárquicas que, en el marco del natural desgaste por el prolongado ejercicio del mando, utilizaron el descontento social para desplazar a un antiguo adversario del civilismo. El éxito de dichas conjuras se debió al derrumbe del sistema financiero mundial tras el crack de Wall Street, el Viernes Negro de 1929. El pronunciamiento de Sánchez Cerro fue redactado por José Luis Bustamante y Rivero. Pronto el cuartelario caudillo fue objeto de los halagos de la oligarquía mercantilista. El viejo civilismo colmó de loas la mente y de escarapelas y chaflonería el pecho del comandante, a fin de convertirlo en su cancerbero; ciego puñal castrense, perro de presa de una casta. Un mes después de la caída de Leguía, la noche del 20 al 21 de setiembre de 1930, se funda el Partido Aprista Peruano.

Haya de la Torre recién retorna al Perú el 12 de julio de 1931. Ingresa a través de Talara. Es recibido triunfalmente en Trujillo, ciudad en la que se reencuentra con sus padres y hermanos después de nueve años de ausencia. Ya desde mayo de aquel año en

68 Cfr. Haya de la Torre 1936: 118. 
el Perú se entonaba la «Marsellesa aprista»: "Apristas, a luchar. Unidos a vencer. Fervor, acción, hasta triunfar nuestra revolución». Después vendrían «La marcha aprista» y «La marcha de los caídos». También en mayo de 1931 Manuel Seoane y Luis Alberto Sánchez habían fundado el diario La Tribuna. De manera que la presencia de Haya de la Torre era esperada por las muchedumbres tanto en las ciudades como en los villorrios y haciendas. Pueblo por pueblo, Haya de la Torre se dirige a Lima. Recorre Cajamarca, Chimbote, Recuay, Caraz, Supe, Barranca y Huacho. Llega a la capital el 15 de agosto. Preside un multitudinario mitin en la plaza San Martín. El 23 de agosto se dirige nuevamente al pueblo aprista, esta vez concentrado en la plaza de Acho. Expone «El programa mínimo» y «El plan de acción». Treinta mil personas acuden a escucharlo. Ante ellos, Haya de la Torre proclama la necesidad de equilibrar la economía nacional y el capital extranjero. Afirma que es posible «vivir en buena relación con el capital extranjero, haciendo de este un elemento cooperante para el desarrollo económico nacional ${ }^{69}$. Explica asimismo los fundamentos del Estado antiimperialista: democrático, científico, participativo y meritocrático. Define revolución como «evolución, renovación, sujeta siempre a los imperativos y limitaciones de la realidad $»^{70}$.

A Lima siguieron La Oroya, Cerro de Pasco, Tarma, Huancayo, Iquitos, Arequipa, Puno, Cusco, Tacna, Huánuco. El 11 de octubre de 1931, tras apenas tres meses de campaña, se desarrollan los comicios presidenciales. Lo que debió ser una arrolladora victoria aprista se convirtió en un burdo fraude, según consta en la Enciclopedia Británica. «El escrutinio empezó a marcar ventaja para Haya sobre Sánchez Cerro cuando ocurrió lo que se temía. Las ánforas que guardaba un Jurado Nacional de Elecciones comprometido con el civilismo fueron cambiadas y Sánchez Cerro tomó la delantera. No fue bastante y se anularon las elecciones de Cajamarca, entonces segundo electorado del país, donde el partido del pueblo había ganado en forma concluyente. Años más tarde, al hacerse obras de albañilería en el local ocupado en 1931 por el jurado, se encontró las ánforas cambiadas, cuyo contenido revelaba el triunfo de Víctor Raúl y los candidatos apristas» ${ }^{71}$.

Aquel fraude y el inmediato e instintivo impulso tiránico y represivo de un régimen con inclinaciones perversamente fascistas darían pie a un clima de confrontación social en la linde de la guerra civil. Haya de la Torre es encarcelado el 6 de mayo de 1932. Al día siguiente se amotina la tripulación de la marinería de los cruceros Grau y Bolognesi. Fue un acto de rebeldía juvenil que no provocó víctimas. Pero la sed de venganza exigía sangre. De inmediato y sin juicio de por medio, apenas un remedo de corte marcial, ocho marineros son fusilados en la isla San Lorenzo. Se colman las cárceles de presos políticos.

69 Cfr. Haya de la Torre 1977: 375.

70 Cfr. Haya de la Torre 1977: 97.

71 Cfr. Townsend 2004: 369. 
Como no caben ya en las gélidas San Lorenzo y El Frontón, tampoco en El Sexto, se inauguran campos de concentración en Satipo y Madre de Dios. Exactamente dos meses después, el 7 de julio de 1932, se produce la Revolución de Trujillo, levantamiento popular que se precipita con la toma del Cuartel O’Donovan y la captura de los jefes militares y policiales de la ciudad. La población civil es bombardeada por la Fuerza Aérea y, desde el puerto Salaverry, cañoneada por el crucero Grau. Con ello, Sánchez Cerro se convierte en infame precursor de Guernica. En medio del caos y la furia desbordada, un número de oficiales rehenes es victimado por la turba. En respuesta, la represión gubernamental se torna atroz y brutal. En aquel Año de la Barbarie se escribió una de las páginas más réprobas de nuestra historia: con infinita inmisericordia miles de peruanos y peruanas fueron asesinados en las trincheras o fusilados a mansalva en improvisados paredones en la Huaca de Mansiche, en las ruinas de Chan Chan. Aquel Año de la Barbarie sería también el inicio de un encono sáurico y longevo del grueso de las Fuerzas Armadas hacia el APRA. Al decir de Andrés Townsend: «En 1932 se diseñó la maniobra maestra de la oligarquía reaccionaria peruana con el fin de impedir el acceso del aprismo al poder. Incapaces de organizar un partido político que compitiera con el APRA decidieron convertir a las Fuerzas Armadas en una suerte de fuerza política sustitutoria penetrada de un antiaprismo visceral y ciego. La clase conservadora peruana no quiso o no pudo fundar un partido conservador o de derecha, pues fue orgánicamente incapaz de practicar la mínima disciplina que impone una militancia partidaria. La tendencia derechista peruana careció de partido y desde luego de ideología. En cambio, rodeó al Ejército, lo aduló sin recato y dejó a los hombres de uniforme mandar a su antojo, dentro de los límites del interés de su clase, siempre que la oligarquía y sus apoderados manejaran a su gusto la economía ${ }^{72}$.

A la Revolución de Trujillo sobrevendrían los alzamientos de Cajabamba, Huaraz y Cajamarca. El 18 de febrero de 1932 la representación congresal aprista, compuesta por veintitrés parlamentarios, había sido desaforada en pleno al amparo de la Ley de Emergencia. El APRA quedaba fuera de la ley. Su líder máximo permanecía encarcelado bajo severas condiciones de aislamiento en el Panóptico. En semejante trance, el régimen de Sánchez Cerro es objeto de repulsa internacional. El tirano recibe innumerables cartas de indignada protesta, provenientes de todos los confines del planeta. Las envían intelectuales como los Premio Nobel Romain Rolland, Gabriela Mistral, Bertrand Russell, George Bernard Shaw y personalidades de la talla de Mahatma Gandhi, George Lansbury, José Ortega y Gasset, Miguel de Unamuno, Gregorio Marañón, Luis Jiménez de Asúa, Alberto Lleras Camargo, Germán Arciniegas, Jorge Eliécer Gaitán. Exigen respeto a la vida y liberación inmediata para Haya de la Torre. Como botón de muestra está el cablegrama enviado por Albert Einstein: «Destrucción de ilustres personas es detrimento e

72 Cfr. Townsend 2004: 373. 
ignominia para colectividades nacionales y universales. Vosotros asumís la grave responsabilidad sobre la suerte de Haya de la Torre" ${ }^{73}$.

El 30 de abril de 1933 Sánchez Cerro muere asesinado por un fanático. Se declara el estado de sitio. En póstumo enroque de sátrapas, asume la presidencia el general Óscar R. Benavides, a quien el Congreso encarga completar el periodo de Sánchez Cerro. Al muerto y al sucesor los une su simpatía por el fascismo y sus impulsos tanáticos. Aun así, en agosto del mismo año, se decreta amnistía general. Haya de la Torre abandona la penitenciaría y miles de apristas recuperan la libertad y retornan del destierro. La primavera sería, no obstante, efímera. Duraría escaso año y medio. En noviembre de 1934 el aprismo es nuevamente proscrito, sus militantes encarcelados, sus dirigentes forzados al exilio. Es el inicio de la larga clandestinidad, según la describe Luis Alberto Sánchez: «Diez años, cinco meses, veintitrés días, entre noviembre de 1934 y mayo de 1945».

Para las elecciones presidenciales de 1936, Haya de la Torre, por tanto, se encontraba vetado. En aquellos comicios, el APRA endosó sus votos a la candidatura independiente de Luis Antonio Eguiguren Escudero, jurista y político honesto, ex alcalde y diputado por Lima, quien había renunciado a la presidencia del Congreso Constituyente en protesta por la espuria Ley de Emergencia de Sánchez Cerro. Eguiguren ganó limpiamente la elección, pero el general Benavides anuló el proceso. Alegó grotescamente: «El candidato Eguiguren no ha triunfado legalmente porque sus votos apristas provienen de un partido proscrito». Así, de un plumazo, Benavides permaneció tres años más en el poder, con una Constitución modificada a su medida mediante burdo plebiscito y un Congreso escuálido, groseramente domesticado y reducido a la tercera parte de sus miembros. En fraudulentos comicios de 1939, es electo presidente Manuel Prado, bautizado el «Stalin peruano», por su alianza con los comunistas. La derecha financiera y el comunismo criollo, mandadero de Moscú, se daban la mano contra Haya de la Torre. El APRA votó en blanco. Finalizado el recuento, resultó inocultable que el caudal aprista, el número de votos en blanco y viciados, era, pese al fraude, prácticamente equivalente a los obtenidos por Prado.

No sería hasta 1945 que el APRA recobraría sus derechos de ciudadanía. Para entonces, la Segunda Guerra Mundial había concluido, derrotados el fascismo y el nazismo. En la Unión Soviética, la siniestra dictadura de Josef Stalin eliminaba físicamente el más mínimo atisbo opositor. Era el capitalismo de Estado convertido en social imperialismo. Millones murieron asesinados. Un telón de acero, al decir de Winston Churchill, se cernía sobre Europa. Pero las «cuatro libertades» (política, económica, religiosa y de expresión), el New Deal y la política del buen vecino de Franklin Roosevelt ofrecían al mundo, en general, y a América Latina, en particular, la esperanza de una vida mejor. La cooperación democrática reemplazaba a la política del garrote y a la diplomacia de las cañoneras.

73 Cfr. Rodríguez 2006: 200. 
Atento observador de las tendencias internacionales, la evolución ideológica de Haya de la Torre, ya advertida en 1931, con la tesis del imperialismo ambivalente y la primera etapa del capitalismo, se había profundizado bajo el influjo de John Maynard Keynes, quien planteaba un intervencionismo estatal y políticas anticíclicas para impulsar el crecimiento económico. De 1935 es el esbozo de la tesis del espacio tiempo histórico. En 1941, Haya de la Torre publica el Plan para la afirmación de la democracia en las Américas. «Fue su respuesta a Roosevelt. Afirmó la necesidad de recoger y comprender el cambio extraordinario de la política norteamericana. Exigió que, al lograrse la victoria democrática en la guerra, se dieran dos pasos concretos para la buena vecindad. En primer lugar, crear el Banco de Exportación e Importación Interamericano. En segundo lugar, la constitución de una Unión Aduanera y Comercial de América Latina con Estados Unidos» ${ }^{74}$.

Así, el gran hito doctrinario de la larga clandestinidad es el interamericanismo democrático sin imperio, concepto incorporado como sexto punto del «Programa máximo» del APRA en el congreso clandestino del partido en 1942. Expresa el afán por «establecer relaciones más justas entre ambas Américas y afirmar la defensa mancomunada de la democracia frente al fascismo internacional». Es más, en 1948, Haya de la Torre declararía que la internacionalización del Canal del Panamá, punto cuatro del «Programa máximo», debía entenderse como interamericanización.

A este periodo corresponde asimismo la aproximación de Haya de la Torre a la Iglesia católica. Atrás quedaba el violento divorcio con la jerarquía eclesiástica registrado durante el leguiismo. Desde 1935, con el Primer Congreso Eucarístico Nacional, se había observado en el Perú un renacimiento del sentimiento y la fe religiosos que dio lugar a Acción Católica, organización que promovía una vida familiar, laboral y universitaria de contenido católico. Al mismo tiempo, el papado de Pío XII había impregnado a la Iglesia de un talante reformador y de apertura, incentivado la participación de laicos en la liturgia y flexibilizado la posición del Vaticano hacia la Iglesia ortodoxa y el movimiento ecuménico. En ese contexto Haya de la Torre abandona en 1942 la tesis de la separación entre Iglesia y Estado, y rechaza la necesidad de conflicto entre religión y ciencia.

El 20 de mayo de 1945, la plaza San Martín es el escenario para el «Discurso del reencuentro». Aquella es la más grande manifestación de la que se tenga memoria en la historia del Perú. Haya de la Torre proclama: «No se trata de quitar riqueza al que la tiene, sino de crear riqueza para el que no la tiene» ${ }^{75}$.

Sin embargo, el destino (o el azar, según Jorge Basadre) no siempre es propicio para que ideología y praxis vayan de la mano, particularmente cuando en ello participan cientos de miles de personas. «El Partido Aprista estaba en ascenso. Quizá si en el más

74 Cfr. García 2008: 62.

75 Cfr. Haya de la Torre 1977: 146. 
alto nivel de todos los tiempos» ${ }^{76}$. Esa colosal fuerza organizativa combinada con tantos años de privación, «de martirologio y catacumbas», como los llamó Haya de la Torre, condujo a la impaciencia y a la intolerancia a muchos apristas. En verdad, no era humanamente posible que una década de injusta proscripción, de tantas ofensas, no hubiese dejado huella en el alma de la militancia y de su dirigencia. A ello se agregó un agravio adicional. El alto precio que el APRA debía pagar por la recuperación de la legalidad para el partido y de la democracia en el Perú consistía en un nuevo veto a la candidatura de Haya de la Torre.

José Luis Bustamante y Rivero resulta entonces designado candidato del Frente Democrático Nacional, cuya columna vertebral es el Partido del Pueblo. Haya de la Torre participó entusiasta y personalmente en la campaña. Si en las tribunas el candidato era Bustamante y Rivero, quien en realidad presidía los mítines era Haya de la Torre. En pulquérrimos comicios del 10 de junio de 1945, Bustamante y Rivero obtiene arrasadora victoria sobre su único contendor, el mariscal Eloy Ureta, vencedor del conflicto con el Ecuador de 1941. La proporción de votos es dos a uno. Tan propicias circunstancias para el Perú, empero, naufragarían muy pronto en un mar encrespado por el sabotaje oligárquico, en complicidad con los comunistas, que dejó sin quórum al Senado, la impericia administrativa y la impaciencia política del aprismo, así como por la desubicación y personal inoperancia de Bustamante y Rivero, empeñado en ignorar por qué y por quién ocupaba la presidencia. De 1947 a 1948 Bustamante y Rivero legisla por decreto. En su tercer año de gobierno, inaugura un gabinete conformado por militares. El 3 de octubre de 1948 Bustamante y Rivero decreta la ilegalidad del aprismo y ordena la captura de sus líderes. El 27 de octubre de ese mismo año el clima de crispación política, escasez y acaparamiento de subsistencias es aprovechado por la plutocracia que financia al general Manuel A. Odría, ex ministro de Bustamante y Rivero, para dar el golpe de gracia a un régimen desahuciado a los tres años y tres meses de su instalación. La primera acción del gobierno de Odría es convalidar el decreto de Bustamante y Rivero que proscribe al APRA y arremeter contra sus líderes y militantes a quienes encarcela o deporta.

Haya de la Torre solicita asilo y se refugia en la embajada de Colombia el 3 de enero de 1949. Con la peregrina excusa de que al Estado perseguidor corresponde calificar el delito del que se acusa al perseguido, el régimen de Odría mantuvo a Haya de la Torre recluido en esa embajada durante más de cinco años. El caso llegaría a la Corte Internacional de Justicia de La Haya. El APRA sufrió con estoicismo el renovado vituperio oficialista, más persecución, destierro y cárcel. De allí la tan certera frase de Enrique Chirinos Soto: "Cada vez que Haya está libre, el Perú tiene democracia. Cada vez que está perseguido, refugiado o desterrado, el Perú padece una dictadura. Curioso paralelismo entre la vida a

76 Cfr. Chirinos Soto 1984: 95. 
salto de mata del fundador del APRA y los azares de la libertad en la tierra de los incas» ${ }^{77}$. Recién en abril de 1954 Haya de la Torre recobra la libertad. De su tiempo en el encierro es la obra Treinta años de aprismo.

El 28 de julio de 1956 el APRA retorna a la legalidad, con la llegada de Manuel Prado al poder. Se acentúa el grito «El APRA nunca muere!». Es el inicio de la Convivencia Democrática. Durante este periodo, «Haya quiere transmitir a los apristas su entusiasmo por los kibutz de Israel, la lucha por ganar espacio al mar de los Países Bajos, los sistemas cooperativos nórdicos, los experimentos de cogestión en Alemania Federal, las medidas de fomento industrial acelerado de Taiwán, la formación del Mercado Común Europeo. Para Haya, el programa y la política apristas debían estar a la altura de esta dinámica mundial $\aleph^{78}$. Para entonces, el Perú se encuentra ante el Haya estadista, el patriarca, el buscador de consensos, el magno demócrata. En 1961, a contracorriente de una moda que recorría América Latina, Haya de la Torre rechaza la Revolución cubana y advierte que Fidel Castro, al subordinarse a la Unión Soviética, impondría irremediablemente una dictadura. Ad portas de las elecciones de 1962, Haya de la Torre es blanco de inmisericordes ataques, para variar, provenientes por igual de la derecha y del comunismo. A pesar de cierta disidencia, de determinadas deserciones que dan lugar a un minúsculo grupo guerrillero, la respuesta de la militancia no se resquebrajó. Su lema: «A más calumnias, más aprismo».

El 10 de junio de 1962, por primera vez desde 1931, Haya de la Torre puede postular a la presidencia; son más de treinta años de itinerario marcado por la exclusión y la injusticia. Culminado el escrutinio, Haya de la Torre obtiene la victoria, pero, por escasísimo margen, no alcanza el tercio de los votos exigido por la Constitución. El Congreso es el llamado a elegir, pero las Fuerzas Armadas tienen planes distintos, ominosos y siniestros. Alegan «voluntad de fraude», vetan a Haya de la Torre y el 18 de julio de 1962 invaden el recinto parlamentario. El presidente Prado es depuesto. Es el retorno a «la normalidad» de Martín Adán. Se ha perpetrado un nuevo golpe de Estado antiaprista; igual de antiaprista al que sobrevendría el 3 de octubre de 1968 al mando del general Juan Velasco.

Tendrían que transcurrir dieciséis años para que, por fin, el Perú desagraviara a Haya de la Torre. En las elecciones para la Asamblea Constituyente del 18 de junio de 1978, el APRA obtiene más de 35\% de los votos; el mejor resultado electoral de su larga trayectoria. A los ochenta y tres años de edad, Haya de la Torre recibe más de un millón de votos. Fieles a su dúplice y añejo proceder, los comunistas pretenden formar un bloque antiaprista para impedirle acceder a la presidencia de la Asamblea. En enaltecedor gesto, que revela su sentido de la historia y del decoro, y que muestra su estatura política y personal,

77 Cfr. Chirinos Soto 1984: 164.

78 Cfr. Vallenas 2006: 245. 
Luis Bedoya Reyes desoye semejantes cantos de sirena. El 28 de julio de 1978 Haya de la Torre es ungido presidente de la Asamblea Constituyente por derecho propio y por la voluntad del pueblo. Recibe el saludo de la guardia militar de honor mientras se escuchan los acordes de la «Marcha de banderas». Es el final de una guerra civil no declarada pero latente. Luis Alberto Sánchez reflexiona: «Si uno examina el aporte castrense a la vida cívica nacional no puede ocultar una mueca de desencanto. No se trata de antimilitarismo doctrinario. No. Se trata de comprobar, sin lugar a dudas, los efectos de una educación malsana y antinacional. La nación reside y se apoya en el pueblo, no en el Estado, que, en este caso, traicionó a la nación y empobreció al pueblo» ${ }^{79}$.

En su discurso inaugural, Haya de la Torre exclamará emocionado: «Recuerdo y rindo homenaje a los héroes anónimos de la clandestinidad y la persecución. A los que resistieron, estoicos, largos años de cárcel y torturas. A los que padecieron la estrechez y la angustia del destierro. A los que mantuvieron, bajo tiranías y dictaduras, viva y alta la esperanza de un Perú libre, justo y culto». Un año después, el 12 de julio de 1979, firma la Constitución. Exánime por la salud quebrantada, el final se aproxima. El 2 de agosto de 1979 muere. Se apaga la vida, pero no se extingue el espíritu del gran luchador. La profecía del poeta se ha cumplido. En efecto, Haya de la Torre ha volado alto, muy alto, y su legado es grande. Gracias a él, en un país como el Perú, mestizo por sobre todas las cosas, los mestizos pueden expresarse en primera persona. El pueblo no es más objeto de estudio, sino sujeto de la acción política. El impacto del APRA es reminiscente al del movimiento por los derechos civiles en Estados Unidos. La figura de Haya de la Torre tiene la trascendencia de prócer y transformador del siglo XX. Aquello que Jorge Basadre llamó «la multitud, la ciudad y el campo» irrumpió en el Perú con Haya de la Torre, no de manera explosivamente efímera ni detrás de una revuelta o una montonera, sino con el sustento de una doctrina original y una organización independiente. Gracias a Haya de la Torre y a su perseverancia, se hizo visible en América Latina la inviabilidad histórica de un sistema antidemocrático y feudal; un sistema más que oligárquico, oligofrénico, cuyos representantes, plutócratas, rentistas, mercantilistas y gamonales, se fueron extinguiendo en el curso de los cincuenta años en que persiguieron al APRA. Pero, además, en un país de precaria institucionalidad, Haya de la Torre legó al Perú un partido político, probablemente el único que merezca el nombre de tal a lo largo de nuestra historia, el cual, a treinta años de su fallecimiento, vive y goza de buena salud. Jóvenes militantes apristas se unen a los viejos para conmemorar cada año el nacimiento de Haya de la Torre en el Día de la Fraternidad, así como, en el de su muerte, la multitud acongojada acompañó el cortejo fúnebre desde Lima hasta Trujillo. Conforme con su voluntad, el viejo líder fue enterrado en el cementerio de Miraflores. Rodeado de las banderas de las veinte naciones

79 Cfr. Sánchez 1981: 104. 
de su Indoamérica, descansan los restos de Víctor Raúl Haya de la Torre al pie de una enorme roca en la que sus seguidores inscribieron el más lacónico y hermoso epitafio: «Aquí yace la luz».

\section{Bibliografía}

CHIRINOS SOTO, Enrique (1984). La nueva Constitución y los partidos. Lima: Centro de Documentación Andina.

GARCÍA, Alan y ESPÁ, Carlos (2008). Perú visión. Lima: Gráfica Biblos.

GARCÍA, Alan (2008). La revolución constructiva del aprismo, teoría y práctica de la modernidad. Lima: sin editor.

HAYA DE LA TORRE, Víctor Raúl (1936). El antiimperialismo y el APRA, Santiago de Chile: Ercilla.

(1977). Obras completas, tomo V. Lima: Mejía Baca.

RODRÍGUEZ, Gregorio (2006). Víctor Raúl Haya de la Torre. Vida y obra. Lima: Instituto Víctor Raúl Haya de la Torre.

SÁNCHEZ, Luis Alberto (1981). Retrato de un país adolescente. Lima: Mosca Azul Editores.

TOWNSEND, Andrés (2004). Libertad e integración en América Latina. Lima: Fondo Editorial del Congreso del Perú.

VALLENAS, Hugo (2006). Haya de la Torre, politico de realidades. Lima: Instituto Víctor Raúl Haya de la Torre.

«Es importante para los pueblos del Perú fijar su origen y los cauces de su evolución. Contra lo que se ha afirmado hace poco en esta Cámara, [...] no podemos desvincularnos de la historia, ya que el recordar los tiempos pasados y hacer un alto en el camino es 


\section{Raúl Porras Barrenechea \\ (1897-1960) \\ Carlota Casalino Sen}



característico de los pueblos que han alcanzado un alto grado de civilización».

Raúl Porras Barrenechea. «Discurso en el Senado en homenaje al pueblo de Cañete en el cuarto centenario de su fundación». Lima, 31 de agosto de 1956.

\section{INTRODUCCIÓN}

En el Perú, durante la vida republicana, han destacado hombres y mujeres que realizaron actos que trascendieron a sí mismos y que contribuyeron a construir el país. Los hechos que realizaron son recordados por su generación y por las siguientes. Hubo algunos que concentraron diversos ámbitos en la participación de los asuntos públicos y en todos ellos sobresalieron con luz propia.

En el siglo XIX se trató de aquellos que fundaron la República y se comprometieron a través de actos cotidianos en la construcción de esta. En los momentos de crisis actuaron con responsabilidad y valentía, incluso ofrecieron su propia vida por el país. En el siglo XX, periodo de polarización y extremos, otros peruanos y peruanas mantuvieron la causa de la República y de su sociedad por encima de las presiones coyunturales, ya sean internas —intereses de grupos privados — o externas —intereses de otros países o de grupos económicos internacionales—. Raúl Porras Barrenechea (Pisco, 1897-Lima, 1960) forma parte del grupo de grandes peruanos del siglo XX que respondieron y estuvieron a la altura de lo que la historia les demandó en momentos cruciales.

Porras Barrenechea fue uno de los más importantes intelectuales del Perú del siglo XX y, como ciudadano consciente, no tuvo reparos en servir en la función pública durante gran parte de su vida. Su vida fue intensa y comprometida con el país. Conforme pasa el tiempo, se le recuerda mejor. Prueba de ello son la importancia en el mundo académico del Instituto Raúl Porras Barrenechea de la Universidad Nacional Mayor de San Marcos, las periódicas reediciones de su obra escrita y el parque Raúl Porras Barrenechea inaugurado el 26 de setiembre de 2008 en Miraflores con motivo de los 48 años de su fallecimiento.

Fue un intelectual —historiador, literato y abogado que destacó como maestro uni- 
versitario - vinculado al poder tanto del Legislativo como del Ejecutivo. En el último lustro de su vida, cuando el país salía del gobierno de Odría, aceptó ser representante en el Senado de la República y además fue parte del Poder Ejecutivo al ser canciller del presidente Prado. En el Parlamento, destacó por sus notables intervenciones en el Hemiciclo, llegó a ser vicepresidente y presidente del Senado. Cuando desempeñó la función de canciller participó con una posición conciliadora cuando la Organización de Estados Americanos, fuertemente presionada por Estados Unidos, comenzó a buscar el veto a Cuba.

En el ámbito de sus ideas políticas se autodefinía como un liberal. En la práctica política fue un republicano que cultivaba la virtud y actuó con responsabilidad frente a su país. En sus obras académicas era un romántico, al buscar de manera permanente las raíces de la peruanidad. Como liberal era un convencido del respeto a los principios de libre determinación de los pueblos y de la soberanía de cada país. Por su actitud de servicio en la función pública, su compromiso con la eficiencia y la excelencia, era un republicanista, porque anteponía los intereses públicos y de la nación a los privados.

Visto en perspectiva, se puede afirmar que su obra — tanto en la cátedra universitaria como en el Parlamento y la Cancillería — aportó en la construcción del Estado-nación. Si recordamos la definición de nación — propuesta por Benedict Anderson - en el sentido de ser una "comunidad política imaginada como inherentemente limitada y soberana», entonces podemos señalar que el aporte de Porras Barrenechea fue involucrarse de manera cotidiana en los asuntos limítrofes al definir con claridad la soberanía del país y sus hitos más complejos, los mismos que dieron una fisonomía más sólida del país frente al concierto internacional. En ese sentido, contribuyó directamente en la construcción y defensa de los límites del Perú.

Además, al dedicarse al pasado del Perú, contribuyó en dar profundidad a la comunidad política imaginada sustentada en este. Lo señalado no es un aporte menor, todo lo contrario. Como se sabe, los países del mundo contemporáneo tienen la tarea de construir sus respectivos Estados-nación y sus sociedades sobre bases modernas. Ello significa considerar los principios de la democracia representativa, el respeto a los otros, y la igualdad ante la ley como aspectos centrales. La base en la cual descansa el poder es el pueblo soberano, lo que significa una sociedad compuesta por ciudadanos activos, responsables, con derechos garantizados, libertades individuales y con identidad nacional. Si ello falla no se puede articular proyectos comunes como país, ni se puede participar en el concierto internacional en igualdad de condiciones y defendiendo los intereses del país. El aporte de Porras Barrenechea, al publicar sus investigaciones sobre la historia del Perú en procesos históricos tan importantes como la Conquista, la Independencia y la historia de los límites, fue trascendental, ya que contribuyó directamente en la construcción de eficaces ficciones orientadoras de la nación sustentadas en el pasado.

Por lo tanto, como intelectual vinculado al poder político, Porras Barrenechea forma 
parte del conjunto de pensadores y funcionarios que representan el patriotismo criollo del siglo XX. Esto último, según David Brading, significa —en el contexto del periodo republicano - tener una actitud firme y desarrollar un pensamiento vinculado a los intereses del país por encima de los intereses extranjeros, además de tener una actitud conciliadora ante las dificultades que presentaban los demás países de la región.

Los siguientes acápites pasarán revista a algunos aspectos en los cuales destacó Porras Barrenechea. En efecto, como intelectual, diplomático y representante en el Legislativo destacó por lo que dijo e hizo, por la manera como se desempeñó cotidianamente en sus responsabilidades públicas, por la entrega y amor al país expresados en cada acción.

\section{El inTELeCtUAL}

Se formó en la Universidad Nacional Mayor de San Marcos y destacó como alumno brillante. De 1912 a 1915 estudió en la Facultad de Letras, y de 1915 a 1920 en la Facultad de Derecho. En 1928 obtuvo el doctorado en Filosofía, Historia y Letras con una tesis sobre Felipe Pardo y Aliaga. No fue un intelectual aislado, sino que siempre buscó la compañía de sus compañeros de clases y, luego, de los estudiantes.

Participó en la Reforma Universitaria, un movimiento estudiantil y de profesores jóvenes que —bajo la influencia de la Reforma Universitaria de Córdoba de 1918plantearon que la universidad debía modernizarse, abrirse a la sociedad y dejar de estar restringida para la élite. Asimismo, formó parte del Conversatorio Universitario, que a su vez era la generación del Centenario. Ellos fueron jóvenes estudiantes, testigos de las celebraciones del centenario de la proclamación de la Independencia y de la batalla de Ayacucho. Algunos de ellos hicieron la ruta que los Ejércitos libertadores del sur y del norte habían transitado cien años antes. Esa experiencia les permitió conocer jóvenes de otros países de la región, abrir sus horizontes y revivir la importancia del americanismo y de la construcción de la República.

El grupo reunido en torno al Conversatorio Universitario pensó el Perú como problema. Fue el objeto de sus principales reflexiones y de sus investigaciones académicas más destacadas. Formaron parte del Conversatorio Raúl Porras Barrenechea, Jorge Basadre, Luis Alberto Sánchez, Jorge Guillermo Leguía, Manuel Abastos, Guillermo Luna Cartland, Ricardo Vegas García y Carlos Moreyra y Paz Soldán.

Porras Barrenechea es recordado por ser un gran conversador. Luis Alberto Sánchez cuenta que siempre estaba preocupado porque el tiempo no le alcanzaba para escribir todo lo que sabía y pensaba. Su casa — primero en la calle Mariquitas y después en la calle Colina - siempre fue un espacio de abierto debate y tertulia para sus colegas, alumnos, discípulos y amigos. Era polémico y le gustaba participar en la polémica y el intercambio de ideas. En eso era apasionado, dispuesto a enfrentarse a los demás, a 
defender sus ideas y principios, a ir contra la corriente.

Uno de sus principales objetos de pasión fue el Perú. Lohmann Villena señala que siempre mostraba un «indomable culto a la grandeza de la Patria, sentida con ardor, con pasión... Fue sobre todo un espíritu excepcional $»^{80}$.

Como parte de su trabajo intelectual, se desempeñó como periodista, crítico literario e historiador. Como periodista, tuvo un estilo festivo y burlón, producto de los artículos que escribió en la década de 1930. Se convirtió en el terror de políticos y hombres públicos, firmaba bajo el seudónimo «Don Dimas de la Tijereta». En calidad de crítico literario, estudió a los satíricos peruanos y tuvo a su cargo la cátedra de Literatura Castellana. En tanto historiador, Porras Barrenechea investigó y contribuyó con sus escritos a conocer mejor la Conquista (incas, conquistadores y cronistas) y la Emancipación (intelectuales y próceres). Asimismo, difundió documentos y fuentes (crónicas, cedularios, cartas). Tuvo a su cargo la cátedra Fuentes Históricas Peruanas. Años después - 1946- dictó el curso Instituciones Coloniales del Perú. Tres fueron sus héroes y personajes predilectos: Pizarro, Garcilaso y Palma. Para él, los tres personajes representaban la peruanidad, dado que, como señaló Franklin Pease, Porras Barrenechea siempre pensaba en una historia integradora. Aquello que era común, aquello que podía ser el hilo conductor, aquello que valía la pena destacar para formar en los peruanos la conciencia de la comunidad política.

Por ejemplo, Pizarro significaba para Porras Barrenechea el espíritu activo que solo mira el futuro, pero que a su vez es víctima de un sino trágico. Respecto a los estudios sobre Pizarro, Rafael Varón sostiene que Porras Barrenechea contribuyó de manera inmejorable en el imaginario peruano, al recuperar la figura de Pizarro con evidencias empíricas estudiadas y encontradas durante largos años de investigación. En sus propias palabras, Porras Barrenechea señala:

Arquetipo del conquistador; heroico, ambicioso, anárquico. Francisco Pizarro es la figura más arrogante de la conquista de América. No hay quien más a tono supiera acordar la vida con la muerte. Hombre de acción, sobre todo, que vivió continuamente en obra, destruyendo o creando, pero en perpetua actividad, sin conocer jamás el reposo absoluto ni el ocio. Y como hombre de acción, espíritu sin amarra ni raíces sentimentales, presto a desligarse de todo, sin más perspectivas que las del futuro, sin mirar nunca atrás en la propia vida ni en la de los otros, fugitivo de sí mismo y de toda intimidad asentadora. Y por eso su inquietud de crear y su falta de compromisos con el pasado. A los 46 años mirando solo adelante, emprende la conquista del Perú, a los 57 inicia la fundación de Lima, Ímpetu sin descanso.

80 Cfr. Lohmann en Varios 1984: 162-163. 
Pocos ejemplos humanos de más adusta y sana honradez, de más recato en el triunfo, de más serenidad en el peligro, de más tenacidad ante el obstáculo y mayor corazón ante la adversidad. Tuvo en el más alto grado esos tres heroísmos que Blanco Fombona ha señalado como distintivos del conquistador español: heroísmo ante los hombres, heroísmo ante la naturaleza y heroísmo ante lo desconocido ${ }^{81}$.

Respecto a Garcilaso y a Palma, en un esfuerzo por relacionarlos y ubicar el valor histórico de cada uno de ellos, dijo un día en el Hemiciclo del Senado:

Ese arte de contar innato lo escogió y plasmó en su obra admirable el Inca Garcilaso de la Vega, uno de los mejores relatores y narradores en lengua castellana, quien dio en $L a$ Florida la mejor prosa narrativa de América, que dijo Menéndez y Pelayo. Ricardo Palma, como Garcilaso, recoge todas las esencias de su tiempo que corresponden al espíritu del Perú. Si Garcilaso fue la fusión de lo indígena y de lo español en el momento de la conquista, Palma fue la fusión de lo español y lo republicano en la época de la independencia y en su obra se refleja no solo la Colonia sino también el alma indígena del Perú [...] todo ese ambiente del Perú antiguo que ya había sido recogido por Garcilaso y que Palma no tuvo ya especial cuidado en revivir. Palma reflejó, también, el ambiente español y colonial, pero lo sintió vivir como criollo y republicano, bajo el signo liberal de la República. Por esta sensibilidad de hombre nuevo del Perú y su formación dentro de los moldes democráticos, Palma auspicia todo lo que vulnera a la autoridad colonial, recogiendo con humorismo exento de rencor todos los desacatos a los virreyes o los errores y liviandades de estos [...]. Interpreta a la colonia con el espíritu de la República y este es uno de sus méritos esenciales. Palma fue un hombre liberal y de línea cívica irreprochable que luchó y sufrió por defender las ideas democráticas al lado de José Gálvez [... $]^{82}$.

La clave a partir de la cual elige a Pizarro, Garcilaso y Palma puede encontrarse en varios elementos. Uno primero, que se trata de hombres nuevos para su tiempo, que por lo tanto tienen que crear y arriesgarse para hacerse un lugar propio. Otro segundo, porque son personajes complejos, con todas las condiciones que justificarían su inacción, pero que se elevan por encima de los límites del contexto y de su propia historia para lanzarse al futuro y apostar por hacer su propio camino. Para Porras Barrenechea, esos aspectos son lo que se deben destacar para influenciar positivamente en el peruano común y corriente. Los eleva a la categoría de arquetipos culturales para que moldeen

81 Cfr. Porras Barrenechea 1978: 32.

82 Cfr. Senado de la República del Perú 1956, segundo volumen: 494-496. 
el espíritu de los peruanos, que, en lugar de ser símbolos de confrontación, signifiquen para los peruanos la fusión de diversas tradiciones, de diversos tiempos. Que en lugar de vivir paralizados por el contexto y el pasado, apuesten por el futuro con tenacidad, superando obstáculos, con serenidad pero con firmeza. De ahí que los tres sean para Porras Barrenechea la encarnación y representación de la peruanidad.

Una última característica del Porras Barrenechea como intelectual fue la de ser un gran maestro, capaz de encontrar y motivar a los alumnos hacia la reflexión crítica, la investigación y el trabajo académico. Cuando Luis Jaime Cisneros fue alumno de Porras Barrenechea del curso Literatura Castellana, recuerda que en las clases cobraban vida cada uno de los literatos cuya obra estudiaban. Incluso decía que con Porras Barrenechea se podía afirmar que "profesar literatura era dirigir una cátedra de valiente optimismo frente a la juventud, y constituía buen pretexto para proponer a la constante reflexión estudiantil aquellos valores por los que el hombre se hace digno de respeto y homenaje» ${ }^{83}$.

Como profesor de Historia, Estuardo Núñez recuerda que las clases de Porras Barrenechea no solo quedaban circunscritas a la hora y al aula de clases, sino que continuaba en comunicación y en la docencia en los patios y pasillos de la Casona de San Marcos. Eso le permitió tener discípulos y muchos seguidores. «Su sentido crítico le permitía descubrir a quienes lucían condiciones sobresalientes y sobre ellos volcaba su interés intelectual, estimulando vocaciones latentes, pero aún no desarrolladas. Por eso dejó discípulos fervorosos e hizo prosélitos de su fe en el Perú, de su deslumbramiento ante la revelación de la historia peruana, de su culto del sentido crítico y de su repulsa ante lo adocenado, lo vulgar, lo ridículo y lo estulto» ${ }^{84}$.

A su vez, y de manera intermitente, enseñó en la Pontificia Universidad Católica de 1933 a 1958. Entre los cursos que tuvo a su cargo en esa casa de estudios fue Historia del Perú en la Facultad de Letras y Pedagogía en 1941. En las aulas de esa casa de estudios, presentó a los cronistas que eran en ese entonces el objeto de sus principales investigaciones, hallazgos y anotaciones.

Como maestro siempre fue generoso hasta el final de sus días. Donó su importante biblioteca a la Biblioteca Nacional, a partir de la cual se organizó la Sala Porras y su casa de la calle Colina a la Universidad Nacional Mayor de San Marcos, en la que ahora funciona el Instituto Raúl Porras Barrenechea.

\section{El PARLAMENTARIO}

Para comprender la presencia de Porras Barrenechea en el Hemiciclo del Senado de la República de 1956 a 1960, es necesario recordar la coyuntura política de ese entonces. Para

83 Cfr. Cisneros en Varios 1984: 167.

84 Cfr. Núnéz en Varios 1984: 75. 
lo cual apelamos a Sinesio López, quien señala que las elecciones de 1956 significan una transición del odriismo al régimen de la convivencia, fueron semicompetitivas en tanto el APRA y el Partido Comunista estaban excluidos de la competencia electoral y poco participativa debido a que si bien las mujeres podían ejercer su derecho al voto, todavía no sufragaban los peruanos analfabetos ni los menores de 21 años.

Además, como la crisis posterior al fin de la guerra de Corea mostró sus efectos en la economía peruana, la oligarquía se distancia de Odría y comienza una etapa de apertura política, especialmente hacia el APRA, de ahí que con el gobierno de Prado se produzcan diversos acuerdos políticos que harán que ese periodo se denomine el régimen de la convivencia ya mencionado.

Porras Barrenechea aceptó ir en una lista por Lima, el Frente Democrático Nacional, encabezada por el "poeta de la juventud» José Gálvez Barrenechea, su tío. En junio de 1956, once días previos a la jornada electoral, lanzaron un manifiesto a los limeños diciendo, según palabras del propio Porras Barrenechea:

[...] Decíamos que queríamos volver a un renacimiento de la conciencia pública y de las fuerzas de opinión para que la voluntad del pueblo vuelva a mostrarse libre y soberana a pesar de las maniobras, de la corrupción, del engaño y del adelanto en la técnica de la falsificación, para dar paso, a un empeño democrático de verdad, que ponga término al abuso del poder y al desdén por el derecho. Decíamos también que lucharíamos contra el personalismo presidencial omnipotente y la viciosa estructura del Estado, para crear un clima cívico de respeto a la ley, en que el Estado no sea opresor de la nación sino servidor de ella ${ }^{85}$.

La lista obtuvo la preferencia de los electores limeños, incluyendo votos apristas. Probablemente, ni el propio Porras Barrenechea intuía, en ese momento, que a partir de ahí ingresaba a un escenario público donde tendría que poner a prueba toda su capacidad de persuasión y de argumentación, donde su voz en varias ocasiones iba a ser aislada, pero firme y diáfana. Donde sus intervenciones en el Hemiciclo serían una prolongación de las aulas universitarias. Demostró independencia de conciencia y de decisión, por lo que ni el gobierno de Prado ni los apristas lograron en él un voto disciplinado.

Dada esa coyuntura política, los primeros temas de la agenda del Senado fue formar una comisión investigadora para que estudie si el gobierno de Odría violó o no la Constitución. Uno de los fragmentos de las brillantes intervenciones de Porras Barrenechea demuestra su capacidad de ubicar a los gobiernos autoritarios en su peso real y la necesidad de hacer una transición hacia la democracia adecuada:

[...] creo yo que el defecto capital de nuestra democracia [...] es el de la falta de adaptación

85 Cfr. Senado de la República del Perú 1956, segundo volumen: 224-235. 
entre las leyes importadas o copiadas del extranjero y nuestra compleja realidad étnica y social, entre la democracia ideal y la irrisoria democracia vivida. Constituidos los gobiernos al margen de la opinión pública, surgen estos sin que exista la comunidad entre la autoridad y el pueblo que brota de todo proceso electoral libre y de ello viene la simulación de las instituciones, la palabrería demagógica junto a la conculcación de las libertades, las triquiñuelas y las mentiras (el llamar bueno a lo malo y malo a lo bueno, negro a lo blanco y blanco a lo negro), el ambiente de hipocresía y de desconfianza ante las fórmulas mismas de represión simuladas y evasivas de la responsabilidad. En los tiempos que nos preceden se ha simulado el sufragio apresando al candidato contrario, se ha simulado la igualdad quitando la ciudadanía a un gran número de peruanos, se ha simulado el respeto a la Constitución encerrándola bajo siete llaves, se ha simulado las libertades de reunión y de opinión proscribiendo a los partidos contrarios, se han simulado las libertades municipales entregando los municipios a los caciques o las oligarquías provinciales o poniendo el derecho de reunión a la discreción de los tanques o de los manguerazos. Todas las básicas instituciones resultan falseadas en nuestro medio por el predominio del provecho personal y la ausencia del propósito del bien común.

[...] El mal proviene de nosotros mismos porque no tenemos un ideal colectivo, una meta segura en el porvenir y, en nuestra incertidumbre del futuro, en la falta de nexos sociales estables y definidos, no sabemos dónde queremos ir juntos y nos debatimos en una perfecta vacilación y discontinuidad de propósitos colectivos.

[...] El mal más grave que produce este conformismo, esta falta de beligerancia contra el abuso, es la improvisación en la vida pública, la selección al revés, el desdén por la tecnicidad y por la inteligencia, el empirismo audaz, el culto de la incompetencia y la falaz y nociva convicción de que no son necesarios para la función pública preparación y estudio y que cualquier compadre puede servir para cualquier función, por alta y especializada que sea, desdeñando los títulos que otorgan las instituciones [...], desdeñando la seguridad que el Estado ofrece a quienes estudian las carreras públicas. Este sistema de la improvisación y del empirismo trajo ya fatales resultados en la primera etapa republicana y se ha acentuado en los últimos años ${ }^{86}$.

Como en todo periodo de transición del autoritarismo a la democracia, también era necesaria la amnistía a presos políticos, de ahí que también se presentara un proyecto de ley de amnistía a militares y civiles procesados y sentenciados por causas políticas y sociales, detenidos con proceso pendiente, y lo más importante, la derogatoria de la Ley de Seguridad Interior, bajo cuya cobertura se había impedido y perseguido cualquier actividad o voz opositora al autoritarismo. En el debate del proyecto, nuevamente la voz de Porras

86 Cfr. Senado de la República del Perú 1956, primer volumen: 101-106. 
Barrenechea apeló a la necesidad de vivir en un país donde la libertad de opinión se respete plenamente y por lo tanto que las opiniones disonantes no tengan que ser condenadas:

[...] Es absolutamente necesario que desaparezca del Perú esa perniciosa costumbre de considerar a los peruanos como menores de edad, como enemigos o como extranjeros, en su propia patria, solo porque no se apoya, no se aceptan, ni se está de acuerdo con sistemas políticos absurdos y arbitrarios. Es necesario, en fin, que termine, definitivamente, esa perenne división de la familia peruana, que ha sido la causa de tantos desastres nacionales y que le hizo exclamar a un eminente general del siglo XIX: 'El Perú está dividido en dos partidos: el de los perseguidos y el de los perseguidores'.

Estoy seguro de que el proyecto de ley en debate [...] ha de ser aprobado por unanimidad. Así terminará esta ominosa etapa de ocho años en que hemos vivido en estado de sitio permanente; no habrán más ciudadanos perseguidos, exilados o desterrados, no vivirá en la prisión el peruano que no piense como el gobierno: no estarán ausentes de la vida y actividad nacional tanto ciudadano eminente, útil y necesario para la patria: se restablecerá el derecho de todos los peruanos; y se cumplirá el precepto constitucional contenido en el artículo 59 de nuestra Carta Magna, que dice 'Nadie será perseguido por razón de sus ideas ${ }^{87}$.

[...] Queremos cumplir un deber fundamental de estirpe ética, de dignidad esencial del hombre, uno de esos deberes de salvación por lo que, según un insigne político americano, la vida vale la pena de ser vivida y por los cuales vale también perder la vida. La vigorización del Estado, la recuperación moral de este y de la sociedad debilitada y empobrecida por el Estado corruptor y desertor de función, necesita ser emprendida con fe y entusiasmo, por una acción sistemática, habitual y constante en defensa del derecho, lo que no es posible realizar si no restablecemos, en primer término, el sentimiento de la responsabilidad. Bien sabemos los riesgos y las amenazas personales que nos circundan. Ellos reflejan la perduración del espíritu de dominio y de intimidación del régimen que acaba de concluir ${ }^{88}$.

Muchas veces fue una voz aislada en el Hemiciclo, cuando todos los demás anteponían intereses y acuerdos particulares a los intereses de la nación. No obstante, lo que dijo no se perdió para la posteridad, porque el Diario de los debates, una de las fuentes más importantes para los estudios de la política y su historia, permite demostrar la actualidad de lo dicho por Porras Barrenechea, y comprobar con pesar que aquello que los peruanos de ese entonces no resolvieron tuvo como efecto pernicioso condenar a las siguientes generaciones a tener que

87 Cfr. Senado de la República del Perú 1956, primer volumen: 101-106.

88 Cfr. Senado de la República del Perú 1956, segundo volumen: 224-235. 
volver a pasar por los mismos problemas, no en una sino en varias ocasiones.

\section{EL DiPLOMÁTICO}

Una de las características de la historia de las Repúblicas de América Latina es que se fundan a principios del siglo XIX como efecto de la crisis política española de 1808, ya que luego de los problemas de soberanía y representación en América y España los virreinatos entran a un proceso de definición política y ruptura con la metrópolis. Ese proceso significa que hay nociones sobre los límites, pero que recién en el siglo XX, producto de conflictos entre los países vecinos y de la participación de otros países, se definirán las fronteras con mayor precisión. Esta particularidad hace que la participación de los diplomáticos peruanos del siglo XX cobre mayor importancia. Alberto Ulloa, Raúl Porras Barrenechea y Carlos García Bedoya, entre otros, tendrán actuación central, en la formación de una carrera diplomática, en la profesionalización y especialización en la Academia Diplomática, y en la preparación de los expedientes que servirán de argumentos al momento de definir y defender los límites del país.

Según cuenta Félix Álvarez Brun, Porras Barrenechea estuvo vinculado al Ministerio de Relaciones Exteriores durante cuarenta años. Ingresó en 1919 a la Cancillería cuando tenía veintidós años y sirvió con dedicación y responsabilidad hasta 1956. Su primer puesto fue auxiliar del Archivo de Límites y poco tiempo después asumió la jefatura, cargo que tuvo hasta 1931. Asimismo, fue bibliotecario del Ministerio de Relaciones Exteriores. En 1924 fue asesor en el plebiscito de Tacna y Arica. Fue asesor de la Comisión de Fronteras de Tacna y Arica. En 1926 fue primer secretario de la embajada peruana enviada a la celebración del Centenario del Congreso de Panamá. En 1957 fue profesor de Historia Diplomática del Perú en la Academia Diplomática, y luego fue miembro del Consejo Superior.

Como señala Alberto Wagner de Reyna, la silueta del Perú es producto de un conjunto de elementos complejos que se han ido produciendo a veces de manera dramática y violenta, a veces de manera pacífica con la ocupación del suelo. Por ello, la figura del mapa no refleja solamente las guerras y los tratados, sino también condensa el periodo Prehispánico, el Hispánico y el Republicano. La ocupación y trabajo en la tierra de los padres que dejan a los hijos un lugar donde vivir y trabajar:

Bulle en sus fríos contornos de nombres y fechas la realidad misteriosa del Imperio incaico, la aventura del conquistador hispano, el murmullo de latines del togado colonial, la rebeldía de los libertadores, la audacia del descubridor y colonizador de las selvas, la fe del misionero, la conciencia del ciudadano, el valor del soldado y la a menudo mal comprendida discreción del diplomático. Todo ello tiene su huella en la silueta del Perú, en la estampa 
de nuestro suelo patrio ${ }^{89}$.

En ese quehacer diplomático, en la búsqueda de documentos que apoyen la posición peruana, Porras Barrenechea tuvo actuación destacada. Sin embargo, de todo ello sobresale aquella que le tocó cumplir al final de sus días, cuando era el canciller de la República y pronunció un discurso en la VII Reunión de Consulta de Ministros de Relaciones Exteriores de los países americanos que se llevó a cabo en Costa Rica. Aquí, hay que recordar que el contexto de la Guerra Fría y la presencia de Estados Unidos en el continente marcan la mitad del siglo XX. Especialmente después de la crisis de los misiles entre Estados Unidos y Unión Soviética en el territorio cubano. Carlos Alzamora y Félix Álvarez Brun, refieren estos episodios de manera notable y a ellos me remito.

En el Perú era el presidente Manuel Prado Ugarteche y el gabinete de ministros estaba liderado por Pedro Beltrán, el ministro de Hacienda. El canciller Porras Barrenechea había presentado males cardiacos, pero estaba resuelto a participar en la reunión de Costa Rica. "iVoy aunque me muera!", dijo a sus discípulos y a los miembros de la delegación peruana que estarían con él. Ello era obvio, así había sido siempre Porras Barrenechea, tenaz y muy consciente de la importancia histórica de los acontecimientos que se estaban desarrollando. En reiteradas ocasiones, tanto en Lima como en Costa Rica había dicho que no estaba dispuesto a "que lo avasallen ni que se arrastre la dignidad del Perú ${ }^{90}$. El 23 de agosto de 1960 pronunció su discurso en primer lugar, por haber sido el Perú el país que había propuesto la referida VII Reunión. Fue un discurso que no había sido aprobado por el gobierno peruano, sino que se sustentaba en la historia de las posiciones que históricamente había mantenido el Perú en sus relaciones diplomáticas. Era su última gran responsabilidad como alto funcionario, y no podía dejar que la presión del momento se antepusiera sobre situaciones de mayor trascendencia. De ahí que su discurso estuvo inmerso en la «trayectoria diplomática de compromiso con la libertad ${ }^{91}$, el respeto a la libre determinación de los pueblos y el principio de no intervención, así como de la vocación conciliadora que siempre mostró.

Luego de pronunciar su discurso, en el ambiente se compartía un espíritu de solidaridad americana tan fuerte que el representante de Estados Unidos informó que estaban solos. Fue tarea de las siguientes horas y días voltear lo que Porras Barrenechea había provocado. Hasta que la Declaración de San José expresó el triunfo de Estados Unidos, documento que no fue suscrito por Porras Barrenechea, quien, a su vez, renunció a su cargo de ministro de Relaciones Exteriores, pero que no fue aceptada.

89 Cfr. Porras Barrenechea y Wagner de Reyna 1981: 2.

90 Cfr. Alzamora 2000: 93.

91 Cfr. Alzamora 2000: 101. 
Luego vino el retorno a Lima, la aceptación de la renuncia, la agonía de Porras Barrenechea y finalmente su muerte el 27 de setiembre de 1960. Murió con la conciencia tranquila de haber cumplido con su país, así dicen todos los que lo recuerdan con afecto y admiración, y siempre será recordado por ello.

\section{ConClusiones}

En el ámbito intelectual, diplomático y político, Porras Barrenechea se comportó como un maestro en el pleno sentido de la palabra. Planteó problemas, buscó la verdad, invitó a la reflexión e incentivó a los que lo rodeaban a conocer el país y su población, a respetar la cultura, pero especialmente a respetar la democracia y las libertades de los ciudadanos y ciudadanas.

Como miembro de la comunidad política de los peruanos, actuó como un ciudadano cabal. Supo asumir la representación política otorgada por los electores limeños en el momento en que sintió que era su deber comprometerse con el país para volver a la democracia después que se había vivido ocho años del autoritarismo de Odría.

Así como Porras Barrenechea participó activamente en la Celebración del Centenario de la Proclamación de la Independencia del Perú y el Centenario de la Batalla de Ayacucho, a las generaciones actuales nos toca celebrar como es debido el bicentenario de ambos acontecimientos.

Recordar a Porras Barrenechea, como uno de los principales intelectuales del Perú del siglo XX, es apostar por la construcción de una comunidad que sabe reconocer a sus hombres y mujeres que contribuyeron - en las tareas que desempeñaron- a establecer los hitos centrales de nuestra peruanidad. A cuarenta y ocho años de su muerte, aún lo recordamos a través de los diversos homenajes que se han realizado, con la publicación de reediciones de su obra, con encuentros académicos que reflexionan sobre sus aportes, colocando su nombre en lugares de recordación.

En las generaciones de peruanos de hoy y de mañana descansa la responsabilidad que no se no se pierda la memoria sobre Raúl Porras Barrenechea ni sus lecciones de peruanidad.

\section{Bibliografía}

ÁLVAREZ BRUN, Félix (1997). Raúl Porras, diplomático e internacionalista. Lima: Universidad Nacional Mayor de San Marcos.

ALZAMORA, Carlos (2000). La agonía del visionario. La lección final de Raúl Porras. Lima: El Virrey.

CASALINO SEN, Carlota (1999). Raúl Porras Barrenechea, parlamentario. Lima: Fondo Editorial del Congreso de la República del Perú. 
GARRIDO ARANDA, Antonio (2001). A propósito de Raúl Porras Barrenechea. Córdoba, España: Universidad de Córdoba.

PORRAS BARRENECHEA, Raúl (1974). Los ideólogos de la emancipación. Lima: Editorial Milla Batres.

(1978). Pizarro. Prólogo de Luis Alberto Sánchez. Lima: Editorial Pizarro.

(1997). Perspectiva y panorama de Lima. Lima: Entre Nous.

PORRAS BARRENECHEA, Raúl y WAGNER DE REYNA, Alberto (1981). Historia de los limites del Perú. Lima: Editorial Universitaria.

SENADO DE LA REPÚBLICA DEL PERÚ (1956). Diario de los debates. Primera legislatura ordinaria, primer y segundo volumen. Lima: Senado de la República del Perú.

VARIOS (1984). Homenaje a Raúl Porras Barrenechea. Lima: Universidad Nacional Mayor de San Marcos.

La vida de Luis Alberto Sánchez (LAS) transcurrió, en un primer momento, entre la enseñanza y la investigación académica. Empezó como profesor de secundaria en el Colegio de Lima, más tarde Labarthe. Luego en el Deutsche Schule o Colegio Alemán. Fueron sus alumnos: Martín Adán, Emilio Adolfo Westphalen, Guillermo Lohmann Villena, Es- 



\section{Luis Alberto Sánchez \\ (1900-1994) \\ Ismael Pinto Vargas}



tuardo Núnez, los hermanos José («Vicente Azar») y Jerónimo Alvarado Sánchez, Carlos Cueto Fernandini, Eugenio, Gerardo, Antonio y Luis Felipe Alarco, Alberto Wagner de Reyna, entre otros.

Catedrático en la Universidad Nacional Mayor de San Marcos, fue decano de la Facultad de Letras y tres veces su rector. Dejó huella indeleble por la cátedra, la crítica literaria, la historia, el ensayo, la novela, la biografía novelada, las traducciones, el periodismo y, finalmente, la política y el periodismo radial y televisivo. La política le conllevó a más de un forzado exilio. De allí que fue, a su pesar, un profesor trashumante de universidades, ya de este lado del mundo, como de la vieja Europa. En lo que a política se refiere, podemos decir que fue un intelectual politizado, o al revés, siempre en el más alto y digno sentido de esta aseveración. Aunque mejor sería recordarlo como el hombre que supo, con pasión y entrega, dar a cada cual el espacio que realmente le correspondió en su larga vida.

LAS es un personaje al que la crítica y los críticos han señalado, como las características más saltantes de su personalidad, su extraordinaria formación humanista, su asombrosa memoria, su elegancia y facilidad de palabra en la tribuna y en la cátedra, como igualmente su sápida verba de limeño viejo, y su irrepetible y vivísima capacidad de respuesta ante el ataque o el halago.

Con LAS se empieza en el Perú el estudio sistemático de la crítica literaria del siglo $\mathrm{XX}$. Es su iniciador indiscutible y de él parten, por más que se le ataque y ningunee, todos los caminos para estudiar nuestro desarrollo literario. No olvidemos, con palabras de Pablo Macera, que en cada error de Sánchez hay más inteligencia que en todas las carretadas de falsa erudición de sus críticos. Acertadamente, LAS llamó a su monumental obra La literatura peruana. Derrotero para una historia cultural del Perú. En este campo su trabajo es realmente irrepetible: la literatura como un hecho social, que más tarde se «descubrirá» y pondrá de moda. Más aun hoy, cuando todo se reduce a pequeñas y limitadas monografías o ensayos, bajo la influencia neomarxista o de lo último que dicta la moda de las universidades estadounidenses, inglesas o francesas. La obra de LAS en ese campo solo es comparable a la que nos han dejado Basadre, Vargas Ugarte o Porras Barrenechea.

LAS fue un peruano del siglo XX, como él mismo se autocalificó al poner a sus memorias como título Testimonio personal, que, en buena cuenta, son el registro casi notarial 
como también el espejo espléndido del largo y tumultuoso tiempo que le tocó vivir. Y lo admirable de LAS es que lo que allí registra no es un testimonio de oídas de, te lo cuento como me lo contaron. Por el contrario, es el testimonio de un testigo de cargo.

LAS fue un peruano que vivió a plenitud todo el siglo XX y sus avatares. También sintió el hálito y las voces antiguas del siglo XIX que no querían marcharse. Al fin de sus fecundos años, avizoró y sintió el rumor cambiante de todo lo que traía el nuevo siglo XXI. Luego se apagó serenamente lúcido, sin odios, ni rencores. Se marchó de este mundo como cristiano viejo — nunca dejó de serlo- sin temerle a la muerte y en paz con su conciencia. Iba con la alforja liviana y con la fe primera que nunca abandonó.

\section{NotiCIA BIOGRÁFICA}

Luis Alberto Sánchez y Sánchez nació en Lima el 12 de octubre de 1900. Falleció el 2 de febrero de 1994, en Miraflores. Su padre fue Alberto Sánchez, y su madre, Margarita Sánchez. Fue alumno de La Recoleta. Le habían antecedido en esas aulas José de la Riva-Agüero y Osma, los hermanos García Calderón: Francisco, Ventura, José y Juan, también Juan Bautista de Lavalle, Eduardo Barrios Hudtwalcker, Mansueto Canaval, Raymundo Morales de la Torre y otros. Y, cercanamente, Manuel Beltroy, Raúl Porras Barrenechea, Pedro Beltrán Espantoso, Javier Correa Elías y Manuel Pardo Heeren. La precocidad intelectual de LAS y su facilidad para escribir se puso de manifiesto desde 1909. Estando en el segundo año de primaria publicó una serie de cuentos y estampas patrióticas en el Boletín Escolar de La Recoleta.

\section{EL UNIVERSITARIO}

En marzo de 1917 LAS se matriculó en la Universidad Nacional Mayor de San Marcos. Se iniciaba una relación amorosa que jamás se rompería, no obstante las ingratitudes de su amada. En San Marcos conoció a Haya de la Torre, Manuel Seoane y César Vallejo, como a todos aquellos que formaron el Conversatorio Universitario.

En el centro universitario frecuentó a Abraham Valdelomar y se hizo asiduo visitante del Palais Concert y del Morris Bar. Ezequiel Balarezo Pinillos, mejor conocido como Gastón Roger, lo invitó a colaborar en la Revista de Actualidades. Allí publicó su texto «El cantor del barrio», dedicado a Evaristo Carriego. Su espaldarazo en serio se lo proporcionó «Comentarios sobre 'El Caballero Carmelo' y su autor, Abraham Valdelomar», que lanzó en El Tiempo. Ladislao Mesa, conocido y prestigioso periodista, lo presentó a José Carlos Mariátegui y a Alfredo González Prada.

Ese fue el tiempo en que LAS conoció y frecuentó a José de la Riva-Agüero y Osma, catedrático de Historia del Perú en San Marcos. La amistad se interrumpió cuando Riva-Agüero se marchó a Europa, a raíz del golpe de Estado que derrocó a Pardo y encumbró a Leguía. En 1930, Riva-Agüero volvió a Lima después de su largo autodestierro. Si bien aquella relación 
prosiguió, los cambios que se operaron en la historia del Perú le trajeron cambios profundos. Don José se acercó a Sánchez Cerro. LAS, ya aprista confeso, marchó al exilio.

\section{El Conversatorio Universitario}

La empatía y la amistad de LAS con Jorge Guillermo Leguía, Raúl Porras Barrenechea, Haya de la Torre, Ricardo Vegas García, el moqueguano Manuel Abastos, Guillermo Luna Cartland, Carlos Moreyra Paz Soldán, José Luis Llosa Belaunde, José Quesada y Jorge Basadre, sanmarquinos todos, motivó que, teniendo como escenario la casa de Porras Barrenechea, formaran el Conversatorio Universitario o de la Primera Reforma Universitaria. En histórica fotografía, la revista Mundial registró la imagen del grupo en julio de 1921, año del centenario de la independencia.

Los del Conversatorio tenían por meta estudiar la historia del Perú, dejando de lado la historia oficial. También rescatar San Marcos del civilismo y romper el nepotismo en que se encontraba sumida la universidad. Al mismo tiempo que integraba el comité directivo de la Reforma Universitaria, LAS ingresó a trabajar como secretario contador de la Biblioteca Nacional del Perú; Alejandro Deustua era el director.

El Conversatorio realizó serios trabajos de investigación. Así, LAS leyó «Los poetas de la revolución». Lo habían antecedido Jorge Guillermo Leguía, con «Lima en el siglo XVIII», y Raúl Porras Barrenechea, con «Don José Joaquín Larriva», las tres únicas conferencias impresas. En 1921, el del centenario de la independencia, San Marcos fue recesado por el gobierno. LAS, Porras Barrenechea y Haya se opusieron a esta medida. En 1922, estos mismos jóvenes, incluyendo LAS, se reunieron para la reapertura de la universidad.

\section{EL VIAJERO}

En 1923, LAS, con Alejandro Belaunde y Carlos Aramburú Salinas — hermano del dueño y director de Mundial-, programaron la publicación del volumen El mundo bolivariano, un viaje tras las huellas de Bolivar, para conmemorar el centenario de la batalla de Ayacucho.

\section{San Marcos, Amauta, Mundial y Mariátegui}

En 1925, LAS se recibió de bachiller en Jurisprudencias con la tesis La Ley 4916 y las leyes de trabajo en Chile e Italia. En 1926, se graduó de abogado. Aparece el testimonio de su largo viaje a Colombia, Venezuela, Panamá y Ecuador — recorrido que originó la amistad de LAS con conspicuos personajes de las letras y las artes venezolanas - en un pequeño y muy sabroso volumen: Tras las huellas del Libertador.

En 1926, ingresó como profesor a la Universidad Nacional Mayor de San Marcos. Dictó el curso de Literatura Peruana y Americana, que había dejado José Gálvez. Ese 
año apareció Amauta, de Mariátegui.

En 1927, ocurrió la pública y comentada polémica que se suscitó en las páginas de Amauta, entre LAS y Mariátegui, que insistía en construir el nuevo Perú sobre la base de un indigenismo trasnochado y una hispanofobia furibunda. A LAS se le levantó el cholo y salió a decir lo suyo en «Batiburrillo indigenista». La polémica fue recogida por LAS en 1976, en el volumen La polémica del indigenismo. LAS anota: «Nuestra polémica no nos alejó [...]. Él [Mariátegui] era demasiado inteligente y yo no era tonto como para convertir una divergencia ideológica en querella personal».

Ese año inicia su monumental trabajo: La literatura peruana. Derrotero para una historia cultural del Perú, que crecerá y perfeccionará en cada nueva edición. El trabajo colocó al joven investigador y crítico en una promisoria y expectante situación, dueño de un envidiable prestigio. Había llegado demasiado pronto hasta donde muchos no alcanzaban con toda una vida. En la introducción a este trabajo, LAS anotó: «Busco la raíz de muchos fenómenos en el pueblo, porque creo que la literatura es, ante todo y sobre todo, un fenómeno social, de origen popular».

En 1929, LAS publica «Se han sublevado los indios» $\mathrm{y}$ «Esta novela peruana» con Equivocaciones de Basadre, un singular e innovador trabajo, que tenía mucho que ver con el movimiento vanguardista. Fue igualmente el año en que, aprovechando que el escritor liberal estadounidense Waldo Frank había sido invitado a Buenos Aires, Mariátegui y LAS constituyeron en Lima el grupo Amigos de Waldo Frank, para traerlo al Perú, hecho que consiguieron.

A fines de 1930, LAS, invitado por la Universidad de Chile para dictar un ciclo de conferencias en Santiago, fue portador de una carta que Mariátegui le escribía a Seoane, instándolo a romper con Haya y sumarse al nuevo partido que construía. El mensajero se mantuvo al margen de esa pelea. A su retorno a Lima, portando una invitación de la Universidad de Chile para Mariátegui, como paso previo para recalar en Buenos Aires, encontró LAS que el amigo entrañable había sido enterrado dos días antes de su arribo.

\section{LAS EN LA POLÍTICA}

El levantamiento del comandante Luis M. Sánchez Cerro y el derrocamiento de Leguía, en agosto de 1930, permitió que los desterrados volvieran al Perú. Por razones de amistad con Seoane, Manuel Vásquez Días, Carlos Manuel Cox y otros, el estudio del flamante abogado que era LAS se convirtió en centro de actividad política aprista. La reacción palaciega no se hizo esperar, lo que originó que, sin serlo, LAS sufriera la represión y estuviera entre los perseguidos apristas.

En marzo de 1931, LAS se inscribió en el Partido Aprista Peruano — convirtiéndose con el paso del tiempo en uno de sus líderes históricos, como Haya, Seoane, Cox y 
otros-, agrupación política que adscribiría toda su vida. Fueron momentos políticamente duros, ya que la represión con nuevos destierros no se hizo esperar. El team Seoane-LAS dio vida a La Tribuna, vocero oficial del Partido Aprista. El primero como director, el segundo como subdirector.

En San Marcos, elegido José Antonio Encinas como rector - el otro candidato fue Víctor Andrés Belaunde-, nombró a LAS director de Extensión Universitaria. LAS desarrolló una intensa campaña cultural; fue la presencia y la influencia benéfica de la universidad, más allá de sus centenarios claustros y del patio de las protestas juveniles.

El 8 de diciembre de 1931 LAS ingresó por vez primera al Congreso de la República. Con los años sería diputado, senador, presidente del Senado y, antes del fin de sus días, constituyente una vez más y primer vicepresidente de la República. Desde ese sitial, en algún momento, LAS propició un acercamiento entre Haya y Riva-Agüero, que se frustró por la impuntualidad del primero. En febrero de 1931, los congresistas fueron defenestrados y desterrados rumbo al norte: LAS, Seoane, Spelucín, Cox. LAS recaló en Panamá. Allí sobrevivió dando conferencias, dictando cursillos en el Instituto Nacional — de donde salieron dos libros: Vida y pasión de la cultura en América y Panorama de la literatura actual - y escribiendo para La Estrella de Panamá.

Producida la revolución de Trujillo en 1932, LAS viajó de Panamá a Guayaquil, donde se hallaba un fuerte grupo de desterrados apristas. De allí, en compañía de su amigo el poeta Gilberto Owen, cónsul de México en Guayaquil, se trasladó a Quito. Sin volver al Perú, permaneció allí un año y un mes, tiempo en que fungió de periodista — con el seudónimo de «Juan Fernández»— en El Día, de Quito

Muerto violentamente Sánchez Cerro en el hipódromo de Santa Beatriz, tomó el mando el general Óscar R. Benavides, recién desempacado de Europa. Se dio una ley de amnistía para los perseguidos políticos que vivían en el Perú, pero los desterrados tuvieron que esperar algo más de tiempo. En setiembre de 1933, LAS desembarcaba en el Callao de su primer destierro.

\section{INTERMEZZO CON NUEVO DESTIERRO}

Con San Marcos recesado, La Tribuna clausurada y sin libertad de acción —el APRA seguía perseguida—, su estudio de abogado abandonado y con sus clientes amenazados, LAS tuvo que vivir un tanto a salto de mata, a pesar del lema del gobierno, «Paz y concordia». Roto su primer matrimonio, en 1934 LAS se casó con Rosa Dergan, la mujer que lo acompañaría hasta el final de sus días.

Ante la reacción del gobierno de no querer cambiar las cosas, y no obstante las conversaciones de Haya con Benavides y los buenos oficios de los amigos de unos y otros, lo real era que se vivía una nueva dictadura con muertos, heridos y perseguidos. Se planeó 
una nueva insurrección para «remediar» las cosas. LAS se volvió un eficiente conspirador.

LAS fue a dar a la Intendencia de Lima y de allí al destierro. Cuando le preguntaron adónde quería que lo desterraran, LAS sugirió el norte; lo enviaron a Chile. Allí tenía cobija y trabajo asegurado. Buenos amigos lo esperaban.

\section{Los libros de ERCILla}

Laureano Rodrigo, antiguo amigo y cliente de LAS, y director de la Editorial Ercilla, en Santiago, lo contrató. Primero como jefe de propaganda, y luego como asesor literario, corrector de originales, cogerente, traductor y componedor en el pago de derechos de autor, hasta llegar a codirector; allí conoció a fondo la literatura y la política chilenas. Las Escuelas de Temporada de la Universidad de Chile llamaron a LAS para que dictara el curso de Literatura; antes, como profesor extraordinario, había ya dictado el de Literatura Peruana en el Instituto Pedagógico.

Las necesidades de la crecida familia Sánchez exigían a LAS trabajar sin tregua ni descanso. En esos cinco años de descielado — a decir de Unamuno-, publicó Haya de la Torre o el político (1934), Panorama de la literatura actual (1934), Vida y pasión de la cultura en América (1935), Breve tratado de literatura general (1935), La Perricholi (1936), La literatura peruana (1936, en tres tomos), Historia de la literatura americana (1937), Dialéctica y determinismo (1938), Garcilaso Inca de la Vega (1939), Historia general de América (1942), Valdivia, el fundador (1941), Una mujer sola contra el mundo (1942), El pueblo en la revolución americana (1943), Un sudamericano en Norteamérica (1943) y ¿Existe América Latina? (1945). Intensa labor que admirablemente compaginó con traducciones de libros de Romain Rolland, André Maurois, Waldo Frank, Nikos Kazantzakis, André Malraux, Rainer Maria Rilke y James Joyce. «Mi maquina de escribir fatigaba los oídos de los vecinos. Mi lámpara brillaba hasta altas horas de la noche. Tenía los dedos encallecidos [...]. Escribir era mi opio y mi cocaína», anotaría LAS muchísimos años más tarde.

Motivos de trabajo, aumentar la economía familiar y también menesteres de la política llevaron a LAS a Buenos Aires. De allí sus lazos amicales con Alfonso Reyes, Pedro Henríquez Ureña, Enrique Díez-Canedo, Giuseppe Ungaretti, Ramón Gómez de la Serna y toda la intelectualidad porteña. Montevideo fue otra memorable pascana; allí entabló contacto con los más conspicuos intelectuales y líderes políticos.

En el segundo semestre de 1936 Pablo Neruda retornó a Santiago; venía de España. La Guerra Civil había dividido a políticos e intelectuales. Unos apostaban por la República, otros por el fascismo y Franco. Chile también tenía su pequeña guerra civil, la que originaban los grupos de poetas y escritores y pintores cercanos a Neruda, a Vicente Huidobro y a Pablo de Rokha. Como codirector de Ercilla, LAS supo capear las encrespadas aguas de esa permanente tormenta intelectual: publicó las obras del uno como del otro. En verdad, las relaciones con Huidobro fueron más cálidas y familiares, lo que no impe- 
día que Neruda visitara la casa de los Sánchez para comer arroz con pato con cuchara. A fines de 1937 Neruda retornó a España. De París, Vallejo escribió a LAS para que asistiera en representación de los escritores peruanos al Congreso de Intelectuales Antifascistas, que se realizaría en Valencia. El viaje se truncó, ya que el cónsul peruano en Santiago no se atrevió a visar el pasaporte de LAS.

\section{El PROFESOR VISITANTE}

LAS se abocó a viajar a Estados Unidos, invitado por el poeta Archibald MacLeish, de la Biblioteca del Congreso. El más entusiasta de que aquel viaje se realizara fue Alfredo González Prada. En Nueva York, lo esperaban Waldo Frank, Román Cossio del Pomar y otros. De Alfredo González Prada no se tuvo noticia. LAS sí se entrevistó con Adriana de González Prada, que tampoco sabía dar razón de su unigénito.

De Nueva York, LAS se trasladó a Washington. Su trabajo en la Biblioteca del Congreso tenía como vecinos asiduos conversantes a John Dos Passos, Thornton Wilder y al notable historiador Lewis Hanke. También había sustanciosas reuniones en Alexandría, en la casa de Concha Romero, responsable de la Biblioteca de la Unión Panamericana, donde recalaban Henry A. Wallace, vicepresidente de Estados Unidos; el español Julio Álvarez del Bayo, ex ministro de Relaciones Exteriores de la República; el poeta Archibald MacLeish y otras conspicuas personalidades de las letras y la política.

Prado viajó invitado a Estados Unidos. La política del buen vecino de Franklin D. Roosevelt trataba de ganarse las simpatías de los latinoamericanos. LAS fue tentado por gente del gobierno estadounidense para una posible conversación con Prado. Calculando para que esta no se llevara a cabo tal como se la habían programado, en Nueva York LAS conversó a la pasada con Prado, que iba al hipódromo; este le propuso reunirse al día siguiente. No fue posible: LAS había sacado pasaje para retornar a Chile. Prado le sugirió que la conversación se realizara en Lima.

\section{El RETORNo a Estados Unidos}

LAS volvió a la Editorial Ercilla, al periodismo y a la política. Al finalizar 1943 y ante la posibilidad de retornar al Perú o de aceptar trabajo en Estados Unidos, se decidió por lo primero. Vendió su casa y, casi al mismo tiempo, le alertaron que había llegado un cable al consulado que decía escuetamente: «Absténgase de visar pasaporte de Luis Alberto Sánchez y familia». Las cosas se complicaban. Alfredo González Prada se había suicidado y la madre de este le instaba que fuera a Nueva York. Fue en esas circunstancias en que LAS recibió un contrato para ser profesor visitante del Michigan State College; lo firmó.

La Navidad de 1943 fue el último día que los Sánchez permanecieron en Santiago. Al otro día viajaron por avión a Lima, donde estarían hasta el 2 de enero, cuando LAS y su 
esposa partieron rumbo a Estados Unidos. Fue un Año Nuevo ingrato. En esas circunstancias invitaron a LAS a una cena de fin de año. Como siempre, Haya llegó tarde, a las dos de la mañana, y no hubo tiempo de conversar. LAS partía a las cinco de la madrugada. Antes, el recibimiento que tuvo LAS por parte de algunos compañeros fue desconcertante, por decir algo. Tanto así, que luego anotaría: «Me pareció que no me hallaba entre compañeros, sino entre pesquisidores».

Vía Panamá, LAS arribó a Nueva Orleans, de allí hasta Chicago y, finalmente, su destino, el East Lansing, un pequeño, bucólico y conservador suburbio de Lansing, la capital del estado de Michigan. Allí, aburrido, aguantó un semestre. Aceptó una invitación de Jaime Torres Bodet, a la sazón secretario de Educación Pública de México. Fue un volver a dialogar con Alfonso Reyes, Jesús — don Chucho— Silva Herzog, Rafael Heliodoro Valle, Daniel Cosío Villegas y con su entrañable Gilberto Owen.

En México estaban los desterrados Manuel Vázquez Díaz, Alberto Grieve, José Russo Delgado, Cossio del Pomar, Cachito Bedoya y el socialista Luciano Castillo. También hubo una reunión con los camaradas de generación, como Carnero Checa, Jacobo Hurwitz y, el más importante, Lombardo Toledano. Allí le llegaron los apremios de don Federico de Onís, que lo instaba a realizar su trabajo para doblar las películas de la Metro Goldwyn Meyer; de doña Adriana, para que retornase a Nueva York so pena de suicidarse; desde Chile, pues los de Ercilla le hacían saber que ya no podían prolongarle más el permiso; y, finalmente, el partido, que lo instaba a la labor política, ya que en 1945 había un proceso electoral. En tanto, algunos amigos de Benavides y suyos manifestaron el interés del primero en tener una reunión con el joven profesor desterrado.

\section{EL HiJO PRÓdigo}

LAS recaló en Lima. Debía hablar con Haya antes de entrevistarse con Benavides. La reunión se concretó y se habló de fletar la candidatura de Bustamante y Rivero a la presidencia de la República, respaldado por el Frente Democrático Nacional, que agrupaba a los apristas — fuera de la ley_ y a los otros partidos: leguiistas, sanchezcerristas, descentralistas, demócratas, benavidistas e independientes; no se tomó en cuenta a los camaradas.

LAS se quedó en Lima y, con el visto bueno de Haya, empezó una frenética carrera de componedor político hablando con unos y otros. Finalmente decidido el apoyo a Bustamante y Rivero, se aceptó que el APRA volviera a la legalidad. Para el naciente Congreso de la República, LAS fue postulado como diputado; tuvo una abrumadora votación, tanto que Haya, con cierto retintín, le dijo: «Caramba, que popular eres!». LAS, que no se mordía la lengua, le replicó: «La gente se equivoca mucho».

El mejor síntoma de que las cosas habían cambiado fue que a LAS le devolvieran su cátedra en San Marcos. Luego, accedió al decanato de la Facultad de Letras, que fue el 
camino más seguro para llegar, en mayo de 1946, al rectorado. Fue en aquel tiempo que LAS consiguió el terreno - un millón y medio de metros cuadrados- donde hoy se levanta la Ciudad Universitaria de San Marcos; además, estableció un fondo intangible de cinco millones de soles de aquel entonces. Por otro lado, siendo San Marcos un termómetro político y un centro de agitación estudiantil, el gobierno desató una ofensiva en su contra, sin cuartel y sin descanso. Se culpaba a LAS de todo cuanto hacían los estudiantes, por comisión y por omisión. En medio de toda esa batahola, LAS se dio tiempo para trabajar y publicar El señor Segura, hombre de teatro.

Mientras tanto, las relaciones entre el Ejecutivo y el Partido Aprista, que tenía mayoría en el Congreso, se agriaban cada día más. Bustamante y Rivero no hacía nada por arreglar las cosas, sí por empeorarlas. Se hablaba de intervenir San Marcos y del golpe del ministro de Gobierno y Policía, general Manuel A. Odría, quien ya esperaba dar el zarpazo.

El 3 de octubre de 1948, se sublevó la escuadra en el Callao, cuando un grupo en desconocimiento de Haya y de la dirigencia, en connivencia con algunos marinos, militares, y civiles, empuñó las armas. El motín fue develado a sangre y fuego. La persecución, encarcelamiento y destierro a los dirigentes del partido no se hizo esperar.

LAS se asiló en la embajada de Paraguay, país en donde su amigo Juan Natalicio González era el flamante presidente de la República. El 23 de octubre de 1948 pisó tierra paraguaya. Empezaba su tercer destierro.

\section{OTRA VEZ EN EL CAMINO}

Este tercer destierro se caracterizó por su inaudita movilidad. LAS vivió, de 1948 a 1960, todas o casi todas las peripecias que soportó la democracia en América Latina. LAS vivió de cerca los intríngulis internos del APRA, donde algunos de sus miembros entusiasmados apostaban por Perón como el sucedáneo del APRA, lo cual LAS no adscribió y combatió en todo momento, creándole animadversiones y ataques, hasta el distanciamiento con Seoane. Haya de la Torre se hallaba confinado e incomunicado en su asilo de la residencia del embajador de Colombia. De Asunción, LAS se trasladó a Guatemala, donde estaba de presidente su amigo Juan José Arévalo. Siguió su viaje a Puerto Rico, donde le ofrecieron generosamente una cátedra en la Universidad de Río Piedras, y nuevamente a Nueva York, para ser conferenciante en la Universidad de Columbia.

LAS bajaba de un avión para inmediatamente subir a otro, a dictar conferencias, cursillos, a organizar la famosa Conferencia de Partidos Democráticos de La Habana. En 1951, retornó a Puerto Rico, donde publicó La universidad no es una isla. En Río Piedras traba amistad con Juan Ramón Jiménez. Un año después está en México, realizando un estudio sobre educación para el gobierno; de allí a la Universidad de La Habana como profesor visitante. Otra vez lo tenemos en Chile y en la universidad; publica su Proceso y contenido de la novela hispanoamericana. Va y viene una y otra vez a Buenos Aires, Mon- 
tevideo, Río de Janeiro, La Habana y Puerto Rico. Es el momento en que es nombrado miembro del Congreso por la Libertad de la Cultura, que primero se reunió en Milán y luego en La Habana. Reencuentro y nuevas amistades: Germán Arciniegas, Salvador de Madariaga, Luis Araquistaín, Ignacio Silone, Stephen Spender, Raymond Aron, Bertrand Russell, Willy Brandt, François Bondy, Julián Gorkin y tantos otros. En la práctica, el congreso era un frente para contrarrestar la influencia de los comunistas en el mundo de la cultura. LAS publica su Haya de la Torre y el APRA.

La dictadura, primero abierta, luego edulcorada, del general Odría duraría ocho años: el Ochenio. No obstante, al terminar el mandato constitucional, ya se vislumbraban a posibles sucesores. Los más notorios eran Hernando de Lavalle, amigo cercano de Haya, y, otra vez, Manuel Prado; por su lado, Fernando Belaunde Terry se dejaba caer. Haya, desde París, era el gran elector.

\section{SAN Marcos otra VeZ}

El 28 de julio de 1956 el APRA estaba nuevamente dentro de la ley. Los desterrados podían retornar. El 7 de agosto LAS pisaba nuevamente tierra peruana. Una vez más le fue devuelta su cátedra en San Marcos, después de ocho años de ausencia. LAS estuvo muy ocupado la segunda mitad de la década de 1950 asistiendo a reuniones, ya en México D. F., ya en París, o dictando cursos y conferencias, o viajando como invitado por instituciones y gobiernos, tal el viaje a Israel. Es también su descubrimiento de España. Entre viaje y viaje, la Universidad Nacional Mayor de San Marcos vuelve a ser su preocupación; no olvidemos que fue un rector desterrado sin cumplir su periodo lectivo.

A todo esto, en 1958 fungió como decano interino de la Facultad de Letras. Ese año, publica dos trabajos: Perú: retrato de un país adolescente y Escritores representativos de América. En 1959, lo tenemos en Nueva York, en la Universidad de Columbia; luego en Francia, en La Sorbona, como profesor invitado.

En este último viaje tiene un nuevo encuentro con Haya. Al retornar a Lima y entrevistarse con su primo el canciller Manuel Cisneros Sánchez, y expresarle el deseo de Haya de volver al Perú, se dio con la sorpresa de que Haya seguía siendo un apestado. No obstante, «El Viejo» volvió. LAS fue elegido decano titular de la Facultad de Letras de San Marcos.

El de 1959 fue un año malo para LAS. Murieron Alfonso Reyes, en México; luego Ventura García Calderón, en París. En 1960, recibe el Premio de Fomento a la Cultura, por su valioso trabajo Aladino o vida y obra de José Santos Chocano. Las opiniones estaban divididas en el Partido Aprista: entusiasmo y pesimismo, después de la caída de Batista en Cuba, y el triunfo de Fidel Castro, que había recibido fuerte apoyo de Rómulo Betancourt, de José Figueres, de Carlos Prío Socarrás, demócratas libres de toda sospecha. El resultado final es por todos conocido. Una dictadura marxista en busca del paraíso que 
dura más de medio siglo.

En abril de 1960, el Congreso había aprobado la nueva ley universitaria, Ley 13417, que ordenaba que cada universidad elaborase sus propios estatutos. LAS salió elegido presidente de la Asamblea Universitaria. Por renuncia de Aurelio Miró Quesada Sosa, al cual ni los comunistas ni los apristas dejaron trabajar, en abril de 1961 se llamó a elecciones. Obviamente, LAS fue candidato con mayor opción. Su opositor, fletado por los partidos contrarios al APRA, fue René Boggio Amat y León. LAS salió elegido con noventa y dos votos, y el 12 de mayo ocupó por segunda vez el sillón de Pedro de Peralta Barnuevo Rocha y Benavides, quien en la historia de la universidad es el único sanmarquino en haber sido rector hasta en tres oportunidades. LAS le iba a la zaga.

La política irrumpe nuevamente. Haya (APRA y el Movimiento Democrático Peruano), Belaunde (Acción Popular) y Odría (Unión Nacional Odriista) son los candidatos para la presidencia de la República, que en breve tiempo debería dejar Prado. Realizadas las elecciones, Haya fue el virtual triunfador. Acicateadas por los perdedores, por intereses de grupo y por algún medio televisivo, las Fuerzas Armadas, una vez más, se convirtieron en el gran elector. El general Nicolás Lindley, comandante del Ejército, comunicó a los directivos del canal 13 que, según la proyección hecha por la Fuerza Armada, el ganador era Belaunde. El presidente Prado llamó a Haya a Palacio. Le comunicó su triunfo y también que la Fuerza Armada lo vetaba.

LAS estuvo en las distintas reuniones que de alguna manera trataron de arreglar la intromisión castrense en las elecciones con la oposición de Belaunde, quien, de todas maneras, quería la presidencia. Ante la posibilidad de un entendimiento y para evitar un cuartelazo, finalmente, mientras estaban reunidos en Villa Mercedes, para llegar a un acuerdo y resolver ese impasse que afectaba a la democracia en el Perú, los personeros de Belaunde —Guillermo Hoyos Osores, Manuel (Manongo) Mujica Gallo_-, con Haya, LAS, Seoane, Grieve, Prialé, Villanueva y Cox, se dieron con la sorpresa que Belaunde se había sublevado en Arequipa; exigía su triunfo, decretaba una huelga política y llamaba al Ejército en su ayuda. La huelga fracasó; pero el cuartelazo no. De facto se anularon las elecciones por ser fraudulentas.

No obstante la renuncia de Haya, los militares defenestraron a Prado. Los parlamentarios elegidos democráticamente igualmente fueron extraídos del Congreso. Y en lugar de un presidente libremente elegido, teníamos en Palacio a los generales Pérez Godoy y Lindley, el almirante Torres Matos y el teniente general FAP Pedro Vargas Prada. La «normalidad» había vuelto al país, como alguna vez, con ácido humor, comentó el poeta Martín Adán. Ese no fue el único golpe; se gestaba otro en San Marcos. El vicerrector Mauricio San Martín citó a los decanos para tomar disposiciones acerca del gobierno de la universidad. 


\section{SENADOR Y RECTOR}

La Junta de Gobierno dictó un nuevo estatuto de elecciones. Acción Popular se alió con la Democracia Cristiana; el APRA, con la Unión Nacional Odriista. Realizadas las elecciones, LAS fue nombrado senador. Antes de que Belaunde se hiciera cargo del gobierno, el 26 de julio LAS presentó su renuncia como rector de San Marcos. Lo hizo para cortar de un tajo la tesis de la incompatibilidad entre el cargo y el mandato de senador de la República, que se había empezado a esgrimir en solapado ataque.

En enero de 1965, LAS viajó a Europa. Pese a su agitada vida, se dio tiempo para escribir El pecado de Olazábal. Ese viaje también le sirvió para arribar a algunas conclusiones sobre el Congreso por la Libertad de la Cultura. Ante el maltrato inferido a su amigo Germán Arciniegas y por otros raros manejos, LAS se apartó; ya lo había hecho antes del comité de honor.

Entre los muchos viajes que realizó LAS, en 1966 hay uno que es digno de figurar en una pequeña antología. Ese año estuvo en Bogotá por breves días. Dejemos que cuente el mismo LAS: «Me alojé como de costumbre en el Hotel Continental de la avenida Jiménez de Quesada. Un día me sorprendí al darme en el hall, de manos a boca, con Jorge Luis Borges. Acompañado de su madre, una señora entera y enérgica, venía de Estados Unidos y se encaminaba a Buenos Aires con parada en Lima. Conversamos. No nos veíamos desde 1955. Estaba casi ciego; yo andaba bastante mal con mi retinitis pigmentaria. Esa noche Borges debía ir a una diligencia a la vuelta del hotel y estaba oscuro y lloviznando. La madre, que de Dios goce, creyó que nadie podría conducirlo mejor que yo. Casi me muero. Sin embargo, sacando fuerzas de la flaqueza, acepté y salí 'guiando', yo guiando, a Borges, hasta su cita y regresamos. De puro amor propio no di un traspié. Volví al hotel agotadísimo. Después, en Lima, fui el oferente de un homenaje en la Ciudad Universitaria».

En el Senado, y por iniciativa de LAS, se formó una comisión bicameral encargada de investigar el estado de la educación pública, al mismo tiempo que, juntamente con el senador Arca Parró, dedicaba a San Marcos el dinero de sus iniciativas parlamentarias. Antes había conseguido un préstamo de un millón quinientos mil dólares del Banco Interamericano de Desarrollo para fundar el Departamento de Ciencias Básicas. En lugar de agradecerle, lo señalaron como enemigo de la universidad. El año de 1965 se cerró con la publicación de El doctor Océano, un brillante estudio sobre don Pedro de Peralta Barnuevo Rocha y Benavides.

Llegó 1966. Se debía elegir rector en San Marcos y el impasse entre el cargo de senador y de rector se había solucionado. LAS tenía el campo libre para postular. Contra toda agorera predicción, y ante la alianza de parte del tercio estudiantil que había aglutinado a camaradas, amigos y algunos catedráticos, LAS salió elegido rector en primera votación. Ya no objetaron la incompatibilidad de ambos cargos; ahora el motivo era que el senador 
y futuro presidente de su Cámara iba a impedir trabajar al rector.

El año de 1967 estuvo cargado de negros nubarrones que presagiaban una peligrosa tormenta para la democracia. Ya habían sucedido la cruenta lucha contra los abigeos marxistas levantados en guerrilla y las censuras a ministros belaundistas en el Congreso, en unos casos por la torpeza de los unos y en el otro por la susceptibilidad a flor de piel de los otros. Lo cierto es que conforme transcurría el tiempo se agudizaba el enfrentamiento entre Ejecutivo y Legislativo. Todos sabían que el gobierno de Belaunde estaba herido de muerte, que un golpe militar anunciado hasta el cansancio estaba ad portas; el único que parecía ignorarlo era Belaunde. El descubrimiento de un grosero contrabando perpetrado por ciertos organismos castrenses, y el arreglo del problema de La Brea y Pariñas, que finalmente el gobierno se decidió encarar y solucionar, fueron el detonante para que un oscuro general próximo al retiro, Juan Velasco Alvarado, con un grupúsculo de coroneles de su entorno, se alzara en armas. El golpe fue entusiastamente aplaudido por toda la izquierda, con el beneplácito de Cuba y de Fidel Castro. El vicepresidente de Belaunde, el ingeniero Edgardo Seoane, irresponsable enemigo de su propio gobierno, acudió presuroso a felicitar a los golpistas.

Este nuevo cuartelazo sorprendió a LAS en pleno vuelo. Viajaba a Canadá, a dictar una conferencia en la Universidad de Laval. A su retorno al Perú, una vez más LAS tuvo que sufrir las arbitrariedades y abusos de la flamante dictadura, y la torpeza y brutalidad del general Armando Artola, ministro del Interior. Tanto su gestión como presidente del Senado, como su administración como rector de San Marcos, fueron minuciosamente escudriñadas por Inteligencia Militar, la Policía de Investigaciones y la Policía Fiscal.

En San Marcos se estaba fraguando un golpe de Estado. Decidido a cortar por lo sano y evitar mayores problemas, preparó su jubilación con un esclarecedor documento que leyó por el canal 5, al tiempo que enviaba una consulta al Consejo Universitario. Se aceptó la vacancia voluntaria a la rectoría. El pequeño complot para maltratar a LAS en la Asamblea Universitaria, manejada por los pekineses y camaradas de todos los pelajes en complicidad con algunos profesores, se frustró.

Y vino la esperada orden de detención. Fue por el nombramiento como empleado en el Congreso de un tal «señor Galván», nombre bajo el que había entrado a trabajar al Congreso Carlos Steer Lafont, que en su juventud abaleó, en la plaza San Martín, a Antonio Miró Quesada y a su esposa, crimen por el que pagó con más de veinte años de carcelería. Galván no era un empleado fantasma: trabajaba, tenía todos sus papeles en regla y no había en ese hecho agravio contra terceros ni contra el Estado. Tampoco festinación de trámites, ni nada que impidiera su contratación; como igualmente su derecho al cambio de nombre. Por otro lado, y lo más gracioso del caso, LAS había visto una sola vez en su vida a Steer, en Caracas.

En la práctica, LAS seguía siendo senador y tenía las prerrogativas de tal. No obstante, 
declaró ante el juez Carlos Hermoza Moya, quien había ordenado su detención. Al no encontrar prueba ni indicio alguno de lo que se le acusaba, Hermoza Moya decretó su libertad incondicional. El fiscal, Óscar López Aliaga, se opuso ordenando la actuación de nuevas pruebas, y pidió al juez la detención de LAS, que se internó en la clínica San Felipe. Ya por aquellos años había perdido la visión. En esos momentos el Fondo de Cultura Económica lanzó Valdelomar y la belle époque, al tiempo que publicó sus tres volúmenes de Testimonio personal. Memorias de un peruano del siglo XX. El cuarto solo aparecería en 1976.

El otro problema que preocupaba a LAS era el destino que tendría su biblioteca, con más de veinte mil volúmenes, algunos centenares de joyas bibliográficas, amén de un rico y valioso archivo. Su primera decisión fue entregarla a San Marcos, pero se decidió por la Universidad de Pensilvania, pues se aceptaron sus condiciones: que fuera mantenida como un todo; que su fondo documental, sus papeles públicos y privados estuvieran a su disposición o de quien él señalase, y que tuviera el derecho de visitar y chequear cómo se manejaba su biblioteca cada dos años.

\section{El HOMBRE DE LA TELEVISIÓN}

Mientras LAS seguía produciendo, apareció la cuarta edición de su La literatura peruana. Derrotero para una historia cultural del Perú, su Historia comparada de las literaturas americanas y el esperado cuarto volumen de su Testimonio personal, amén de Mito y realidad de González Prada.

En 1977, le otorgan el Premio Nacional de Literatura, que revistió un pequeño escándalo. Por vez primera un dictamen en minoría valía más que uno en mayoría, con lo cual le adjudicaron el galardón al poeta Emilio Adolfo Westphalen. Fue tan burda la cosa que debió intervenir el ministro de Educación —un militar correcto-, para poner las cosas en su sitio. Entre los que fraguaron ese agravio estaba un profesor sanmarquino, al cual, años antes y en peligro de muerte, LAS había enviado a que lo operaran en Estados Unidos, ya que ese tipo de cirugía cardiaca estaba en pañales en el Perú. Alguna vez recordada la infamia, LAS sentenció: "Es peligroso hacer favores en el Perú; se pagan muy caro».

Ese año le otorgan el Premio de Periodismo Bausate y Mesa. LAS publica la novela La juramentación de Dario Beltrán. También Visto y vivido en Chile; Escafandra, lupa y atalaya; Nuestras vidas son los rios. Documentos inéditos de González Prada y el Drama de las palanganas, veterano y bisoño.

Como LAS no podía estarse quieto, se le ocurrió poner en práctica una idea que tenía en mente: la Universidad Libre, usando la más moderna tecnología comunicacional: la televisión. Para ello habló con Genaro Delgado Parker, quien aceptó el proyecto. Se grabaron hasta seis programas, pero solo salió el primero. Como LAS estaba requerido, al verlo en pantalla los de la Policía de Investigaciones acudieron en manada al canal para 
llevarlo preso. Se dieron con la sorpresa de que era una grabación. Fue el primero y único programa de la Universidad Libre. Genaro no quería problemas.

Por aquel tiempo, José Jiménez Borja y Pedro Benvenutto Murrieta, amigos de LAS retomaron la iniciativa de Porras Barrenechea, y le comunicaron que iban a presentar, una vez más, su candidatura para ocupar uno de los seis sillones vacantes de la Academia Peruana de la Lengua. LAS les manifestó que aceptaba, pero que no creía que pudiesen realizar tal hazaña. Efectuada la votación el 27 de julio de 1974, solo se ocuparon cuatro de sus titulares, Martha Hildebrandt, Guillermo Lohmann Villena, Juan Ríos y Francisco Miró Quesada Cantuarias. ¡LAS no tenía los méritos suficientes para ser miembro de la docta academia! Tuvo que venir a Lima Dámaso Alonso, a fines de la década de 1970, para levantar un poco el tono de voz e imponer su autoridad moral y prestigio intelectual para que el vergonzoso veto en contra de LAS se quebrara en 1980.

Fue también el momento en que LAS se reencuentra con Basadre, dejando atrás los pequeños entredichos que por un tiempo los habían alejado. Hubo una larga y conversada comida —organizada por Mario Castro Arenas— en la que LAS y don Jorge departieron sin rencores y con la alegría juvenil de sus años sanmarquinos. Sin embargo, este acercamiento ha sido ignorado exprofesamente por algunos. Un odio enfermizo y oscuro, que sirve para sus molinos políticos, pretende seguir presentando a Basadre y a LAS como irreconciliables y jurados enemigos más allá de la tumba.

En setiembre de 1973 LAS se embarcó rumbo a España, para someterse a un chequeo en la Clínica Barraquer. Su visión era ya nula. Antes de salir de su casa le informaron que Allende había sido derrocado y se había suicidado en La Moneda. LAS sintió el golpe; conocía y apreciaba a Allende desde sus largas permanencias en Chile.

En tanto, Velasco, sus generales y sus Felipillos criollos, que querían convertir al Perú en sucursal de Cuba, habían sido defenestrados por Morales Bermúdez; los diarios de circulación nacional continuaban expropiados. El primero en caer había sido Expreso. Luego siguieron La Prensa, El Comercio, Correo, Última Hora, La Crónica. El insulto y la calumnia se derramaron, desde sus páginas, contra los enemigos de la revolución. Los sirvientes del velascato, con el correr de los años, se olvidaron de su miseria moral y resultaron defensores de la democracia; como buenos mercenarios, siempre bien rentados, hoy fungen de demócratas.

\section{LA DEMOCRACIA}

Defenestrado Velasco y estando el país soliviantado y prácticamente paralizado, Morales Bermúdez, cortó por lo sano. Conversó con los líderes de los principales partidos, en especial con el APRA — LAS fue el interlocutor válido—, y decidió llamar a una Asamblea Constituyente, para que estructurara una nueva Ley de Leyes. 
En 1978, se realizaron las elecciones para la Constituyente. LAS lanzó al mercado sus Apuntes para una biografia del APRA, su ejemplar trabajo Historia de una industria peruana - sobre la Backus y Johnston, escrita a pedido de su amigo don Ricardo Bentín-y Unanue. Ensayos polémicos; también fungió como el editor de Pizarro, el libro que Porras Barrenechea dejó inédito al momento de su partida definitiva.

Haya de la Torre, por abrumadora mayoría, fue elegido presidente de la Asamblea Constituyente; ya estaba herido de muerte. LAS trabajó como presidente interino. Sacó la nueva Constitución adelante con el apoyo de todos los partidos que conformaron esa magna asamblea, y, finalmente, encabezando una comisión, llevaron el texto para la firma final de Haya de la Torre, que no vería ya la nueva etapa democrática con un gobierno libremente elegido por el pueblo.

LAS empezó bien la década de 1980. Primero, lo incorporaron como miembro de número a la Academia Peruana de la Lengua. Segundo, en las elecciones generales de 1979, fue elegido senador por Lima. Ya en el Congreso, fue el presidente natural de la Comisión de Constitución, Derechos Humanos y Leyes Orgánicas. Desde España le llegaron buenas nuevas: la Real Academia Española de la Lengua lo contaba como uno de sus miembros.

Habiendo volteado la esquina de los ochenta años, LAS mantiene un agotador ritmo de trabajo: el que él se imponía y también el que le exigían el Senado de la República y el Partido Aprista: había sido nominado presidente de la Comisión Política. Se daba tiempo, además, para las infaltables conferencias, para escribir prólogos, para mantener sus corresponsalías y sus columnas en diarios y revistas locales y del extranjero. Pero no solo eso: salió a la televisión con un novedoso y sintonizado programa: La hora de Luis Alberto Sánchez. Todo lo cual no era impedimento para que siguiera publicando. Extrae de su archivo y da a conocer su correspondencia con Haya de la Torre. También publica Indianismo e indigenismo en la literatura peruana y empieza a publicar la estupenda serie de relatos esperpénticos: Los señores, Los burgueses, Los revoltosos y Los redentores.

Se acercaba el término de la segunda presidencia de Fernando Belaunde Terry, esta vez sin interrupción castrense. Los dos partidos con mayor opción son el APRA, con su joven líder Alan García Pérez, y la Izquierda Unida, a cuya cabeza estaba Alfonso Barrantes Lingán. LAS reúne sus discursos parlamentarios con el título de Política sin caretas y, además, exhuma un viejo relato vanguardista, un tanto signado por James Joyce, Pasajeros. P. S. N. C. Orcoma.

\section{NUESTRAS VIDAS SON LOS RÍOS...}

Realizadas las elecciones, en 1985 LAS acompaña como vicepresidente al joven presidente del Perú, Alan García Pérez. Por unanimidad es elegido presidente de la Cámara de Senadores y presidente de la Comisión Consultiva del Ministerio de Relaciones Exteriores. Se multiplica para cumplir con sus labores congresales y sus viajes: conferencias en 
las universidades de Buenos Aires, de La Plata y de Río Piedras de Puerto Rico, donde inaugura la cátedra de América Latina. Viaja a Italia, Estados Unidos, Corea, nuevamente Puerto Rico. Le recrudece una vieja dolencia y es operado de emergencia en el Hospital de las Fuerzas Policiales.

No bien repuesto de su operación, LAS prosigue incansable sus labores. Recibe el Premio Interamericano de Educación Andrés Bello. Viajes a Colombia y Holanda, donde encontró que el Grau, la que sería nave insignia de la Armada Peruana, estaba en un astillero porque no se había cumplido con pagar un pequeño adeudo. Con la eficiencia que caracterizaba todo lo que hacía, LAS gestionó el pago y, en poco tiempo, asistió a la llegada de la nave al muelle de guerra del Callao.

Las publicaciones siguen apareciendo. Libros entre la memoria, el divertimento, la biografía y la novela: Rigoletto, el sigiloso. Reimprime Perú: retrato de un país adolescente, incluyendo El Perú: nuevo retrato de un país adolescente y su Flash de un pais a punto de dejar de ser adolescente; también publica Enseñanza, descubrimiento, educación y creación. Cumpliendo una antigua tarea que se había impuesto, da término a las Obras completas de don Manuel González Prada, hace posible la publicación y prologa La música de los incas, de René y Marguerite D’Harcourt; también prologa la primera traducción al castellano —hecha por Mari Blanca Gregori- de El Perú contemporáneo, de Francisco García Calderón. La Municipalidad de Lima le rinde homenaje por sus longevos ochenta y nueve años y reedita el libro Don Ricardo Palma y Lima.

Pese a que el APRA perdió las elecciones en 1990, LAS tiene una sorprendente votación. Como cerrándose el círculo, en un acto que lo conmovió profundamente, haciéndole olvidar malos tiempos, San Marcos le otorga el rectorado emérito el 13 de mayo de 1993. LAS volvía al seno de su alma máter, al San Marcos de sus desvelos, de sus amores, de sus triunfos y de sus luchas. Era el reencuentro final y definitivo. De allí salió prácticamente a la Clínica Ricardo Palma, donde otra vez fue operado. Su tiempo estaba terminándose. LAS tenía noventa y tres años y cuatro meses cuando emprendió el viaje definitivo. Fue el 6 de febrero de 1994.

$\mathrm{Al}$ reseñar algunos datos acerca de «un peruano del siglo XX», nada menos que del más notable historiador de nuestra patria, Jorge Basadre, considero honesto dejar claro, de antemano, que mi intento es tan solo destacar algunas ideas que puedan ser valiosas para las jóvenes generaciones: peruanas y peruanos que vivirán la mayor parte de sus vidas en este apenas iniciado siglo XXI. No pretendo una semblanza del historiador. Tampoco un resumen de su vida. Menos aún un análisis de la obra escrita. Lejos se encuentra también 



\section{JORGE BASADRE}

(1903-1980)

\section{Rocío Chirinos Montalbetti}



de las presentes líneas un estudio esquemático de su producción bibliográfica. Sin embargo, dejando todo esto claro, sí que pretendo — y no es poco- compartir con el lector un acercamiento a Basadre, a su personalidad, a sus ideas, a su tenaz compromiso y pasión por la historia, a sus cualidades y virtudes.

Deseo que estas líneas sirvan de estímulo para despertar el interés por nuestro pasado, por aquello que ocupó el pensamiento y la reflexión de un peruano comprometido con el Perú. Es de esperar que, como a él, a todos nos consuma el anhelo de ver hecha realidad la promesa de la que nos hablaba: llegar a ser un país grande; un país integrado, una nación con desarrollo social; un país capaz de ofrecer calidad de vida a todos los peruanos. Y lo conseguiremos siguiendo de algún modo su ejemplo, es decir, mostrando cuán fructífero es para un país conocer su historia, enseñarla, aprenderla, escribirla en su caso y leerla en el nuestro. Solo un conocimiento profundo es capaz de despertar un amor verdadero: las humanidades nos facilitan esta capacidad humana y la historia del Perú merece que muchos jóvenes deseen estudiarla para luego transmitirla como lo hiciera este ilustre peruano a quien hoy me toca el honor de reseñar.

Las ideas que desarrollo y sobre todo el aprecio a Jorge Basadre los he recibido, en buena parte, en el seno de la familia a la que pertenezco, en las largas conversaciones con mi padre, un peruano que nos enseñó a admirar la obra del historiador y en quien él mismo se inspiró para escribir su breve Historia de la República ${ }^{92}$.

\section{AlgunOS APUnTES Biográficos}

Jorge Basadre Grohmann nace el 12 de febrero de 1903, en la histórica y heroica ciudad de Tacna, donde transcurre los primeros años de su infancia. Tacna se encontraba bajo ocupación chilena. Esas duras circunstancias constituyen el primer dato biográfico en la vida del historiador: primero en el tiempo y quizá también primero en la influencia que

92 La autora es hija de Enrique Chirinos Soto, historiador. 
tendría a lo largo de su vida. Se forja en él una especial sensibilidad hacia la patria que alimenta desde tan temprana edad su vocación esencial: el Perú. En medio de una experiencia singular y enriquecedora, la patria fue para Basadre niño, como para los niños y jóvenes que vivieron en Tacna y en Arica en esos años, una realidad que existía solo en el mundo de la esperanza y por tanto, más que una realidad, un sueño, un anhelo, una ilusión. Tacna, como Arica, pertenecían a otro Estado. Como ha señalado Basadre: «Un importante elemento de mi formación intelectual proviene de los días de mi infancia en Tacna. Es el sentimiento de la 'Patria invisible', el concepto del Perú como un símbolo. El Perú fue para mí, como para muchos, de niños, lo soñado, lo esperado, lo profundo; el nexo que unía la lealtad a los antepasados, al terruño y al hogar que invasores extraños y abusivos quisieron cortar, con el conocimiento vago de una historia reiteradamente luminosa, a pesar de numerosas caídas y la fe en un futuro de liberación $»^{93}$.

En 1909 fallece su padre y tres años más tarde la familia se traslada a Lima. ¿Qué era Lima en esas épocas? Quizá algunos tengamos presente una conocida expresión que Abraham Valdelomar hiciera correr en esos años: «El Perú es Lima, Lima es el jirón de la Unión, y el jirón de la Unión es el Palais Concert». Lima, en efecto, era para una familia que llegaba de provincia, la capital distante y lejana de los problemas y necesidades del resto del país. Basadre estudia en el Colegio Alemán. El último año de secundaria lo realiza en el tradicional Colegio de Nuestra Señora de Guadalupe. Más adelante, siendo ministro de Educación, firmará un decreto, por el cual el Colegio de Guadalupe recibirá, en atención a su antigüedad y trayectoria, el título de «Primer Colegio Nacional del Perú».

Basadre ingresa a los 16 años, "pobre, huérfano y provinciano" ", a la Universidad Mayor de San Marcos, al primer año de Letras. Todo esto, vivencias, estudios, contacto con compañeros y profesores, no va a hacer sino contribuir decididamente en la formación de su personalidad. Será Basadre un joven disciplinado y estudioso. Después de prestar algunos servicios como auxiliar en la Biblioteca Nacional y también como redactor del Boletín Bibliográfico de la Biblioteca de San Marcos, es nombrado catedrático de Historia del Perú en esa misma universidad en 1928. Tiene oportunidad por esos años de volver a Tacna para integrar parte de la Delegación Peruana de Límites, enviada ante la Comisión Plebiscitaria de Tacna y Arica. Poco después es llamado para desempeñar el cargo de director de la Biblioteca Central de San Marcos. Adquiere los grados de doctor en Letras y en Jurisprudencia, y el título de abogado.

\section{El MÁS DESTACADO HISTORIADOR DE NUESTRA REPÚbliCA}

Su obra escrita es de una magnitud abrumadora en libros, folletos y artículos. Bien se

93 Cfr. Basadre 1959: 91.

94 Cfr. Basadre 1975: 121. 
puede afirmar que Basadre es, sin duda, el más destacado historiador de nuestra República. Contrariamente a lo que se podría pensar, no transcurrió su vida en circunstancias propicias para las tareas de investigar, escribir y publicar. Debió alternar su dedicación a la historia con otras obligaciones como la cátedra, el trabajo en la Biblioteca de San Marcos y en la Biblioteca Nacional, y otras tareas públicas y administrativas que no le faltaron. Basadre tendrá que buscar espacios para dar cauce a la pasión de su vida —la historia—y a su arraigada vocación de escritor.

De 1928 a 1931 se publican tres obras imponentes, llenas de vigor y perspectiva histórica: por un lado, La iniciación de la República (1928) y La multitud, la ciudad y el campo en la historia del Perú (1929), que fue su discurso de orden, en la apertura del año académico de 1929, como joven catedrático de San Marcos. Tenía entonces 26 años. Y en 1931, publicó Perú: problema y posibilidad. Ensayo de una sintesis de la evolución histórica, uno de los libros de mayor resonancia en el pensamiento peruano, en el que el joven Basadre da muestras de una extraordinaria capacidad de análisis y de una visión integradora de la historia. En medio de una de las peores crisis de nuestra vida republicana, las páginas de Perú: problema y posibilidad invitan a pensar y a reflexionar. Basadre presenta la coyuntura oscura e incierta con una tesis de fondo: el Perú ciertamente revela un "problema», pero a la vez hay que atreverse a una solución y presentarlo como una "posibilidad». En palabras de Pablo Macera, «más allá de la edad de su autor, es un libro magistral, con todas las calidades de autodisciplina y de ponderación que caracterizaron al maestro en todas sus obras posteriores y sobre todo en su propio estilo de vivir»»' ${ }^{95}$. libro se agotó. Una nueva reimpresión se realizará recién en 1978. Basadre quiso mantener intacto el espíritu juvenil de la primera edición y completar con anexos los diversos capítulos de la obra, después de 47 años de haberla publicado.

Un segundo momento en la producción escrita del historiador transcurre de 1935 a 1946, después de haber tomado contacto con las escuelas bibliográficas europeas, más en particular con la escuela alemana sobre historia del derecho y con la española sobre historia institucional. Basadre publica Las fuentes para la historia del Derecho peruano, su tesis doctoral, en 1935, y la Historia del Derecho peruano, en 1937, que recoge la cátedra que dictó en San Marcos. La primera edición de lo que será la obra más importante aparece también en esta época: la Historia de la República en 1939, cuya segunda edición, revisada y aumentada, se publicará al año siguiente.

A partir de 1943, en el gobierno de Manuel Prado, Jorge Basadre acepta la difícil tarea de dirigir y rehacer la Biblioteca Nacional, que había quedado destruida como consecuencia de un incendio. Como parte de su labor de reconstrucción y reorganización de la biblioteca, fundó dos publicaciones, la revista Fénix y el Anuario Bibliográfico Peruano.

95 Cfr. Macera 1994: 10. 
Dos años más tarde es nombrado ministro de Educación Pública del gobierno constitucional y democrático de José Luis Bustamante y Rivero. A esos años corresponden $\mathrm{La}$ promesa de la vida peruana (1943); Meditaciones sobre el destino histórico del Perú (1945), y la tercera edición de la Historia de la República, que aparece en 1946 y que incluye la primera década del siglo XX. Tres años más tarde, nuevamente corregida y aumentada, sale a la luz la cuarta edición.

A partir de 1958, Basadre puede dedicarse, por entero, sin otros compromisos, sin otras obligaciones, sin otras distracciones, a pulir la obra de su vida: la Historia de la República, que en 1967 alcanza en su sexta edición los 16 volúmenes. Se puede afirmar que esta constituye el resultado maduro y profundo de cuarenta años de investigación, de creación y recreación, de corrección y de ampliación. Su contribución a la cultura y al pensamiento peruanos es tal que permite referirnos a Basadre sin temor a exageración como «al investigador ejemplar de nuestra historia, de nuestras letras y de nuestra cultura; al historiador por excelencia de la República; al bibliógrafo más calificado del Perú y de América que ha dado nivel científico a la disciplina con sus investigaciones en este campo» ${ }^{96}$. Así, dedicado a la investigación, inmerso en la meditación de los temas de nuestra historia, realista en el alcance de nuestra tradición y crítico en el análisis de sus causas humanas, Basadre fallece en Lima, el 29 de junio de 1980, a los 77 años de edad. La avenida Orrantia, del limeño distrito de San Isidro, donde quedaba su casa, recibe poco después su actual y merecido nombre: avenida Jorge Basadre.

\section{Apasionado de la historia y apasionado del Perú}

¿Qué cualidades personales encontramos en este "peruano del siglo XX»? ¿Cuál podría ser su legado a las generaciones que lo suceden? Basadre fue, en primer lugar, un apasionado del Perú y, por ende, de la historia del Perú. Su pasión no es irracional, sino llena de disciplina, iluminada con la ciencia y la paciencia de todo intelectual serio, movilizada por la finalidad que le da el amor a su patria. Basadre muestra el talento de un apasionamiento que no ciega y mantiene en todo momento el equilibrio que le brinda su búsqueda desinteresada por la verdad. No pierde el equilibrio, por ejemplo, cuando tiene que encontrar fallos o imperfecciones en el admirable gobierno de Piérola. No lo pierde tampoco cuando, en el trance de la severidad, debe reconocer méritos o aspectos positivos en la persona de Leguía y en su larga gestión gubernativa. Desarrolla la aptitud noble de remontarse por encima de las pasiones, de las inclinaciones políticas o de sus antagonismos, para explicarnos la realidad sin manipularla, sin esconderla, sin justificarla con motivos que no existen.

Sus virtudes son acaso el reverso de los defectos nacionales o, con expresión quizá positiva, el compendio de los dones o atributos que nos faltan. Prolijo, investigador incan-

96 Cfr. Puccinelli 1994: 25. 
sable, modesto y humilde buscador de la verdad, Basadre se forma en el duro hábito de la disciplina y del estudio, tan lejanos de la improvisación y del lucimiento. Deja una obra acabada. Nos entrega una visión no exhaustiva pero sí completa y, casi pudiera decirse que cabal, de la República, escrita en condiciones de carencia de medios, inimaginables para un historiador de su talla: sin equipo, sin auxiliares, sin apenas bibliotecas y archivos.

Paciente, tenaz, minucioso, reiterativo, terriblemente serio, austero y organizado. Basadre reflexiona, mientras otros acaso nunca resisten a la tentación de la ligereza. Él entiende su trabajo no como ocasión de lucro o como programa de goce sino como tarea orientada al cumplimiento de un deber: el del ejercicio de una meditación incesante sobre el Perú, sobre su historia y su futuro.

Basadre actúa, piensa y escribe con serenidad. Serenidad que, en momentos difíciles, puede ser, a juicio de algunos, manifestación de espíritu dubitativo o vacilante y que, por el contrario, no es más que ponderación o compromiso con la verdad, o al menos con la búsqueda de la verdad. Basadre se muestra independiente, es decir, no ligado ni deudor de las circunstancias o de los favores políticos. No ejerce poder por la fuerza de su apellido, ni de su posición social, que no le interesan: «En ningún momento — manifiesta—, la Historia de la República ha tenido ni ha buscado la protección oficial. Su difusión proviene exclusivamente del favor de sus lectores. Tampoco ha recibido subvenciones, primas, auxilios o favores de personas o familias importantes o desconocidas. A nadie debe y a nadie odia; a nadie teme y a nadie adula» ${ }^{97}$.

Basadre es uno de los grandes hombres del siglo XX y de los grandes hombres del Perú: su influencia poderosa es el resultado de su inteligencia y de su voluntad, de su esfuerzo por el estudio y de su amor a la patria. Es toda la persona que se expresa con la herramienta de una heroica y denodada capacidad de trabajo.

¿Cuál podría ser su virtud más connotada? ¿Serenidad, juicio, equilibrio, sobriedad, disciplina, desprendimiento, honradez, dedicación, independencia? Quizá podríamos afirmar, respetando la opinión de expertos conocedores de su vida y obra, que la lectura de Basadre transmite con fuerza un emocionado, reverente y transido amor al Perú. Y a esta virtud la llamamos patriotismo. Los 16 volúmenes de la Historia de la República, como resultado final o punto de llegada de toda su producción bibliográfica, constituyen una indagación de los motivos para amar al Perú, para amar su esencia y su identidad.

Sus reflexiones autobiográficas son un testimonio más acerca de lo que él consideró verdaderamente relevante en su existencia: «A la larga, lo que importa, en la vida y en la obra, es ser uno leal consigo mismo, proceder de acuerdo con el fondo 'insobornable' que todos llevamos dentro. [...] De experiencias, lecturas y reflexiones saqué, en desorden, otras normas: tratar de no obrar apasionadamente, que es una forma de confundirse;

97 Cfr. Basadre 1949: 14. 
mantener la independencia personal ya que 'más preciosa es la libertad que la dádiva porque se pierde'; abrir los ojos con tiempo; percibir cuando se cayó en desaciertos; no insistir en la necedad y seguir al clásico en su frase 'ni la promesa inconsiderada ni la resolución errada conducen obligación'; dedicarse al estudio por el goce que él genera en virtud de una necesidad esencial y nada más que eso; hacer de los asuntos que se investiga una cosa que interesa tanto como la existencia propia; vivir en permanente estado de alerta intelectual con un sentimiento radical de las propias imperfecciones; aprender a morar con uno mismo; ocuparse de los trabajos propios y no tanto de criticar el de los demás; emprender lo fácil como dificultoso y lo dificultoso como fácil; no atemorizarse ante la tentativa vasta e ir a ella sin inconstancia ni engaño porque, según se lee en La Celestina, las obras hacen linajes; no imitar a quienes comienzan y nunca acaban y poner atención a que, con sus defectos inevitables, salgan bien las cosas; tratar de evitar en la obra y en la vida la intención malévola; procurar ir, en desafío al paso de los años, a la renovación perenne en los conocimientos y en las ideas; rumiar y rumiar siempre lo que se piensa y lo que se escribe; sentir y seguir sintiendo que sin la desinteresada curiosidad intelectual no se puede vivir y que la ausencia de ella es una forma de muerte; buscar el modo de alejarse sistemáticamente tanto de la vanidad como de la actitud humillante, para quedar en una modestia orgullosa. Y lo más importante de todo: buscar y tratar de mantener la paz interior como algo de mayor valía que cualquiera de los títulos mundanos, es decir, una conciencia tranquila»" ${ }^{98}$.

\section{Una visión analítica del Perú}

Basadre desarrolla un talento eminentemente analítico, que no se agota en sí mismo. Por eso puede llegar, como de hecho llega, a realizar síntesis brillantes. Y es que solamente puede ofrecer una síntesis del fenómeno histórico quien tiene la capacidad analítica para captarlo y desintegrarlo en sus variados y distintos componentes. Basadre muestra un estilo contundente, un análisis profundo y un afán realista de compromiso con el Perú: «fui terco al hurgar desde los 16 años en el campo del pasado nacional»".

A la vez, Basadre es crítico y se revela como un historiador que ejerce una insólita censura sobre los hechos. Entra al fondo de la herida para luego proceder a realizar un diagnóstico esperanzador como el especialista entendido en las causas de los males. Pongamos un ejemplo: ¿cómo ve Basadre al Perú? Como «un país de demasiadas oportunidades perdidas, de riquezas muchas veces malgastadas atolondradamente, de grandes esperanzas súbitas y de largos silencios, de obras inconclusas, de aclamaciones y dicterios, de exalta-

98 Cfr. Basadre 1981: 638-639.

99 Cfr. Basadre 1999: 1. 
ciones desaforadas y rápidos olvidos. País dulce y cruel, de cumbres y de abismos» ${ }^{100}$. A una síntesis dura, sigue una visión esperanzadora: «Aunque es tan rico y tan complejo el pasado del Perú, lo que importa sobre todo no es lo que fuimos sino lo que si, venciendo la inextinguible capacidad nacional para buscar la agonía espiritual con el yaraví de la autoflagelación y de la autonegación o para soplar en el pututo del encono, pudiéramos ser, si de veras lo quisiéramos» ${ }^{101}$.

\section{Historiador SERIO}

Los historiadores sabemos, por experiencia y en connaturalidad con nuestra profesión, que la historia no se inventa. Está en las fuentes, en los papeles, y estos se hallan en los restos arqueológicos, en los monumentos, en los archivos, en las hemerotecas, en las bibliotecas. Además, como es lógico, los datos no se encuentran si no se buscan.

Basadre es historiador comprometido con la investigación y con el rigor, con la búsqueda de la verdad y con la reflexión; no se queda en los datos, abordar los grandes problemas que acompañan a nuestra República. Sus escritos constituyen un permanente enlazamiento de las consecuencias del juicio al que se llega tras una búsqueda exhaustiva en los hechos. Son nuestros problemas los que de verdad le preocupan.

Basadre es un historiador serio. Su interés es dar una visión de nuestra historia muy documentada. Quiere en todo momento hacer una honrada reconstrucción de nuestro pasado, y se exige en tomar en consideración la mayor cantidad de datos fiables que puede encontrar. Muestra preocupación por conocer lo más reciente de la producción historiográfica y evita caer en los dos extremos del péndulo: la rigidez y la inexactitud.

Basadre es reflexivo: su pensamiento es profundo, cultivado por la meditación y la indagación cuidadosa. Profundizar en la investigación es también reflexionar. Su tema es el Perú, su pasión es el Perú y su investigación va dirigida a esta cuestión apasionante.

Basadre ha encarnado una técnica del trabajo intelectual, un método para reunir, clasificar, valorar y utilizar los materiales de información, un criterio para distinguir entre lo auténtico y lo fundamental de lo simulado o improvisado en la vida o en los libros. La historia de Basadre, lejos de quedarse en un acopio de datos, es un intento constante por desentrañar, detrás de los hechos y de las cifras, las conexiones entre estas y aquellos para lograr dar sentido a la masa informativa. Basadre no quiere reducir la historia a una exposición de hechos. La historia reducida a hechos necesita un sentido, porque el sentido refleja la realidad profundamente humana, por encima de la actividad meramente biológica de la naturaleza y de la meramente repetitiva de la técnica. El sentido responde a unas preguntas que solo un ser libre, racional y responsable de sus actos es capaz de ha-

100 Cfr. Basadre 1979.

101 Cfr. Basadre 1999: 1. 
cerse: ¿para qué? y ¿por qué? Por eso, el historiador siempre busca ir más allá. Basadre así lo entiende y ve que la historia permite sacar a los hombres de sí mismos para colocarlos en una consciente relación con el mundo, en la posibilidad de ser actores responsables de un proceso que comenzó antes de que ellos nacieran y continuará después de su muerte. Así, el conocimiento de la historia y la acción de cada peruano están íntimamente relacionados: un mal saber histórico precondiciona el quehacer histórico mismo.

En esto, Basadre supera las orientaciones que algunos quisieron dar a la ciencia histórica a mediados del siglo XX, al colocar por encima de todo a la pura teoría metodológica, a la consideración cuantitativa de los datos como ley científica para la interpretación de los hechos. Fernand Braudel, en defensa de una investigación histórica que no se pierda en datos y cifras, señalaba: «No son solo los métodos o los medios los que cuentan, sino los resultados y, más aún, la interpretación, la puesta en obra de tales resultados; en una palabra, aquello con lo cual en caso de necesidad es posible corregir más de un error debido al método» ${ }^{102}$. Basadre se coloca a la altura de las grandes corrientes historiográficas del siglo XX.

En consecuencia, encontramos en Basadre «un pensamiento vivo, un pensamiento en constante modificación. Pocos de sus textos escaparon a su autocrítica, a su reelaboración permanente, renovando siempre sus páginas añejas a la luz de nuevas lecturas y meditaciones [...] En suma, se trata de un pensamiento que no acepta ideas destinadas a permanecer inmutables» ${ }^{103}$. Esta autocorrección ejercitada cuantas veces sea necesaria, lejos de desconcertar, es una muestra más de su rigor. Como historiador, le importa hacer ciencia, no dejar sentadas opiniones. Quiere acercarse a la verdad de cuestiones profundas que a todo peruano interpelan. Intenta reconstruir nuestro pasado, las más de las veces doloroso: trata de acercarse lo más posible a la verdad; es honrado consigo mismo y con los peruanos. Como escribió Enrique Chirinos Soto, mi padre, «a todos los peruanos, y señaladamente a las generaciones posteriores a la suya [...] sin pesadumbre y, al mismo tiempo, sin fatuidad, nos ha señalado la difícil tarea y la bella esperanza del Perú. Nos ha predicado incesantemente que la patria es, a no dudarlo, un problema; pero que es también, por fortuna, una posibilidad. Es un quehacer para hoy, por lo tanto, recio y emocionante, que sería superfluo si no hubiese problemas, y que sería inútil si los problemas no tuviesen solución. Basadre se ha internado en el pasado porque le interesa, vivamente, el provenir» ${ }^{104}$.

\section{La indagación ante la PRegunta metafísica: ¿QUÉ es el Perú?}

Muchas veces la vida nos lleva a un ritmo vertiginoso. Vivimos sin detenernos. Avanza-

102 Cfr. Braudel 1960: 493-523.

103 Cfr. Yepes del Castillo 2004: 6.

104 Cfr. Chirinos Soto 1991: 316. 
mos sin saber hacia dónde nos dirigimos. Conocemos nuestro presente, pero no tenemos la misma conciencia acerca de nuestro origen y de nuestro destino. Este tiene que ver con aquel. Dentro de las cuestiones que toda persona debe resolver a lo largo de su vida están las de su identidad, las de su destino, las de su misión. ¿Quién soy? ¿De dónde vengo? ¿Dónde he nacido? ¿Quiénes son mis padres? ¿A qué lugar pertenezco? ¿Cuál es mi patria? ¿Cuándo se creó? ¿Cuál es su destino?

Basadre muestra quizá sus mayores esfuerzos como historiador en el intento de dar respuestas profundas a algunas de estas cuestiones que son fundamentales en la existencia de toda persona o, para nuestro caso, de todo peruano.

¿Qué es el Perú? Ante esta difícil pregunta, responde con claridad de lenguaje y con la certeza que le brindan los hechos y datos tan largamente meditados: «El Perú existe como totalidad en el espacio y como continuidad en el tiempo» ${ }^{105}$. Sigo en los siguientes párrafos las ideas desarrolladas por Basadre en Meditaciones sobre el destino histórico del Perú y mantenidas a lo largo de toda su obra.

¿Cómo entender estas palabras? ¿Cuándo empieza a existir el Perú? Cuando en 1821 fue proclamada nuestra Independencia el Perú ya existía. José de San Martín es el fundador de la Independencia. Simón Bolívar, el de la República. El Perú mismo, como geografía y como historia, como territorio y como espíritu, es sin embargo anterior respecto de su propia estructura republicana. Dice Basadre: «Cuando se trata de averiguar acerca del nacimiento de la conciencia nacional peruana, la respuesta solo puede darse después de una pesquisa. Pasado muchísimo tiempo después de la formación geológica del territorio, solo algunos siglos después del desembarco de Pizarro y algún tiempo antes de la encendida escena en la Plaza de Armas, habrá que buscar el nacimiento de la conciencia nacional peruana, aún no lo suficientemente madurada» ${ }^{106}$.

Basadre señala dos fechas que nos acercan con bastante exactitud al nacimiento de nuestra patria. Son las de 1609, año en que se editan Los comentarios reales, del Inca Garcilaso, el cantar de gesta de nuestra nacionalidad; y 1791, año de la primera edición del Mercurio Peruano, donde figurará la palabra "patria» en su sentido exacto y propio. 1609 y 1791 «señalan, pues, los dos documentos que al Perú naciente definen literalmente». En efecto, hay que remontar la partida de nacimiento del Perú probablemente hasta Los comentarios reales, del mismo modo que Grecia se lo debe a las obras homéricas; y esa individualidad histórica, que carece todavía de constitución política, es la que, a las alturas de 1821, decide romper los lazos que la ataban, para iniciar su vida independiente.

Pero, como acabamos de ver, Basadre también afirma que el Perú es totalidad en el espacio y en el tiempo. ¿Qué quiere decir totalidad en el espacio? Su respuesta reza:

105 Cfr. Basadre 1947: 79.

106 Cfr. Basadre 1947: 105. 
«Armoniosa coexistencia de la loma y la puna, del cóndor y del alcatraz, de la quinua y el algodón, el ichu y el amancay, de la papa y el algarrobo, del mate ayacuchano y el sombrero de Catacaos, de la chicha y el pisco, de la natilla y el picante, de las piedras del Cusco, la cortesanía de Lima y las revoluciones de Tacna heroica en el cautiverio aunque olvidada después de la reincorporación ${ }^{107}$. Y ¿continuidad en el tiempo? Con esta expresión, Basadre entiende el Perú como «un largo acontecer histórico donde lo inca vale solo en la medida en que supervive dentro de la peruanidad y en tanto y en cuanto sirve a la peruanidad; y donde lo hispano vale únicamente si es que se ha adaptado o se ha enraizado en la peruanidad ${ }^{108}$.

Al Perú, en el pensamiento de Basadre, le ocurre lo que a otras muchas naciones: no tenemos unidad de raza, ni de idioma, ni de sangre, ni de geografía; todo divide y todo desune. Pero somos una nación. Los peruanos, de norte a sur, de la costa, de la sierra y de la selva, nos sabemos y nos sentimos peruanos. «QQué tienen de común en 1824 un labriego de Piura y un labriego del Cusco, por ejemplo? Muy poco, evidentemente. Pero ambos y otros como ellos y sus antepasados vivían dentro del mismo ámbito políticoadministrativo y no únicamente desde el siglo XVI sino desde muchos siglos antes de los incas. Este molde impalpable influyó, de una manera u otra, sobre su niñez, su juventud, su adolescencia, su ancianidad y sobre las de sus familiares. ¡Cuántos son los pueblos europeos, asiáticos, africanos que carecen de esa larga continuidad en su destino histórico!! ${ }^{109}$.

\section{La Promesa del Perú: la fe en el futuro}

Cada 28 de julio debe ser para los peruanos no solamente coyuntura de júbilo legítimo, sino también severa ocasión de examen y tarea para la reflexión. ¿¿Somos lo que deberíamos ser? ¿Hemos alcanzado ya esas cualidades de nación libre, soberana, desarrollada, socialmente integrada, justa? ¿Estamos contentos con nuestro país?

El Perú se independizó, sí, el 28 de julio de 1821, pero ¿para qué? ¿Para qué se fundó la República? Para cumplir la promesa que en ella se simbolizó: para gobernarnos a nosotros mismos con plena autonomía. Para ser mejores, para elevar los niveles de vida de todos los peruanos, para lograr un proyecto de nación libre y soberana. A ese propósito, a esa esperanza, a esa ilusión, Jorge Basadre les ha dado el nombre de «la promesa de la vida peruana».

La promesa de la vida peruana no se ha colmado en la hora más gloriosa, pero tampoco ha sido definitivamente desahuciada, ni siquiera en la hora más sombría. Tal es la razón de nuestra esperanza: esperanza real, histórica y fundada. Una nación es un proyecto de vida común. El Perú debe ser también para los peruanos ese proyecto de vida común que

107 Cfr. Basadre 1947: 95.

108 Cfr. Basadre 1947: 95.

109 Cfr. Basadre 1983, vol. I: IX-X. 
Basadre quiso que sea. Una voluntad de vivir para hacer cosas grandes. Un propósito para forjar esa nación a la que todos tenemos derecho.

\section{¿Por Qué Debemos leEr a Basadre? Lección de PeRUanidad}

La historia despierta pasiones; enseña lecciones; abre horizontes; amplía perspectivas; responde a cuestionamientos. Basadre, como los clásicos, entiende que la historia es pedagogía. Es maestra de la vida. Sus lecciones son vivas, aplicables, concretas. De la lectura de Basadre todos los peruanos salimos beneficiados, enriquecidos. El personaje más importante de la historia del Perú, como él mismo señala, es el Perú.

Hoy el Perú tiene, con seguridad, problemas cuantitativa y cualitativamente diversos, a los que tenía en el siglo XIX o en el XX, pero sigue siendo para todos los peruanos "problema y posibilidad». Nos preocupa la situación de nuestro país y nos preocupa acertar en el camino para salir adelante como nación, como pueblo, como patria. No queremos que nuestra historia continúe siendo de oportunidades perdidas y de posibilidades no aprovechadas, sino de oportunidades aprovechadas y posibilidades ganadas. Pero hay que aprender la lección.

Lección de esperanza en la peruanidad. Hay un horizonte esperanzador, aunque todavía tengamos un largo camino que recorrer. El Perú es, efectivamente, un país con inmensas posibilidades de crecimiento, de desarrollo, de progreso, de mejora: son las estrategias, los planes de acción concretos en los diversos campos —educación, en primer lugar, salud, economía, industria, turismo y cultura - los que deben consolidar esas esperanzas.

Lección de fe en la peruanidad. Es prioritario recuperar la autoestima nacional y el conocimiento de nuestra riquísima historia puede ser la mejor herramienta. Los peruanos debemos crecer en la confianza en nuestras capacidades porque sabemos que nuestros antepasados fueron autores de culturas florecientes. El principal recurso de un país lo constituyen sus personas y, por eso, el desarrollo que queremos alcanzar debe tener como punto de partida la educación no solo en el ámbito intelectual sino también en el de las virtudes, que producen la real transformación de cada peruano.

Lección de valentía. Los peruanos debemos aprender a no dejarnos vencer, a luchar por un ideal, por un Perú mejor y más justo. Es esta una batalla de esfuerzos, sacrificios y vencimientos. «El mal — señala Basadre— no está, pues, en el Perú en sí. Visto con una perspectiva de siglos, mantiene una línea continua de altitud en el continente, ha llegado a producir el heroísmo como la santidad y sus caídas abarcan, comparativamente, un breve lapso. Mirando el desarrollo posible del futuro, las perspectivas son vastísimas. Aceptemos que todo lo que ocurrió aquí hasta ahora es prehistoria. El mal verdadero, el peligro terrible, se halla en cambio por el otro lado: en el empequeñecimiento espiritual ${ }^{110}$. 
Lección de solidaridad entre todos los que constituimos la peruanidad. Con una autoridad moral avalada por su inobjetable trayectoria, Basadre nos enseña que «solo el esfuerzo individual y colectivo podrá conseguir que el Perú deje de ser una «bella promesa no cumplida». Hay que soñar con «una fórmula de construcción nacional y social para un Perú de más altos niveles de vida, con un Estado técnico, un país progresista, un pueblo atendido, cuidado, entusiasta, creador ${ }^{111}$. Debemos desarrollar más esta solidaridad: solidaridad económica para que desaparezcan las diferencias sociales tan pronunciadas de nuestra patria; solidaridad en las verdaderas convicciones, para que haya no solo tolerancia sino búsqueda sincera de valores que nos unen; solidaridad como manifestación del amor al prójimo, que es una lección que debemos agradecer a la fe cristiana, difundida en nuestra tierra por el pueblo español.

Para terminar, pienso que debemos reconocer y agradecer a Dios y al Perú la existencia de Jorge Basadre, como peruano y como historiador de nuestra patria. Su aportación al pensamiento político y a la cultura del siglo XX nos refuerza en la convicción de que en el Perú, sea cual fuere la circunstancia histórica que atraviese, siempre habrá una promesa y una esperanza por cumplir. Y esta convicción la encontramos en la historia de nuestra patria, estudiada y brillantemente en su obra, que nos afianza en otra idea que llena a todo peruano de optimismo: el Perú es y será siempre una gran nación.

\section{BibLIOGRAFÍA}

BASADRE, Jorge (1947). Meditaciones sobre el destino histórico del Perú. Lima: Ediciones Huascarán.

(1949). Historia de la República del Perú, cuarta edición nuevamente revisada y aumentada. Lima: Editorial Cultura Antártica, tomo I, nota preliminar en la cuarta edición. (1959). Infancia en Tacna. Lima: Talleres Gráficos Villanueva.

(1966). Perú vivo. Lima: Editorial Mejía Baca.

(1975). La vida y la historia. Ensayos sobre personas, lugares y problemas. Lima: Fondo del Libro del Banco Industrial del Perú.

(1979). Discurso agradeciendo la imposición de la Orden del Sol. Lima.

(1981). La vida y la historia. Ensayos sobre personas, lugares y problemas, segunda edición revisada y aumentada por el autor. Lima: Industrial Gráfica.

(1999). Mensaje al Perú. Lima: Editorial Universitaria.

BRAUDEL, Fernand (1960). La démographie et les dimensions des sciencies de l'homme. París: Annales E. S. C., nro. 3, pp. 493-523.

CHIRINOS SOTO, Enrique (1991). Historia de la República. Lima: A. Ch. Editores, cuarta edición, tomo II. 
MACERA, Pablo (1994). Presentación de la obra del Dr. Jorge Basadre. Perú: problema y posibilidad. Lima: Fundación Manuel J. Bustamante de la Fuente.

PUCCINELLI, Jorge (1994). Presentación de la obra del Dr. Jorge Basadre. Perú: problema y posibilidad. Lima: Fundación Manuel J. Bustamante de la Fuente.

YEPES DEL CASTILLO, Ernesto (2004). Memoria y destino del Perú. Jorge Basadre: textos esenciales. Lima: Fondo Editorial del Congreso de la República del Perú.

«...yo soy un peruano que orgullosamente, como un demonio feliz habla en cristiano y en indio, en español y en quechua».

José María Arguedas. 



\section{José María Arguedas \\ (1911-1969) \\ Santiago Pedraglio}



El breve texto de José María Arguedas «No soy un aculturado...», leído por él en Lima, en octubre de 1968 al recibir el Premio Garcilaso de la Vega, y más tarde publicado a su solicitud a modo de prefacio de El zorro de arriba y el zorro de abajo, su novela póstuma, es una síntesis lúcida y emocionada del plan que se trazó como escritor.

Arguedas se define allí como «un individuo quechua moderno». Esta autopercepción es decisiva. Tres factores esenciales —el reconocimiento de su individualidad moderna, la certeza del valor de su cultura y su vocación transformadora— serán el núcleo activo de su decisión de emprender la difusión del mundo quechua entre lectores de otros mundos. Ciertamente, Arguedas recuerda que ya desde su juventud no tuvo más ambición que «[...] volcar en la corriente de la sabiduría y el arte del Perú criollo el caudal del arte y la sabiduría de un pueblo al que se consideraba degenerado, debilitado o 'extraño' e 'impenetrable', pero que, en realidad, no era sino lo que llega a ser un gran pueblo oprimido por el desprecio social, la dominación política y la explotación económica en el propio suelo donde realizó hazañas por las que la historia lo consideró como un gran pueblo» ${ }^{112}$.

Así pues, su propósito explícito es vasto, pero también muy preciso: volcar en el Perú criollo el arte y la sabiduría del pueblo quechua. No habla de disolverlos —ese arte y esa sabiduría - en un magma mayor, sino más bien de lo que por estos tiempos se ha dado en llamar «ponerlos en valor». De desvelarlos, se podría decir, de modo tal que aquellos a quienes les tocó formarse en una cultura que se presenta como superior (el Perú criollo) tengan la oportunidad de conocerlos y, en su caso, apreciarlos más allá de las grandezas del pasado remoto.

Iluminar y transmitir el arte y la sabiduría quechuas para abrir el cerco secuestrador instalado en torno a esta cultura, tal vez teniendo en mente incluso impedir su desaparición. Pero hacerlo procurando el diálogo entre culturas enfrentadas, que tienen no obstante un sinnúmero de puntos de contacto, empezando por su pertenencia a un país al que teóricamente pertenecen como iguales. Tarea inacabada en su momento y acaso inacabable, más ardua aún tratándose de una propuesta que, a diferencia del indigenismo a ultranza, no es excluyente en modo alguno, por más cargada que esté de tensión

112 Cfr. Arguedas 1983 [1971]: 9. 
y conflicto, de victorias y frustraciones.

El punto más importante y ambicioso de este plan de escritor se concentra en una afirmación comprometedora: «[...] intenté convertir en lenguaje escrito lo que era como individuo: un vínculo vivo, fuerte, capaz de universalizarse, de la gran nación cercada y la parte generosa, humana, de los opresores ${ }^{113}$. Las palabras claves de esta aseveración fundamental son «vínculo» y «universalizarse». Arguedas era consciente de la fortaleza de su relación con las dos culturas y de la capacidad de universalización concentrada en ese vínculo.

El itinerario creativo propuesto por Arguedas tiene su corolario y su origen en la convicción de que, después de siglos de dominación, «en técnica nos superarán y dominarán, no sabemos hasta qué tiempos, pero en arte podemos ya obligarlos a que aprendan de nosotros y lo podemos hacer incluso sin movernos de aquí mismo» ${ }^{114}$. Este arte es comprendido por Arguedas no solo como el espacio privilegiado de intercambios simbólicos dentro de la cultura del hombre quechua, sino, hoy por hoy, como la manifestación más elevada de esa cultura. Implícitamente, es la afirmación de que si bien la tecnología no pudo seguir desarrollándose, el arte, un valor que también la cultura occidental considera fundamental ${ }^{115}$, sí logró continuidad.

\section{Chimbote: Un EnCUentro CASUAL}

Llegué a vivir al puerto de Chimbote a mediados de 1970, semanas después del terremoto que devastó varias ciudades de la región y solo unos pocos años después de que Arguedas trabajara ahí recopilando material para lo que sería su novela más avezada.

Leí El zorro de arriba y el zorro de abajo, la primera vez, en ese puerto. Parte del atractivo de la lectura fue para mí identificar los lugares, los olores, los personajes. Más tarde la he leído de distintos modos: linealmente, siguiendo la narración impuesta por el autor; obviando los diarios y concentrándome exclusivamente en la narración literaria; o al revés: solo los diarios, haciendo esfuerzos para olvidar la historia. Entre una y otra lectura hubo a veces muchos años de intervalo; quizá por eso, y por todo lo que los años traen consigo, me han suscitado sensaciones y convicciones muy diferentes.

En Chimbote, a menudo me topé con el Loco Moncada, que caminaba con su red, hablando solo o conversando con los curiosos que le pasaban la voz. Conocí a los dirigentes de izquierda que en ese entonces desplazaron al APRA del sindicato de pescadores.

\footnotetext{
113 Cfr. Arguedas 1983 [1971]: 10.

114 Cfr. Arguedas 1983 [1971]: 11.
}

115 No es casual que Mario Vargas Llosa señale que «[...] el arte tiene una función central que cumplir dentro de la cultura de una época, es un centro neurálgico de la vida espiritual de una comunidad, una fuente de solaz y de goce, de enseñanzas para depurar las imperfecciones de que está hecha la rutina cotidiana y un guía que constantemente señala unas formas ideales de ser, de amar, de vivir y hasta de morir». Cfr. Vargas Llosa 2008: 4. 
Me entretuve descubriendo quiénes eran algunos de los personajes centrales de El zorro de arriba y el zorro de abajo, como los dirigentes sindicales. Mantuve largas conversaciones con quien según mi percepción era el leído Zavala, poderoso secretario de Asistencia Social del sindicato. Recogí información que me permitió identificar la lancha que en el libro de Arguedas se llama Sansón I, comandada por quien la ficción convirtió en el legendario Chaucato. Sobre el real cura Cardozo, un personaje que adquirió protagonismo por sus múltiples actividades en el puerto, escuché innumerables y contradictorias historias.

Imposible no sorprenderse al ver en algunas madrugadas, a varias millas de la costa, las centenas de bolicheras en persecución de la «mancha» de anchovetas. Encontré pescadores anchoveteros de las procedencias más diversas: algunos chiclayanos, por ejemplo, pero sobre todo hombres que provenían de la sierra de Áncash y de Cajamarca. Infinidad de veces vi a los patrones de lancha pagar la semana a su tripulación en alguna cantina del puerto; con los puchos de cada uno —el dinero que iba mas allá de la cifra redonda— se hacía la chancha para la cerveza.

Chimbote estaba dividido en barriadas que albergaban a migrantes de un mismo origen territorial. La prostitución florecía en los hoteles de la ciudad, incluidos los de mayor estatus. En este puerto de machos, los homosexuales paseaban por las calles del centro sin sentirse censurados. Como siempre en la vida, había de las buenas gentes y de las otras. Conocí a muchos Astos, el puneño que en El zorro de arriba y el zorro de abajo aprendió a nadar amarrado al muelle. Admiré cómo los serranos lograban hacerse respetar en un mundo tan adverso para ellos.

Arguedas describe inmejorablemente uno de los mercados cuya actividad también me sorprendió: «Los compradores se empujaban en los pasadizos; los dueños de los comedores les retorcían el pescuezo a las gallinas, haciéndolas girar en el aire, mientas charlaban. A excremento, a frutas, a sudor, a yerbas medicinales, olía la parte techada del mercado. Alcatraces tristes sobrevolaban en el aire, pajareando sueltos, o miraban, con los picos colgantes, desde los techos bajos de las casas y ramadas. Alguna, alguna mujer les arrojaba tripas de pescado o desperdicios de chancho de mar. Si bajaban, los agarraban a patadas, los perseguían a trapazos, a palos; los perros se banqueteaban con ellos» ${ }^{16}$.

Aun así, a pesar de que el tiempo en el que Arguedas estuvo en el puerto y el que me tocó vivir allí fue prácticamente el mismo, el Chimbote que llegué a asimilar no alcanza a ser el hervidero que recrea Arguedas: él accedió a una complejidad mayor. Vio —y, a partir de ello, desveló - ese otro Chimbote, capaz de concitar hasta hoy la atención de lectores y estudiosos de la literatura y de las ciencias sociales ${ }^{117}$.

116 Cfr. Arguedas 1983 [1971]: 62.

117 El mismo Chimbote, por lo demás, en el que, como en un viaje de ida y vuelta, la actividad literaria es especialmente rica en comparación con ciudades del país de su mismo calibre. Obsérvense, por ejemplo, las publicaciones de Ornitorrinco, editorial dirigida por Ricardo Ayllón, y sobre todo las de Río Santa Editores, 


\section{La magia conservadora de Arguedas}

Arguedas afirma con razón que el socialismo no mató en él lo mágico. A pesar de su coincidencia con los afanes de justicia social de los marxistas, se desvincula de los más radicales o «modernizadores», pues reivindica la preservación de la tradición y la cultura quechuas.

Arguedas se preocupa por expresar las vivencias de una cultura dominada y, como él lo dice, arcaizada; pero, simultámente, se sitúa en un presente literario en el que esa misma cultura tiene una vitalidad que se irradia al conjunto de la sociedad peruana. La idea misma de un Perú de todas las sangres expresa esa vitalidad y se insinúa como un punto al que habría que arribar. Pero no porque él sea socialista; no es este el énfasis de Arguedas. Es una visión distinta a las vertientes del socialismo peruano inclinadas a beber preferentemente de una tradición que convoca constantemente a refundar, a reiniciar ${ }^{118}$.

Arguedas es, por el contrario, en estos términos, un preservador de la cultura quechua: su lengua, su arte, su forma de relacionarse con la naturaleza y entre las personas. Sus obras literarias no hablan sobre el devenir; sus reflexiones sí. Es un tradicionalista, un conservador, pero en el sentido de saber «beber de su propio pozo» ${ }^{119}$. No es gratuito que él llame a tomar el Perú como fuente de una creación de valor universal, en contra de la tendencia a cazar gustos y modas procedentes de otros puntos del orbe ${ }^{120}$.

\section{LAS CONEXIONES DE UN SINFÍN DE VOCES PERUANAS}

Su extraordinaria validez como traductor cultural es quizá uno de los rasgos más vigentes y modernos de la producción de Arguedas, no solo porque presenta, mediante sus personajes, las más diversas formas de comunicarse en castellano que tienen los habitantes del Perú, sino porque trabaja conscientemente, a través de la lengua escrita, el vínculo entre la cultura quechua y la criolla.

Dora Sales, traductora española, sintetiza el sentido de lo que representa Arguedas como traductor cultural: «Así, en su literatura, Arguedas batalla por preservar el carácter

dirigida por el poeta y promotor cultural Jaime Guzmán Aranda, entre las que cabe mencionar Llora corazón, novela de Fernando Cueto; Mundo Cachina, crónicas de Augusto Rubio Acosta; Alejandro y los pescadores de Tancay, novela de Braulio Muñoz; Camino a los extramuros, selección de cuentos de Ítalo Morales. Dicho esto sin olvidar al poeta Dante Lecca y al narrador Óscar Colchado Lucio.

118 La imagen de los «iniciadores» de Sendero Luminoso es el caso extremo: «Es tiempo de gran ruptura. Romperemos todo aquello que nos liga al viejo y podrido orden para destruirlo cabal y completamente, pues si en ese mundo caduco tenemos algún interés no podremos destruirlo" (véase www.solrojo. org/pcp_docl pcp_240880.htm).

119 Expresión prestada del libro de Gustavo Gutiérrez Beber en su propio pozo: en el itinerario espiritual de un pueblo.

120 Resulta paradójico que el periodista y novelista estadounidense Tom Wolfe, refiriéndose a la segunda mitad del siglo XX, afirme que a pesar de que «Estados Unidos había enseñado al mundo cuál era el camino correcto en todos los campos, excepto en uno. En cuestiones intelectuales y artísticas seguía siendo una sumisa colonia europea». Cfr. Wolfe 2000. 
pluricultural y multilingüe del Perú, empleando las dos lenguas que conoce, inscribiéndolas en una relación de complementariedad, sin olvidar, como afirma Sara Castro-Klarén ${ }^{121}$, que en esa lucha con el lenguaje se enfrentan y se encuentran no tanto dos lenguas como dos sistemas de percepción, es decir, dos sensibilidades. Y dos ámbitos culturales, como son el oral y el escrito, que el autor tratará de conciliar, lanzándose a la conquista del español escrito para expresar un mundo, un referente quechua, germinalmente oral $\aleph^{122}$.

La forma de hablar de sus personajes expresa esa voluntad de crear un tejido lingüístico rico, diverso y, al mismo tiempo, lleno de vínculos. Es un Babel relativo, porque las personas se entienden. No se reconocen como iguales, pero sí alcanzan a comprender los códigos lingüísticos del otro. Arguedas hace que una cultura sea traducida en el lenguaje de otra sin que pierda su identidad, y reconociendo que tiene distintos grados de fusión con aquella de la que se presta su idioma.

El suizo Martin Lienhard, profesor de literaturas hispanoamericanas y lusitanas de la Universidad de Zúrich, llama a esto la creación de una "polifonía sociolingüística»: «Los dramas del mundo andino se representan como en un escenario teatral. En un principio, cada personaje se expresa en un lenguaje - o sociolecto- que corresponde a su ubicación sociocultural y a las circunstancias de la situación comunicativa. Así, por ejemplo, los mestizos serranos hablan entre ellos en 'español andino', mientras que los indios, cuando se dirigen a ciertos señores, se sirven de un español rudimentario. Unos y otros, cuando se ponen a cantar, lo hacen en quechua»" ${ }^{123}$.

Arguedas desarrolla un fino oído para capturar y recrear voces, y una especial habilidad para dramatizar las historias personales poniendo esas voces por escrito. Un oído y una transcripción de novelista-etnógrafo. De antropólogo urbano también, si se quiere, pero con la valiosa particularidad de incorporar la poesía. No por gusto su sensibilidad por el canto y la música de los Andes, bastante más rica que el indiecito de la postal que toca su quena en la montaña, solo y necesariamente triste, según la mirada parametrada por el menosprecio que nace de la ignorancia del otro ${ }^{124}$.

Arguedas reclama permanentemente la necesidad de reconocimiento del otro, de la instalación de la alteridad entre personas que provienen de diferentes culturas. Es un autor que expresa la fractura de la sociedad, pero también sus vínculos. Como tal, Arguedas, visto a la luz de un autor como Edward Said, representa la resistencia a ser clasificado por el clasificador. Si Said se preocupaba por explicar quiénes eran los autores del orientalismo

121 Cfr. Castro-Klarén 1989: 97-105.

122 Cfr. Sales 2002.

123 Cfr. Lienhard 2004.

124 En la ciudad se sabe mejor ahora que en aquel entonces, en la década de 1960, cuando Arguedas buscaba afanosamente que la capital conociera por ejemplo al charanguista Jaime Guardia y al violinista Máximo Damián. 
y quiénes lo habían definido como tal, Arguedas se preocupa de recordar que los indios no se llaman a sí mismos indios, sino runas.

\section{LOS ACULTURADOS O EL ARTE COMO SALVACIÓN}

Cuando Arguedas dice que él no es un aculturado porque tiene la posibilidad de dialogar con y desde las dos culturas, tan fácilmente como se puede comunicar en español y en quechua, está reivindicando un espacio de encuentro que él considera posible.

Su rotunda y orgullosa afirmación de que él no es aculturado parece una condena a los aculturados. Sin embargo, en el ámbito del debate y de la ficción Arguedas propone una mirada mucho más matizada. No condena a la ignominia el mundo de los mestizos ni el de aquellos que han optado, celebrándolo o sufriéndolo, por asumir formas de hablar, vestir o ser propias de Occidente o del mundo criollo o mestizo-criollo peruano. La tensión se trasluce en el discurso de Arguedas, así como su malestar y frustración frente a la capacidad de engullir del que hace gala el mundo moderno capitalista.

No obstante, no excomulga porque sabe que su experiencia personal es de alguna manera privilegiada y no fácilmente repetible. Además, el mismo Arguedas señala que «Ninguna persona que tenga un mediano conocimiento acerca del Perú, puede generalizar por entero, de manera absoluta, los personajes de la descripción que se hace en Todas las sangres, a todo el Perú» ${ }^{125}$.

Vale la pena recoger la opinión de Alberto Escobar en torno a cómo incluso en Todas las sangres la narrativa del escritor tiende a ampliarse, a ser cada vez más compleja, a incluir nuevas esferas sociales y distintas sensibilidades: «Esta vez asistimos a una expansión, gradual, de la controversia. No falta la figura paternalista y arbitraria, ni el señorío despiadado e inicuo; pero esa voracidad ha encajado en un marco más amplio que la comprende y sitúa dentro de un sistema económico y moral. Es por eso que, conforme se desarrolla la trama, la problemática se amplía como el fuelle de un acordeón, y difunde el abuso, el despojo, la usurpación, el empobrecimiento material y ético. Y cada uno de estos pasos se ilustra con varias resonancias subjetivas, con las distintas réplicas sociales, con la transformación de los hombres y de un carácter en el discurso general de la historia» ${ }^{126}$.

Arguedas se resiste a ser un indigenista convencional, porque esta corriente lleva implícita una mirada externa al indio, si bien acogedora, lo que lleva casi sin remedio al esquematismo. El reto de Arguedas es complejo porque se propone escribir como quechua, pero haciendo uso, consciente y calculadamente, de una lengua universal.

En la mesa redonda del Instituto de Estudios Peruanos sobre Todas las sangres (23 de junio de 1965), respondiendo polémicamente a unas observaciones hechas por el cientí-

Cfr. Varios 1985: 46.

126 Cfr. Escobar 1965: 44. 
fico social Henri Favre, Arguedas apunta sobre uno de sus personajes centrales de Todas las sangres: «Esa es la imagen que usted ha percibido. Pero Rendón Willka no es indio, no es indio Rendón Willka. Rendón Willka no cree en los dioses montaña, se vale de esa creencia para llegar a un fin político, es totalmente racionalista. No es indio, en ningún momento aparece como indio. Es ateo, no cree ni en el Dios católico ni cree en los dioses montaña y él considera que la máquina, que la técnica, es indispensable para el desarrollo del país» ${ }^{127}$.

Arguedas no envía a Rendón Willka al campo de los traidores ni lo sataniza. Lo presenta como un personaje conflictuado, duro, dispuesto a una que otra maldad, que se aleja del mundo quechua, pero que es parte y expresa la gama cultural del país ${ }^{128}$.

Arguedas reconoce perfecta y realistamente los costos personales, sociales y culturales del aculturamiento, y en El zorro de arriba y el zorro de abajo se lo hace decir a uno de sus personajes (Zavala) a propósito del puneño Asto: «Se fue silbando un huaino, cruzando las otras filas de clientes. Zavala lo vio irse. 'Pisa firme ahora - dijo- Camina firme, silba firme ese indio. Desnudo, amarrado al muelle, días de días aprendió a nadar para obtener matrícula de pescador. No hablaba castellano. ¿Cuál generosa puta lo habrá bautizado? Desde mañana fregará a sus paisanos, será un Caín, un Judas'» ${ }^{129}$.

Arguedas, sin embargo, sabe que también los aculturados pueden sentir en dos idiomas. ¿O solo los no aculturados tienen la posibilidad de pensar, cantar y hablar en dos idiomas? La tensión persiste, pero Arguedas tiene personajes memorables que son definitivamente mestizos. Mestizos que niegan o se resisten a reconocer su procedencia y de los que asumen contradictoriamente, y a veces a escondidas, su imborrable y negada tradición.

\section{Más ALLÁ O MÁS ACÁ de la RAZÓN}

La cultura de los runas es poderosa y ha permeado crecientemente los más diferentes intersticios de la sociedad peruana. Si las migraciones masivas del siglo XX transforma-

\footnotetext{
127 Cfr. Varios 1985: 46.

128 Según José Carlos Ballón, filósofo de la Universidad Nacional Mayor de San Marcos, Arguedas produce tres giros claves en la narrativa denominada «indigenista»: «En primer lugar, la incorporación [...] de instrumentos de la metodología analítica de recopilación de información y evaluación de datos de la antropología académica estadounidense de mediados del siglo XX, que él seguramente asimiló cuando ingresó a mitad de la década de 1940 al Instituto de Etnología de San Marcos. [...] En segundo lugar, [...] La demolición arguediana de la imagen monolítica y estereotipada del mundo andino que hasta entonces caracterizó a la narrativa indigenista, convierte al mundo andino en un conglomerado heterogéneo» $y$, en tercer lugar, "[...] había que instalar la utopía no en el pasado — como se venía haciendo hasta entonces [...] —, sino en el presente sensible. Ello confronta la narrativa indigenista con el reto impensable hasta entonces de instalar la ficción monolítica en un presente que se multiplica en grupos endiabladamente heterogéneos». Cfr. Ballón 2006: 56-57.
}

129 Cfr. Arguedas 1983 [1971]: 43. 
ron radicalmente el paisaje humano de las ciudades y de los campos serranos, también provocaron cambios traumáticos en las ciudades costeñas que los recibieron. El número de peruanos que hablan quechua o aimara — los monolingües o bilingües — se redujo sustantivamente en los últimos cincuenta años. No obstante, simultáneamente, el país se ha vuelto más andino, más mestizo, más serrano.

El Chimbote de El zorro de arriba y el zorro de abajo es una clara dramatización de que Arguedas está dispuesto a reconocer la mugre, la violencia y el olor de Chimbote como uno de los espacios donde se produce ese proceso de fusión de culturas. En este libro existe más de un ejemplo sobre cómo su autor reconoce expresamente que los personajes provenientes de las culturas andinas deben mimetizarse con las costumbres del vencedor. Los puneños están dispuestos a ser amarrados en el muelle del puerto para aprender a nadar; Asto intenta mostrar su poder en un prostíbulo de Chimbote cuando recibe su primer pago por su trabajo como pescador.

¿Creía Arguedas que es posible preservar ese espacio que él había configurado para sí? Es una interrogante de difícil respuesta. No obstante, siendo el componente andino vigoroso, creativo y extraordinariamente resistente en el proceso de fusión de culturas, prevalecían los símbolos sociales y de poder de la cultura criolla. En ese contexto, el arte asoma como un dato de esperanza. Arguedas reconoce que existía un proceso social, cultural, económico y político que se desenvolvía contra sus propios deseos.

La literatura de Arguedas parte del supuesto de que para conocerse - las personas y las culturas - son cruciales los sentimientos, la imaginación, el idioma. No es que la literatura de Arguedas exprese una voluntad irracional. Sin embargo, la importancia de la alegría y del sufrimiento, y el especial papel del canto, de la música y del habla (no hay que olvidar que el quechua es una lengua fundamentalmente oral) terminan por ser decisivos para comprender al otro y para conocerse uno mismo.

La empatía es clave para relacionarse. Por eso, el sentirse maltratado no es un asunto primero racional, sino sobre todo de consideración, de reconocimiento, de estima y de autoestima. Los personajes de Arguedas se desplazan en este precario espacio de la incertidumbre, entre ser reconocidos o des-conocidos por los otros ${ }^{130}$. Es lo que Ernesto, el personaje de Los ríos profundos, transmite permanentemente en relación con sus compa-

130 Gonzalo Gamio, filósofo, docente de la Pontificia Universidad Católica y de la Universidad Antonio Ruiz de Montoya, en una reflexión sobre la Comisión de la Verdad que investigó los años de violencia política en el Perú de 1980 a 2000, trae a colación, a propósito del desconocimiento, el «célebre relato» de Arguedas titulado «El sueño del pongo»: «El narrador cuenta que el pongo cumplía con los requerimientos burlones del patrón —así como sus propias labores domésticas — en el más absoluto silencio. Parte de la humillación consistía precisamente en privarlo del uso del lenguaje, un rasgo específicamente humano. [...] El pongo obtiene una clase de justicia - cierta satisfacción en contraste con el maltrato sufrido-. Cuando obtiene el permiso para dirigirse a su patrón, le habla desde el horizonte de su dignidad y sus demandas de respeto incondicional. Es justamente a la luz del discurso del viejo pongo desde donde puede reconocerse el verdadero lugar de cada cual, la sabiduría del siervo, y la insignificancia moral del 'señor”». («Poder vivir todas las patrias. La Comisión de la Verdad, Arguedas y la justicia». Cfr. Gamio 2005. 
ñeros de colegio en Abancay o cuando se deslumbra con las piedras de los muros incas del Cusco; o cuando Santiago, el personaje-niño de su cuento "El viejo horno», se ve obligado a presenciar una violación.

Todos los sectores sociales, por otro lado, han sido tocados por el proceso de desarraigo de los serranos; incluso los sectores más privilegiados, que entregan a sus hijos a la crianza de mujeres jóvenes de la sierra o de padres o abuelos serranos. Las empleadas domésticas han sido uno de los conectores más poderosos entre esos mundo lejanos. Es cierto que son muchas objeto de desprecio y maltratos o que se ven forzadas a esconder su cultura y su origen. Pero su forma de ser, de imaginar, de hablar, de querer, de tener miedo es trasmitido por los poros de esa sociedad criolla que las puede despreciar, pero que, a su vez, requiere de ellas.

En las décadas de 1950 y 1960 los hogares de Lima y de las principales ciudades de la costa y de la sierra vivían esos contactos interculturales de los que Arguedas escribe. No se requería conocer una comunidad campesina para tomar contacto con ese otro país. Ese Perú estaba incrustado en el seno mismo de los barrios y de las familias más adineradas. Por eso, si se lo quiere escuchar y sentir, Arguedas puede ser entendido y sentido desde los barrios de las clases altas y medias de la capital.

Los gamonales vivían en los latifundios de la sierra, pero el estilo patriarcal o patrimonial pervive en las grandes ciudades. El trato servil sigue vivo en los barrios y las familias más modernas.

\section{A MANERA DE EPÍlogo: Mito y FUTURO}

Muchos colegios llevan su nombre, así como innumerables promociones de universidades y de escuelas secundarias, a lo que hay que sumar la continua reedición de sus obras. ¿Por qué Arguedas sigue tan vigente en el imaginario nacional? ¿Qué fibras toca Arguedas que siguen suscitando reacciones (y creaciones) en disímiles peruanos? ${ }^{131}$. Los mismos títulos

131 Al respecto, vale la pena mencionar dos composiciones musicales: «José María Arguedas» un pumpin del compositor Eusebio Huamaní Rodríguez interpretado por el conjunto Huaylla Ichu de Huancapi, o el huaino "Arguedasninchik», del puquiano Edwin Montoya.

Sirva también como bella muestra el poema-homenaje escrito por Miguel Ildefonso (Lima, 1970): «José María venía en bus, por La Oroya, a Lima, / en sus audífonos escuchaba a Lou Reed; / afuera los cerros mojados, la lluvia entrándole por el hueco de la bala. / [...] / Con una mano cogiste el arma, yo nacía cuando te despedías. / Tres días antes cantaste en una reunión con amigos, / alguien grabó tu voz y aquella grabación fue una burla a la muerte / que siempre te acechó, fue tu victoria / sobre una prole de intelectuales. / Un día antes fuiste a La Parada a comprar discos de huainos; / nos emborrachamos escuchando a Jilguero; / nos vemos mañana, tú naces yo muero, cantabas. / Habrías tenido un flash back, tu infancia entre los indios, / una clase en la universidad, o algo como una retama / que al comienzo te hiciera dudar, / pero que luego más bien te impulsara con una fuerza irrefrenable. / José María, una mujer canta en la esquina de mi calle, / viene de Ayacucho. ¿¿Estaré yo en su canto? / ¿Estarán mis poemas en la palma de esa mano de barro? / José María, tú cantabas en quechua un rock en el fondo de mi tumba. / Yo escribo esto para cantar en ti» (véase la versión completa en letras.s5.com/mi021206.htm). 
de sus principales obras literarias se han convertido en grandes síntesis o mitos de una especie de unidad nacional e inalcanzable: Todas las sangres o El zorro de arriba y el zorro de abajo expresan, en metáforas densas y extraordinariamente visuales, la idea de una unidad nacional diversa, contradictoria, resistida y, a su vez, añorada, porque es muy contraria a la experiencia que se vive como comunidad nacional.

De la empatía que originan algunos de los personajes de Arguedas peor tratados, sea por terratenientes, jefes de empresa, autoridades políticas o incluso familiares, surge el mito de que el reconocimiento es central para la existencia de una comunidad nacional.

Se constituyó en un gran fabulador. Si hay un mito que Arguedas intenta que se consolide en sus lectores es el del diálogo entre distintas culturas, aunque sus novelas estén cargadas de sangre, intransigencia y conflicto. Es la constatación de una posibilidad, pero también es un ferviente deseo.

En tiempos de globalización y de poderoso resurgimiento de la diversidad cultural, la obra de Arguedas tiene una extraordinaria actualidad y expresa de manera admirable intuición que el diálogo con el otro es indispensable para alcanzar reconocimiento e identidad. Si los quechuas requieren el reconocimiento de los criollos para «humanizarse», en una sociedad que tiene claros resabios estamentales, los criollos necesitan también ese reconocimiento de parte de los distintos pueblos que habitan el Perú para alcanzar un propósito similar.

\section{Bibliografía}

ARGUEDAS, José María (1983 [1971]). En: El zorro de arriba y el zorro de abajo. Lima: Editorial Horizonte.

BALLÓN, José Carlos (2006). «Entre la utopía indigenista y la utopía modernista». En: revista Quehacer, nro. 160. Lima: Desco, pp. 56-57.

CASTRO-KLARÉN, Sara (1989). «Mundo y palabra: hacia una problemática del bilingüismo en Arguedas». En: Escritura, transgresión y sujeto en la literatura latinoamericana. Tlahuapán, Puebla: Premià, pp. 97-105.

ESCOBAR, Alberto (1965). «La guerra silenciosa de Todas las sangres». En: Revista Peruana de Cultura.

GAMIO, Gonzalo (2005). «Poder vivir todas las patrias. La Comisión de la Verdad, Arguedas y la justicia». En: Arguedas y el Perú de hoy. Lima: Sur.

GUTIÉRREZ, Gustavo (1983). Beber en su propio pozo: en el itinerario espiritual de un pueblo. Lima: Centro de Estudios y Publicaciones.

ILDEFONSO, Miguel. En: letras.s5.com/mi021206.htm.

LIENHARD, Martin (2004). «La traducción del mundo andino. El español y el quechua en las literaturas del Perú andino». En: Congreso Internacional de la Lengua Española, Rosario, Argentina.

SALES, Dora (2002). I Congreso Internacional de Traductores e Intérpretes. Lima: Colegio de Traductores del Perú y universidades Femenina del Sagrado Corazón y Ricardo Palma. 
VARGAS LLOSA, Mario (2008). «Tiburones en formol». En: El Comercio, 5 de octubre, p. 4.

VARIOS. (1985). La mesa redonda sobre «Todas las sangres» del 23 de junio de 1965. Lima: Instituto de Estudios Peruanos.

WOLFE, Tom (2000). El periodismo canalla y otros artículos. Madrid: Ediciones B. 

Fernando Belaunde Terry

(1912-2002)

Miguel Cruchaga 

En el mismo momento en que el Heyho Maru cruzaba la línea ecuatorial, Belaunde dejaba atrás una crucial etapa de su juventud, matizada por la nostalgia y el asombro. Navegando desde el puerto mexicano de Manzanillo, pensaba: «Mañana amaneceremos en Paita y podré, por fin, pisar suelo peruano». Regresaba al Perú, con veinticuatro años recién cumplidos, luego de haber pasado la mitad de su vida en el exilio. La familia emigró en 1924, cuando Belaunde era todavía un niño. El crepúsculo trajo a su memoria los recuerdos y las añoranzas acumuladas en esos años. Para aplacar su vehemencia, buscó, entre la bruma y la oscuridad, los destellos distantes de algún puerto peruano.

Sentía una exaltación parecida a la de la noche del 21 de mayo de 1927, cuando aterrizó en París el «Espíritu de San Luis». Charles Lindbergh acababa de atravesar el Atlántico por primera vez en una pequeña avioneta y un clima de inusitada algarabía invadía los bulevares y las calles de la Ciudad Luz. En el número 58 de la avenida Wagram, los Belaunde Terry vivían centrados en un solo tema: pensando, hablando y soñando con el Perú. Contaban los días que quedaban (las estimaciones eran bastante flexibles), para que terminara el Oncenio y acogían a los pasajeros ocasionales dispuestos a compartir cualquier información que alentara sus esperanzas. La noche del aterrizaje, Belaunde se sintió cargado de intensa exaltación. Lo entusiasmaba la hazaña del aviador solitario, la magnitud de su coraje y fuerza de voluntad, también la tenacidad que lo mantuvo despierto durante las treinta y tres horas y media del vuelo. Esa noche descubrió nuevas facetas de sí mismo; regocijos desconocidos que el arrojo del larguirucho piloto despertaron, llenándolo de una inquietud y un apremio que lo acompañarían el resto de su vida.

Tenía, sin embargo, una admiración más antigua. La que le suscitaba el viejo líder francés Georges Clemenceau, suerte de «símbolo moral» galo; la sola mención de su nombre henchía de orgullo y producía efectos balsámicos a los franceses y les servía para paliar los sinsabores que la guerra reciente les había dejado. Keynes ha dicho que: "Clemenceau sentía por Francia lo que Pericles por Atenas —estaba convencido que su valor singular era tal que nada más podía importar...»' . Acaso contribuyó a forjar la singular admiración del escolar por el anciano estadista, cierta emulación por la devoción que su padre profesaba por Piérola. En la cátedra de la mesa familiar, don Rafael recordaba siempre las

1 Cfr. Keynes 1919. 
hazañas del Califa y repetía sus discursos y sentencias de memoria. En uno de sus juegos adolescentes, Belaunde se enfrascaba en torneos dialécticos con su hermano Rafael, comparando conductas históricas entre Alemania y Francia. Del lado francés, Belaunde no se dejaba persuadir por la mayor erudición de su hermano, sosteniendo la posición contraria. El recibir la educación secundaria en un medio que siente una singular veneración por la patria contribuyó a que desarrollara un sentimiento similar por el Perú. Se podrá pensar que ese sentimiento es común a todas las naciones. En pocos lugares, sin embargo, existe con la profundidad y solidez con las que se produce entre los franceses.

Sus últimos años como estudiante de Arquitectura los había pasado en Texas. Ello le facilitaba visitar México con frecuencia, donde su padre se desempeñaba como embajador. La Revolución mexicana se estabilizaba y era notable el sentimiento de orgullo nacional que se percibía en la calle. Si bien este no era un fenómeno enteramente nuevo, se había potenciado en esos años. Una mezcla de admiración y curiosidad lo condujo a prestar atención a los posibles factores desencadenantes de este hecho. Así descubrió a José Vasconcelos, un intelectual sobresaliente, autor de La raza cósmica, escrita en exaltación de los pueblos autóctonos, que condena el racismo implícito por el hecho de que los trabajos más duros y subordinados se reservaran solo a los indígenas. Además de escritor vigoroso y justiciero, Vasconcelos fue un gran impulsor de la educación pública, y un luchador infatigable por la institucionalización de una sociedad todavía sujeta a las arbitrariedades autoritarias que venían tanto del pasado cuanto del periodo inicial de la revolución. Debido a su inteligencia y cultura, se había convertido en una de las personalidades más relevantes de la época y en el orientador sustancial de la identidad que iba cuajando esa nación de raíces volcánicas y aguerrida herencia indígena y española.

Pero lo que terminó de fascinarlo con México fue el alegre colorido del folclore, la fuerza expresiva de los muralistas y la magia hechizante de las corridas de toros. La fiesta lo embrujó hasta convertirse en el acontecimiento del que más gozaría. Desde que asistió a su primera corrida, nada consiguió igualar la emoción de la plaza. Cada salida del toro, cargada de furia y amenaza, a un ruedo encendido de luz y vibrante expectativa, le parecía el espectáculo más formidable. Lo fascinaba constatar que a la fuerza arrolladora solo puede doblegarla la parca elegancia del valor; que el coraje solo sirve cuando es auténtico, pues no se puede fingir y proviene principalmente de una manifestación misteriosa e indomable del espíritu. Acaso le permitía terminar de entender la severa consigna que su padre le repitiera desde la infancia: «Perfección vía control».

Enfrascado en esos pensamientos, a ratos dormitando, despertó finalmente, la mañana de su regreso al Perú. Sintió cómo crecía su exaltación, a medida que se acercaba — por fin- la hora de pisar suelo peruano. Con cada segundo que pasaba, estaba más cerca del territorio de todas sus nostalgias, del lugar del que provenía el llamado de la sangre y eso que John O'Donohue denomina «el sentido de pertenencia». Quiso poner en orden sus 
ideas y entonces pensó: «A lo largo de la historia, se ha repetido una sucesión recurrente de conquistas. Cada etapa dejó la población dividida entre conquistadores y conquistados. Los incas conquistaron a las etnias autóctonas vecinas, los españoles conquistaron a los incas, los ejércitos criollos sudamericanos, encabezados por generales argentinos y venezolanos, conquistaron nuestra independencia, mientras los peruanos luchábamos indistintamente en ambos lados del campo de batalla. La guerra que tenemos pendiente es distinta a las anteriores y consiste en la conquista del Perú por los peruanos».

«Este es nuestro desafío — pensó-: que todos los que compartimos la honrosa condición de peruanos decidamos asumir una tarea común, capaz de ponernos del mismo lado de la trinchera. Este reto, como suele pasar en la historia, está ligado a una conquista territorial. Pero no para arrebatársela a algún vecino, sino para terminar de incorporar, como lo han hecho las grandes naciones, la totalidad del propio territorio, conquistando plenamente, en nuestro caso, el oriente peruano. Incorporando la ceja de selva mediante una gran carretera longitudinal, se incrementaría significativamente la extensión agrícola y se aprovecharían mejor las aguas de las dos vertientes de nuestras cumbres andinas. Ante el peligro de congestionar Lima y las principales ciudades de la costa, se debería alentar una mejor distribución poblacional, creando nuevos polos de desarrollo en la ceja de montaña, en los que surjan nuevas oportunidades de trabajo productivo. Pero conquistar es más que eso; empieza por uno mismo, dominando la capacidad de elevarse por encima de las propias miserias. Ello supone que nos asumamos unos a otros, aceptando primero y desarrollando después, el orgullo de nuestro ser mestizo y pluricultural. Alcanzar una suerte de convergencia de 'hermanos pródigos' reencontrados después de tantos y tan dolorosos desencuentros y abandonos. Conquistar nuestra capacidad de escucharnos con asombro y entendernos con generosidad».

En la memoria de los que participamos de sus primeras campañas, reverbera todavía la ilusión de ese reencuentro y la promesa de lo que habría de traer. Implicaba aprender a sobreponerse al derrotismo y la inclinación pesimista que ha perjudicado tanto al Perú, a lo largo de la historia; a la tentación fatua de creer que, con cada nuevo gobierno o cada nueva generación, empieza de nuevo la historia.

Soltaron el ancla pasadas las siete de la mañana. Un lanchón se aproximaba desde el litoral, a dos kilómetros de distancia. Belaunde se había asegurado el derecho a bajar a tierra durante la breve escala. Solo lo acompañaría su hermano Francisco. Sus ojos fijos en la línea costera, aguardaba estático la llegada a la tierra prometida. Estando cerca, pudo ver mejor las modestas instalaciones del puerto, el confuso desorden del entorno; el bullicio de hombres gruesos de torso descubierto, cargando y apilando costales, cantando un castellano lleno de modismos y de áspera dulzura. Trémulo y con la sonrisa congelada, bajó a tierra y dejó desbordar su fascinación, integrándose al dinamismo del puerto. No había demasiado que ver pero su satisfacción fue inmensa. Se sintió colmado por la belleza árida 
del paisaje y el rostro risueño y amigable de los estibadores, parecidos en el colorido, los bigotes y la entonación a los que había dejado, días atrás, en Manzanillo.

Caía la noche de la primera amanecida. Habíamos empezado a estudiar Arquitectura hacía unos meses y sabíamos de sobra que este era el precio a pagar —al menos en la universidad - por la gestación de cada proyecto: quedarse de sol a sol, inclinados sobre los tableros de dibujo, pretendiendo atrapar con infinitos bosquejos, alguna idea escurridiza. Resultaba mejor hacerlo en compañía. Las bromas y el bullicio ayudaban a ahuyentar la soledad y a derrotar la tentación del cansancio. Lima lucía apacible y lejana, desde el único taller encendido de la facultad. Rodeada de campo, cerros y silencio, la Universidad Nacional de Ingeniería parecía deliberadamente instalada al margen de la ciudad. Esa ubicación, llegada la noche, inducía la idea de abandono.

Débiles luces vibraban desde el sur. Entre ellas, dos faros gemelos que se acercaban en nuestra dirección. Los vimos aproximarse lentamente. «Probablemente va camino a Canta», dijo alguno. Sorprendidos, observamos cómo giró a la derecha e ingresó al campus. Un buen presagio nos atropelló escaleras abajo a encontrar al visitante. Descubrimos al decano y a su esposa abriendo la maletera del Mercury blanco. De ella asomaba una olla humeante.

De regreso en el taller, rodeamos expectantes la olla que Carola Aubry abría con gracia de prestidigitadora. Un sabroso arroz chaufa la colmaba y un olor apetitoso y redentor empezaba a entonarnos. «¿Cómo van?», inquirió Belaunde. Nos observaba con calidez, pero también con cierta impaciencia. Le respondimos vaguedades. Momentos después, lo escuchábamos fascinados. Había regresado al Perú en 1936. Encontró apenas un puñado de arquitectos; la mayoría de ellos venidos de estudiar fuera. La universidad, hasta hace poco Escuela de Ingenieros, agregaba un curso a los estudios de Ingeniería Civil, para otorgar el título de ingeniero-arquitecto. Era insuficiente. Había que ofrecer una formación más completa y convertirla en una profesión independiente, como ocurría en Europa y en Estados Unidos. Además, promover entre los graduados el espíritu de cuerpo e introducir la nueva profesión al país.

Sus primeras iniciativas, orientadas a responder estos desafíos, fueron: publicar una revista de arquitectura, incorporarse a la enseñanza universitaria y contribuir a la creación de una asociación profesional. Las tres con un claro sesgo institucional. Belaunde estaba convencido de que la mejor manera de promover el desarrollo consiste en amalgamar dos factores complementarios: el espíritu de emprendimiento de la iniciativa privada y la capacidad reguladora y subsidiaria del Estado. Sabía que no es posible alcanzar un progreso verdadero sin la interacción concertada de ambos. Cuando domina el espíritu de empresa, las sociedades agudizan sus diferencias y tensiones y evolucionan por caminos 
que desembocan en el egoísmo extremo, la arbitrariedad y, finalmente, la violencia; cuando predomina la autoridad tutelar del Estado, decae la creatividad de los ciudadanos, se reduce la productividad y aparecen, inevitablemente, la mediocridad, la impunidad en el desacierto, la corrupción y las castas privilegiadas. Ambos peligros se superan articulando un modelo que los equilibre y contrapese, implantando un sistema abierto a las críticas y las disensiones, regido por un orden legal estricto e instituciones encargadas de preservarlo, actualizarlo y hacerlo cumplir. Las asociaciones gremiales o sectoriales y la prensa cumplen, a este respecto, el indispensable rol de bisagra articuladora de las necesidades de la iniciativa privada y el rol regulador del Estado. De esta manera, se compensan mejor los desniveles y las injusticias derivadas de las diferencias en educación y capacidad económica que presenta la realidad y también los riesgos de que el poder sea impermeable a los requerimientos de cambio y sensatez. El orden democrático debe ser inquebrantable y quienes lo lideran, capaces de despertar y alentar la nobleza ciudadana, para suscitar el espíritu de solidaridad y generosidad indispensables para una coexistencia armoniosa.

Cada fin de mes, los arquitectos aguardaban la llegada de su revista. Era el vínculo regular entre ellos y el medio para recargar el ánimo y estimular la creatividad. La primera edición de El Arquitecto Peruano apareció en agosto de 1937. Estrictamente, no podía estar dirigida solo a los arquitectos, pues no había suficientes. Apuntaba a un público amplio, al que pudiera enseñarle a apreciar la arquitectura; darle a conocer sus novedades e informarle acerca de la evolución de las tecnologías.

Belaunde la dirigió durante veintiséis años, hasta que asumió la presidencia por primera vez, en julio de 1963. Su gravitación fue muy grande y sirvió para introducir los principales temas de la arquitectura, el planeamiento urbano, las políticas de vivienda, la preservación del patrimonio monumental y la valoración de la arqueología. Se publicó durante cuarenta años, hasta mediados de 1977. Fue una tribuna abierta y plural en la que colaboraron los principales arquitectos del medio. Su objetivo central fue difundir y prestigiar la arquitectura realizada en el Perú.

En una de sus primeras ediciones, informó que, un mediodía de octubre de 1937, en una reunión realizada en La Cabaña, un grupo de diecisiete arquitectos constituyó la Sociedad de Arquitectos y eligió su primera directiva, cuya secretaría recayó en el propio Belaunde.

El Departamento de Arquitectura se creó en la Escuela de Ingenieros en 1948, poco tiempo después de que Belaunde se incorporara como profesor. Asumió su dirección, como primer paso para independizar la carrera. Dos años más tarde, lo consiguió. Entonces asumió el decanato de la primera Facultad de Arquitectura peruana. En ella introdujo un moderno programa de estudios cuya estructura esencial sigue sirviendo de modelo a la infinidad de programas actuales. 
Inicialmente, todas las carreras se concentraban en un solo pabellón, al que se habían mudado poco tiempo atrás, de la calle Espíritu Santo. La nueva propiedad, en el extremo norte de la ciudad, estaba rodeada de extensos terrenos agrícolas y reservas para el crecimiento del campus. Belaunde fue el primer decano - y acaso el único— que gestionó y llevó adelante la edificación de su propia sede sin emplear recursos financieros de la universidad. Supo movilizar la generosidad de sus colegas, de los comerciantes e industriales de la construcción, y también de los trabajadores y alumnos. A cada nueva promoción, se le inducía a contribuir con algo hasta completar la obra inconclusa. Constituía una suerte de bautizo del que salían los estudiantes con las manos laceradas y el espíritu hinchado de orgullo.

Los alumnos del cuarto año esperaban a Belaunde con expectativa. Sus clases - sobre temas de vivienda - eran muy atractivas. Explicaba un concepto que luego ilustraba en la pizarra (o en proyecciones) con imágenes. Usaba un puñado de tarjetas con citas de arquitectos o autores relevantes y las leía con énfasis y dicción impecables. Luego, proponía que dibujaran un esquema capaz de sintetizar los conceptos explicados. Después de recoger el ejercicio, repartía unas hojas en las que aparecían esquemas similares, escogidos entre los mejores producidos por las promociones anteriores y los comparaba con los nuevos. Esto le servía para resaltar los aspectos soslayados y así evitar que pasaran desapercibidos. En seguida, entraba en el tema siguiente, que desarrollaba con ritmo y amenidad parecidos. Otro tanto sucedía con sus clases en Ingeniería Civil —en las que hablaba de urbanismo— ante grandes grupos. Sus clases eran bastante concurridas porque atraían a los muchachos y despertaban en el auditorio tonificante entusiasmo. Estaban orientadas a promover inquietud por las materias, no a enseñarlas de manera enciclopédica. Le apasionaba hablar sobre la vivienda social y el desarrollo infraestructural que abriría paso a la promesa de un futuro mejor para el Perú. Cuando culminó su gestión en 1961, dejó una facultad exitosa y prestigiada, con una población de algo más de doscientos estudiantes. Entre ellos, destacaba la presencia de numerosos colombianos, venezolanos y bolivianos, que venían especialmente a estudiar la carrera en Lima.

Frente a la facultad se había edificado el Instituto Interamericano de Planeamiento de Lima, programa de postgrado, promovido por la facultad, como consecuencia de la introducción, años antes, de la enseñanza profesional del urbanismo a iniciativa del mismo Belaunde. Funcionó con el patrocinio de la Organización de Estados Americanos (OEA) y la asesoría académica de la Universidad de Yale. En sus aulas podían encontrarse - además de limeños - egresados de distintas especialidades provenientes de provincias y de varios países de la región.

En 1945 se adhirió al Frente Democrático Nacional, constituido para postular la candidatura presidencial de José Luis Bustamante y Rivero. Convocado por este, postuló y fue elegido diputado por Lima, luego de incorporarse a la campaña como secretario de prensa. 
En el Congreso fue autor de importantes iniciativas orientadas a institucionalizar el desarrollo urbano y habitacional del país. A él se debe la creación de la Corporación Nacional de la Vivienda, el plan de «unidades vecinales», considerado un modelo latinoamericano; la Oficina Nacional de Planeamiento y Urbanismo, encargada de formular los planes reguladores de las diversas ciudades del país; el plan de «centros vacacionales» (de los que solo se llegó a construir el de Huampaní); y la Ley de Propiedad Horizontal, que permitió otorgar títulos de propiedad independientes a los departamentos de edificios multifamiliares.

Las «unidades vecinales» se inspiraron en una idea británica: la «ciudad jardín». En la versión peruana, conjuntos de mediana altura, apostados en el perímetro de un gran terreno, cuentan con parques, campos deportivos, escuela, centro comunitario, iglesia, etcétera. Es el caso de la Unidad Vecinal 3, San Felipe, Angamos, Santa Marina, Mirones, Matute, Torres de San Borja, Limatambo, Julio C. Tello y Santa Rosa, en Lima, e infinidad de conjuntos similares en las ciudades más importantes del país. Al quedar el automóvil limitado al estacionamiento periférico, las familias y los niños recorren su vecindario libres de peligro. Producen un hábitat agradable en el que las áreas verdes compensan adecuadamente la densidad de los multifamiliares. Cabe comparar la diferencia que existe entre esos conjuntos y los densos edificios que se construyen ahora, saturando de cemento la integridad de los terrenos y cargando el panorama urbano de un aspecto crecientemente agobiante.

Lo que más impresionaba de entrar a su despacho era la presencia ordenada y numerosa de decenas de tomos idénticos. La simetría de dimensiones y colorido sugerían la presencia de una enciclopedia infinita. En cierta medida lo era, pues consistía en la acumulación de los volúmenes de proyectos de grado, dirigidos por él, durante años. Iniciaba siempre el diálogo con alguien a quien acababa de conocer preguntándole por el lugar de su procedencia familiar. Luego seguía un intercambio de datos sobre la región, sus recursos y posibilidades, al que agregaba algunas preguntas de tipo general. De esta manera encontraba temas para nuevos proyectos de grado. Con esta modalidad, había estimulado y dirigido el estudio de infinidad de iniciativas de ingeniería, en la mayor parte del territorio nacional: represas, puentes, caminos e irrigaciones se almacenaban en un vasto inventario cargado de propuestas ingeniosas y de gran potencial. Las explicaba con intensidad, sacando un tomo y buscando entre sus páginas hasta llegar al plano descriptivo de la idea o la estadística probatoria de su factibilidad.

Esos trabajos constituyeron el inventario de proyectos que sirvió de base para muchos de los programas infraestructurales que puso en marcha desde el gobierno. Estaban referidos principalmente a la red de carreteras, que consistía en completar la trama tejida con hilos longitudinales: la costeña Panamericana, la longitudinal de la sierra y la Marginal 
de la Selva y un amplio complemento de hilos transversales integrado por las vías de penetración que atraviesan la escarpada geografía, preferentemente en los lugares en los que existe algún puerto costeño. También, la red eléctrica y su interconexión para suplir el abastecimiento de zonas que pudieran sufrir algún déficit. Asimismo, la construcción o ampliación de las centrales hidroeléctricas, comprendiendo que no hay desarrollo posible sin energía suficiente. Finalmente, las represas y los sistemas de irrigación destinados a ampliar las posibilidades productivas de los valles agrícolas del Perú. Todo esto complementado por un conjunto de puertos y aeropuertos destinados a facilitar el intercambio de pasajeros y productos.

Sube a nacer conmigo, hermano.

Dame la mano desde la profunda zona de tu dolor diseminado.

$[\ldots]$

Mírame desde el fondo de la tierra, labrador, tejedor, pastor callado;

$[\ldots]$

señaladme la piedra en que caísteis,

y la madera en que os crucificaron,

[...]

Dadme el silencio, el agua, la esperanza.

[...]

Hablad por mis palabras y mi sangre.

La voz cansina y nasal de Pablo Neruda resonaba en la habitación. Provenía de un disco en el que estaba grabado «Alturas de Machu Picchu». El escritorio de la casa de Inca Ripac era el vértice de una planta en forma de «L». Todo conducía a ese lugar, donde se encontraban las dos alas. Enchapado con paneles de madera, abundantes libreros y una chimenea central sobre la que colgaba un óleo de su bisabuelo paterno, el general Pedro Diez Canseco. La inspiración sajona del decorado producía un ambiente sobrio e íntimo. Las reuniones en casa de los Belaunde terminaban siempre allí, cerca del equipo de música, en unos cómodos sofás de esterilla con mullidos cojines tapizados en terciopelo ocre que inducían la tertulia. "Quería que escucharas este disco para que aprecies el poder de la palabra — dijo—. La palabra es capaz de producir grandes transformaciones. Cuando llegué a Estados Unidos, en 1930, tuve oportunidad de comprobar el tremendo decaimiento producido por la depresión del año anterior. Las calles estaban atestadas de vendedores ambulantes y colas de gente esperando algo que comer en las ollas comunes instaladas cerca de las parroquias. El 
desempleo había superado $25 \%$ de la población trabajadora y el pesimismo era creciente. El modelo norteamericano parecía haber alcanzado su crisis terminal».

Continuó: «Una noche, cuando me aprestaba a iniciar un trabajo universitario, encendí la radio. A los pocos minutos fui captado por una voz extraordinaria. Era Franklin D. Roosevelt, que iniciaba su primera campaña presidencial. Hablaba con elegancia; la calmada dicción con la que pronunciaba sus palabras inducía tranquilidad y deleite auditivo. Se sentía, además, detrás del tono elocuente, una suerte de optimismo ontológico del que no se podía evitar sentirse contagiado. Cuando el contenido del discurso empezaba a extraviarse por algún desvío de posible solemnidad, una broma —o un juego de palabraslo regresaba a la naturalidad original. Roosevelt sacó a Estados Unidos de la depresión mediante una larga y laboriosa gestión. Uno de los factores centrales de su éxito, fue su maestría como comunicador. Ahora no tenemos acceso a sus discursos. Pero escuchar a los poetas recitando es una buena alternativa. Especialmente a Neruda y Guillén»².

La realidad política que encontró Belaunde permanecía estancada. Las secuelas del proceso desencadenado a la caída de Leguía seguían vigentes. Con el partido político más gravitante proscrito, sus dirigentes presos o exiliados, las posibilidades del juego democrático estaban entrampadas. La falta de opciones alternativas al aprismo complicaba más el panorama y servía de pretexto para evitar elecciones legítimas. Además, los oficiales de mayor rango del Ejército tenían asumido, desde la independencia, la prerrogativa de poner de lado la Constitución y hacerse con el poder, cada vez que las circunstancias parecieran permitirlo y existiera la anuencia implícita de los sectores más poderosos. En ese escenario, quienes llegaban a la presidencia de la República — la mayor parte de las veces - lo hacían por carambola, esto es, por designación indirecta o por transacciones celebradas al margen del voto ciudadano.

El debate intelectual estaba animado de nueva vitalidad y matizado por varias tendencias. En los extremos, dos principales: hispanistas e indigenistas. Es decir, quienes propugnaban consolidar el modelo europeo impuesto durante los trescientos años del Virreinato y quienes aspiraban a una suerte de restauración del régimen precolombino, al que atribuían connotaciones socialistas. En la realidad, el Perú se había ido transformando en un país mucho más complejo y plural de lo que puede explicar cualquier esquematismo. Lo enriquecía la inclusión de nuevas etnias de inmigrantes y se había ido consolidando una realidad mestiza y distinta a todo lo anterior. Tanto las opciones pro autóctonas como las pro occidentales ofrecían visiones excluyentes, incapaces de reconciliar los diversos mati-

2 Esta y otras citas están sacadas de conversaciones grabadas entre Fernando Belaunde y Miguel Cruchaga en 1978. 
ces de la realidad. Además, el triunfo de la Revolución bolchevique había contaminado el debate político de una carga ideológica que respondía a diagnósticos originados en realidades muy remotas, principalmente europeas.

En 1993 Octavio Paz escribió: «La revolución de los caudillos de la independencia obedeció a la lógica de los imperios en desintegración; los caudillos escogieron, casi siempre con buena fe, la ideología más a la mano, la que estaba en boga en aquellos años [...]. Esas ideas democráticas no habían sido pensadas para la realidad hispanoamericana ni habían sido adaptadas a las necesidades y tradiciones de nuestros pueblos. Así comenzó el reinado de la inautenticidad y la mentira: fachadas democráticas y modernas y, tras ellas, realidades arcaicas. La historia se volvió un baile de máscaras [...]. Aquí aparece la gran hendidura: no había una relación orgánica entre esa ideología y la realidad hispanoamericana. Las ideas nuevas deben ser la expresión de las aspiraciones de la sociedad y, por tanto, deben ser pensadas y diseñadas para resolver sus problemas y responder a sus necesidades [...]. Lo que tuvimos fue la superposición de una ideología universal, la de la modernidad, impuesta sobre la cultura tradicional $»^{3}$.

Belaunde se había anticipado a ese pensamiento en 1956, propugnando, en su primera campaña presidencial, la idea del «Perú como doctrina». Esto es, la necesidad de buscar inspiración en «nuestra propia realidad». Para hacerlo, resultaba indispensable empezar por la experiencia local, haciendo que las propuestas se inspiraran en sus tradiciones en lugar de que se impusieran a ellas ideas venidas desde afuera. Por lo demás, una visión muy propia de arquitecto, quien trabaja a partir de dos hechos objetivos: el terreno y las necesidades de los usuarios. De esta manera de pensar provinieron programas como el de Cooperación Popular (inspirado en la minka y el ayni de la tradición andina), y otros como el Banco de Materiales (destinado a prestar y devolver materiales para la autoconstrucción, como en el clásico trueque de las ferias).

La primera campaña fue muy singular. Como todavía no se disponía de televisión, la manera de divulgar el mensaje se hacía en mítines realizados en cada barrio de las ciudades principales y en los pueblos apartados de las zonas rurales (recordemos que el Perú era todavía un país predominantemente agrícola). En un caso y otro, la llegada de la caravana que acompañaba a Belaunde era un acontecimiento festivo. El bullicio de la juventud que lo escoltaba y el ingenio de los recursos de los que se valían para despertar interés, debido a la predominancia juvenil entre los organizadores, dieron a los mítines un colorido de feria local. Cuando Belaunde llegaba, a hombros, como un torero triunfante, se producían en la concentración los movimientos de una marejada. Mientras su figura sonriente y

3 Cfr. Paz 1993. 
serena se acercaba lentamente al estrado — como en una procesión provinciana — sonaba una banda de músicos y reventaban cohetes y luces artificiales. Aplacado el bullicio inicial y concluido el canto del himno nacional, tomaba la palabra y empezaba el discurso.

La temática era siempre distinta, aunque su estructura bastante parecida. Empezaba con frases cortas y sonoras, como los latigazos con los que se pone en marcha una carreta de caballos: «Me dijeron que habían piratas en la costa y por eso he bajado de la serranía para enfrentarme con el peligro" o "¿Qué me aplaudes, pueblo peruano, si tú mismo has hablado por mis labios?». De inmediato, una carga de energía encendía a la multitud, que vibraba entusiasta con palabras como estas, pronunciadas en tono elegante, con voz redonda y sonora. Luego de algunos latigazos, entraba en materia; para ello modificaba ligeramente el tono, haciéndolo más sosegado y usando frases más largas. Aludía primero a las tradiciones mas importantes del lugar: una batalla, si la hubo; el recuerdo de algún momento de relevancia circunstancial (refugio de algún libertador o prócer, cuna de algún intelectual o artista renombrado). Otras veces, aludía al encanto urbanístico o a la tradición singular del sitio (recuerdo sus alusiones a episodios de la jarana criolla de "bajo el puente», en el mitin del Rímac, por ejemplo). Ennoblecía el lugar — que generalmente lucía muy pobre y descuidado—-, descubriendo su dignidad y señorío. Apoyado en esa introducción, formulaba propuestas programáticas, estableciendo la relación entre estas y la tradición. Lo hacía con conocimiento y lleno de contagiosa admiración por las calidades escondidas tras la pobreza aparente. En esta parte, sus discursos tenían sabor de travesía.

La trama tenía un recorrido que partía del pasado para proyectarse al futuro: de un futuro concebido a la altura de sus nobles tradiciones. El carácter de sus discursos tenía, por momentos, connotaciones de clase magistral. Después, cuando se aproximaba la hora de terminar, volvía a cambiar de tono y empezaba a sugerir — usando frases breves y poéticas - la realidad a la que se llegaría si se tomara el rumbo esbozado. De esta manera, insuflaba la fuerza necesaria para dejar a su auditorio cargado de ilusión. "Y si llego confiado al final de este proceso, que se inició turbiamente, no es porque tenga una desmesurada confianza en mí mismo, sino porque la tengo plena en Dios y porque siento que la Providencia no ha de desoír una voz que tan solo le pide luz para conducir a un pueblo a la justicia social», concluyó su discurso en la plaza San Martín, el 8 de junio de 1956.

Terminada la campaña, quedó consolidada la nueva alternativa política. Hacía falta estructurarla para convertirla en un partido estable. A ello se abocó Belaunde los años siguientes, trabajando y viajando intensamente por la institucionalización de Acción Popular. Tres años después, se convocó un congreso del partido, que debió realizarse en Arequipa. Situaciones coyunturales determinaron la suspensión de garantías y, como consecuencia, la desautorización de la reunión. Belaunde viajó secretamente al sur y fue apresado en la pampa de Vitor. Al tomar su declaración, el comisario le preguntó: 
«Diga si es verdad que lo encontraron disfrazado con un poncho». «El poncho no es un disfraz en el Perú —respondió-. Es el uniforme de las mayorías nacionales. Entiendo, sin embargo, que lo desprecien los hombres del gobierno, pues es la única prenda de vestir que carece de bolsillos».

Días después, al intentar abandonar a nado la isla de El Frontón, donde fue recluido, dejó unas líneas a los presos comunes, con los que había desarrollado mucha empatía. La carta terminaba con una frase edificante: «Dios siempre perdona y la patria siempre espera». La formidable vorágine iniciada en 1956 crecía en forma exponencial. El triunfo de la Revolución cubana, en 1959, distrajo a parte de la juventud hacia otras opciones que empezaron a aparecer ese mismo año. Pero Belaunde no cambió; siguió en la misma línea y compitió con Haya de la Torre, por primera vez, en las elecciones de 1962, treinta y un años después de la primera postulación presidencial del jefe del APRA. A partir de ese proceso, no ha vuelto a haber en el Perú ningún partido o candidato proscrito. La contribución de Belaunde a ese logro es innegable.

Inició su primer gobierno instituyendo las elecciones municipales. A partir del 28 de julio de 1963, el Perú tiene un régimen municipal elegido, que solo se interrumpió durante algunos años del régimen militar iniciado en octubre de 1968. Los municipios elegidos constituyen un aporte fundamental al robustecimiento institucional de la democracia peruana y empezaron el proceso de descentralización al que aspiraba el país desde mucho antes. En 1980, al iniciar su segundo gobierno, restauró la libertad de prensa que había sido conculcada mediante el secuestro de todos los medios informativos (televisión, radio y periódicos), por la dictadura de Velasco.

A pocas horas de ser desterrado a Argentina, recibió una llamada de José Luis Sert, un destacado arquitecto catalán, que ejercía el decanato de la Facultad de Arquitectura de Harvard. Lo invitaba a enseñar en Estados Unidos. De esa manera, Belaunde se reintegró a la enseñanza «solo por un año». Prefirió mantenerse como "profesor visitante» y cambiar de universidad anualmente, mientras durara el destierro, pues quiso «vivir con un pie en el estribo, listo para regresar al Perú en cualquier momento». Se repitió para él la época de los plazos elásticos de París. El destierro se prolongó esta vez, por otros nueve años. En esas circunstancias, contrajo matrimonio, en segundas nupcias, con Violeta Correa, que había sido una de sus colaboradoras más cercanas desde los primeros años de Acción Popular.

El destierro hizo que interrumpiera el contacto con sus principales fuentes de inspiración: las plazas públicas y la universidad peruana. Cuando regresó, en 1977, encontró un panorama muy cambiado. La improvisación y desmesura con las que se aplicaron las 
reformas las desprestigiaron y destruyeron buena parte del aparato productivo. El Estado se encontraba entrampado por la carga de infinidad de empresas públicas que daban un mal servicio y producían inmensas pérdidas. Añadido a ello, la crisis de la deuda externa y la aparición de una inflación crónica desplazaron de la agenda los temas del desarrollo, sustituyéndolos por necesidades de reordenamiento económico, derrota de la inflación y recuperación del producto bruto interno de la década de 1960.

Belaunde regresó al Perú con ánimo abierto y reconciliador. Obtuvo el respaldo mayoritario de las urnas en 1980 e inició su segundo periodo diecisiete años después de haber empezado el primero. Condujo al país por un nuevo quinquenio de desarrollo, en una época de transición en la que no había terminado de agotarse el modelo anterior (recién consagrado por la Constitución de 1979), ni cuajado uno nuevo, como el que precipitara la caída del Muro de Berlín, en 1989.

Impulsó la constitución del Frente Democrático, en respaldo de la candidatura presidencial de Mario Vargas Llosa, en 1990. Ejerció la función senatorial, hasta que el gobierno militarizado, instaurado en 1992, clausuró el Congreso. Intervino en la lucha por la restauración constitucional. Alentó la presidencia transitoria de su correligionario Valentín Paniagua y contribuyó significativamente con el éxito electoral de Alejandro Toledo en 2001. Ese mismo año falleció Violeta. El gran dolor de esa pérdida desencadenó su declinación. Lo visitaba con frecuencia en busca de un hilo que lo reconciliara con la vida. Uno de esos días le propuse reeditar El Arquitecto Peruano. Comprobé, por la reiteración de su interés, que había tocado una fibra sensible. Teniendo en cuenta que el principal valor de una revista antigua es su archivo historiográfico, pensé en instalarla en la red. Le mostré distintas maneras de hacerlo, valiéndome de una computadora portátil. Su entusiasmo fue creciendo. Me pidió que "prepare un papel para cederme los derechos». Pasaron los días y el proyecto avanzó lentamente.

$\mathrm{Al}$ amanecer del 24 de mayo, se supo que había tenido un derrame cerebral que lo dejó sin habla y limitado movimiento. El domingo 26, a eso de las cuatro y media de la tarde, acudí al hospital. Me recibió Carito. «¿Quieres despedirte de mi padre?», me preguntó. Asentí. Entré a la sala de cuidados intensivos, en la que existían varios cubículos independientes; casi todos divididos por cortinas. El primero, a la derecha, estaba cerrado entre paredes como un cuarto dentro de otro mayor. Belaunde estaba recostado en la cama, mirando fijamente un punto en el vacío. Una enfermera observaba desde un costado. Me acerqué a él por su lado derecho. Le cogí la mano; sentí lo que me pareció un ligero apretón. Busqué su mirada; seguía fija en el vacío. Me incliné, le conté al oído que venía del mar; que había pasado por la playa de Agua Dulce para traerle el rumor de las olas. Se volteó. Me miró fijamente y empezó a hacer trazos sobre la almohada. La enfermera 
miraba sorprendida. "Quiere decirle algo, señor». Le acerqué un papel y un plumón, y repitió los trazos. No se podían entender. Hicimos un segundo intento; nada. Otro más; inútil. Entendí que trataba de improvisar el texto pendiente. Le hablé al oído. No debía preocuparse, El Arquitecto Peruano volvería a aparecer de todas maneras. Levantó el brazo; me tomó de la espalda trayéndome hacia él. Me incliné dócilmente. Estuvimos abrazados en silencio, largo rato. Nos interrumpió la voz risueña de una de sus nietas. «iPapapa!», decía. Me aparté de la cama. Me miraba fijamente. Levantó suavemente la mano; se la llevó a la frente. Sin dejar de mirarme, se persignó. El barco estaba a punto de zarpar.

\section{Bibliografía}

KEYNES, John Maynard (1919). Las consecuencias económicas de la paz, capítulo 3.

PAZ, Octavio (1993). Itinerario, "América en singular y en plural», entrevista con Sergio Marras. 


\section{Luis Bedoya ReYes \\ (1919-)}

\section{LOURDES Flores Nano}



En febrero de 2009 cumplirá 90 años. Goza de un estado físico envidiable. Suele bromear cuando alguien lo halaga sobre el buen porte, pidiéndole al interlocutor —especialmente si es una dama- que mire tras las orejas para demostrar que no hay corte ni cicatriz que delate alguna «jalada reciente». Pero, esencialmente, goza de una extraordinaria lucidez que le permite discernir sobre la historia de la Humanidad, demostrando además que no en vano es doctor en la materia o sobre temas de profunda actualidad, como el inicio de la globalización y los problemas de la sociedad del siglo XXI .

Recientemente, invité a una joven e inteligente funcionaria municipal a un seminario sobre buenas prácticas municipales. Al concluir la exposición del ex alcalde de Lima, la citada funcionaria me mostró su admiración por el dominio de los temas de la administración local que exhibía el disertante Luis Bedoya Reyes, pero, sobre todo, por la actualización para abordar temas como el presupuesto participativo, preocupación cotidiana de autoridades y funcionarios edilicios.

Las referencias que anteceden tienen el propósito de comenzar estas líneas evidenciando la maravillosa vitalidad del personaje.

Esta obra, sin embargo, está destinada a rendir justo reconocimiento a ilustres peruanos y peruanas que durante el siglo XX han brindado contribuciones significativas al país. Podría decirse que es un trabajo colectivo destinado a destacar la trascendencia de algunos valiosos compatriotas.

Estas páginas podrían reportar varias del legado de Bedoya Reyes como peruano comprometido con el destino del país. Él está formado por tareas emprendidas en una determinada coyuntura, pero tienen valor extraordinario por su trascendencia.

Podría destacarse, por ejemplo, el significado que el corto paso por el Ministerio de Justicia supuso la reapertura de la Colonia Penal El Sepa. Es una importante experiencia penitenciaria que el país ha dejado abandonada y que constituyó y probablemente constituye una de las alternativas frente al inhumano hacinamiento de nuestros principales centros penales.

4 Véase sobre el particular el discurso al ser incorporado como miembro de número de la Academia Peruana de Derecho. 
Podría referirme a la Vía Expresa, al «Zanjón de Bedoya». Es una obra vial que después de cuarenta años no ha mostrado el deterioro que tantos pavimentos de vías urbanas y carreteras muestran a muy poco de sus inauguraciones. Al hacerlo, podría mostrarse la visión del alcalde metropolitano que se proyectó en la expansión de una ciudad que crecía vertiginosamente y para la que concibió su integración longitudinal.

Pero, siendo esas y otras obras importantes, juzgo que lo que más tributo rinde a este destacado político del siglo XX es haberse propuesto, en un país de tradición caudillista y de débil institucionalidad, forjar un partido político capaz de perdurar en el tiempo y procurar representar el pensamiento social cristiano en su aplicación concreta a la realidad del Perú.

He sostenido en otro lugar, con profunda convicción ${ }^{5}$ : «Aun con todas sus dificultades y particularmente las que nos han dividido en los últimos años, el Partido Popular Cristiano ha sido la expresión social cristiana más institucional del siglo. He sostenido líneas arriba, y así lo creo, que la institucionalización supone despersonalización. Es de justicia, sin embargo, ponerle nombre propio a la obra. Ese nombre es Luis Bedoya Reyes. Nuestro recuento de la presencia humanista en el siglo XX permite señalar tres grandes hitos: Víctor Andrés Belaunde, José Luis Bustamante y Rivero y Luis Bedoya Reyes. A este último ha de reconocérsele lo que sus predecesores no se impusieron como reto: la acción en un partido político organizado. Este en cambio fue un desafío que Bedoya abordó y que la historia reconocerá».

Pues bien, el presente trabajo procurará, de manera secuencial y ordenada en el tiempo, mostrar la importancia del significativo esfuerzo que significa construir un partido en el Perú.

Al hacerlo, seguiremos la siguiente secuencia:

a. La obra fundadora.

b. La perseverancia en las ideas.

- La fundación del Partido Popular Cristiano: un acto de consecuencia.

- El enfrentamiento contra la revolución militar por su errada orientación.

- La Asamblea Constituyente.

- La construcción democrática de la década de 1980.

- Las elecciones municipales de 1986: el espacio no aprista y no comunista.

- El Fredemo y la primacía de los intereses nacionales.

- La participación del Partido Popular Cristiano en el Congreso Constituyente Democrático de 1993.

- La figura señera.

c. La docencia permanente.

5 Cfr. Flores Nano 2000: 85. 
Quiero dejar constancia expresa que este trabajo constituye una aproximación absolutamente personal y, por ende, parcial y sesgada. Me excuso de antemano de no seguir con distancia y frialdad intelectual la vida de un maestro que ha guiado mis pasos y al que debo mi formación política.

\section{a. LA OBRA FUNDADORA}

En la década de 1950 un conjunto de jóvenes profesionales limeños y arequipeños, y algunas destacadas personalidades del mundo académico y profesional, decidieron la constitución del Partido Demócrata Cristiano.

La lista de las personalidades es reveladora de la calidad de iniciales adherentes a la plasmación en nuestra patria de una organización política inspirada en el pensamiento social de la Iglesia. Estuvieron entre los fundadores Honorio Delgado, Mario Alzamora Valdez, Enrique García Sayán, Enrique Cipriani, Javier Correa Elías, Ernesto Alayza Grundy, Luis Bedoya Reyes, Antonino Espinosa Laña, Roberto Pérez del Pozo, Alfonso Cobian, Héctor Cornejo Chávez, Mario Polar Ugarteche, Roberto Ramírez del Villar, Jaime Rey de Castro, Jorge Bolaños, Roger Cáceres Velásquez, Luis Giusti La Rosa, Grimaldo Luna Victoria y Carlos Callo, entre otros.

Para entonces, las encíclicas Rerum Novarum y Quadragessimo Anno llevaban seis y dos décadas de vigencia.

Las lucidas reflexiones sobre el Perú de Víctor Andrés Belaunde habían sido expuestas desde la primera década del siglo XX, se habían materializado en su polémica con Mariátegui en $\mathrm{La}$ realidad nacional y se habían concretado en su brillante participación en el Congreso de 1931.

Pero nada había sido más determinante que el llamado de José Luis Bustamante y Rivero a constituir una fuerza que constituyera un contrapeso a la única colectividad existente (el APRA) que lo había llevado al poder, pero que también lo había perturbado inclementemente durante su mandato.

Roberto Ramírez del Villar resume los orígenes del Partido Demócrata Cristiano: "Como sucedió en los albores de la República con los llamados 'autonomistas', dos grupos ideológicamente afines pero sin vinculación directa venían trabajando en Arequipa y en Lima con el mismo propósito. El capitalino con más acentuada preparación apologética, pero sin voluntad de acción, estaba reducido a un cenáculo académico; mientras que el provinciano agrupaba en su mayoría a gentes que desde 1933 habían participado vivamente en la lucha política. El impulso inicial, lógicamente, se produjo primero en Arequipa. Poco después tuvo lugar la fusión de ambos, naciendo de ella el Partido Demócrata Cristiano. Las elecciones de 1956 demostraron con la fuerza de los hechos las virtualidades de ambos sectores ${ }^{6}$.

6 Cfr. Ramírez del Villar 1964: 11. 
Bedoya Reyes refiere a su vez: "Coincidentemente conocíamos, por conversaciones, que en Arequipa, los amigos de don José Luis, así como núcleos juveniles estaban en el mismo esfuerzo. Si mal no me acuerdo, estaban tú [se refiere a Jaime Rey de Castro, autor del texto Testimonio de una generación: Los social cristianos], Ramírez del Villar, Héctor Cornejo — relacionados con el diario El Pueblo—, como también Jorge Bolaños y Roger Cáceres, mozos muy significativos en el movimiento universitario. Héctor me comentó que había la decisión de formar un movimiento político en Arequipa, que ya estaba constituido en su base inicial y que había adoptado el nombre de Movimiento Demócrata Cristiano, a propuesta de Ramírez del Villar. Sin embargo, había entre ustedes una situación de cierta perplejidad porque si bien es cierto que muchas de las personas que conocían a don José Luis y tenían con él una real afinidad, como eran los hombres nucleados fundamentalmente en el diario El Pueblo, los dirigentes universitarios tipo Bolaños o Roger Cáceres no tenían necesariamente coincidencia con los hombres del diario El Pueblo y había un cierto cuestionamiento desde el punto de vista que podríamos llamar la real identificación con los principios. Se plantea entonces en Arequipa algo muy parecido a lo que estábamos viviendo en Lima; y recuerdo que, en esa misma noche de la reunión, cuando nosotros insistimos que también en Lima debía llamarse Movimiento Demócrata Cristiano en vez de ser un movimiento en torno a la persona de don José Luis, recibimos el respaldo de don Honorio Delgado y otras personalidades» ${ }^{7}$.

Resultaba indispensable concretar la organización de un partido democrático que, inspirado en las ideas de la democracia cristiana y hermanado con instituciones similares de Europa y América Latina, aplicara esas tesis a la realidad concreta del Perú.

Bedoya Reyes fue uno de sus gestores. No en vano fue elegido el primer secretario general de la organización.

Destaco este hito porque estimo que la formación del Partido Demócrata Cristiano tuvo, respecto de otras instituciones nacidas antes o en forma coetánea, algunos rasgos diferenciales:

a. Nació como sus similares en el mundo, como una organización formada para la defensa y promoción de un pensamiento.

b. Los fundadores no reclamaban para sí la autoría del pensamiento. Este se inspira en la enseñanza social de la Iglesia y tiene carácter universal.

c. Si bien el núcleo fundador fue de primer nivel y de una calidad de liderazgo indiscutible, la organización no se sustentó en la conducción carismática de un caudillo.

7 Cfr. Bedoya Reyes 1985: 139. 
No era esfuerzo menor el desplegado por esta generación. La historia republicana del Perú, a ciento treinta años de la independencia, se había sustentado en las disputas de los caudillos militares y civiles del siglo XIX; en las figuras representativas de la Republica Aristocrática o, en la personalización de algunos esfuerzos democráticos y autoritarios.

Solo Mariátegui y Haya de la Torre habían forjado partidos inspirados en un pensamiento. Ambos, sin embargo, se reclamaban autores del mismo, resaltando su única aplicación a la realidad nacional («sin calco ni copia», «el espacio tiempo histórico»).

El Partido Demócrata Cristiano surgió en cambio para darle estructura política a un pensamiento que los fundadores no definían como de su inspiración, sino que se sustentaba en ideas de carácter universal, inspiradas en la antropología cristiana y en el análisis social de la realidad que la Iglesia promovió desde finales del siglo XIX frente a la industrialización y el capitalismo.

Por eso, Bustamante y Rivero saludó la formación del Partido Demócrata Cristiano: "Yo veo en ella el símbolo de dos prometedoras esperanzas: un renacer pujante de nuestro espíritu democrático y una elevación auspiciosa de los índices morales de nuestra colectividad política bajo la inspiración de los principios de la sociología cristiana, que es como decir de los principios de la civilización occidental. Con la fundación del partido habéis cumplido por eso, una misión ejemplar: la de crear una escuela de docencia política para las nuevas generaciones ciudadanas» ${ }^{8}$.

\section{b. LA PERSEVERANCIA EN LAS IDEAS}

Si en las líneas que antecede he resaltado la importancia de dotar de contenido político y de fundar una organización inspirada en ideas, quisiera ahora resaltar el valor que tiene una trayectoria sustentada en el seguimiento invariable de las mismas.

Porque mi tesis, que el mayor legado de Bedoya Reyes es la formación de un partido político doctrinario y no caudillista, solo tiene contenido si se logra demostrar una línea de conducta consecuente con esa voluntad y una actitud personal hacia ese propósito. Eso es lo que en mi concepto justifica la incorporación de Bedoya Reyes en la presente obra: la consecuencia con sus ideales y la identidad entre ellos y su conducta por más de medio siglo.

\section{- La fundación del Partido Popular Cristiano: un acto de consecuencia}

Fue sin duda doloroso para algunos de los fundadores de la Democracia Cristiana apartarse de sus filas solo diez años después de la gesta fundacional.

8 Cfr. Bustamante y Rivero s. f.: 65-66. 
El tiempo — que es siempre el que permite evaluar la verdad o no de la intención expresada - permite afirmar que lo expresado en la Declaración Constitutiva del Partido Popular Cristiano en 1966 ha tenido un correlato de vida: «Declaramos que estamos vitalmente identificados con los principios y postulados demócrata cristianos, que constituyen el patrimonio al que no renunciamos y que reivindicamos en su totalidad. Creemos en la dignidad de la persona humana y en su derecho a la libertad; en las virtualidades de la democracia como sistema de gobierno; en la tolerancia y el diálogo fraterno como medio de relación; en la necesidad de combatir tenazmente la justicia social superando las luchas de clases y la violencia en cualquiera de sus formas; en la urgencia de lograr con realismo los cambios estructurales e institucionales que el país precisa para su redención; y en la afirmación de una política que concentre sus esfuerzos en la justa distribución de la riqueza».

En cuarenta años, nadie puede imputar a Bedoya Reyes y a los fundadores del Partido Popular Cristiano haberse apartado del pensamiento que organizaron políticamente.

En cambio, puede afirmarse que hubo un profundo error histórico:

- Al considerar la Democracia Cristiana que se servía al ideal social cristiano si se avalaban las reformas estructurales en las que el partido había inspirado su propuesta, aun a costa de la democracia.

- Al suponer que el velascato con su preconizado humanismo podía ser el articulador de la reforma social cristiana. El colectivismo, el estatismo y el fracasado socialismo de la revolución militar no merecían respaldo, sino cerrada crítica.

Por eso, sostengo que el alejamiento de la Democracia Cristiana y la formación del Partido Popular Cristiano fue un acto de consecuencia y lealtad al pensamiento y a los valores en que habría de inspirarse la conducta política.

\section{- El enfrentamiento contra la revolución militar por su errada orientación.}

Siempre con la perspectiva que da el tiempo, puede sostenerse el acierto y el valor que tuvieron los líderes pepecitas al enfrentar las tesis del velascato y las preconizadas reformas estructurales.

Con acierto se sostuvo:

a. Que no se transformaría la vida del agricultor y el campesino en un simple reparto colectivista de la tierra, quitándole además todo valor al colocarla como bien indisponible.

b. Que no se transformaría el aparato productivo del país, estatizando las actividades fundamentales y pretendiendo generar empresas estatales eficientes. 
c. Que no se produciría empleo y riqueza encerrándonos en nosotros mismos, prohibiendo mirar al mundo y alegando un nacionalismo exacerbado.

d. Que no se transformaría al peruano con una educación socializante y con una prensa bajo control dictatorial, pues solo la libertad hace crecer al ser humano y realizarse plenamente.

Que, en resumen, el camino de éxito del Perú y la posibilidad de alcanzar niveles de vida más promisorios no pasaban por privarnos de iniciativa, de propiedad y de libertad. La transformación social genuina de nuestra patria, que resultaba fundamental para acabar con un país oligárquico y excluyente, suponía educar masivamente y con calidad; generar trabajo y expandirlo; abrirnos al mundo y exportar; generar riqueza y distribuirla.

Hubo claridad de ideas y consecuencia al sostenerlas, en un mundo cuya juventud vivía entusiasmada con los ecos de Mayo del 68, en París, y los revolucionarios de Sierra Maestra, cuya fuerza amada se inspiraba en el nacionalismo nasserista, cuyos referentes en el poder eran gobiernos socialistas o dictaduras militares.

Bedoya Reyes, Alayza, Polar, Ramírez del Villar y Espinosa no hablaron a oídos abiertos a la libertad, sino a mentes entusiasmadas con la moda "progre» de entonces. Sería injusto no reconocer que el Perú después de la década de 1970 se abrió a una forma diferente de convivencia, más horizontal y democrática, pero el Gobierno Revolucionario de las Fuerzas Armadas fue, en términos de proyecto político, económico y social, un clamoroso fracaso. Mi generación ha sufrido las consecuencias de ese desastre. Quienes lo enfrentaron con coraje y claridad mental tuvieron toda la razón.

\section{- La Asamblea Constituyente}

Momento estelar de la obra de Bedoya Reyes fue su actuación en la Asamblea Constituyente.

Si la política está hecha de gestos, uno debería ser destacado con la importancia histórica de haber abierto el camino hacia una transición ordenada. La renuncia de Bedoya Reyes a la Presidencia de la Asamblea Constituyente que los grupos marxistas le propusieron para respaldar a Haya de la Torre fue mucho más que gesto de nobleza política. Fue el establecimiento de una ruta para la viabilidad de la Asamblea y para permitir la redacción de una Constitución que sirviera de puente para reencausar al Perú a la democracia.

Bedoya Reyes define su rol en la Asamblea Constituyente como uno de coordinación. En realidad, fue el líder de una bancada parlamentaria cuyo aporte constitucional no es nada desdeñable: 
a. La incorporación de una norma de apertura reconociendo la dignidad de la persona humana y su preeminencia frente al Estado y la sociedad.

b. La consagración de principios fundamentales a favor de la libertad y de la propiedad privada.

c. La incorporación del régimen económico de la economía social de mercado.

d. El establecimiento de un presidencialismo moderado y la diferenciación de funciones de las Cámaras legislativas.

e. La regulación de mecanismos frente a la crisis constitucional, como la disolución de la Cámara de Diputados.

En el aporte del Partido Popular Cristiano en la obra constitucional de 1979 se ven reflejados los principios que inspiran a la colectividad. Muchos de esos aportes, negados por los detractores de entonces, son asumidos y hasta dotados de contenido propio por quienes denostaron de ellos. Uno de los casos más significativos es el concepto de la economía social de mercado, que hoy «tirios y troyanos» defienden y hasta proponen como modelo económico de su inspiración.

\section{- La construcción democrática de la década de 1980}

Recuperada la democracia, Bedoya Reyes aceptó el llamado de Belaunde para la colaboración ministerial. Primero y a cambio de nada fueron los seis votos del Senado que le otorgaban la mayoría de la que carecía. Luego, vino la colaboración. Ella se sustentó en el aporte del Partido Popular Cristiano de ministros notables para apoyar el programa del presidente Belaunde.

En la mente de los fundadores del Partido Popular Cristiano estaban los duros años de la hegemonía de la coalición parlamentaria APRA-UNO, constituida para perturbar la marcha reformista de la alianza AP-DC. Había que darle estabilidad democrática al gobierno elegido y el Partido Popular Cristiano lo hizo con lealtad y consecuencia.

Dicha lealtad no eximió al Partido Popular Cristiano de expresar sus puntos de vista, concordantes con las propuestas de profundo y rápido cambio que Bedoya había propuesto en la campaña electoral. Porque la diferencia central entre la propuesta del segundo belaundismo y la plataforma pepecista radicaba esencialmente en la urgencia - no compartida por Acción Popular - de revertir las denominadas «reformas estructurales» y el estatismo heredado con prontitud y radicalidad. No obstante estas perspectivas diferentes, la conducta del Partido Popular Cristiano y en particular el liderazgo de Bedoya Reyes fueron de una extraordinaria lealtad a la palabra empeñada. 
Hubiéramos esperado que el presidente Belaunde respondiera a esa conducta con su respaldo al líder social cristiano en su postulación de 1985. El presidente Belaunde no correspondió con grandeza, prefirió impulsar la candidatura propia.

Derrotado por Alan García en 1985, Bedoya Reyes lideró la línea opositora que el Partido Popular Cristiano trazó. Una vez más, se tuvo lucidez para advertir que mecanismos ficticios de crecimiento, que muchos aplaudieron y aprovecharon, no constituían formas sanas de manejo económico y que el precio más temprano que tarde se pagaría.

Naturalmente, no se dudó en enfrentar la hiperinflación que trajo el deterioro clamoroso de la moneda, el aislamiento internacional por la decisión unilateral de no pagar la deuda externa, los mecanismos fraudulentos para favorecer a determinadas empresas nacionales y extranjeras; las execrables matanzas en los penales de El Frontón y Lurigancho; las injustificadas fortunas personales labradas desde el poder y, por supuesto, el irracional intento de estatizar la banca.

\section{- Las elecciones municipales de 1986: el espacio no aprista y no comunista}

Pero si algún momento marcó el temple de la hora fue el llamado que en 1986 hizo Bedoya Reyes a no permanecer como «borregos» frente a la anunciada pretensión aprista de permanecer en el poder.

Mucho más que los anuncios de Wilfredo Huayta ${ }^{9}$, las veleidades reeleccionistas que contenía el proyecto Marisca ${ }^{10} \mathrm{o}$ los diálogos desde el balcón presidencial de García hacia el balcón municipal de Barrantes era la tendencia latinoamericana de impulsar una coalición entre el socialismo y el comunismo para proyectos gubernamentales de larga envergadura. Ello, sumado a los triunfos socialistas europeos, mostraba un mundo político que pintado de rosado y rojo dejaba poco espacio a otras fuerzas.

Las elecciones municipales de 1986 en Lima fueron la ocasión en la que Bedoya Reyes propuso reabrir, y logró hacerlo, el espacio no aprista y no comunista que parecía irremediablemente perdido.

El triunfo en aquella elección lo hubiera consagrado en su camino a la presidencia de la República en 1990. Hubo artimaña desde Palacio y estafa electoral cuando se anunció un tren eléctrico que veinte años después aún no camina. Se desplazó de la punta al can-

9 Ministro de Energía y Minas que anunció que el APRA había tardado sesenta años en llegar al poder y que permanecería cincuenta años en él.

10 El diputado Marisca había sido elegido en la filas de la Convergencia Democrática que Bedoya Reyes encabezó, pero pronto viró hacia el APRA y sirvió de impulsor del proyecto de ley sobre la reelección del presidente García. 
didato Bedoya, que hubiera constituido un líder democrático alternativo fundamental en tiempos del desborde alanista y del caos nacional.

\section{- El Fredemo y la primacía de los intereses nacionales}

Bedoya Reyes no pudo encarnar el liderazgo alternativo ante el fracaso aprista en el gobierno y ante el clamoroso avance de la subversión. Sin embargo, tuvo una vez más inmensa generosidad para endosar su respaldo a Mario Vargas Llosa y para conducir al Partido Popular Cristiano a integrar el Frente Democrático.

Con Mario Vargas Llosa a la cabeza, se propuso una auténtica transformación económica frente a la dramática crisis que el gobierno aprista legaba.

\section{- La participación del Partido Popular Cristiano en el Congreso Constituyente Democrático de 1993}

Derrotado Vargas Llosa por Alberto Fujimori, los pepecistas — bajo el liderazgo de Bedoya Reyes - trazamos una línea consecuente con nuestra visión de las urgencias del Perú.

Conocí de la serenidad y experiencia de Bedoya Reyes analizando con profundidad los procesos de investigación y acusación que afectaron al ex presidente García, definiendo las posiciones a asumir frente a la contrarreforma impulsada por el nuevo gobierno y las urgencias para enfrentar la subversión; y simultáneamente frente a los primeros indicios del autoritarismo.

En diciembre de 1991, el propio Bedoya Reyes fue testigo del público reconocimiento que el ex presidente Fujimori hizo de sus simpatías y voto hacia él, graficadas en la expresión "que su corazón era del PPC»" ${ }^{11}$.

Ante el enfrentamiento de poderes, Bedoya Reyes secundó los llamados al diálogo que propiciaba el presidente del Senado, Felipe Osterling.

Los momentos más álgidos se produjeron luego del golpe de Estado del 5 de abril. La condena fue inmediata y sin justificaciones.

Donde Bedoya Reyes marcó distancia con parte de la oposición y generó controversia interna, fue ante la convocatoria al llamado al Congreso Constituyente, efectuado tras la Asamblea de la Organización de los Estados Americanos en Bahamas. Voces internas, como las de Ramírez del Villar y Borea, cuestionaban acremente esta participación calificándola de una "legitimación de la dictadura». La mayor parte de partidos de la oposición se inclinaban por la tesis abstencionista. Bedoya Reyes se empeñó en alentar la participación y condujo al Partido Popular Cristiano, con el respaldo de un grupo de nosotros, al denominado Congreso Constituyente Democrático. Primó su convicción que había

11 Palabras pronunciadas por el veinticinco aniversario del Partido Popular Cristiano. 
que ofrecerle al país una salida, aunque estrecha y cuestionable, para evitar el aislamiento internacional y la condena internacional al Perú.

Los años del fujimorismo fueron una dura prueba para los partidos políticos, pues, una vez más en nuestra historia, se denostó de ellos y se procuró su desaparición. Internamente, el partido se vio afectado por voces contrapropuestas que se apartaron de nuestras filas, alegando unos claudicación democrática y otros obstrucción e incomprensión a un gobierno «que llevaba a la práctica nuestras ideas».

Puedo dar fe, de mis innumerables diálogos, que Bedoya Reyes actuó siempre con enorme consecuencia y que con su presencia y ejemplo presidiendo cada semana una raleada comisión política nos enseñó que, cuando se tienen ideales, solo hay un camino: perseverar.

\section{- La figura señera}

En muchos discursos Bedoya Reyes nos ha repetido que la diferencia entre los jóvenes y las personas adultas está en una letra. Mientras a los jóvenes les corresponde «saber llegar», a los mayores les toca «saber legar».

Pocos líderes políticos han sido capaces, en el Perú y en el mundo, de cumplir este ultimo postulado: «saber legar».

Los pepecistas podemos dar fe que la personal convicción de nuestro fundador por la construcción de una organización trascendente lo llevó a dejar la presidencia del partido y confiar sus destinos a nuestra generación. Ello no lo ha excluido del consejo permanente y de ser la figura que indiscutiblemente más adhesión, admiración y seguimiento genera.

Pero el presidente fundador del Partido Popular Cristiano supo legar, porque esa ha sido una contribución decisiva a la consolidación definitiva de una organización no caudillista.

Espero que en algunas décadas, cuando otros den cuenta de lo que hicimos y de lo que harán los que vienen, se concluya que el legado fue administrado para que perdure en la historia, como fue el encargo del fundador.

\section{LA DOCENCIA PERMANENTE}

Considero que la distancia de la política cotidiana, el estilo personal y la experiencia que transmite han permitido adquirir al doctor Bedoya Reyes una dimensión que pocos políticos pueden exhibir. Su palabra es hoy valorada y respetada por adherentes de siempre, pero también por contrincantes de antaño.

Debo concluir señalando que lo más destacable del presente es que Luis Bedoya Reyes, sigue dando cátedra en cada diálogo, en cada exposición, en cada presentación pública. 
Enseña con la sencillez de quien sabe bien lo mucho que tiene que aportar y con la serenidad de quien puede responder con tranquilidad al severo juicio con el que se mide la consecuencia entre lo predicado y lo vivido.

\section{Bibliografía}

BEDOYA REYES, Luis y otros (1985). Testimonio de una generación: los social cristianos. Lima: Centro de Investigación de la Universidad del Pacífico.

BUSTAMANTE Y RIVERO, José Luis (s. f.). El mensaje civico de José Luis Bustamante y Rivero. Lima: Fundación M. J. Bustamante de la Fuente e Instituto del Sur.

FLORES NANO, Lourdes (2000). El evangelio y la tierra, tomo I. Lima: J. L. Disegraphic.

RAMÍREZ DEL VILLAR, Roberto (1964). «El Partido Demócrata Cristiano». En: revista La Revista Parlamentaria, nro. 1, julio (segunda época). 


\section{Fernando de Szyszlo \\ (1925- )}

Mariella Balbi 

El encargo que me han dado — escribir un ensayo sobre Fernando de Szyszlo— resulta siendo palabras mayores. Y lo digo por varias razones, el término ensayo me suena solemne y nuestro pintor no lo es, quien esto escribe tampoco. No soy experta en el género, nunca lo he sido. Entonces viene de inmediato la duda sobre cómo resultará este desempeño. Aunque el asunto del espacio no es una limitación, el problema se plantea cuando, al acercarme a la persona de carne y hueso, uno se pregunta cómo presentarle al lector a un artista tan polifacético, con tanta experiencia acumulada, culto, vital, comprometido, además de simpático y otras virtudes. Todo ello sin caer en el panegírico que ciertamente a él no le gustaría y a mí tampoco.

Habiendo ya comenzado a abordar esta difícil tarea surge otro dilema: qué presentar en un ensayo, ¿la obra o el hombre? Si uno se vuelve ecléctica y decide por ambos, aparece nuevamente la duda sobre la prelación. Finalmente, al no ser crítica de arte ni querer serlo, sino solo una contempladora de lo bello, tendrá que conformarse el lector con mi peculiar — probablemente limitada — percepción de uno de los mejores pintores nacionales y latinoamericanos del siglo XX y del XXI.

Indudablemente, si se trata de un extraordinario pintor, lo más lógico sería reflexionar primero sobre su arte y su búsqueda a través de este. Hace un tiempo escribí un libro sobre Szyszlo, intrigada por su manera íntegra de asumir la vida. Fue una conversación larga que buscó dar a conocer —a quien quisiera aproximársele — a este personaje fundamental para la cultura peruana. Es el libro que más placer me ha dado y el más estético. No tanto por mi trabajo, sino porque Szyszlo mostró su versatilidad e hizo gala de su capacidad de reflexión. Descubrí y aprendí mucho, me divertí bastante (cosa que para mí es fundamental); la edición se lee de cabo a rabo y —lo más importante— el lector queda regocijado con la vida.

Entonces, volviendo al reino de lo lógico, cuando le pregunté a Szyszlo: ¿qué debería ver una persona que se detiene ante un cuadro suyo? Él contestó, con la sencillez que lo caracteriza: «La mejor manera para mirar mi pintura, en realidad cualquier pintura, es no tener prejuicios, no creer que vas a comprender; no hay nada que comprender». Agregó que la pintura abstracta o una figurativa (la representación de un paisaje, de personajes) puede igualmente conmover al espectador y que esa capacidad de conmover depende «no de lo que se representa, sino de cómo se representa». 
Más claro ni el agua. Esta es una de las cosas que más sorprende de Szyszlo: su capacidad para transmitir conceptos fundamentales de manera prístina; aderezándolos con anécdotas ilustrativas que permiten asimilarlos. Como la del diálogo del genial Matisse (pintor francés de las primeras décadas del siglo XX) con una admiradora y que viene a cuento de qué y cómo mirar: «Maestro — dijo la dama—, no comprendo sus cuadros». El pintor le respondió: «Señora, ¿̨a usted le gustan las ostras?». «Sí, claro», respondió ella. Matisse retrucó: «¿Comprende usted a las ostras?».

Detrás de los bellos colores, de las innovadoras formas, de su propuesta pictórica tenemos a una persona valiente que empeñó todo para ser pintor. Esa fuerza, ese coraje se transmiten plenamente en su obra llena de tensiones, de las que el observador no puede escapar. Tal vez se piense que estoy idealizando en demasía, pocos saben sin embargo que la firme presencia de Szyszlo en la plástica le costó bastante. Imagine a un adolescente embarcado en seguir la carrera de Arquitectura con la complacencia que el entorno siempre tiene ante una carrera digamos «normal». Para perfeccionar su dibujo, que no era muy fluido, toma clases en una escuela de arte y ahí es donde se produce una revelación trascendental. Szyszlo lo llama su «camino a Damasco». El rayo de San Pablo, el apóstol, le indicó con certeza que la pintura era lo suyo y lo describe así: «¿Cómo decirte? (Era) el descubrimiento, el balbucear de un lenguaje con el que algún día podría expresarme, comunicarme». Y así fue, pero se trató de un camino largo. Quien cuenta con el don de pintar se compara con sus pares. ¿Cómo saber que uno tiene talento y cuán importante es sobresalir, en suma, triunfar? Los artistas triunfan o no tienen éxito, esas son sus reglas. Quienes no lo somos, estamos algo más ajenos a ese tremebundo dilema. Añadamos a la escena la visión (que no ha cambiado mucho) de que un artista es un bohemio, tarambana y, por supuesto, está condenado a la pobreza.

En sus inicios Szyszlo pasó un periodo largo sin vivir de su pintura, el arcano de un artista. La fascinación y la certeza fueron sus aliados. «Puedes ser mal pintor pero vender, —nos dijo con sapiencia y añadió lo que le comentaba a sus alumnos—: Hay cuatro tipos de pintores: pintores buenos que venden, pintores buenos que no venden, pintores malos que venden y pintores malos que no venden. Por el éxito económico no puedes medir la calidad de la pintura». El reconocimiento duró en llegar pero llegó con fuerza y ese paréntesis le sirvió para encontrar su lenguaje, su palabra pintada y definir sus opciones, sin flaquear. Con franqueza nos contó en aquella ocasión: «Hasta el día de hoy me parece un milagro que yo pueda vivir de mi pintura. Te voy a decir una cosa que puede verse como vanidosa: nunca he pedido hacer una exposición, ni cuando tenía veinte años. Siempre he tenido la paciencia de esperar».

En una exposición de Szyszlo se encuentra siempre un público joven, algunos son estudiantes de la Escuela de Bellas Artes de Lima, otros seguramente ya son pintores en ejercicio. De lejos uno puede observar la admiración que le tienen, él es un referente 
para quienes se inician en este oficio. Ciertamente no lo ven como alguien a quien copiar, se trata más bien de una propuesta, de un planteamiento con el cual se identifican. Aprecian que haya rescatado con sus pinceles ese complejo espacio llamado cultura peruana. A su manera Szyszlo es un líder, pues fue el primero en resaltar la plástica precolombina, nutriéndose de esta. No por un afán chauvinista o patriotero, sino por una admiración hacia el denominado arte primitivo y donde nuestros antepasados prehispánicos destacan con la belleza y simplicidad de sus creaciones.

Ojo que, cuando su vocación aparece, esa cultura deslumbrante era ajena a buena parte del Perú. Los huacos se veían como algo extraño, distante y causaban bastante rechazo en la clase supuestamente culta. Sabido es que el estilo de Szyszlo se inscribe en el lenguaje abstracto, pero condensa sutilmente ese rico mundo precolombino e incluye a la misteriosa y minimalista costa peruana, particularmente Paracas, ese lugar del Perú que parece estar fuera del mundo. Cuando niño, nuestro pintor pasaba ahí sus vacaciones, entre mar, arena e historia. Todo ello quedó en la memoria y luego pasó a sus lienzos.

Me dijeron que esta edición está destinada a lectores jóvenes, con la enorme gama de posibilidades que tiene la juventud. Releyendo lo escrito hasta aquí, vuelve la hesitación: ¿̨le importará todo esto a un adulto menor, le será relevante? Aunque la pregunta más complicada se refiere a si estaré transmitiendo acertadamente lo que es una gran obra y un gran pintor. Debo aclarar entonces que el imaginario de Szyszlo no se limita a lo mencionado. También está su profunda admiración por nuestra historia, tanto así que al primer cuadro de su primera (segunda en realidad) exposición lo llamó Cajamar$c a$, en recuerdo de la ejecución del inca Atahualpa.

Entre los pintores nacionales, ninguno se ha inspirado en Atahualpa, menos en su muerte. La exposición que mencionamos ocurrió en Washington en 1962, cuando Szyszlo tenía un trabajo en la Organización de los Estados Americanos relacionado con su oficio pero lejano a los pinceles. Pintaba de noche y de día era "oficinista». La serie de cuadros se basó en un poema quechua traducido por el escritor José María Arguedas: «Apu Inka Atawallpaman» («La muerte del inca Atahualpa»). Nuestro artista quedó prendado por la fuerza del texto: «Q $Q$ ué arco iris es este negro arco iris que hoy se levanta!!, que maldice la muerte del soberano. Otras líneas del poema quechua inspiran más cuadros; sentencias tremendas como «mi corazón presentía» o «sus dientes crujidores ya estarán mordiendo la bárbara tristeza» se convirtieron en colores y texturas.

Hace un tiempo entrevisté a un excelente tejedor ayacuchano, Eddie Sulca, el primero en llevar lo tridimensional a los tapices. Al preguntarle por los artistas a los que admiraba respondió sin dudarlo: «Definitivamente a Szyszlo. Él tiene su lugar, sus colores son fuertes y sus diseños abstractos y complicados, eso me gusta. Cuando me ha explicado su obra la he comprendido mejor, me parece muy real y lo siento cercano». 
Pese a que su cercanía con el país está inscrita siempre en su pintura, pese a su fuerte amistad con José María Arguedas, símbolo del indigenismo, a Szyszlo esta corriente artística no lo inspira, aunque pondera su valor.

$\mathrm{El}$ indigenismo fue una corriente renovadora en el mundo de las ideas nacionales. En una sociedad sumamente vertical, racista hasta el extremo, nadie representaba lo relacionado con lo andino. Szyszlo considera que tenía un lado bueno y otro no tanto: «era una reacción a lo académico... pintaban cosas que a la gente no le gustaba, que no eran fotográficamente descriptivas... Lo malo era que consideraban que para hacer pintura peruana había que pintar temas peruanos, rostros indígenas y eso no es hacer pintura peruana. Odría tenía un pintor favorito, un extranjero, se llamaba Krecovik, pintaba al inca Atahualpa y esos temas».

Para alguien siempre vanguardista, sin duda el indigenismo podía resultar asfixiante y muy probablemente parametrado. Szyszlo no quería repetir los cánones del impresionismo, ni imitar al cubismo, aunque Picasso influenció su pintura en el periodo inicial. Él estaba abierto al mundo, a los cambios, al arte contemporáneo. Ciertamente su estadía en París, en 1949, fue fundamental, por la riqueza cultural que tiene la Ciudad Luz y por la época en la que le tocó vivir. Todo bullía, la modernidad estaba en gestación. Contemplar un Rembrandt —uno de sus preferidos—, un Tiziano, detenerse en ellos, analizarlos, tener amistad con Octavio Paz, Matta, Lam o Tamayo, con Cortázar, impregnarse del revolucionario pensamiento surrealista, conocer a Breton fueron experiencias enriquecedoras y deslumbrantes a pesar de las limitaciones económicas.

«En París — relata Szyszlo— viví el deslumbramiento por una nueva pintura, aprendí a hablar en el nuevo lenguaje de la nueva pintura abstracta que había allá, eso que llaman la abstracción lírica, lo contrario de la geométrica, donde había ido la abstracción en general. Me olvidé por unos meses del tema precolombino, quedaron vagos atisbos todo el tiempo. Hasta que me fui a Washington, en 1958, lo había dejado de lado». La provechosa estadía en el París de la postguerra duró cinco años.

Los títulos de los cuadros de Szyszlo nos anuncian sus inclinaciones y desde el inicio delinean el camino que continúa hasta hoy. Siempre su país, lo precolombino, además de sus demonios y ángeles. Pero él se siente también profundamente latino. De hecho uno de sus íconos o "padres» — como gusta llamarlos— es el mexicano Rufino Tamayo, a quien frecuentó. Gracias a sus dones, Szyszlo logró significar, interpretar lo latinoamericano. Es uno de los pocos pintores peruanos que trasciende sus fronteras y se inscribe en esa plástica. Como él dice: «Es que ser latinoamericano es tan complicado, porque somos frutos de corrientes diversas... Si eres un poeta francés sabes horrores de poesía francesa, si eres inglés lo mismo. Pero si eres un poeta latinoamericano has leído a los ingleses, franceses, italianos, japoneses y también latinoamericanos. Westphalen u Octavio Paz son los ejemplos exactos de lo que es un latinoamericano, aplastados por todo 
esto, mirando desde lejos, sentados en la mesa donde se sientan los primos pobres, sin compartir el banquete. ¡Esa es la fuerza del arte latinoamericano, esa es la posibilidad!».

Volviendo a lo ilustrativo de los nombres de sus cuadros y sin ánimo de establecer una cronología en esta aproximación —imposible en realidad—, notaremos que los de la primera etapa se centran en la mirada tan especial y sentimental que Szyszlo tiene de lo que podríamos llamar lo quechua (si a alguien esto le parece arbitrario — seguramente lo es—, que no lo tome en cuenta): Cajamarca, Sol negro, Waman Wasi (casa del halcón), Puka Wamani (halcón rojo), Ejecución de Túpac Amaru, Paisaje ritual de Machu Picchu. Otros lienzos nos llevan al paisaje costero del sur: Mar de Lurín, Camino a Mendieta (playa de Paracas), Noche estrellada, pero están en interacción con los habitantes de su mundo interior, sin soslayarlos: Visitante de la noche, Anábasis (poema de Saint-John Perse), Cuarto de paso, Cámara ritual, El innombrable, Mesa ritual, Pasajero, Recinto, Travesía, Abolición de la muerte.

Debo insistir que no hay un orden cronológico, porque Szyszlo sigue echando mano a muchos de estos nombres hasta el día de hoy y con razón, porque constituye una suerte de breviario de su interioridad, de sus estados de ánimo. Cuando le transmití que una de las críticas a su trabajo apuntaba a que era repetitivo y que había Camino a Mendieta I, II y hasta III, o varios cuadros con el mismo nombre, él —siempre agudo-respondió: «Soy el primero en afirmarlo (que es repetitivo). Siempre he dicho que mi pintura se puede caracterizar por ese refrán francés que sostiene: plus ça change, plus c'est la même chose (más cambia, más es lo mismo). Si ves un cuadro mío, te darás cuenta de que no es igual a los actuales. El alfabeto es el mismo, pero la forma no y las intenciones tampoco». Y es absolutamente cierto.

Aunque estamos frente a un intelectual formidable, no hay nada de racional en su pintura. Szyszlo es un romántico que convive con emociones intensas, amores, angustias, fantasmas, con una compleja relación con la muerte y el lienzo es el espacio donde esto se expresa; por eso quien mira sus cuadros verá una cierta inclinación por lo arquitectónico. Pero la tensión y el misterio de los que hablábamos líneas arriba —ojalá lo recuerde el amigo lector - nunca están ausentes. ¿Qué los provoca? Mi ignorante percepción es que los colores tan intensos que usa Szyszlo son uno de los elementos. Cosa curiosa, él los emplea para acentuar la relación entre la sombra y la luz. El claroscuro es su certeza o como señala: «Yo vengo de la tradición del claroscuro — y añade—, el color viene después... En realidad..., no tiene importancia».

Y para continuar en esta dialéctica tan personal que es la pintura de Szyszlo habrá que decir que el color que más le gusta es el negro, misterioso, mágico. Tanto así que puede venirle un impulso impostergable y un cuadro donde, digamos, primaría el azul o el rosado puede terminar resaltando el negro. Pocos son los cuadros de Szyszlo donde el blanco predomina. Junto con el claroscuro, le obsesiona la textura, pone pelitos, punti- 
tos, rayitas, se basa en Rembrandt y en sus veladuras para lograrla. Nuevamente vuelve a tener razón cuando dice que la textura enriquece un cuadro abstracto.

Entre los elementos que reconocemos en su pintura está el círculo, basado en unas líneas del poeta César Vallejo en las que se refiere a «los broches mayores del sonido». También la mesa-cama-altar-sacrificio ceremonial, que — para él— son «los tres actos sagrados, donde se come, donde se hace el amor y donde uno se vincula con las fuerzas extrañas, con lo inasible; lo que yo llamo 'lo sagrado laico'». Luego están el cuchillo y su agresividad, el tótem, el batir de alas, el sexo. Todo ello cobra una presencia primordial cuando Szyszlo toma el pincel.

Resultaría injusto descuidar el talento igualmente excepcional que tiene para la escultura. Sus esculturas pueden ser pequeñas o inmensas, pero siempre hermosas, cautivadoras. Son tótems imponentes, en bronce o en concreto, que revelan la facilidad de Szyszlo para las bellas artes. Aunque siempre le gustó esta forma de expresión su norte está en la pintura, es su mundo. Que en él no puedan coexistir estas dos inquietudes de manera fluida es una verdadera lástima, porque vaya que sus esculturas expresan belleza. Lo que referiré no es una infidencia, pues él así lo manifestó cuando conversamos años atrás sobre su obra: a Szyszlo la escultura le «friega». Perdón, seré más puntual, son más bien el barro, el yeso que todo ensucian. Y él es hiperpulcro en su trabajo, comprenderá el joven lector (también quien no lo es) el choque inevitable. No ha hecho más de veinte esculturas, incluidas las cajas en madera denominadas La ejecución de Túpac Amaru, que son igualmente espectaculares.

He llegado hasta este puerto y releyendo lo escrito temo haber incurrido en -llamémoslo así- el pecado de Matisse y me parece que he terminado comprendiendo a las ostras. Para redimirme sin tener que hacer penitencia tomaré un atajo, dejaré su magnífica obra y regresaré a su fascinante vida para entender mejor al artista. Quienes poseen la capacidad de crear tienen también el ingenio para desplegar su fantasía en otros ámbitos. Tal es el caso nuestro curioso pintor, quien entre las diversas aventuras que emprendió está la de crear carros de carnaval.

Esta es una etapa de la vida de Szyszlo que solo llama a la complicidad con él. Era un trabajo — digámoslo así — netamente alimentario, que le daba para vivir. Pero a la vez — por lo menos de lejos— se ve jocoso y divertido. Lima solía celebrar los carnavales con pompa, boato y, por supuesto, misses, la verdadera atracción para algunos. Resulta que las señoritas elegidas reinas paseaban en inmensos carros decorados por Szyszlo y otros artistas como Joaquín Roca Rey y Jorge Piqueras. Cuando decimos inmensos, nos referimos a plataformas de ocho metros de largo. La que albergaba a la Miss San Isidro, por ejemplo, representaba una caja de rosas gigantescas y dentro de cada una iba sentada una guapa limeña. Este oficio medio delirante le daba para vivir todo el año.

Es necesario tener en cuenta que Szyszlo ha sido visitado por todas las musas o las hechizó hábilmente. Si bien es un gran artista, creo que el término queda chico. En mi 
modestísima opinión, es una mezcla de filósofo con hombre renacentista de mirada múltiple. Su cultura es abrumadora, no porque tiene toneladas de información sino porque se ha internado en lo esencial de la naturaleza humana, siempre tratando de entenderla, de profundizar en ella. Encontrar a una persona cabal, ética siempre es cosa difícil, ahora si todo ello está acompañado de sabiduría es doblemente improbable.

¿Qué hace de Szyszlo un hombre sabio? Es un asunto difícil de responder porque son muchas las variables. Es versado en literatura como pocos e integra la Academia Peruana de la Lengua, ama la poesía y esta inspira su pintura, cuenta además con una memoria excepcional. Conoce las motivaciones de los diferentes movimientos artísticos que han moldeado la expresión plástica a lo largo del tiempo, aquí y fuera de aquí. Ha tenido y tiene amigos ilustres: Octavio Paz, Vargas Llosa, Cabrera Infante, Eielson, Moro, Arguedas, Sebastián Salazar Bondy, Sérvulo. Tuvo un loco pasaje por el cine y metió energía y tiempo en realizar un documental sobre Machu Picchu. Desafortunadamente el camarógrafo ¡no abrió el obturador de la cámara! Pequeño gran detalle del que solo se dieron cuenta cuando ya habían regresado a Lima.

A ello se suman sus interesantes reflexiones sobre el sentido de la pintura; sobre la vida, el amor y la muerte y el que conversar con él sea un deleite y un seguro aprendizaje. Agreguemos que posee un buenísimo sentido del humor, además de tener el don de contar chistes ingeniosos y graciosos. Como hemos convenido que este sea un ensayo no seguiré presentando todos los aciertos de Szyszlo, que conste nomás que si lo hago es porque lo consignado explica su seductora manera de pensar y de crear.

Si me detengo a precisar cuál sería el Waterloo de Szyszlo, la adversidad no remontada a pesar de sus cualidades, diría que son la política y la muerte. La derrota de Mario Vargas Llosa en 1990, el que no llegara a la presidencia fue sin duda una gran frustración para nuestro pintor. Trabajó mucho sin tener ambición por el poder, postergó su arte y empeñó toda su energía en una propuesta que consideraba honesta, pero que el país no entendió y rechazó. Primer y último intento de participar formalmente en un movimiento político.

Sin embargo, Szyszlo ha sido un infatigable impulsor de movimientos culturales de vanguardia, con mayor éxito que los políticos. Como cuando en 1947 fundó la Agrupación Espacio, que buscaba introducir los conceptos de la arquitectura contemporánea en el Perú. Querían vehementemente derrocar a la arquitectura neocolonial (tipo casa hacienda) predominante en la época y además promovían conciertos al aire libre de músicos contemporáneos. De hecho, la arquitectura moderna en el Perú le debe mucho a la Agrupación Espacio.

Como buen demócrata las dictaduras enervan a Szyszlo y como en el Perú no han faltado, su voz crítica durante la dictadura de Fujimori fue fundamental para combatirla. A su manera, no dejó de hacer política. Para alguien que no se fue a vivir fuera pudiendo hacerlo, pensar en el Perú es una necesidad (así suene un tanto huachafoso) de la cual no se va a desentender, por eso sus críticas son siempre atinadas y útiles. 
La muerte es un Waterloo más íntimo para Szyszlo, desde niño tuvo la vivencia de lo fugaz, de la finitud de la existencia. Adulto ya, pasó por la terrible experiencia de perder a un hijo y nada compensará esa pérdida. Al ser agnóstico, esta angustia queda desnuda, sin paliativos, pero Szyszlo la introduce en su pintura y logra un conjuro. Lo dicho sobre este, certeza ineludible por los escritores que admira, le sirve para comprender que todos los actos de este bicho llamado hombre «son una protesta contra la muerte, sabiendo que es inútil protestar porque es inevitable».

Una de las citas más hermosas sobre este vital tema, que cuando conversábamos trajo a colación Szyszlo «el memorioso», es la del poeta Gérard de Nerval. Se las brindo por si no la conocen: «Yo soy el tenebroso —el viudo—- el inconsolado, el príncipe de Aquitania de la torre abolida, mi única estrella ha muerto y mi laúd constelado porta el sol negro de la melancolía».

Los hombres buenos merecen ciertamente la inmortalidad, pero aunque Szyszlo esté en la lista no la quiere. «Sería horrible — nos dijo con su peculiar tono de voz y añadió-: nosotros poseemos una monstruosidad que se llama la memoria y la sensación del tiempo». Dicen que la inmortalidad se alcanza con la trascendencia, quedando en la historia, en la memoria de los pueblos. Nuestro pintor, mi valioso amigo, no cree en ello y lo expresa con crudeza: «Nadie se va a acordar. Pasados cincuenta años nadie se acuerda de nadie. Ni tus hijos, ni mis hijos, menos la gente. Para mí esos son los despojos de la batalla, lo que queda de ella. Lo importante es la batalla, estar vivo, tratar de hacer lo mejor posible. Lo demás no tiene importancia. Será como será».

La presencia de Szyszlo en la vida nacional es elocuente, se trata sin duda de un peruano fundamental. 


\section{Blanca Varela \\ (1926- )}

Giovanna Pollarolo 

En marzo de 2001 los periódicos anunciaron en un lugar más o menos destacado de sus páginas dedicadas a «cultura»: «Blanca Varela obtiene el Premio Octavio Paz de Poesía y Ensayo». Y en el desarrollo de la noticia muchos cronistas peruanos consideraron que había que explicar a los lectores que Blanca Varela era una "poetisa» nacida en Lima, que había sido esposa del pintor Fernando de Szyszlo y que tenía varios libros publicados; uno de ellos, el primero, con prólogo de Octavio Paz, quien fue su amigo y mentor.

Años después, en octubre de 2006, un titular ubicado en el lugar más destacado de la página de la sección cultural daba cuenta de un segundo galardón: «Blanca Varela gana el Premio Internacional de Poesía García Lorca». Esta vez se destacaba que la poeta peruana se había convertido en la primera mujer a la que se le otorgaba este premio y que su voz era considerada una de las más importantes no solo del Perú sino de Iberoamérica.

Apenas unos meses más tarde, en mayo de 2007, cuando Vicente de Szyszlo, el hijo de la poeta, se encontraba en la ciudad de Granada recibiendo el Premio Lorca en nombre de su madre, quien por motivos de salud no había podido viajar, el jurado, convocado conjuntamente por Patrimonio Nacional y la Universidad de Salamanca para conceder el Premio Reina Sofía de Poesía Iberoamericana en su XVI edición, anunció que por decisión unánime otorgaba el premio a la poeta peruana Blanca Varela «como reconocimiento al conjunto de su obra que por su valor literario constituye una aportación relevante al patrimonio cultural común iberoamericano y de España». Esta vez, la noticia rebasó el espacio de las secciones culturales, ocupando las primeras planas de los periódicos que destacaron los nombres de los poetas que habían recibido el Premio Reina Sofía en ediciones anteriores — Gonzalo Rojas (Chile), Álvaro Mutis (Colombia), Mario Benedetti (Uruguay), Nicanor Parra (Chile), Juan Gelman (Argentina) y los españoles Claudio Rodríguez, José Hierro, Ángel González, José Ángel Valente y Antonio Gamoneda-, para señalar que ahora los peruanos teníamos una poeta que estaba «a la altura y junto a» tan prestigiosos nombres. Blanca Varela era además, y otra vez, la primera mujer latinoamericana «que había recibido este galardón».

Estos importantes premios internacionales que se le han otorgado en los últimos años a la poeta Blanca Varela han puesto su nombre y su obra en un espacio público que hasta entonces ignoraba su existencia, ya sea porque este espacio es cada vez menos sensible al 
quehacer poético o porque, como señala Ana María Gazzolo: «La evolución de su poética ha ido en la dirección de una cada vez mayor concisión, ha buscado el encuentro con un lenguaje de apariencia seca, desnuda, que pudiera revelar una visión descarnada de la existencia, y ha llegado, en su poesía más reciente, a expresarse frecuentemente mediante toques o pinceladas aisladas que componen un cuadro de difícil lectura, cuyo desentrañamiento requiere del lector una inmersión en territorios usualmente no transitados ${ }^{12}$.

La parquedad y el hermetismo que dificultan la comprensión del poema por cuanto obligan al lector a desentrañar inasibles significados y sentidos pueden asociarse a la manera silenciosa y marginal como la poeta ha desarrollado su obra. Ya en 1979 José Miguel Oviedo señalaba: «La obra poética de Blanca Varela sigue siendo, pese a la definida cualidad y a la hondura de su visión, un corpus ignorado inclusive por buenos lectores y críticos de poesía» ${ }^{13}$. Obra poética ignorada a pesar no solo de los cuatro poemarios publicados hasta la fecha en que Oviedo escribe - Ese puerto existe, Luz de día, Valses y otras falsas confesiones y Canto villano—, sino porque el primero, Ese puerto existe, traía un prólogo de Octavio Paz en el que presentaba «el canto solitario de una muchacha peruana. El más secreto y tímido, el más natural $»^{14}$ y que insertaba a la joven poeta y su obra en la tradición literaria canónica. Oviedo señalaba: «El hecho es paradójico» ${ }^{15}$, en tanto que gracias al prólogo «su ingreso al mundo de la poesía no pudo ser más auspicioso». Es verdad: que un poeta reconocido y prestigioso como Paz presentara el primer libro de esta joven poeta «demasiado orgullosa (demasiado tímida) para hablar en nombre propio» ${ }^{16}$ inscribía a Blanca Varela en la tradición literaria canónica desde donde su obra se iría consolidando, adquiriendo prestigio y difundiéndose.

Pero el propio Oviedo constataba luego que la escasa o nula difusión de la obra de Blanca Varela "tras esta feliz inauguración ${ }^{17}$ —es decir, a pesar del «auspicioso prólogo» de Paz- era un hecho paradójico solo en la superficie, pues reconocía que si bien la obra de Blanca continuó desarrollándose, "lo hizo de un modo bastante más marginal, casi secreto y muy a pesar suyo». Y a continuación, Oviedo daba cuenta de lo que podríamos llamar la "carrera poética» de Blanca Varela desde Ese puerto existe hasta el presente en el que habla, Canto villano, 1979: «La decisión de publicar no es algo a lo que la autora llegue con facilidad y sin vencer los fantasmas del pudor. A lo largo de sus años de poeta, Blanca Varela no ha ganado un solo premio o reconocimiento literario de ninguna

\footnotetext{
12 Cfr. Gazzolo 2007: 74 .

13 Cfr. Oviedo 2007: 35.

14 Cfr. Paz 2007: 31.

15 Cfr. Oviedo 2007: 35.

16 Cfr. Paz 2007: 29.

17 Cfr. Oviedo 2007: 36.
} 
especie, por la sencilla razón de no haber participado en ningún concurso. Recelosa de las reuniones literarias, que suelen ser una desgracia de la vida intelectual, ni siquiera ha leído jamás públicamente sus poemas. Sus declaraciones y otros contactos con los lectores han sido parcos y las reseñas que su obra ha merecido pueden contarse con los dedos de la mano» ${ }^{18}$.

En mayo de 2007, en su «Elogio a Blanca Varela», publicado como epílogo de Nadie sabe mis cosas. Reflexiones en torno a la poesía de Blanca Varela ${ }^{19}$, Mario Vargas Llosa relata que conoció a Blanca Varela a mediados de 1958: «Desde ese primer día la quise y la admiré [...]. En medio siglo de amistad [...] la he oído hablar casi de todo. De esa generación de poetas del cincuenta de que formó parte [...]. De Breton y de los surrealistas, de Sartre, Simone de Beauvoir y los existencialistas. De sus filias y fobias literarias y de tanta gente que la impresionaba y que amó o detestó. Pero estoy seguro de no haberla oído jamás decir palabra sobre su propia poesía, y, en cambio, la he visto tantas veces, cuando la interrogaban sobre ella, escabullirse con frases esquivas y cambiar rápidamente de conversación ${ }^{20}$.

Casi treinta años después de que Oviedo en su pionero ensayo ya citado adjudicara la poca difusión de la obra de Blanca Varela al aislamiento, el secreto y la marginalidad como los lugares desde donde había cultivado su poesía, Vargas Llosa confirma la persistencia de tales lugares: «Entre todos los poetas de este tiempo que me ha tocado conocer, no hay uno solo tan ajeno a la feria de las vanidades y a la ilusión o a la codicia del éxito, como Blanca Varela $»^{21}$.

Y tal vez resulta válido referirse a una segunda paradoja en tanto que — no obstante la persistencia en el lugar del silencio y la soledad: «Que llegara a publicar esa media docena de libros ha sido una especie de milagro, más obra de la insistencia de sus amigos que de su propia voluntad $»^{22}$ - la poesía de Blanca Varela se empezó a difundir: en México aparece la primera edición de su poesía reunida, con el título de Canto villano y prólogo de Roberto Paoli, también se publican antologías en Venezuela y en España y sus libros se traducen al francés, inglés e italiano. Asimismo, en la década de 1990 publica tres nuevos libros, aumenta el número de reseñas, estudios críticos y tesis sobre su obra y

18 Cfr. Oviedo 2007: 36.

19 Excelente edición de Mariela Dreyfus y Rocío Silva Santisteban que reúne los primeros estudios críticos más importantes ya publicados sobre Blanca Varela (Oviedo, Paoli, Gazzolo, Castañón), así como ensayos posteriores que se encontraban dispersos en revistas y otros inéditos; asimismo la edición incluye una bellísima colección de fotos, entrevistas, testimonios, una amplia bibliografía y una antología seleccionada en 2005 por la propia autora. Los textos aquí reunidos facilitan enormemente cualquier trabajo de investigación; de hecho, la bibliografía de este ensayo es una prueba de ello.

20 Cfr. Vargas Llosa 2007: 468.

21 Cfr. Vargas Llosa 2007: 467.

22 Cfr. Vargas Llosa 2007: 467. 
llegan los tres importantes premios ya mencionados.

La paradoja a la que aludo es que si bien la obra poética de Blanca Varela dejó de ser desconocida o ignorada "por buenos lectores y críticos», esos que conforman aquella «inmensa minoría» que indaga en la poesía, y los premios recibidos llevaron su nombre a los titulares de los medios, la poeta no hizo nada para que esto ocurriera en tanto que no solo persistió en mantenerse alejada del «ruido público», siempre empeñada en no salir a la luz y ajena a la búsqueda del «éxito poético», sino que continuó desarrollando una poética cada vez más hermética, concisa, deliberadamente oscura, sin concesiones al facilismo o a la complacencia.

De allí que resulte paradójico que una obra escrita casi en la clandestinidad y ajena al afán de buscar lectores, fama, reconocimiento; en suma, «éxito», de pronto y sin buscarlos los alcance. En cierto modo, este «éxito» llegó solo, casi a pesar de la poeta, quien, debido a la mayor difusión de su obra, no tuvo más remedio que acceder esporádicamente a participar en algunos recitales y a conceder entrevistas en las cuales se refiere a sus «éxitos poéticos» con cierto desdén. Cuando Rosina Valcárcel la entrevistó en 1997, afirmó: «Siempre es excesivo lo que opina la crítica sobre mi obra. No creo que mi obra merezca tanta atención» y le hace saber a la entrevistadora, a manera de confesión marcada sutilmente por la ironía: «A mí no me gusta mi poesía, pero es la única que puedo escribir. Es una poesía honesta; no podría haber escrito de otra manera». Intuyo que Rosina Valcárcel le habrá preguntado con asombro: «¿Por qué no le gusta su poesía, su poesía tan laboriosa, honesta, coherente, rigurosamente trabajada a lo largo de toda su vida?», pues Blanca se repregunta: «¿Por qué no me gusta mi poesía?». Y responde: «Tal vez porque soy una insatisfecha, creo que es el destino de toda persona que aspira a ser auténtica; eso sí, creo que ser auténtico es buscar siempre algo que uno no alcanza»»3 ${ }^{23}$ uno tiene la impresión de que se está contestando más a sí misma, para sí misma. Y uno recuerda los versos de "Curriculum vitae», ese poema en el que palabras como "carrera» y «premio» aluden al «éxito» que deviene en un imposible, en una lucha condenada al fracaso: «digamos que ganaste la carrera y que el premio / era otra carrera / que no bebiste el vino de la victoria / sino tu propia sal / que jamás escuchaste vítores / sino ladridos de perros / y que tu sombra / tu propia sombra / fue tu única / y desleal competidora» ${ }^{24}$.

No queda ninguna duda de que la obra de Blanca Varela está marcada de principio a

23 Cfr. Valcárcel 2007: 452.

24 Todos los poemas que cito de la autora están incluidos en Varela 2001. Estos versos se encuentran en la página 150 . 
fin, desde el primer poemario, Ese puerto existe, hasta Falso teclado ${ }^{25}$, por la voluntaria y coherente decisión de desarrollar su trabajo poético alejado de los ruidos públicos. Y tal decisión obedece a un compromiso personal, profundo, absolutamente auténtico con la poesía; compromiso que, con cierta ironía y evitando solemnidades, la poeta llama «enfermedad irremediable», «vicio» en el sentido de adicción, de inclinación por algo que no se puede dejar: «Alguien ha dicho algo que para mí es cierto: que la poesía es un vicio que se adquiere con la infancia. También es cierto que algunos se curan con los años, y otros quedamos enredados para siempre en sus buenas o malas artes ${ }^{26}$. Compromiso que Mario Vargas Llosa ha calificado con el nombre de "pasión»: «La poesía ha sido la pasión más sostenida de su vida ${ }^{27}$.

Blanca Varela quedó «enredada» para siempre por la poesía; la conoció cuando niña, se hizo adicta a ella y no la abandonó jamás. Este «vicio», llámese «compromiso», «pasión», «destino» ejercido en un espacio que la poeta quisiera privado y compartido en silencio y soledad con sus lectores, «un vicio recóndito, inconfesable, cultivado en la clandestinidad, con celo y reserva tenaces, como si su exposición a la luz, a los ojos de los demás, pudiera dañarlo ${ }^{28}$ marca su itinerario de vida y su itinerario poético que en un sentido conforman uno solo, aun cuando Blanca Varela haya desarrollado su poesía lejos del quehacer cotidiano y profesional. Trabajando en diversos oficios — periodista, editora, gerente del Fondo de Cultura Económica, entre otras ocupaciones-, mantuvo su trabajo poético, riguroso y sin concesiones en la más absoluta clandestinidad y, como se ha dicho, casi en silencio: ocho poemarios y un total de ciento cuarenta poemas en casi cincuenta años: «Puedo escribir muchas páginas y de pronto me quedo con muy pocas líneas, porque el poema está allí metido, hay que saber encontrarlo», le confiesa a Rosina Valcárcel ${ }^{29}$, explicando indirectamente su empeño en la parquedad, su rechazo al exceso. Y uno admira la coherencia de su compromiso, cómo se puede ser profunda e irremediablemente fiel a la poesía sin dar señales exteriores de ello, sin hacerlo público, negándose incluso a la escritura: «Yo me pongo muchas dificultades para escribir poesía; muchos obstáculos, tremendas trampas. Primero no me siento al lado que me debo de sentar para escribir poesía, no tengo un lápiz a la mano cuando quiero escribir; es decir, hago todo lo imposible para no escribir poesía. Suena ridículo, pero es verdad; ya cuan-

25 Luego de los primeros cuatro poemarios ya citados hasta 1979, Blanca Varela publicó Ejercicios materiales y El libro de barro, ambos en 1993 y después de quince años de silencio; Concierto animal, en 1999, y en la edición de su poesía reunida incluyó su último poemario, El falso teclado (2000).

26 Cfr. Varela 2007: 22.

27 Cfr. Vargas Llosa 2007: 467.

28 Cfr. Vargas Llosa 2007: 467.

29 Cfr. Valcárcel 2007: 453. 
do me encuentro con esta especie de batalla, entonces allí los obstáculos ya son de otra índole. Entonces hay cosas que yo no quiero, que son fáciles y que yo evito; la facilidad me molesta $»^{30}$.

La vida y obra de Blanca Varela se nos muestra como una clara expresión de un itinerario que da cuenta del camino recorrido trazado desde la pasión y el compromiso con los que asumió la poesía. Un itinerario en el que la vida explica la obra; y la obra, la vida. Mi empeño, en lo que sigue, es referir ese itinerario en su fase formativa, inicial; esa fase donde se fijan los hitos de un quehacer en los que vida y obra se confunden, se alimentan, enriquecen, se hacen una indescifrable unidad que trasciende el testimonio, la confesión o la autobiografía.

«Mi madre no fue a la universidad, mi abuela tampoco».

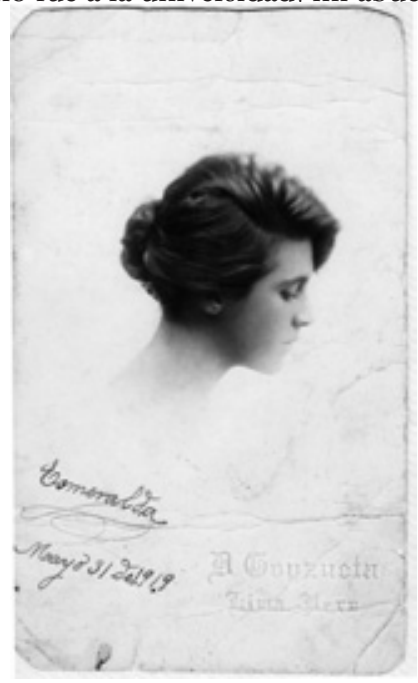

Esmeralda González, madre de Blanca Varela, en foto estudio de 1918.

En la foto vemos a Esmeralda González (1902-2003), la madre de Blanca Varela, más conocida como Serafina Quinteras. Fue periodista, poeta, escribió letras de valses criollos, guiones para radionovelas, relatos costumbristas. Esmeralda es a su vez hija de otra escritora, Delia Castro de González (1874-1939), y nieta de Manuela Antonia Márquez (1844-1890). Delia escribió poemas humorísticos, artículos periodísticos y guiones que lamentablemente no han sido recopilados; y el poemario Sin rumbo. Manuela, la fundadora de esta genealogía de escritoras, era hermana de José Arnaldo y Luis Enrique Márquez, quienes apoyaron su formación humanística. Colaboró con sus hermanos en la edición de la revista Cosmorama (1867) y se casó con el cantante, actor, poeta, periodista y empresario español Juan Castro

30 Cfr. Valcárcel 2007: 457. 
y Osete. Como bien señalan Castañeda y Toguchi, en un original trabajo que indaga en la tradición poética de Blanca Varela, estamos ante «un sujeto que se construye remitiéndose a sí mismo como su propia causa y no como un producto del entorno familiar», y cuya poesía cuestiona "su tradición familiar inmediata»" ${ }^{31}$ Sin embargo, esta genealogía en la que se inserta fue determinante en su trabajo poético. Varias declaraciones de Blanca Varela iluminan en cierto modo su relación con su tradición familiar.

En la entrevista de Rosina Valcárcel, ya citada, Blanca Varela se refiere en varias ocasiones a su tradición literaria familiar. «Cuando a los 7 años garabateé mis primeros versos mi abuela y mi madre reaccionaron como suelen reaccionar los seres que nos quieren; piensan que todos en la familia — entre comillas_ son muy inteligentes», recuerda. Y a continuación expresa su sospecha de que "quizá el hecho de haber sido criada en un hogar de mujeres influyó en mi capacidad de observar el mundo, el entorno». Cuenta que, según su abuela, era una niña "fantasiosa». Quien ha leído su testimonio en el que da cuenta de su relación con la poesía puede imaginar a la pequeña niña «fantasiosa» ${ }^{32}$ abstraída en su juego con las palabras, el inicio del «vicio» por la poesía adquirido en la infancia cuando habla del principio: «Todo comenzó desde muy niña, como un juego secreto y obsesivo. Recuerdo claramente que no me gustaba mucho lo que me rodeaba y que, al mismo tiempo, me gustaban mucho las palabras, su sinsentido, su música ${ }^{33}$.

Con absoluta lucidez Blanca Varela se distancia de la poesía de su madre y de su abuela, que no fueron a la universidad: «Eran buenas lectoras, eran personas que habían tenido más bien un tipo de universidad familiar. [...] Yo, digamos, fui más moderna, tuve acceso a ciertas cosas, entonces todo lo 'popular' aprendido en casa era un lastre para poder avanzar» ${ }^{34}$. Su relación con el mundo de los valses, la guitarra, la música criolla, las letras escritas por Serafina es, qué duda cabe, una relación complicada, ambigua y difícil de desentrañar que Valses y otras falsas confesiones y Canto villano, su tercer y cuarto poemario, respectivamente, expresan de alguna manera. Cito la interpretación de Paoli al referirse al poema «Valses» como «un buen ejemplo de la pasión vareliana ligada al recuerdo, más abierta y descifrable, no avara en palabras ni en cadencias, y, sin embargo, refrenada en su canto por fragmentos prosísticos intercalados, por citas de viejos valses peruanos, que tienen la función de interrumpir y templar lo emotivo. Este poema está dedicado, con doble posibilidad de lectura, a Lima o a la madre: la madre, en efecto, limeñísima, fue en el pasado una conocida compositora de valses y autora de textos criollos, así que las dos imágenes, la materna y la de la ciudad natal, pueden muy

31 Cfr. Castañeda y Toguchi 2007: 105.

32 Cfr. Valcárcel 2007: 444.

33 Cfr. Varela 2007: 22.

34 Cfr. Valcárcel 2007: 446. 
bien superponerse en la mente de la autora ${ }^{35}$.

En una larga conversación sostenida en Caracas en 1996 con la poeta Yolanda Pantín construida a manera de «retrato de memoria», Blanca Varela parece haber llegado a la conciliación, desde la madre como metáfora, entre esos dos mundos que parecían inconciliables en «Valses» y otros poemas: lo «popular» y lo «culto», lo «alto» o «canónico y lo «bajo» que la poeta cuando joven juzgó que era un lastre para avanzar y la llevó a escribir: «No sé si te amo o te aborrezco / como si hubieras muerto antes de tiempo / o estuvieras naciendo poco a poco / penosamente de la nada siempre» ( Valses $\left.{ }^{36}\right)$ o los duros versos que interpelan y acusan: «Ve lo que has hecho de mí, la santa más pobre del museo, la de la última sala, junto a las letrinas, la de la herida negra como un ojo bajo el seno izquierdo» («Vals del ángelus» $\left.{ }^{37}\right)$.

«Me llevo estupendamente bien con mi madre. Es una mujer fantástica. Tiene 91 años y todavía usa tacones. Además, huele a rosas. Se ha casado tres veces, una mujer muy fuerte, llena de vitalidad. Es una especie de gloria patria, la gente la adora, sus cumpleaños son fiestas nacionales, escribe poemas populares, canciones. Mi madre me admira mucho, está muy pendiente de mí» ${ }^{38}$.

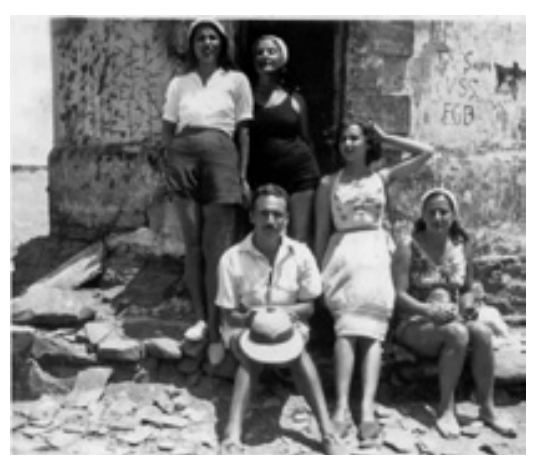

Nita Zapata, Alicia Bustamante; abajo, Arguedas, Blanca Varela y Cecilia Bustamante, en Supe. «El mundo - mi mundo - se hizo mayor, más grande y respirable»

Esta foto es un magnífico testimonio de los años juveniles cuando Blanca Varela conoció en San Marcos a Sebastián Salazar Bondy, quien la introdujo no solo al grupo de jóvenes poetas que serían sus compañeros en el aprendizaje de la escritura, la lectura, la pintura, la música y el teatro, sino al mundo de los escritores mayores: «Gracias a él conocí a escritores de carne y hueso; poetas y novelistas que caminaban por las calles de Lima. Los mayores, los

\footnotetext{
35 Cfr. Paoli 2007: 52.

36 Cfr. Varela 2001: 93.

37 Cfr. Varela 2001: 99.

38 Cfr. Pantín: 463.
} 
mejores, [...]. Entre ellos, dos en particular: un novelista y un poeta [...]. Me estoy refiriendo a José María Arguedas y a Emilio Adolfo Westphalen ${ }^{39}$. En muchas ocasiones la poeta ha declarado su admiración y respeto a ambos escritores y el impacto que tuvieron en su obra: «La poesía que escribo no sería la que es sin esas dos influencias que jamás se me impusieron de manera inmediata ni anecdótica, sino, más bien, en esa forma sutil, misteriosa, velada y alusiva $»^{40}$. En estos primeros años universitarios conoce también al joven pintor Fernando de Szyszlo, quien sería su esposo y frecuentan la tertulia de la peña Pancho Fierro. Allí se encuentran con Arguedas, las hermanas Bustamante, César Moro, Julia Codesido y muchos otros intelectuales y artistas. Blanca Varela y Fernando de Szyszlo pasan algunos días de verano en la casa de playa de José María Arguedas y Celia en Supe. Fueron tiempos felices antes de partir a París, tiempos en los que la poeta aprendió de Arguedas, de "su manera de vivir, su manera de hablar, de ver el mundo, y especialmente (de) su obra, una verdad oscura, dolorosa e impronunciable, con la que hemos nacido todos los peruanos, aunque pretendamos ignorarla ${ }^{41}$; tiempos en los que empezó a fraguar su primer poema, que tituló «en secreto homenaje a Arguedas: 'Puerto Supe'»"

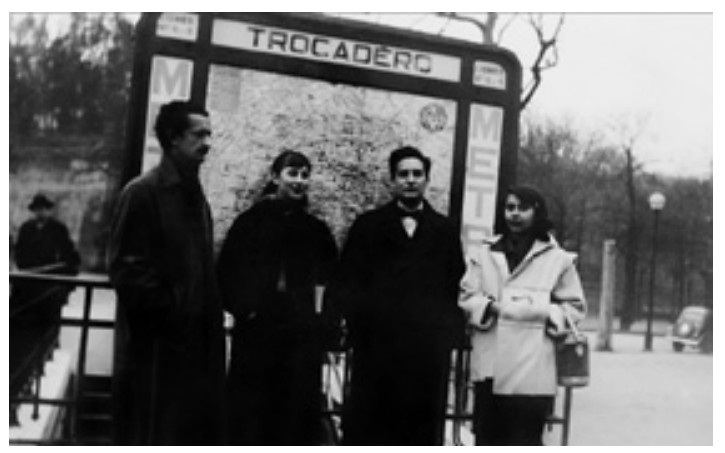

Fernando de Szyszlo, Michele Delandrier, Octavio Paz y Blanca Varela en París, 1950. «En esa selva infernal y celeste a la vez».

París. En 1949 la joven poeta y el joven pintor se casan y casi de inmediato emprenden el viaje mítico a París. Eran entonces, lo ha dicho ella misma, «jóvenes provincianos, atemorizados por las luces de la gran ciudad» ${ }^{43}$. Llegaron «muy desconcertados, con más ilusiones que dinero ${ }^{44}$; buscaban «a través del arte, de la poesía, una nueva manera de ser y de estar en ese

$\begin{array}{ll}39 & \text { Cfr. Varela 2007: } 23 . \\ 40 & \text { Cfr. Varela 2007: } 24 . \\ 41 & \text { Cfr. Varela 2007: } 24 . \\ 42 & \text { Cfr. Varela 2007: } 24 . \\ 43 & \text { Cfr. Varios 1999: } 15 . \\ 44 & \text { Cfr. Varios 1999: } 13 .\end{array}$ 
mundo 'moderno' [en el] que teníamos que aprender a vivir ${ }^{45}$. Era el París de la posguerra. Allí la joven pareja conoció a Octavio Paz: «Sin exageración, Paz fue nuestro Virgilio en esa selva infernal y celeste a la vez que era el París de entonces». Los vinculó con "gente de toda edad y de diversos orígenes»: los escritores José Bergamín, Julio Cortázar, Arturo Serrano Plaja, José Palau, el filósofo Kostas Papaionus, el poeta Carlos Martínez Rivas. «Octavio también nos llevó hasta las márgenes de otro río, que no era el Sena, que parecía adormecido, pero donde rugía, mágico, como siempre el surrealismo» ${ }^{46}$. Primero con de Szyszlo, y luego sola, Blanca permanece en París casi una década: conoció a André Breton, a Jean-Paul Sartre, a Simone de Beauvior, a Michaux, a Giacometti, a Léger. Pero es el encuentro con Paz el que la poeta rememora y celebra con especial gratitud: «He conocido a mucha gente que me ha estimulado para escribir y creo que Octavio fue el más exigente y el que me otorgó mayor confianza» —y concluye—: «Creo que haber conocido a Octavio Paz en mi primera juventud, llena de dudas, inseguridad y temores, fue lo que me hizo escoger la poesía como mi inevitable oficio» ${ }^{47}$.

«Una recién nacida identidad».

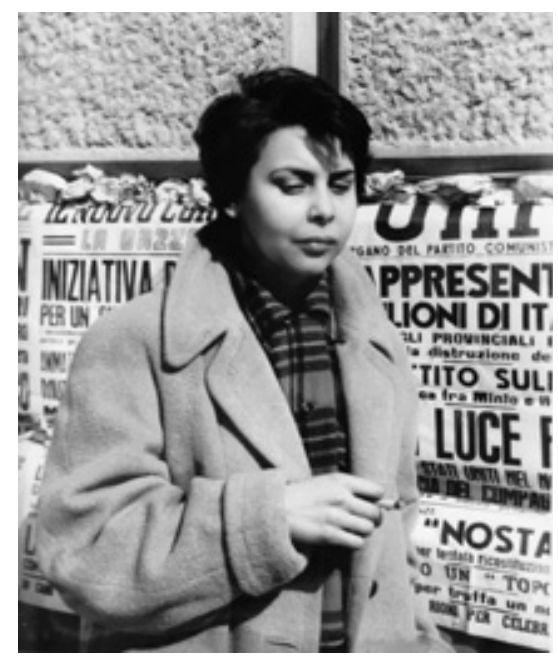

Blanca Varela en Florencia, frente a un afiche de Unitá, órgano del Partido Comunista Italiano, 1955.

París «fue una época feliz y desgraciada a la vez. Fue duro ese aprendizaje de vida, en que tratamos de convertirnos en personas, en seres reales ${ }^{48}$. Y la aventura terminó, «París tenía que acabarse ${ }^{49}$ porque un ciclo se estaba cerrando a la par que iba naciendo una

$\begin{array}{ll}45 & \text { Cfr. Varios 1999: } 17 . \\ 46 & \text { Cfr. Varios 1999: } 16 . \\ 47 & \text { Cfr. Varios 1999: } 17 . \\ 48 & \text { Cfr. Varios 1999: } 17 . \\ 49 & \text { Cfr. Varela 2007: } 25 .\end{array}$ 
identidad que era necesario preservar y "que tenía que ver profundamente con lo que estaba tratando de expresar con mis poemas ${ }^{50}$; así es como la poeta alude a los poemas que diez años más tarde publicará bajo el título de Ese puerto existe con el famoso prólogo de Paz. Los escribe en una pequeña habitación del Barrio Latino, «tratando de recordar los cantos peruanos, lejanísimos y misteriosos de Arguedas, y de nombrar y recrear mis paisajes de infancia, y llevar mis animales y mis astros, enormemente altos y distantes, hasta mi pequeña ventana de la rue de Lanneau ${ }^{51}$. «Está mi infancia en esta costa / bajo el cielo tan alto / cielo como ninguno, cielo, sombra, veloz / nubes de espanto, oscuro torbellino de alas / azules casas en el horizonte» ("Puerto Supe ${ }^{52}$ ), escribe en París disponiéndose para el regreso en pos de preservar esa «recién nacida identidad». Y fue Florencia la ciudad del tránsito, la ciudad desde donde la pareja nuevamente unida emprendió el viaje de retorno; viaje que marca el final de los años formativos de la poeta.

¿Y después, Blanca? ¿Qué pasó después?

«Lo que pasó después, lo demás, si no está escondido entre mis poemas, está entonces definitivamente perdido. Hablo de lo que hace la vida de cualquier persona, de cualquier mujer, como es mi caso. La casa, el amor, los niños, la lectura, la música, los viajes, la ciudad, y también el tedio, el dolor, la impotencia, la soledad y el silencio»" ${ }^{53}$.

En este párrafo final de su testimonio, uno de los pocos que la poeta ha escrito, menciona sus poemas pero no el éxito, y sabemos por qué: no lo buscó, la perturban el ruido, los aplausos. «No soy una persona a la cual le importa el éxito, definitivamente no me importa y no creo en él. Creo que inclusive es hasta nocivo» ${ }^{54}$. Pero ¿̇de qué otra manera, si no es con el aplauso y la celebración por los premios y el reconocimiento podemos expresar los lectores nuestra admiración y agradecimiento a una obra cuyo misterio nos deslumbra y cuya austeridad se nos revela como ejemplar? Ana María Gazzolo ha escrito con meridiana precisión que la obra de Blanca Varela «se impone a quien la lee, lúcida, fuerte, sin ambages; penetra el hueso de la vida, atraviesa la carne desgarrada, desecha la piel, la suavidad, la apariencia; padece las arduas luchas de la especie, no propone un mundo ilusorio ni una puerta abierta que no sea la de la muerte ${ }^{55}$. Pienso que Blanca Varela les habla a esos lectores y lectoras que no huyen de su poesía implacable, dura, áspera, que cuestiona y acusa; a esos lectores que se atreven a transitar por el dolor, la náusea, el estupor y el desencanto; a esos lectores que no la aplauden por los premios ni los titulares ni por la novedad de agregar a una peruana reconocida internacionalmente

\footnotetext{
50 Cfr. Varela 2007: 25.

51 Cfr. Varela 2007: 26.

52 Cfr. Varela 2001: 25.

53 Cfr. Varela 2007: 26.

54 Cfr. Valcárcel 2007: 456.

55 Cfr. Gazzolo 2007: 83.
} 
en la magra lista de celebridades porque saben, como ella, que la poesía no es una carrera, que no hay victoria ni vítores; que es el «Falso teclado», el lugar del silencio que suena, de lo invisible que pretendemos ver:

toca toca

todavía tus dedos se mueven bien

el dedo de la nieve y de la miel

hacen lo suyo

nada suena mejor que el silencio

nuestro desvelo es nuestro bosque

aguza el oído como una hoz

a trillar lo invisible se ha dicho

para eso estamos

para morir

sobre la mesa silenciosa

que suena.

\section{BibLiOgRAFÍA}

CASTAÑEDA, Esther y TOGUCHI Elizabeth (2007). «Blanca Varela y su tradición poética», pp. 99-108. En: Nadie sabe mis cosas. Reflexiones en torno a la poesía de Blanca Varela. Dreyfus, Mariela y Silva-Santisteban, Rocío (selección, prólogo y notas). Lima: Fondo Editorial del Congreso de la República del Perú.

GAZZOLO, Ana María (2007). «Blanca Varela: más allá del dolor y del placer», pp. 73-83. En: Nadie sabe mis cosas. Reflexiones en torno a la poesía de Blanca Varela. Dreyfus, Mariela y Silva-Santisteban, Rocío (selección, prólogo y notas). Lima: Fondo Editorial del Congreso de la República del Perú.

OVIEDO, José Miguel (2007). «Blanca Varela o la persistencia de la memoria», pp. 35-45. En: Nadie sabe mis cosas. Reflexiones en torno a la poesía de Blanca Varela. Dreyfus, Mariela y Silva-Santisteban, Rocío (selección, prólogo y notas). Lima: Fondo Editorial del Congreso de la República del Perú.

PANTÍN, Yolanda (2007). «Encuentro con Blanca Varela», pp. 461-466. En: Nadie sabe mis cosas. Reflexiones en torno a la poesía de Blanca Varela. Dreyfus, Mariela y Silva-Santisteban, Rocío (selección, prólogo y notas). Lima: Fondo Editorial del Congreso de la República del Perú.

PAOLI, Roberto (2007). "Una visión lúcida y desencantada», pp. 47-53. En: Nadie sabe mis cosas. Reflexiones en torno a la poesía de Blanca Varela. Dreyfus, Mariela y Silva-Santisteban, Rocío (selección, prólogo y notas). Lima: Fondo Editorial del Congreso de la República del Perú.

PAZ, Octavio (2007). «Destiempos de Blanca Varela». Prólogo a Blanca Varela, Ese puerto existe, 
pp. 29-33. En: Nadie sabe mis cosas. Reflexiones en torno a la poesía de Blanca Varela. Dreyfus, Mariela y Silva-Santisteban, Rocío (selección, prólogo y notas). Lima: Fondo Editorial del Congreso de la República del Perú.

VALCÁRCEL, Rosina (2007). «Blanca Varela. Esto es lo que me ha tocado vivir», pp. 443-459. En: Nadie sabe mis cosas. Reflexiones en torno a la poesía de Blanca Varela. Dreyfus, Mariela y Silva-Santisteban, Rocío (selección, prólogo y notas). Lima: Fondo Editorial del Congreso de la República del Perú.

VARELA, Blanca (1959). Ese puerto existe. Xalapa: Universidad Veracruzana.

(1963).Luz de día. Lima: Ediciones de la Rama Florida.

(1972). Valses y otras falsas confesiones: Lima: Instituto Nacional de Cultura.

(1978). Canto villano. Lima: Ediciones Arybalo.

(2001). Donde todo termina abre las alas. Poesía reunida (1949-2000). Barcelona: Galaxia Gutenberg / Círculo de Lectores.

(2007). "Antes de escribir estas líneas», pp. 21-26. En: Nadie sabe mis cosas. Reflexiones en torno a la poesía de Blanca Varela. Dreyfus, Mariela y Silva-Santisteban, Rocío (selección, prólogo y notas). Lima: Fondo Editorial del Congreso de la República del Perú.

VARIOS (1999). Homenaje a Octavio Paz 1914-1998. «Testimonio de Blanca Varela». Lima: Estudios Generales Letras. Pontificia Universidad Católica del Perú.

VARGAS LLOSA, Mario (2007). «Elogio de Blanca Varela», pp. 467-470. En: Nadie sabe mis cosas. Reflexiones en torno a la poesía de Blanca Varela. Dreyfus, Mariela y Silva-Santisteban, Rocío (selección, prólogo y notas). Lima: Fondo Editorial del Congreso de la República del Perú.

«El hombre (cada hombre) es un fin en sí mismo, no el medio para los fines de otros. Debe existir por su propio esfuerzo, sin sacrificarse a otros ni sacrificar a otros para sí. La búsqueda de su propio interés racional y de su propia felicidad es el más alto propósito moral de su vida». 



\section{LUIS BANCHERO ROSSI}

(1929-1972)

\section{Daniel Córdova CaYo*}

* Con la colaboración de Gonzalo Carranza.

Este texto es un regalo para mis hijas Elsa y Laura Córdova Banchero. Algo de esa sangre genovesa corre por sus venas. 

Ayn Rand

\section{Auge y TRAgEdia de UN “CAPITÁN DE INDUSTRIA"}

Luis Banchero Rossi fue uno de esos personajes que escasearon en el siglo XX en el Perú. Un "Capitán de Industria”, un empresario en el sentido «schumpeteriano» del término ${ }^{56}$. Observador. Atento a las oportunidades de negocio que, como siempre, surgen de la posibilidad de satisfacer una necesidad. Emprendedor. Ágil al momento de organizar la producción del bien o del servicio para cubrir necesidades insatisfechas. Vendedor nato. Haciendo lo indecible para colocar la producción disponible y culminar con éxito el proceso empresarial.

La historia de Banchero es la historia de un empresario moderno. Un empresario que no solo innovó como lo hace cualquier empresario que logra abrirse paso en los negocios, sino que participó en el surgimiento de una nueva industria, la producción y exportación de harina de pescado. Industria que, por añadidura, se convertiría hasta el día de hoy en uno de los ejes de la vinculación del Perú con la economía mundial.

Pero la historia empresarial de Banchero fue más que eso. Su corta vida le alcanzó para fundar el que es hasta hoy uno de los grupos editoriales más importantes del país: Empresa Periodística Nacional (Epensa), empresa que edita, entre otros, los diarios Correo y Ojo. Y al estilo de los magnates rusos o árabes de hoy, adquirió un pequeño equipo de fútbol, el Defensor Lima, en el cual llegó a jugar media selección peruana de fútbol, y que en 1973, aún financiado por los herederos de Banchero, ganó el campeonato local y clasificó a la Copa Libertadores de América.

Como suele ser la historia de los emprendedores que sostienen la aparición de nuevas industrias, Banchero hizo fortuna muy joven. No tenía treinta años cuando se consolidaba como uno de los líderes empresariales de mayor fortuna en el mundo. Su historia es, en ese sentido, comparable con la de los contemporáneos jóvenes millonarios de internet.

56 Joseph Schumpeter fue el economista del siglo XX que mejor definió el papel del empresario en la economía de mercado. Cfr. Schumpeter 1912. 
Pero su vida, sobre todo el final de su vida, nos remite a una tragedia propia de una celebridad política o artística. Murió asesinado, como John F. Kennedy (JFK), al iniciar su cuarta década de vida. Y, como en el caso de JFK, nunca se supo a ciencia cierta quién lo mandó matar. Murió joven, como James Dean. Y, como en el caso del joven seductor, nunca sabremos cómo hubiese sido su rostro de viejo, expuesto cuatro décadas más a los embates del tiempo.

\section{Cuando Lulo SE CONVIRTió EN EMPREsario}

Luis Damián Banchero Rossi nació en una tradicional casa-quinta de la ciudad de Tacna el 11 de octubre de 1929, tan solo semanas después de que se decidiera su reintegración al territorio peruano luego de décadas en manos chilenas. Era el primer hijo de Luigi Banchero, un inmigrante italiano que había peleado en la Primera Guerra Mundial contra los alemanes, y de Florencia Rossi. Formó parte de ese pequeño pero significativo grupo de tacneños descendientes de italianos que luego harían historia en el Perú, junto con los Cúneo, Lombardi, Canessa, Castagnola, Ghersi, Machiavello, Raffo y Solari, entre otros ${ }^{57}$.

La sangre genovesa de Banchero estaba impregnada de aquello que otro economista que marcaría el siglo XX, John M. Keynes, llamó «el espíritu animal de los empresarios» ${ }^{58}$. El negocio de su padre era una pequeña bodega de vinos y aguardientes, El Carrión. Estudió en el colegio estatal al que la mayoría de familias tacneñas enviaba a sus hijos. Los recuerdos de Banchero en esa época son los de un niño precoz, cuyo sentido de la organización llamaba la atención. Según un artículo del suplemento dominical del diario La Prensa, Banchero «era un gordito alegre y juguetón, contaba su tío Waldemar Rossi, que vivía a pocas cuadras de la casa de los Banchero. El pequeño 'italianito', al que cariñosamente lo llamaban 'Lulo' por lo gordito que era, acreditó desde pequeño un espíritu empresarial. Refieren sus familiares que le gustaba mucho ayudar a su padre en la venta de vinos. Cuando era joven, hacía planes para agrandar la bodega, seguro de que algún día asumiría las riendas del negocio" "59. Durante su paso por la secundaria fundó la brigada de Boy Scouts Tacna 1. Fue capitán de las barras de su escuela y ocupó los primeros puestos

57 Cfr. Salazar 2008.

58 «Si nuestros instintos se tornan débiles —escribió Keynes- y el optimismo espontáneo vacila, dejándonos a solas con nuestros cálculos matemáticos de expectativas, el espíritu animal desvanece y muere, aunque los temores a incurrir en pérdidas pueden no tener una base más racional que las esperanzas de obtener beneficios... Se puede afirmar, sin miedo, que el espíritu animal que depende de las esperanzas puestas en el futuro beneficia a la comunidad, pero la iniciativa individual solo será adecuada cuando al cálculo y la racionalidad se le añada el apoyo de los instintos, de forma que la idea de contabilizar pérdidas que puede detener a los pioneros se deja a un lado, al igual que el hombre lleno de salud hace caso omiso de la idea de que alguna vez tendrá que morir». Cfr. Keynes, 1936, capítulo «El Estado de las expectativas de largo plazo». (Traducción http://alejandrogregori.com.ar/2008/10/07/el-animal-spirit-de-keynes/). 
de su clase.

En 1944, terminado el colegio, decidió estudiar ingeniería química en Trujillo. Ahí lo recibiría su tío Benito Rossi, hermano mayor de su madre, a quien Lulo conocía solo por fotografías. Cuenta Guillermo Thorndike ${ }^{60}$ que, ni bien llegado a Trujillo, Lulo pidió que lo llamen Lucho. Venía dispuesto a convertirse en adulto.

Su historia universitaria fue tan solo una anécdota en lo que sería su vida profesional. Graduado de ingeniero químico con las mejores notas, su incursión en los negocios se inició desde su primer año de estudios. Cuentan que apenas aprendió el proceso para hacer jabón, no dudó en fabricarlo en pequeñas cantidades y venderlo con éxito a bajo precio a la colonia china de Trujillo. Pensaba todo el tiempo en negocios. Descartó la tentación de participar en el fácil e ilícito negocio del contrabando, que tan frecuente sería entre Tacna y Arica a lo largo del siglo XX. «Lentamente emergió un hombre obsesionado por la acción, que no hacía suyas las cosas para deleitarse en la posesión sino para marcarlas como propias y abandonarlas sin una mirada ${ }^{61}$. Vendió en Trujillo vinos de la bodega paterna, medias, discos, automóviles. Y enviaba piñas desde el norte para su exportación a Chile. Era la personificación de la acción humana, del motor emprendedor que como bien insistía Ludwig von Mises, es el rasgo esencial de la economía y el progreso ${ }^{62}$.

Empezó entonces el negocio de venta al por mayor de productos enlatados, toda una novedad en la época. "Ganaba, quizá, unos mil soles al mes», contó en una entrevista. Rápidamente, encontró un nuevo giro, más lucrativo. Un artículo de la revista La Olla, publicado en setiembre de 1968, lo narró así. "Retrocedamos a 1951. Estamos en Trujillo, Perú. Un muchachón de veintiún años de edad, estudiante de Química en la Universidad de La Libertad, visitaba con frecuencia la hacienda Laredo. Daba vueltas en su imaginación a las fórmulas increíbles del carbón en el mundo de los hidrocarburos; pero allí a la mano tenía la glucosa. El azúcar era un negocio complicado. Pero existía la melaza, subproducto que se arrojaba a los caminos para evitar el polvo: de utilización incompleta. Casi un estorbo» ${ }^{63}$. Lulo se preguntaba si podía hacerse algo con tanto subproducto desperdiciado. Su amigo Isidoro Loebl, el administrador de la hacienda, trajo la respuesta de Estados Unidos: servía para alimentar ganado mezclada con forraje. Y en sus propias palabras: «El estudiante, con un frasco de melaza, viajó a Lima. Visitó un sitio y otro. Semanas después, camiones llenos de cilindros de melaza comenzaron a invadir los establos de ganado lechero de la Gran Lima. Se abría un nuevo mercado» ${ }^{64}$.

\footnotetext{
60 Cfr. Thorndike 1973.

61 Cfr. Thorndike 1973: 69.

62 Cfr. Von Mises 2001.

63 Cfr. Arévalo 1995: 89.

64 Cfr. Arévalo 1995: 89.
} 
Pronto Banchero se hizo conocido en Trujillo como un joven con gran capacidad para los negocios. Fue así que Carlos A. Manucci, conocido empresario de la región, le propuso la gerencia de una nueva compañía que se dedicaría a la comercialización de lubricantes: Importadora Trujillo S. A. Banchero no solo quería la gerencia. Nunca se conformó con ser empleado. Solicitó y obtuvo también participación accionaria. Con sus ahorros, aportó en efectivo el capital que le correspondía. Manucci, distribuidor de Ford Motor Co., había obtenido en 1951 la exclusividad de los productos lubricantes de Kendall. En 1952, vendió poco y tomó conciencia de la necesidad de contar con un gerente que pudiera «dar fuego» en la venta. Ese era Banchero. Un gerente que en efecto daría fuego en su papel de empleado de la empresa, pero que mantendría siempre como incentivo el «sombrero» de accionista, de propietario cada vez más omnipresente. El pequeño Lulo había crecido. Era un profesional, pero sobre todo un empresario. Un empresario que se haría grande, muy grande, hasta convertirse en líder de uno de los grupos económicos más importantes de América Latina.

\section{LA INCURSIÓN EN EL NEGOCIO PESQUERO}

Fue como director-gerente de Importadora Trujillo que Banchero se dio cuenta del crecimiento de un pequeño puerto al norte de Lima llamado Chimbote y del potencial que tenía allí la industria pesquera. El propio Banchero lo contó alguna vez con estas palabras: «Llegué a Chimbote el año 55, vendiendo lubricantes, lo cual me permitió tomar contacto con los pesqueros de la zona, que en ese tiempo eran unos pocos. Justamente, recuerdo cuando trataba de convencer al socio que tenía en el negocio de lubricantes de entrar a ese nuevo mundo de la pesquería, su asesor financiero le dijo que no creía en esa industria, que era como tomar estricnina ${ }^{65}$. Y es que Manucci había experimentado con la pesca. Y no le había ido bien. Pero su confianza en Banchero era tal que apostó con él en una primera inversión.

Esta primera incursión de Banchero en la pesca fue similar a la que cuarenta años después, en la década de 1990, harían en otro contexto una camada de nuevos empresarios pesqueros, a través de remates de fábricas que acreedores financieros veían como simple chatarra. Banchero, vio en dichos activos mucho más que chatarra. Hacia 1954, año en que falleció su padre en Tacna, se enteró del remate por el Banco Popular de una fábrica de conservas llamada Pesquera Chiclayo. Y la hizo suya.

A inicios de la década de 1950, la pesca a escala industrial era una industria naciente en el Perú. Pero era particularmente dinámica. Los inicios se habían dado durante la Segunda Guerra Mundial, cuando Japón y Escandinavia dejaron de abastecer al mercado de Estados Unidos. Se buscaba en particular pescado en conservas y aceite de hígado de

65 Cfr. Banchero 1967 a: 1. 
pescado (fuente principal de vitaminas A y D para las tropas norteamericanas) ${ }^{66}$. Pero tan pronto como en 1946, esta última necesidad desapareció con la aparición de un producto sintético alternativo, de manera tal que el desarrollo de la industria pesquera y la incursión de Banchero en ella, se inició fundamentalmente con la mira puesta en la fabricación de conservas de pescado para consumo humano.

Hacia 1950 había ya instaladas cuarenta y nueve fábricas. En 1955 el número había bajado a cuarenta y cinco. «La industria tuvo dificultades durante varios años hasta que en 1952-1954 los productores peruanos incursionaron exitosamente en el mercado británico, con bonito enlatado, y continuaron así la expansión. La renovada prosperidad atrajo a un grupo de nuevos empresarios de la clase media, entre los cuales se hallaba el futuro gigante de la harina de pescado: Luis Banchero Rossi ${ }^{67}$.

El gran auge, sin embargo, no llegó hasta que se descubrió en el mundo las bondades de la harina de pescado como alimento para animales. Antes, la Compañía Administradora del Guano, con el apoyo de la U.S. Fisheries, había intentado desarrollar el producto como fertilizante. Un fracaso. Y cuando hacia 1954, quedó claro su verdadero potencial como insumo proteínico para cerdos y aves de corral (después lo sería para maricultura), «...la estupidez de la Compañía Administradora de Guano estuvo a punto de liquidar la pesca ${ }^{68}$. En efecto, temerosa del peligro ecológico para las aves guaneras, dicha compañía estuvo a punto de lograr la prohibición de pesca de anchoveta. En el furor de dicho debate «entre industriales y burócratas... Luis Banchero Rossi apareció en Chimbote a instalar la cuadragésima sexta fábrica de conservas del Perú. Se llamaba Florida ${ }^{69}$.

Los primeros años fueron duros. De siete días de trabajo a la semana, de dieciocho horas por día. Sus peripecias para bajar la primera chimenea sin grúa son relatadas por Thorndike en detalle. Sus idas y venidas de Trujillo a Lima. Su negociación con cada pescador, con cada futuro gerente de su organización.

A falta de flota, las primeras batallas de Banchero fueron para obtener pescado en el puerto. Utilizaba todas las estrategias posibles para hacer de la pesca del día insumo para su fábrica. Pero la más común era la más simple: ofrecer mejor precio a los pescadores, sacrificar margen y ganar en volumen.

No había pasado un año de funcionamiento de Florida y fallecía Manucci. Los herederos del connotado empresario trujillano, prefirieron mantener el negocio de los lubricantes y canjearon con Banchero sus acciones de dicho negocio por su participación en la conservera. Así, en 1956, Luis Banchero Rossi se convirtió en el único propietario de lo

66 Cfr. Thorp y Bertram 1985: 272.

67 Cfr. Thorp y Bertram 1985: 272 y 371.

68 Cfr. Thorndike 1973: 88.

69 Cfr. Thorndike 1973: 89. 
que fue el embrión de su futuro imperio.

Ese mismo año, Banchero adquirió su primera embarcación pesquera que, por supuesto, no era cualquier embarcación. La Roxana, adornada de los colores de la bandera italiana, ingresó a puerto como la bolichera más grande de Chimbote. Luego, vino Pez Volador, adquirida a Eugenio Barman. Siguieron, Hércules, Santa Isabel, hasta que apareció la Fiorina, enorme embarcación con motor Caterpillar que se iba a dedicar exclusivamente a la anchoveta. Finalmente, La Tacna, primera embarcación de acero, hizo su ingreso a Chimbote. De esta manera, Banchero empezó a actuar por todos los frentes. Pescando, procesando, comercializando. Y contratando gente de otras empresas más grandes ofreciéndoles mejores condiciones de trabajo.

A pesar de los múltiples enemigos que se iba haciendo conforme ganaba las batallas de la competencia, Banchero sembraba lealtades, gerentes incondicionales, capitanes de barco a los que trataba con respeto y humildad, competidores que poco a poco le fueron temiendo y apreciando a la vez. Especuladores internacionales que intentaron quebrarlo y terminaron rindiéndose a sus pies.

\section{EL BOOM DE LA HARINA DE PESCADO}

«Del 55 en adelante — contó el propio Banchero en un discurso- fueron años maravillosos, años donde la única meta que teníamos todos era producir ${ }^{70}$. El Perú pasó de producir unas quince mil toneladas de harina de pescado en 1955 a cerca de quinientas mil toneladas a inicios de la década de $1970^{71}$. La introducción de las redes de nailon fue un salto tecnológico esencial para el crecimiento de la industria ya que permitieron pescar a mayor escala. En 1954, había diecisiete fábricas que producían harina de pescado en el Perú. En 1959, sesenta y nueve. En 1963, ciento cincuenta y cuatro. En 1964, el Perú producía el 40\% de la oferta mundial de harina de pescado. De 1965 a 1969, se exportó en promedio doscientos ocho millones de dólares al año, lo que representaba cerca de un tercio del valor total de las exportaciones peruanas.

La fortuna de Banchero creció a un ritmo similar. En 1957 se asoció con Wilbur Ellis, empresa estadounidense que había sido pionera en el negocio en el Perú. El primer objetivo fue instalar una planta de harina de pescado, llamada Pesquera Humboldt, con una capacidad de producción de diez toneladas por hora ${ }^{72}$. Muy a prisa, Banchero buscó duplicar la producción. El ritmo de crecimiento y el endeudamiento asociado, no correspondía con las políticas conservadoras de una corporación como Wilbur Ellis. Una vez más, Banchero optó por comprarles a sus socios su participación accionaria, con un pago

70 Cfr. Banchero 1967a: 1.

71 Cfr. Banchero 1967a: 2.

72 Cfr. Arévalo 1995: 87-88. 
a cuenta de cuando hubiese producción. Cuando llegaron años de abundancia, no solo saldó su deuda, sino que expandió su capacidad de pesca y de producción con la compra de más barcos y bolicheras, así como la instalación de plantas en Chimbote, Supe, Callao, Chicama y Paracas ${ }^{73}$. Y es que, paralelamente, Banchero había fundado Compañía Pesquera Los Ferroles — su tercera empresa pesquera — junto con la empresa yugoslavaamericana Star Kist. Pero esta vez, desde un inicio, Banchero fue accionista mayoritario, además de gerente general. Después de Ferroles, que iba a convertirse en la fábrica más moderna del litoral, Banchero compró Exportadora Industrial Callao S. A., empresa que serviría para operaciones financieras y como armadora de barcos ${ }^{74}$. Para cuando adquiría el control de Humboldt a Wilbur Ellis, las empresas de Banchero empezaban a parecerse a una corporación, con oficinas contables y departamento de exportaciones, además de serias perspectivas para poner una sucursal en Hamburgo, la que sería Humboldt Internacional. Muy pronto fue necesaria la oficina en Lima, que abriría primero en el edificio El Sol y luego en el edificio Internacional, en La Colmena.

Banchero constituyó paso a paso una organización empresarial con la tecnología y los conceptos de gerencia más modernos de su tiempo. Para el lector de hoy puede parecer sorprendente cómo varios recuentos biográficos del industrial destacan que sus empresas contaran con una computadora IBM 360 dándole soporte a sus operaciones ${ }^{75}$. El paso final fue obviamente la constitución de una holding para controlar y gestionar la mayor parte de sus intereses relacionados con la pesca, al cual llamó Operaciones y Servicios S. A. (Oyssa), con una gerencia general que delegó y una planilla de ejecutivos profesionales de su más alta confianza. Paulatinamente, Banchero empezó a liderar el sector, presidiendo el Consorcio Pesquero —alianza de productores locales para enfrentar los retos de la comercialización-, la Sociedad Nacional de Pesquería, y participando de directorios de dos bancos.

\section{LA DIVERSIFICACIÓN DE LOS NEGOCIOS}

La energía empresarial de Banchero no tenía límites. De manera paralela a la expansión de su grupo centrado en el negocio harinero, incursionaba en otros negocios. Parte importante de su expansión empresarial fue la incursión en la construcción de barcos, la cual según Thorp y Bertram fue el caso «más espectacular de encadenamiento hacia atrás» del sector exportador peruano en la época. «En 1957, se construyeron seis embarcaciones para la pesca de anchoveta; en 1960, la cifra de producción fue de 305 y, en 1963 (después de la recesión de 1961) alcanzó el máximo de 453... Tanto en la construcción de embarcaciones como en la elaboración de harina de pescado, la firma líder local a fines de

73 Cfr. Arévalo 1995: 88.

74 Cfr. Thorndike 1973: 167.

75 Cfr., por ejemplo, Arévalo 1995: 86, 90. 
la década de 1960 fue la de Luis Banchero» ${ }^{76}$.

En 1963, había vuelto a emprender uno de sus negocios originales, el de envasado de alimentos, pero esta vez en gran escala, con la fundación de una empresa llamada Envasadora San Fernando, donde se enlataba, además de bonito, frutas, vegetales y carnes. Banchero tuvo también intereses empresariales en negocios como la metalurgia, la minería, los seguros, el transporte marítimo y la publicidad. A los treinta años se volvió accionista y director del Banco de Crédito y, un año antes de morir, poseía el $25 \%$ de este ${ }^{77}$.

Su incursión en el negocio de la prensa escrita le generó aun más notoriedad y sin duda poder político. Y, a la larga, fue el negocio que más perduró en el tiempo. La aventura periodística la inició Banchero con uno de los periodistas más singulares que ha conocido el Perú: Raúl Villarán Pasquel, quien años después sería bautizado como «El Rey de los Tabloides» ${ }^{78}$. Villarán fue un verdadero «animal» del periodismo. No había cumplido dieciocho años y ya le estaba proponiendo a don Augusto Belmont utilizar su imprenta para sacar una revista deportiva, con la ambición de lograr un tiraje cercano al del diario El Comercio. «¡Veinte mil, señor Belmont! ¡La gente está cansada de los políticos! ¡La vida, señor Belmont, toda la vida en tinta y papel, los héroes dominicales, la risa y el júbilo de cada pequeña victoria en los estadios, las voces de la popular! ¡Los jóvenes no tienen lectura propia en este país, señor Belmont! ${ }^{79}$. Villarán inventó la prensa popular, lo que hoy se conoce como «prensa chicha» y que vende más que la prensa seria en el Perú. Fue sin duda un precursor, un emprendedor de la prensa escrita, un visionario como pocos. $\mathrm{Y}$ es que hoy, todos los grupos editoriales, empezando por El Comercio (con su tabloide Trome) tienen como principal publicación en términos de tiraje un tabloide popular. Sin duda, el titular más célebre y que marcó un hito en la carrera de Villarán fue el titular de Última Hora (que pertenecía a La Prensa de Pedro Beltrán) del 13 enero de 1950, a propósito de la guerra de Corea: «Chinos como cancha en el paralelo 38». Tenía veintidós años de edad.

Al más puro estilo de los contemporáneos Añaños, Banchero decidió iniciar esta empresa en casa. Los inicios fueron difíciles. Cuenta Juan Gargurevich ${ }^{80}$ que a Banchero y Villarán los habían estafado con los equipos destinados al diario de Tacna, que llamaron en un inicio Sur. No soportaban el tiraje y Banchero empezó perdiendo plata. En reali-

76 Cfr. Thorp y Bertram 1985: 272 y 386.

77 Cfr. Arévalo 1995: 88.

78 Caretas reproduce un extracto del libro de Thorndike 2008.

79 Extracto de libro de Thorndike, Caretas, 11 de setiembre de 2008.

80 Cfr. Gargurevich 2008, http://blog.pucp.edu.pe/item/18060. 
dad, parece que siempre perdió plata con Villarán, quien como buen periodista antiguo, era un bon vivant. Despilfarrador, culto, seductor e irresponsable con el dinero. Gargurevich fue uno de los contratados por Villarán para encargarse del que sería el Correo de Tacna. Para el lanzamiento del Correo de Lima había sido contratado un ejército de periodistas, entre los que destacaban los jóvenes periodistas Thorndike e Higashi. Correo de Lima apareció el 10 de junio de 1963. Luego Correo de Arequipa, Correo de Huancayo y Correo de Piura. Toda una osadía.

En su momento, Correo fue un fiasco económico para Banchero. Ante tanto despilfarro, aceptó la renuncia de Villarán y la dirección pasó a Mario Castro Arenas, luego a Roberto Ramírez del Villar. Gargurevich sostiene que detrás de la renuncia de Villarán hubo un conflicto entre la independencia periodística que este defendía y el lobby pesquero que se sentía incómodo con el díscolo periodista. Esto no queda claro. Sobre todo si en 1967, Banchero volvió a contratar a Villarán, quien aceptó encantado lanzar una nueva publicación de Epensa: el diario Ojo. El 14 de marzo de 1968, el diario de color verde apareció con el siguiente titular: «LA VERDAD... SR. PRESIDENTE, ESTO ESTÁ CORROMPIDO».

Hoy cuarenta años después Epensa goza de buena salud, económica y periodística. Correo y Ojo siguen circulando con sus colores originales, rojo y verde. La dirección de la empresa está a cargo de Luis y Enrique Agois Banchero, hijos de don Enrique Agois y de Olga, la hermana de Luis Banchero Rossi.

\section{«SAlto de ObSTÁCUlOS»: LOS ESPECUlADORES, EL ESTADO Y EL MAR}

La expansión empresarial de Banchero, concentrada en la producción y comercialización de la harina de pescado, fue espectacular. Como lo ha sido más recientemente el crecimiento de aventuras empresariales tan importantes como la de la familia Añaños, con el grupo Aje (Kola Real, Big Cola), o la familia Flores, con Topy Top ${ }^{81}$. La diferencia más importante entre estas historias y la de Banchero solo ha sido la época, lo cual no es poca cosa. Y es que, a diferencia de los Añaños y los Flores, Banchero tuvo que enfrentar, junto con sus competidores, a una serie interminable de obstáculos. Los más importantes fueron sin duda tres: el de los especuladores, el de la naturaleza y el del Estado.

Banchero y el resto de pioneros pesqueros debieron aprender en sus primeros años de auge una primera y dolorosa lección: no solo bastaba batir récord de producción sino que también había que aprender a comercializar la harina de pescado. «Aprendimos que si la comercialización no se hacía ordenadamente, podía suceder como sucedió en el año 60, que los precios de venta de la harina de pescado cayeron de niveles sobre los 100 dólares (valor FOB puerto peruano) a niveles del orden de los 55 y 52 dólares $\mathrm{FOB}{ }^{82}$, recalcó

81 Ver Córdova 2008.

82 Cfr. Banchero 1967b: 1. 
Banchero en un discurso ante una comisión especial encargada de revisar la legislación pesquera en la Cámara de Diputados de ese entonces. Hasta entonces, los comerciantes europeos habían logrado mantener divididos a los productores peruanos. El objetivo: ampliar al máximo los márgenes a su favor. Los productores buscaron rebelarse, pero no les fue fácil: los compradores de harina estaban fragmentados y, sobre todo, no confiaban en los peruanos. No los consideraban serios. Toda una odisea y muchos viajes le costaron a Banchero abrir directamente los mercados en Nueva York y en Hamburgo. Y luego en los países socialistas en los que nadie había pensado antes.

En un artículo de la revista La Olla se cuenta la historia de la incursión en los mercados de detrás de la Cortina de Hierro: «Invierno de 1961. Un hombre alto, gordo, melenudo y con enormes patillas, llevando por único equipaje un maletín negro, cruzaba la frontera de Alemania Oriental. Enfundado en un grueso abrigo de piel, llegó a Varsovia. Voló a Moscú. Entró al Kremlin. Visitó apartadas zonas rurales, donde se levantan los koljoses modelo. Desplazándose silenciosamente, estuvo en las dependencias del comercio exterior soviético. Días después llegaba a Hamburgo y enviaba un corto télex a Lima. En los puertos peruanos empezó una actividad febril. Docenas de miles de toneladas de harina de pescado embarcadas con destino a Alemania. Desde Hamburgo, la harina de pescado era redespachada a los países socialistas. Lo dólares rojos, dólares al fin y al cabo, salían de Moscú y por la vía de Hamburgo comenzaron a llegar a Lima... El hombre de las patillas largas viajaba a Praga, Budapest, Moscú, Hamburgo, París. Año tras año, este comercio lícito pero secreto, prosperaba» ${ }^{83}$.

Paralelamente, bajo el impulso de Banchero, los productores peruanos impulsaron, en el seno de la Asociación Internacional de Productores de Harina de Pescado, la formación de una institución denominada Fish Meal Export Organization (FEO), para intercambiar información sobre datos de producción de los países exportadores y stocks en los importadores. Banchero siempre advertía que en ella no se concertaban, discutían ni fijaban precios $^{84}$. Asimismo, se conformó una suerte de cooperativa de ventas llamada Consorcio Pesquero, que llegó a agrupar el 92\% de la producción local de harina de pescado. El objetivo de este órgano era comercializar unificadamente el producto peruano en todos los mercados y hacer un cumplir un recién instaurado sistema de cuotas de exportación por nivel de producción ${ }^{85}$. Al cabo de un tiempo, entonces, se venció el obstáculo de los especuladores. La comercialización había sido controlada.

Un segundo obstáculo que Banchero tuvo siempre que enfrentar fue el de la naturaleza. Más allá de los accidentes de ruta, como el hundimiento de algunas naves que Ban-

83 Cfr. Arévalo 1995: 89.

84 Cfr. Banchero 1967b: 1.

85 Cfr. Banchero 1967b: 2. 
chero se apuraba en rescatar del fondo del mar, el principal escollo natural que la industria pesquera tardó en aprender a controlar fue el del manejo ecológico del recurso. Por una parte, durante esta primera era de auge pesquero, las empresas no llegaron a aprender a prever la eventualidad de un Fenómeno de El Niño. Lo que hoy podemos observar en coloridas imágenes satelitales, era aún un evento poco conocido. Se había experimentado en 1925, 1941, 1953 y 1957. Nadie esperaba en 1965, cuando la industria estaba en pleno auge de expansión, que asistiéramos a una auténtica catástrofe para las empresas pesqueras que, en su mayoría, había crecido sobre la base de endeudamiento. Para 1966, la mayoría estaba quebrada y ejecutada por los bancos. Banchero quedó mejor parado que el resto. Pero la industria ya estaba herida de muerte. Y es que, por otra parte, lo que quedó claro en los años siguientes es que esta industria requería de un sistema de regulación a fin de evitar la depredación del recurso. Como lo han señalado Thorp y Bertram, hacia 1970-1971 la capacidad de procesamiento de la industria era de treinta millones de toneladas anuales, asumiendo trescientos días útiles. Hacia 1972, cuando sobrevino un nuevo Fenómeno del Niño, se capturaba alrededor de diez millones de toneladas. Fue el año en que el Perú amaneció desconcertado con el asesinato de Luis Banchero Rossi. Fue el año en que la pesca empezó una agonía que duraría casi dos décadas.

El tercer obstáculo, probablemente aquel que más daño le hizo a la expansión del grupo Banchero, fue el de las trabas burocráticas y la angurria tributaria del Estado. La industria casi no nace por la oposición de la Compañía Administradora de Guano. Luego vino la creación de un sinnúmero de trámites y permisos para poder operar. Todo demoraba más de la cuenta por el simple hecho de tratarse de una industria nueva y porque el Perú ingresaba poco a poco al más nefasto periodo estatista del siglo XX. El Callao era el puerto más caro del mundo y la industria pesquera la más gravada del país. El colmo fue cuando en determinado momento se exigió que capitanearan los barcos oficiales de la Marina de Guerra. Todo un fiasco. Los tenientes de guerra fueron incapaces de capitanear bolicheras. Al poco tiempo, luego de varios incidentes, dicha absurda medida tuvo que ser revertida, como tuvieron que ser derogados en 1966, el año de la crisis posterior al Niño, la ley de 1963 que gravaba de manera extraordinaria las exportaciones pesqueras por encima de otras industrias de exportación. Esto en el marco de un incremento de costos asociado a la inflación galopante, producto de los excesos de emisión monetaria y déficit fiscales ${ }^{86}$. La estatización de las empresas pesqueras y la formación de Pesca Perú por el gobierno de Juan Velasco Alvarado fue el tiro de gracia. En 1972, Luis Banchero había muerto. En 1972, la industria pesquera había muerto.

Tuvieron que pasar casi veinte años para que de entre las chatarras de Pesca Perú apareciera una nueva generación de «capitanes de industria pesqueros». Austral de González y 
Tramontana, Hayduk de los Martínez y los Baraka, Diamante de los Ribaudo, Copeinca de los Dyer, Sipesa de Galsky (luego adquirida por los Brescia, que fundan Tecnológica de Alimentos TASA), Exalmar de Matta, y otros más. Pero esta vez, a diferencia de la década de 1960, las empresas aprendieron del Niño de 1998 y «modelaron» en sus proyecciones financieras la eventualidad de un Niño. Esta vez, finalmente, en el 2008, el Estado logró imponer un sistema de cuotas individuales por empresa, el cual, sumado a un moderno sistema de control satelital, garantiza una explotación racional del recurso pesquero. Banchero debe estar sonriendo desde arriba.

\section{El Hombre}

Luis Banchero Rossi fue más que un empresario. Fue un ícono del empresariado. Más culto que la mayoría, se dice que era un gran lector de literatura, cosa no muy común en las clases altas peruanas. En él, se dice, convivían la elegancia y la humildad. «Luis Banchero era un hombre pulcro, elegante. Vestía muy bien, pero según sus amigos más íntimos nunca se le subieron los humos a la cabeza. Siempre fue simple y a menudo conversaba con los hombres más modestos de sus organizaciones» ${ }^{87}$, escribió sobre Banchero el diario El Comercio, luego de su muerte. «Banchero hablaba poco de sí mismo», señaló «Suceso», el suplemento dominical de Correo, uno de los periódico que él fundó. «Pero cuando lo hacía, era rotundo» ${ }^{88}$, agregaba la publicación. Alguna vez le preguntaron si era el industrial pesquero más grande del Perú y lo negó rotundamente. Era el más grande del mundo.

Nunca se casó. No tuvo hijos. Probablemente por falta de tiempo. Era dadivoso como buen genovés. Su familia y sus amigos le rendían pleitesía. Lo creían inmortal. Por lo menos a sus cuarenta y dos años. Su abrupta muerte — no era para menos - sorprendió a propios y extraños. Después de su asesinato se habló mucho. Sobre todo alrededor del juicio en donde se involucró al hijo de su jardinero, Juan Vilca, y a su secretaria Eugenia Sessarego.

Recuerdo como si fuera ayer el día en que a mis seis años recién cumplidos, mientras mi padre dormía la jarana de Año Nuevo, leí el titular de El Comercio que anunciaba el asesinato de Luis Banchero Rossi. Son varias las generaciones que crecimos fascinados con este personaje que muy pronto se convertiría en una auténtica leyenda de la historia empresarial del Perú. Somos varios quienes empezando nuestra década de los cuarenta, aún no nos creemos que hemos llegado a la edad que tenía El Hombre, como lo llamaban sus allegados, cuando lo hallaron muerto en Chaclacayo.

87 Cfr. El Comercio, enero de 1972.

88 Cfr. Correo, enero de 1972. 


\section{Bibliografía}

ARÉVALO ALVARADO ZAÑARTU, Alfonso (1995) Historia y fundamentos de la pesquería en el Perú. Lima.

BANCHERO ROSSI, Luis (1967a). Exposición ante la comisión especial revisora de la legislación pesquera ante la Cámara de Diputados. Lima.

- (1967b). Discurso ante la Asociación de Dirigentes de Ventas. Lima.

BARDELLA, Gianfranco (1989). Un siglo en la vida económica del Perú 1989-1999. Lima: Banco de Crédito del Perú.

CÓRDOVA, Daniel (2008a). «Amid Hopelessness, Hopeful Investment: The Case of the Añaños Family and Kola Real». En: Lessons from the Poor. Triumph of the Entrepreneurial Spirit, editado por Álvaro Vargas Llosa, The Independent Institute.

(2008b). «Defeating Poverty Doing Business: The Case of the Flores Family and Topy Top». En: Lessons from the Poor. Triumph of the Entrepreneurial Spirit, editado por Álvaro Vargas Llosa, The Independent Institute.

GARGUREVICH, Juan (2008). Raúl Villarán: «Soy el mejor», Blog Periodismo-Periodistas. http://blog.pucp.edu.pe/item/18060.

KEYNES, John M. (1936). Teoría general de la ocupación, el interés y el dinero. México D. F.: Fondo de Cultura Económica.

SALAZAR, Eduardo (2008). Tacna y los inmigrantes italianos. http://inmigracionsigloxix. blogspot.com/2008/10/tacna-y-los-inmigrantes-italianos.html.

SCHUMPETER, Joseph (1912). Teoría del desarrollo económico. México D. F.: Fondo de Cultura Económica.

THORNDIKE, Guillermo (1973). El Caso Banchero. Barcelona: Barral Editores.

THORP, Rosemary y BERTRAM, Geoffrey (1988). Perú, 1890-1977: crecimiento y politicas en una economía abierta. Lima: Mosca Azul y Fundación F. Ebert.

VON MISES, Ludwig (2001). La acción humana. Tratado de economía. Madrid: Unión Editorial, sexta edición.

\section{Hemerografía}

CORREO (1972). Enero.

EL COMERCIO (1972). Enero.

LA PRENSA (1972). Enero.

A Mario Vargas Llosa el ejercicio del poder de manera autoritaria le causa desconfianza desde su juventud revolucionaria. Señala que es «alérgico» a ese fenómeno, debido al visceral rechazo que siente por toda clase de dictadura; ello no impide, sin embargo, que la política, el poder y la libertad sean aspectos medulares en gran parte de su obra; motivo que nos induce a examinar a este peruano universal desde esa óptica, quizá ayudándonos a responder la pregunta — tantas veces repetida - que se hace Zavalita en Conversación 



\section{Mario Vargas Llosa \\ (1936- )}

\section{Pedro Cateriano Bellido (Compilador)}



en La Catedral y que muchos se formulan en momentos de desaliento nacional.

Vargas Llosa nace en Arequipa en 1936. Antes de cumplir un año es llevado a la casa de sus abuelos maternos, en Cochabamba, Bolivia. En 1946, su abuelo Pedro Llosa es nombrado prefecto de Piura, durante el gobierno de José Luis Bustamante y Rivero, y vuelve al Perú con la familia. En la ciudad norteña concurre al Colegio Salesiano; al año siguiente viaja a Lima y estudia en La Salle hasta los catorce años; luego es matriculado en el Colegio Militar Leoncio Prado, un internado para adolescentes de las distintas capas sociales de todo el país que, en un ambiente de cuartel, le descubre aspectos de la sociedad peruana que hasta ese entonces él ignoraba. La experiencia es tan brutal que la utiliza como tema básico en su primera novela.

En 1952, año en que regresa a Piura a concluir la secundaria en el Colegio Nacional San Miguel, participa en la organización de una huelga para evitar que los exámenes finales sean tomados de improviso y se hace conocer por primera vez como autor, estrenando La huida del inca, pieza teatral de la que dan noticia periódicos piuranos y limeños. Ambos acontecimientos son emocionantes para él, pero otro lo conmueve más: leyendo La noche quedó atrás, de Jan Valtin, queda vivamente impresionado por el descubrimiento de la magnitud de las formas de gobierno, la injusticia, el abandono y la urgencia de una revolución, descritos en el libro. El remezón lo deja meditando largamente.

Continúa en el diario La Industria, su actividad periodística comenzada a los quince años en La Crónica de Lima; mientras, la política entra en su vida «al galope y con el idealismo y la confusión con que suele irrumpir en un joven ${ }^{89}$. Uno de sus tíos, Luis Llosa, escucha, con paciencia sus inquietudes y lo pone al tanto de lo que son y qué se proponen las principales corrientes ideológicas del país. Es cuando empieza a advertir con claridad el drama nacional con sus desigualdades, injusticias, racismo y privilegios. Toma conciencia de la necesidad de intervenir en el cambio de esa situación y estima que la mejor vía es a través del socialismo y la revolución. Finalizado el colegio, decide iniciar sus estudios superiores de Letras y de Derecho ${ }^{90}$ en la Universidad Nacional Ma-

89 Cfr. Vargas Llosa 1993: 203.

90 Pronto constató que la abogacía no era lo suyo. 
yor de San Marcos, «la de los cholos, ateos y comunistas»" ${ }^{91}$, descartando la Universidad Católica, que habría sido su destino natural.

En la universidad, aunque decidido a anteponer el curso de literatura sobre las demás materias, asiste a las clases magistrales de historia del profesor Raúl Porras Barrenechea, que lo deslumbran haciéndolo dudar por un momento de su verdadera vocación, aunque sin dificultarle seguir encandilado con las ideas del socialismo. San Marcos es un centro de vigorosa oposición a la dictadura del general Manuel A. Odría. Se aproxima a los alumnos de izquierda, integrándose al grupo Cahuide, célula con la que el Partido Comunista se organiza allí, y se siente a sus anchas participando en manifestaciones contra el autócrata.

Son años en que su admiración por Jean-Paul Sartre y la tesis acerca del compromiso social lo galvanizan. La literatura como vocación, en ese momento, se le torna compulsiva. Instituye al escritor francés como su guía.

Al finalizar el Ochenio odriista, surge la Democracia Cristiana y presume que se ha fundado para que el ex presidente Bustamante y Rivero, conspicuo jurista y ejemplo de integridad, la encabece. Al constituirse como partido, se inscribe en él. Más tarde dirá que, al abrazar el social cristianismo, «su entusiasmo político era mayor que su coherencia ideológica ${ }^{92}$. La doctrina social de la Iglesia y sus encíclicas le parecen conservadoras y pronto pierde el interés en ellas; no renuncia, sin embargo, al partido, pero años después, desde Europa, se aparta.

Muy joven se casa con Julia Urquidi. Para sostener el nuevo hogar, busca los medios económicos indispensables, desempeñando conjuntamente hasta siete ocupaciones. Una de ellas vinculada a la política: redacta los discursos del candidato presidencial conservador Hernando de Lavalle, en $1956^{93}$.

Al culminar sus estudios obtiene una beca en España. Se hace realidad su gran anhelo de viajar a Europa para ser escritor, pero no concibe esa posibilidad sin vivir en París. Con la ayuda de su admirado profesor Raúl Porras Barrenechea, gestiona otra beca en Francia, pero sin lograrla. Sin embargo, no se arredra y viaja a ese país acompañado de su esposa. Viven momentos cruciales de estrechez que lo obligan a redoblar su búsqueda de «trabajos alimenticios». Son años en que lee apasionadamente y anota con minuciosidad los descubrimientos que obtiene en los libros de dos novelistas que tendrán influencia capital en su obra: Faulkner y Flaubert.

La estada en el Viejo Mundo amplía notablemente su cultura y lo estimula a man-

91 Cfr. Vargas Llosa 1993: 203.

92 Cfr. Vargas Llosa 1993: 203.

93 Lavalle perdió el apoyo de la Democracia Cristiana porque dijo que continuaría la patriótica obra de Odría. Mario Vargas Llosa, quien advirtió de su colaboración con Lavalle a los democristianos y quiso renunciar, como la mayoría de ellos, votó en esas elecciones por Fernando Belaunde. 
tener viva la pasión de escribir. Satisface sus anhelos buscando sin desmayo los tiempos libres para ocuparse en lo suyo, optando literalmente por la avaricia de un horario de trabajo solo para él. Son innumerables los trascendidos al respecto; para muestra un botón: con algunos compañeros de ruta hace un viaje a Tarragona, lugar en el que veraneaba Carlos Barral, apenas llegan, sin poder resistir el calor infernal, corren al agua todos... menos Vargas Llosa. Cuando más tarde, uno de ellos nota su ausencia, vuelve al alojamiento para saber qué le ha sucedido, y lo encuentra «escribiendo mientras la infame turba de escritores que rodeaban a Barral, gozaba del mar y la francachela entre carcajadas y jocosos cometarios sobre lo divino y lo humano» ${ }^{94}$.

Después de tres años intensamente laboriosos, publica su primera novela, La ciudad y los perros, que obtiene, por unanimidad, el Premio Biblioteca Breve 1962 (además el de la Crítica española y el segundo puesto del Formentor 1963). Al concedérsele el galardón, José María Valverde, miembro del jurado, declara: «Es la mejor novela de lengua española desde Don Segundo Sombra» ${ }^{95}$ y Carlos Barral: «Es una de las mayores y más estimulantes sorpresas en mi carrera de editor $»^{96}$. La resonancia internacional del acontecimiento y la inmediata traducción del libro a los más diversos idiomas, lo lanzan a la fama antes de habérselo imaginado ${ }^{97}$.

Como muchos intelectuales, está fascinado por la Revolución cubana. Después recordará: «Desde la perspectiva de un latinoamericano, la idea de justicia, de liberación y de progreso, pasaba por la izquierda. Parecía pasar por la izquierda. El socialismo se veía como un ideal generoso y libertario» ${ }^{98}$. Viaja a Cuba en cinco oportunidades, la primera en misión periodística, pero las posteriores, como simpatizante del régimen. Conoce a Fidel Castro, que lo impresiona por su carisma y personalidad abrumadora.

A poco tiempo, con similares o mayores elogios, la novela La Casa Verde (1966) merece el Premio Rómulo Gallegos, el principal de América Latina (1967). El discurso

—La literatura es fuego»- que pronuncia al recibirlo es memorable, no solo para la izquierda, por su idealismo revolucionario y enérgica rebeldía ${ }^{99}$. Vargas Llosa deja los trabajos nocturnos de la radiodifusión y televisión francesa y

94 Relatado por el novelista Juan García Hortelano a Armas Marcelo. Cfr. Armas Marcelo 2002: 36.

95 Cfr. Valverde 1963.

96 Cfr. Armas Marcelo 2002: 37.

97 En Lima, mil ejemplares de la novela son quemados públicamente en el Colegio Militar Leoncio Prado. Este acto primitivo, muy publicitado, contribuye aún más al éxito del libro.

98 Cfr. Halperín 1997: 256.

99 A través de Olivo Carpenter, le pidieron que donara el premio a la Revolución cubana con el ofrecimiento de que luego lo compensarían. La propuesta le causó repugnancia y por supuesto la rechazó. 
los de la agencia de noticias France-Presse, para viajar a Lima por un breve periodo. Se casa con Patricia Llosa ${ }^{100}$ y retorna a Europa. Huyendo de la fama, se traslada a Londres, recupera su anonimato y trabaja como traductor de la Unesco y profesor en colegios y universidades.

Una oferta de Carmen Balcells, su agente literaria, lo decide a dejar la enseñanza y sus otras tareas, y se muda a Barcelona en 1970, para dedicarse plenamente a acrecentar su labor creadora en la tranquilidad largamente soñada. Periódicamente, por temporadas cortas, continuará visitando el Perú.

Sus éxitos coinciden con la aparición de una pléyade brillante de escritores de América Latina, que llama la atención en todo el mundo y que la crítica y los editores dan a conocer como el boom. Lo conforman, además de él, Gabriel García Márquez, Julio Cortázar y Carlos Fuentes. Más tarde se agregarán los nombres de novelistas anteriores a ellos (Juan Rulfo, Juan Carlos Onetti, Alejo Carpentier) o posteriores (Guillermo Cabrera Infante, José Donoso, Manuel Puig y otros). Las traducciones y ediciones se multiplican superando, por primera vez, a las de autores europeos o norteamericanos.

En el mundo se producen acontecimientos abusivos, la mayoría perpetrados por la Unión Soviética. Uno de ellos es contra Checoslovaquia, donde Alexander Dubcek ha iniciado la conocida «Primavera de Praga», impulsando reformas democráticas. La Unión Soviética ve en ellas una amenaza a su hegemonía y, sin más ni más, la invade a sangre y fuego. Fidel Castro no vacila en respaldar el abuso: Vargas Llosa, en cambio, lo critica abiertamente en un artículo que da la vuelta al mundo: «El socialismo y los tanques» ${ }^{101}$.

Después se difunde la noticia de que el poeta cubano Heberto Padilla ha sido encarcelado porque su obra es juzgada contrarrevolucionaria. Vargas Llosa redacta entonces un manifiesto, condenando el acto, que de inmediato firman numerosos escritores. Padilla es liberado, pero luego de una obligada retractación ${ }^{102}$.

Convencido de que el modelo cubano y el de las llamadas democracias populares, encabezadas por la Unión Soviética, no son la opción para alcanzar y garantizar la libertad del hombre que él defiende en todas sus manifestaciones, hace público su desencanto del marxismo y del comunismo. Vargas Llosa recupera su libertad. De inmediato, la maqui-

100 Ella asume desde entonces la abrumadora tarea de manejar su agenda de ciudadano del mundo. Es clave para que Mario Vargas Llosa realice su labor creadora con absoluta tranquilidad y sin preocuparse de detalles administrativos.

101 Este fue el último intento, para lograr cambios democráticos, dentro del sistema socialista. Luego se impuso el comunismo totalitario en todos los países detrás de la Cortina de Hierro y consumó inimaginables crímenes.

102 El novelista chileno Jorge Edwards se pregunta si el joven escritor era realmente un marxista; si efectivamente podía admirar a Flaubert, novelista que destaca la individualidad y la libertad, y simultáneamente defender los ideales de la Revolución cubana. Había una incompatibilidad intelectual e ideológica, que empezaba a atormentarlo... 
naria izquierdista lo ataca llenándolo de injurias e improperios.

En el Perú, la mayoría proviene de los que secundan servilmente las dictaduras de Velasco y Morales Bermúdez. A ellos, que se han multiplicado hasta formar una sorprendente mayoría, Vargas Llosa les enrostra en innumerables ocasiones su conducta de «intelectuales baratos», subrayando que ellos «tuvieron tanta responsabilidad como los militares en lo ocurrido en el Perú en aquellos años, sobre todo, en los primeros siete — de 1968 a 1975, los de Velasco_- en los que se adoptaron todas las soluciones equivocadas, para los grandes problemas nacionales, agrandándolos y precipitando al Perú en una ruina a la que Alan García daría la última vuelta de la tuerca. Aplaudieron la destrucción por la fuerza del sistema democrático, que, por defectuoso e ineficiente que fuera, permitía el pluralismo político, la crítica, la vida sindical y el ejercicio de la libertad ${ }^{103}$.

Congruente con el cambio de parecer que le han suscitado esos acontecimientos, reconsidera algunos de sus juicios valorativos, entre ellos, su adhesión al modo de pensar de Sartre, que cree en el «escritor comprometido» políticamente, y opta por la línea individualista, que defiende la libre participación cívica, dejando de lado el interés ideológico, que ha emprendido Albert Camus, adversario intelectual del otro autor existencialista.

Y, así como ha demorado para desengañarse de la Revolución cubana, su acercamiento a las ideas liberales ocurre también en un lento proceso de análisis. En 1979 participa en Lima en una conferencia organizada por el Instituto Libertad y Democracia, acerca de la economía de mercado. Allí conoce a Friedrich von Hayek, insigne liberal austriaco, que domina tanto la economía como el derecho, la historia, la política, la ética y la filosofía, que despierta en él viva atención por las ideas que expone acerca del liberalismo.

Hasta ese momento Vargas Llosa se considera un social demócrata; recién a través de Raymond Aron comenzará a acercarse al pensamiento liberal. En Washington lee con interés creciente a Karl Popper, a Hayek y a Isaiah Berlin, intelectuales que lo aproximan más hacia esa corriente ${ }^{104}$. De estos autores le atrae la defensa del individuo contra el Estado.

Acaso una de las experiencias que inclinan su adhesión hacia el liberalismo provenga del hecho de haber vivido en Inglaterra durante el gobierno de la primera ministra, Margaret Thatcher, cuya administración de once años considera «la revolución más fecunda que haya tenido lugar en la Europa de este siglo ${ }^{105}$ y la de efectos más contagiosos en

\footnotetext{
103 Cfr. Vargas Llosa 1993: 311.

104 Más tarde llegará a decir que si tuviera que nombrar los tres pensadores modernos a los que más les debe serían sin duda: Popper, Hayek y Berlin.
}

105 Obviamente se refiere al siglo XX. 
el resto del mundo» ${ }^{106}$. Allí constata el auténtico capitalismo popular, los beneficios de la privatización y la difusión de la propiedad, la supresión de los monopolios estatales deficitarios y la aparición de nuevas empresas para la creación de la riqueza.

Aunque cree firmemente en la democracia, precisa que, ella en sí misma, no genera bienestar. «Defiende los derechos humanos — dice—. Crea un clima de libertades que permite que los gobiernos sean fiscalizados, que haya renovación de los poderes políticos, pero por sí misma no crea prosperidad. Solo el mercado y la competencia la crean. Esa es la lección de la historia. La prosperidad es la consecuencia de un comercio en el cual se ofrecen ciertos servicios y ciertos productos a un mercado de consumidores. En esa competencia es donde va surgiendo la riqueza. Creo que este es el principio fundamental del liberalismo en lo económico» ${ }^{107}$.

«El liberalismo — afirma - es un abanico [...] Hay un núcleo, por supuesto, que si quieres puedes llamarlo dogmático: es la afirmación de que la libertad es un valor supremo y que es indivisible: que tiene una manifestación económica, cultural y política» ${ }^{108}$.

A partir de este ciclo, un tema reiterado en sus apreciaciones es la crítica al nacionalismo, que hoy en día atenta contra el proceso pacífico de la globalización. Considera que «es la cultura del inculto, la religión del espíritu de campanario y una cortina de humo detrás de la cual anidan el prejuicio, la violencia y a menudo el racismo» ${ }^{109}$. Para él, esa clase de exaltaciones es una grave amenaza a la cultura democrática, que garantiza la libertad individual.

Jean-François Revel, el agudo analista francés, asevera que «Mario Vargas Llosa es, sin duda, el escritor contemporáneo en cuya carrera ha existido mayor cabida para la política ${ }^{110}$. Sustenta la afirmación porque la mayor parte de la obra del autor arequipeño se relaciona de alguna manera con la compleja realidad política del Perú.

Por ejemplo: tomando en cuenta solamente sus novelas, nos damos con que La ciudad y los perros es un microcosmos del Perú, con su problemática del autoritarismo, diferencias sociales, políticas, raciales y económicas; Conversación en La Catedral muestra la opresión de la sociedad y los abusos que comete el Ochenio odriista a través de su aparato represivo; ¿Quién mató a Palomino Molero?, la forma en que la burocracia del gobierno militar silencia la muerte de un avionero.

El hablador relata las angustias del país y el mundo machiguenga, dentro de la compleja vida de la Amazonía; La Casa Verde trata de lo que es una constante en sus escritos:

\footnotetext{
106 Cfr. Vargas Llosa 1994: 11.

107 Cfr. Vargas Llosa 2003a: 110.

108 Cfr. Barnechea 1997: 292.

109 Cfr. Vargas Llosa 1994: 53.

110 Cfr. Vargas Llosa 2003b: 372.
} 
la corrupción de la sociedad peruana y su sistema político, e Historia de Mayta, los resultados del fanatismo y la violencia terrorista de Sendero Luminoso con sus fines criminales y las causas que lo motivan.

La guerra del fin del mundo, considerada por muchos su novela total, explora la realidad política latinoamericana a través de la revolución de los canudos en Brasil y advierte lúcidamente un fenómeno político de latente actualidad: la amenaza de la rebelión popular fundamentalista contra Occidente, guiada por un líder carismático.

El pez en el agua, que al publicarse causó una gran polémica en el Perú, intercala en capítulos sucesivos sus memorias y los hechos acontecidos durante la campaña electoral como candidato a la presidencia de la República; Lituma en los Andes demuestra su conocimiento del mundo andino, en donde todavía no se soluciona el problema del aislamiento de los grupos sociales; La fiesta del Chivo, acaso su novela más elogiada en los últimos años, muestra nuevamente el tema de la dictadura sin freno alguno, pero fuera del contexto peruano; sin embargo, su aparición en pleno apogeo del gobierno de Fujimori impacta grandemente en el país.

En sus ensayos, que son siempre magistrales y eruditos, no solo trata temas literarios, sino históricos, sociales y culturales de la realidad nacional e internacional. Los libros Contra viento y marea, Desafios a la libertad y El lenguaje de la pasión recogen artículos periodísticos, pronunciamientos políticos, gustos por la pintura, la música y el teatro y otros aspectos de la actualidad contemporánea, en la que es activo crítico con tribuna permanente. Vuelca su inquietud sobre el indigenismo en un ensayo como La utopía arcaica, acerca de la vida y obra de José María Arguedas, subrayando las contradictorias visiones existentes. El indio de hoy, para él, ha elegido la modernidad.

Los ensayos estrictamente literarios son invitaciones al placer de la lectura. Lo prueban: Garcia Márquez: historia de un deicidio, Cartas a un joven novelista, La orgía perpetua: Flaubert y "Madame Bovary», La verdad de las mentiras, La tentación de lo imposible, Botero: la suntuosa abundancia, Carta de batalla por «Tirant lo Blanc», Entre Sartre y Camus, George Grosz: un hombre triste y feroz, Historia secreta de una novela, Making Waves y Nationalismus Als Neve Bedrohung ${ }^{111}$.

Además de perspicaz espectador del acontecer internacional, es activo partícipe en el campo del debate de ideas: su interés por la política es permanente. Cuestiona a la izquierda anacrónica, autoritaria y populista de los hermanos Castro y Hugo Chávez, pero no escatima elogios a los gobiernos socialistas modernos que garantizan la libertad económica (Felipe González en España, Ricardo Lagos en Chile o Luiz Inácio Lula da

111 Sus obras han sido traducidas a más de veinte idiomas y también adaptadas al sistema Braille. 
Silva en Brasil), demostrando, de paso, que la afirmación de Octavio Paz, que cita Enrique Krauze, colaborador del gran poeta y ensayista, de que «Vargas Llosa tiene la pasión del converso» ${ }^{12}$, no es precisamente exacta.

No solo combate denodadamente las aventuras autoritarias de la derecha y la izquierda (Augusto Pinochet o Fidel Castro), sino también los crímenes del terrorismo, de Sendero Luminoso, del Movimiento Revolucionario Túpac Amaru (durante su campaña presidencial), de las FARC en Colombia y de ETA en España.

Agitador, «como debe ser todo liberal», según Hayek ${ }^{113}$, prologa entusiasmado libros beligerantes — como el Manual del perfecto idiota latinoamericano ${ }^{114}$ —, que incita acaloradas discusiones respecto de quienes apoyan el estatismo, socialismo, castrismo, sandinismo, o el sistema de dictadura perfecta del PRI, en México. Por eso, es frecuente leer en su columna periodística «Piedra de toque», publicada en una treintena de diarios, opiniones políticas acerca de acontecimientos de los más diferentes países del mundo o encontrarse, de repente, con libros como: Israel-Palestina, paz o guerra santa o Diario de Irak.

$\mathrm{Su}$ fama y prestigio crecen simultáneamente, a un nivel que ningún peruano ha logrado en el siglo XX. Obtiene numerosos premios internacionales (Cervantes, Príncipe de Asturias, María Moors Cabot, etcétera) y doctorados honoris causa de las universidades más prestigiosas (Harvard, Yale, Oxford, La Sorbona, Católica de Lovaina, etcétera). Hoy en día es el único latinoamericano miembro de la Real Academia Española de la Lengua. Es un verdadero ciudadano del mundo, como le gusta definirse, pues no deviene solamente en un incansable viajero, sino también en activo conferenciante. Las ideas políticas que profesa despiertan cada vez mayor interés en las universidades y foros de libre confrontación de pareceres. Las revistas Foreign Policy y Prospect, tras una encuesta, lo han ubicado entre los cien intelectuales más influyentes del mundo actual ${ }^{115}$.

En uno de sus encuentros con el Perú, durante la década de 1980, seducido por las investigaciones realizadas por el Instituto Libertad y Democracia sobre la economía informal, estimula la publicación de ese trabajo en un libro. Así, aparece El otro sendero ${ }^{116}$, que él prologa haciendo hincapié en que no idealiza la informalidad, sino que, "por el contrario, luego de mostrarnos sus logros, nos descubre las limitaciones que vivir al margen de la ley impone a las empresas informales, impidiéndoles crecer y planear el

112 Cfr. Varios 2008: 46.

113 Vargas Llosa consigna que Hayek antes de morir afirmó en una entrevista: «Todo liberal debe ser un agitador». Cfr. Vargas Llosa 1994: 106-107.

114 Escrito por Carlos Alberto Montaner, Plinio Apuleyo Mendoza y Álvaro Vargas Llosa. Cfr. Montaner 1996.

115 Por si fuera poco, recientemente el diario La Tercera, de Chile, lo ubica como el intelectual más influyente de América Latina (encuesta publicada en su edición del 21 setiembre de 2008).

116 Escrito por Enrique Ghersi, Mario Ghibellini y Hernando de Soto. 
futuro». Agrega: «El otro sendero defiende un proyecto social que supone una transformación no menos profunda que la que quisieran los sectores ideológicos más radicales» ${ }^{117}$.

El presidente Fernando Belaunde, durante su segundo gobierno ${ }^{118}$, le pide presidir la denominada Comisión Uchuraccay para investigar la matanza de ocho periodistas, ocurrida en las alturas de Ayacucho. Comprende la gravedad del caso y de inmediato acepta la solicitud para contribuir a esclarecer la verdad de un hecho que lo horroriza. En el informe final se manifiesta: «En medio de la gratuidad y su horror, el asesinato de los ocho periodistas sacó a la luz el verdadero problema peruano: el de la incomunicación que existe entre quienes, algunos mejor, otros peor, disfrutamos de condiciones de vida moderna, y esa mayoría que languidece en la más pavorosa miseria cuya vida es y solo puede ser 'bárbara' y a la que, por lo mismo, exigirle comportamientos 'civilizados' es una obscenidad. En esa tragedia había una lección que los peruanos todavía no queremos escuchar ${ }^{119}$ y llega a la convicción de que los periodistas fueron ejecutados por los comuneros de Uchuraccay, posiblemente, con la colaboración de otras comunidades iquichanas, al haber sido confundidos con un destacamento de senderistas. La izquierda a todo nivel intentó desacreditar el informe con ataques vociferantes a Vargas Llosa.

El fundador de Acción Popular, en posteriores conversaciones con él, advierte sus cualidades para el difícil arte de la política y el gobierno y le ofrece la Presidencia del Consejo de Ministros, invitación que declina al no obtener la libertad indispensable para conformar el gabinete ministerial.

En 1986, al año de ser elegido Alan García presidente de la República, se produce una sobrecogedora matanza en los penales de Lima, donde son ejecutados cientos de internos, en una operación acerca de la cual, hasta hoy, el Poder Judicial no administra justicia. Siendo la defensa de los derechos humanos una constante en su conducta cívica, en esa ocasión, escribe la carta abierta: «Una montaña de cadáveres», pidiendo se esclarezca lo acontecido ${ }^{120}$.

García gobierna aplicando medidas populistas hasta ocasionar un proceso inflacionario delirante que destruye la economía. Entonces, no se le ocurre nada mejor que estatizar la banca, idea abiertamente rechazada por la mayoría del país. Vargas Llosa conduce entonces una movilización que culmina en un mitin multitudinario en la plaza

117 Cfr. Vargas Llosa 1990a: 297-309.

118 Su reelección encarnó el rechazo a la dictadura militar.

119 Cfr. Vargas Llosa 1990b: 179-180.

120 Existe una Resolución de la Corte Interamericana de Derechos Humanos que exige al Estado peruano que investigue los hechos y sancione a los responsables. 
San Martín y neutraliza el cumplimiento del acto arbitrario ${ }^{121}$.

Meses después, sin habérselo propuesto, ve lanzada su candidatura a la presidencia de la República — con el apoyo de Luis Bedoya Reyes, connotado jurista de impecable trayectoria cívica, y de Fernando Belaunde, gobernante de honradez comprobada—, encabezando el Frente Democrático (alianza del Movimiento Libertad, los partidos Acción Popular y Popular Cristiano, además de la agrupación Solidaridad y Democracia), que empezará a cambiar la agenda ideológica del país.

Desde que el dictador Velasco ahogaba al Perú copiando trasnochadas tesis socialistas que nos convirtieron en un Estado gigante, pero paupérrimo y sin perspectivas, no se escuchaba un discurso enfatizando tan rigurosamente que la libertad política es inseparable de la libertad económica; ni que hiciera razonar mejor acerca de los beneficios que le reportan a un país la economía de mercado, el capitalismo popular, el resguardo de la propiedad privada, la promoción de la inversión nacional y extranjera, el control de la inflación y la reforma del Estado.

En plazas, medios de comunicación y centros académicos expone pedagógicamente su programa, que incluye la reforma de la educación, la privatización para difundir la propiedad, la reducción de ministerios, la supresión de los monopolios, la creación del sistema de Fondos Privados de Pensiones (AFP), el aumento de las exportaciones, entre otros temas. Ofrece, además, liderar personalmente, con energía pero cumpliendo con la Constitución y la ley, la lucha contra el terrorismo, que tiene en grave situación al país.

El APRA no vacila en envenenar las propuestas a través de una millonaria campaña televisiva, anunciando que tales postulados causarán la muerte de innumerables personas, mediante un shock económico que los dejará sin sus puestos de trabajo y con mentiras como las de que se suprimirá la educación gratuita. Lamentablemente, para un significativo sector de electores queda claro que el novelista gobernará solamente para los ricos. Apristas y comunistas celebran el éxito de su trabajo destructivo ${ }^{122}$.

Si bien Vargas Llosa gana la primera vuelta electoral, no obtiene el mandato claro que ha pedido y se propone declinar su participación en la segunda ronda, ofreciéndole a Fujimori su plan de gobierno, preparado cerca de dos años con profesionalismo por su

121 Vargas Llosa inicia la gestación del Movimiento Libertad con Frederick Cooper, Miguel Cruchaga, Luis Miró Quesada Garland y Fernando de Szyszlo, entre otros cien ciudadanos que suscriben el manifiesto fundacional.

122 Consciente de que el país es mayoritariamente católico, se siente en la obligación de declarar su agnosticismo, diferenciándolo del ateísmo. La confesión es malignamente aprovechada para descalificarlo, mezclando religión y política. 
equipo $^{123}$. Fujimori no lo acepta pese a carecer de programa ${ }^{124}$.

El voto de apristas y comunistas, de todas las tendencias, posibilita que Fujimori triunfe. Para lograr su objetivo, este ha contado con la organización de la mayoría de los fieles de las Iglesias evangélicas, con casi todo el aparato estatal y la prensa secuaz al gobierno aprista. (En la Cámara de Senadores, luego, se comprueba que el Sistema de Inteligencia Nacional (SIN) espió telefónicamente, con ilimitada impudicia, al candidato del Fredemo y a los principales dirigentes de su entorno, a lo largo de toda la campaña electoral).

Vencido Vargas Llosa ${ }^{125}$, sin resentimiento, solicita a los congresistas del Movimiento Libertad que sin pedir nada a cambio apoyen al nuevo régimen, que tiene por delante la tarea de reconstruir el país. Así se obró. En el poder, Fujimori, sin rubor, aplica como se sabe una política absolutamente contraria a la predicada durante su campaña electoral. El shock económico que ejecuta casi no tiene oposición popular, porque el trabajo pedagógico, duro, para que el ciudadano común entienda que es imprescindible ordenar la economía, ya ha sido realizado por Vargas Llosa. El nuevo gobernante inicia el proceso de reinserción del país dentro de la comunidad financiera internacional y recibe una generosa delegación de facultades legislativas del Congreso para la pacificación del país, reformar la economía y fomentar el empleo.

El 5 de abril de 1992, Fujimori con el auxilio de su siniestro asesor Vladimiro Montesinos y del pérfido comandante general del Ejército general Nicolás Hermoza Ríos da el golpe de Estado, en medio de graves acusaciones a su familia (hechas por su esposa, Susana Higuchi), agobiado por la crisis del país, que no puede controlar democráticamente, y, como cualquier dictador ${ }^{126}$, con el propósito de gobernar sin limitación constitucional con el apoyo de los militares vergonzosamente sometidos.

El Congreso vaca a Fujimori en el cargo por incapacidad moral y juramenta a Máxi-

123 Vargas Llosa igual que en su quehacer literario fue disciplinado en su trabajo político. Participó con dedicación en las reuniones del plan de gobierno dirigidas por Luis Bustamante.

Maniático de la puntualidad, se angustiaba al encontrar las concentraciones públicas sin gente. La preocupación desaparecía cuando las plazas se llenaban de simpatizantes y crecía el apoyo popular.

124 Quedó demostrado, porque el día que se comprometió a darlo a conocer a la prensa se hizo representar por su esposa, Susana Higuchi, quien se limitó a disculpar su ausencia, manifestando que estaba intoxicado por haber ingerido bacalao. En realidad, Fujimori nunca pensó llegar a la Presidencia de la República; por eso postuló simultáneamente a ese cargo y al de senador.

125 Contribuye a debilitar la independencia de la candidatura la criticada alianza electoral del Movimiento Libertad con Acción Popular y el Partido Popular Cristiano para formar el Fredemo, el exagerado gasto en publicidad de la primera vuelta electoral y la pugna de los candidatos parlamentarios por el voto preferencial. La campaña fue demasiado larga y se perdió la novedad. También hubo miedo en un importante sector del electorado, al cambio radical que proponía Vargas Llosa.

126 Luego Fujimori impulsó la dación de una Constitución en 1993, que le permitió su cuestionada reelección. 
mo San Román como presidente, quien «enfrentó la situación con valentía y desprendimiento, consciente de que su causa no contaba con respaldo popular» ${ }^{127}$. Asumió la función «sabiendo que no accedería al poder y que el mandato que iba a cumplir le exigiría duras pruebas. Tuvo sentido del deber y actuó firmemente en defensa de la Constitución» ${ }^{128}$.

Hasta la ruptura del orden constitucional, Vargas Llosa mantiene un cauto silencio $^{129}$, pero, producido este atropello, es el más combativo opositor del autodenominado "gobierno de emergencia y reconstrucción nacional», advirtiendo sobre sus nefastas secuelas ${ }^{130}$. Entonces, se inicia contra él una ignominiosa campaña de ataques.

La dictadura de Fujimori tiene resultados importantes en la economía, pero incurre en atroces transgresiones a los derechos humanos, en la lucha antiterrorista, que una parte significativa de la ciudadanía acepta sin importarle sus procedimientos.

Su gestión no es precisamente ejemplo de honradez. Lo prueban los cerca de trescientos millones de dólares de cuentas secretas provenientes de sus más poderosos y cercanos colaboradores que, durante los gobiernos de Paniagua y Toledo, son repatriados por jueces y fiscales extranjeros, hechos por los que la dictadura fujimorista es considerada internacionalmente entre las más podridas de la historia política latinoamericana.

Descubiertos los cuantiosos robos de su asesor Vladimiro Montesinos por la fiscal helvética Cornelia Cova, probados a través de los estados de cuenta de bancos suizos, que entregó el embajador de ese país en Lima a las autoridades, y al conocerse los sobornos de algunos parlamentarios de la oposición (en un video ${ }^{131}$ que muestra al congresista Alberto Kouri recibiendo un fajo de billetes de manos del propio Montesinos), Fujimori se vale de un viaje a Brunei, fuga al Japón para evitar acción de la justicia, asume la nacionalidad japonesa ${ }^{132}$, y renuncia por fax a la presidencia. El Congreso, al igual que el Parlamento disuelto, declara su vacancia en el cargo por incapacidad moral y de inmediato designa como presidente a Valentín Paniagua, que inicia el proceso anticorrupción

127 Cfr. Cateriano Bellido 1994: 315.

128 Cfr. Cateriano Bellido 1994: 315.

129 Mario Vargas Llosa ya no presidía en ese momento el Movimiento Libertad, pues el senador Luis Bustamante lo había reemplazado.

130 Nadie imaginó en ese momento los extremos de abuso y corrupción a los que llegarían Fujimori y Montesinos comprando conciencias.

131 ¿Para quién grababa Montesinos el pago de sus sobornos? ¿Eran los videos pruebas para incriminarse asimismo? ¿Servían para chantajear a los sobornados, o para dar cuenta de las millonarias cantidades de dinero utilizadas?

132 Japón permitió que la ejerciera sin reparo, a pesar de que lo había recibido, en varias oportunidades, en su condición de jefe de Estado del Perú. Fujimori llegó a postular como candidato al Senado japonés, para entorpecer su extradición de Chile al Perú, pero no ganó esa elección. El Poder Judicial de Chile, tiempo después, aprobó su entrega a los jueces peruanos, para responder por los gravísimos delitos cometidos, durante su gestión. 
para que el Poder Judicial investigue y sancione los delitos de la dictadura saliente. Vargas Llosa apoya decididamente la iniciativa y durante ese gobierno avala la creación de la Comisión de la Verdad establecida para indagar los actos violatorios de los derechos humanos ocurridos en el país desde 1980.

En las elecciones de 2001 respalda la candidatura presidencial de Alejandro Toledo, que, elegido sin mayoría parlamentaria, es debilitado políticamente por la oposición, que llega al extremo de pedir su vacancia. Vargas Llosa no se suma al cargamontón y aboga para que concluya su mandato.

En el proceso electoral de 2006, ante el dilema de elegir entre Alan García y Ollanta Humala, considera un peligro para la democracia la candidatura del comandante retirado, que tiene como inspiradores ideológicos a Juan Velasco y Hugo Chávez; pide —con reservas - el voto por García, el mismo personaje que con todos los medios a su alcance le impidió llegar a la presidencia.

Si bien el país no vive una auténtica revolución liberal, se ha distanciado del sistema estatista y anquilosado, iniciado por el funesto gobierno militar de Velasco ${ }^{133}$. A partir de 1990, empieza a constatar una trasformación en el campo económico. Fujimori, ante la gravedad de la crisis, no tuvo otra opción que aplicar algunas de las principales ideas que divulgó Vargas Llosa. Paniagua, en el tiempo fugaz que ejerció como jefe de Estado, no varió esa orientación, y Toledo, a pesar de los obstáculos, la mantuvo con firmeza, obteniendo logros significativos. García, actuando de manera totalmente contraria a la de su primer gobierno y a lo proclamado durante su campaña, continúa una política que respeta la libertad económica. Vargas Llosa no tiene reparo en elogiar la rectificación, porque beneficia al país.

Haber contribuido a guiar al Perú hacia un horizonte más libre y moderno, basado en los principios de una economía de mercado y un estado de derecho, es uno de los grandes aportes de Mario Vargas Llosa.

\section{Bibliografía}

ARMAS MARCELO, J. J. (2002). Vargas Llosa, el vicio de escribir. Madrid: Alfaguara.

BARNECHEA, Alfredo (1997). Peregrinos de la lengua. Madrid: Alfaguara.

CATERIANO BELLIDO, Pedro (1994). El Caso García. Lima: Ausonia.

HALPERÍN, Jorge (1997). Pensar el mundo. Barcelona: Planeta.

MONTANER, Carlos Alberto y otros (1996). Manual del perfecto idiota latinoamericano. Barcelona: Editorial Atlántida.

VALVERDE, José María (1963). «Prólogo». En: Vargas Llosa, Mario. La ciudad y los perros.

133 La dictadura de Velasco fue la más dañina que tuvo el país durante el siglo XX. Impulsó una serie de reformas socialistas totalitarias que destrozaron la economía, significando una verdadera hecatombe institucional. 
Barcelona: Seix Barral.

VARGAS LLOSA, Mario (1990a). «La revolución silenciosa», prólogo de El otro sendero. En: Contra viento y marea. Lima: Peisa, pp. 297-309.

(1990b). «Carta a unos familiares de luto». En: Contra viento y marea. Lima: Peisa, pp. 179-180.

(1993). El pez en el agua. Barcelona: Seix Barral.

- (1994). Desafios a la libertad. Madrid: El País y Aguilar.

(2003a). La vida en movimiento. Lima: Universidad Peruana de Ciencias Aplicadas (UPC).

$$
\text { (2003b). Vida que es palabra. México D. F.: Nueva Imagen. }
$$

VARIOS (2008). Las guerras de este mundo, sociedad, poder y ficción en la obra de Mario Vargas Llosa. Lima: Planeta. 


\section{RESENAas DE LOS}

AUTORES DE LOS TEXTOS 



\section{Eugenio Chang-Rodríguez}

Doctorado (P. D.) en Lingüística por la Universidad de Washington. Profesor de City University of New York (CUNY), director del Seminario Latinoamericano de la Universidad de Columbia, miembro de número de la Academia Norteamericana de la Lengua Española y académico correspondiente de la Real Academia Española y de las academias Peruana y Cubana de la Lengua. Ha recibido la Medalla de Honor del Congreso del Perú, la Orden al Mérito del Gobierno peruano y el doctorado honoris causa por las universidades nacionales Federico Villarreal y Enrique Guzmán y Valle, además de la de Atenas, Grecia. Algunos de sus veinticinco libros han sido traducidos al inglés, chino, coreano, árabe y griego.

\section{Osmar Gonzales Alvarado}

Sociólogo. Maestro en Ciencias Sociales por la Facultad Latinoamericana de Ciencias Sociales de México y doctor en Ciencia Social por el Colegio de México. Profesor de la Escuela de Postgrado en Ciencias Sociales de la Universidad Nacional Mayor de San Marcos y de la Unidad de Postgrado de Relaciones Internacionales y Ciencia Política de la Universidad Ricardo Palma. Ha sido subdirector de Investigaciones del Consejo Nacional de Ciencia y Tecnología de México, subdirector de la Biblioteca Nacional del Perú y asesor del Ministerio de Educación. Es director de la Casa Museo José Carlos Mariátegui, del Instituto Nacional de Cultura.

\section{Diego García-Sayán}

Abogado, juez (y vicepresidente) de la Corte Interamericana de Derechos Humanos, profesor universitario, director general de la Comisión Andina de Juristas y miembro de la Corte Permanente de Arbitraje (La Haya). Ha sido ministro de Justicia durante el gobierno de transición del presidente Valentín Paniagua y ministro de Relaciones Exteriores del Perú de 2001 a 2002. Ha sido alto funcionario de las Naciones Unidas como representante del secretario general en la verificación de los Acuerdos de Paz en El Salvador. En 2007 fue jefe de la Misión de Observación Electoral de la Organización de Estados Americanos en Guatemala. Ha sido congresista de la República del Perú. Es autor de diversos libros sobre derecho internacional, derechos humanos y desarrollo.

\section{José Agustín de la Puente Candamo}

Realizó sus estudios escolares en el Colegio de La Recoleta y estudió Letras y Derecho en la Universidad Católica del Perú. Doctor en Historia. Abogado. Profesor de Historia del Perú, en los periodos de Independencia y República, en la Universidad Católica. Miembro de número de la Academia Nacional de la Historia y de la Academia Peruana de la Lengua. 
Ha publicado San Martín y el Perú. Planteamiento doctrinario (1948); Notas sobre la causa de la Independencia del Perú (1970); Historia Maritima del Perú. La Independencia, 17901826 (dos volúmenes, 1974); Magdalena Vieja, recuerdos de una larga historia (1986); Teoría de la emancipación del Perú (1986); La Independencia del Perú (1992); Miguel Grau (2003); El Perú desde la intimidad. Epistolario de Manuel Candamo (2008).

\section{Liliana Checa}

Bachelor y Master of Arts por la Universidad de Nueva York (NYU). Master of Philosophy por el King's College de la Universidad de Londres. Ha ejercido la docencia en la Universidad Católica del Perú de 1985 a 2007 y en Corriente Alterna de 1985 a 1987. Ha publicado en los fondos editoriales de las universidades Católica, Peruana de Ciencias Aplicadas y Católica Sedes Sapientiae. Además en los diarios El Comercio y El Mundo, también en la revista Oiga, en la que tuvo a su cargo una columna en la sección cultural. Desde 1995 es docente de la Facultad de Periodismo de la Universidad Peruana de Ciencias Aplicadas y desde 2002 de la Facultad de Arquitectura.

\section{Renato D. Alarcón-Guzmán}

Médico psiquiatra, graduado en la Universidad Cayetano Heredia, con estudios de postgrado en la Escuela de Medicina de la Universidad Johns Hopkins, Baltimore, Maryland. Máster en Salud Pública de la Escuela de Salud Pública en la misma universidad. Su actividad académica se ha desarrollado en las universidades Cayetano Heredia; de Alabama en Birmingham, Alabama; Emory University en Atlanta, Georgia. Es profesor de Psiquiatría en el Departamento de Psiquiatría y Psicología, y director médico de la Unidad de Trastornos Afectivos en la Escuela de Medicina de la Clínica Mayo, Rochester, Minnesota. Distinguished Fellow de la Asociación Psiquiátrica Americana y del American College of Psychiatrists. Recientemente fue nombrado titular de la cátedra Honorio Delgado en la Universidad Cayetano Heredia. Profesor honorario o visitante en varias universidades de América Latina y Europa. Editor del texto de psiquiatría publicado bajo los auspicios de la Organización Panamericana de la Salud. Es también autor de libros y artículos acerca de psiquiatría cultural, trastornos del ánimo y de personalidad, y diagnóstico psiquiátrico.

\section{José Luis Sardón}

Abogado por la Universidad Católica Santa María, Arequipa. Máster en Ciencia Política por The American University, Washington D. C. Doctorando en Economía por la Escuela Superior de Economía y Administración de Empresas, Buenos Aires. Desde 2000 trabaja en la Universidad Peruana de Ciencias Aplicadas, donde es director del Área 
de Derecho y Economía de la Escuela de Postgrado. Se desempeña como árbitro de la Cámara de Comercio de Lima, presidente de la Comisión de Eliminación de Barreras Burocráticas del Instituto Nacional de Defensa de la Competencia y de la Protección de la Propiedad Intelectual y vocal de la Junta de Apelaciones de Reclamos de Usuarios del Organismo Supervisor de la Inversión en Energía y Minería.

\section{Arturo Salazar Larraín}

Bachiller en Derecho y doctor en Literatura por la Universidad Nacional Mayor de San Marcos, Premio Nacional de Fomento a la Cultura Javier Prado, doctor honoris causa de la Universidad Privada San Juan Bautista, docente de pregrado de Ciencias de la Comunicación en las universidades Particular de Piura, Garcilaso de la Vega, San Juan Bautista, Universidad Femenina y César Vallejo; y de postgrado en la Universidad San Martín de Porres; de seminario de Ciencias Sociales Brooklin Instituye/George Washington University. Asesor en Comunicaciones del Programa de Latinoamérica, de la Universidad de Texas en Austin. Periodista profesional de la Universidad Nacional Mayor de San Marcos, regidor y teniente alcalde del Concejo Provincial de Lima, redactor y director del diario La Prensa, de Lima; codirector del bisemanario Opinión Libre; autor de libros y ensayos diversos.

\section{Iván Alonso}

Bachiller en Humanidades con mención en Filosofía, de la Universidad Católica del Perú. Doctor (Ph. D.) en Economía de la Universidad de California, Los Ángeles. Profesor de Economía en la Universidad Peruana de Ciencias Aplicadas y profesor afiliado de Centrum Católica. Miembro de la Sociedad Mont Pelerin. Consultor independiente.

\section{Carlos Espá}

Abogado por la Universidad Católica del Perú. Máster en Ciencia Política por The American University, Washington, D. C. Becario Fulbright. Miembro de la Pi Alpha Sigma Nacional Political Science Honor Society y miembro asociado del Instituto de Estudios Internacionales, de la Universidad Católica. Ha trabajado como funcionario de la Organización de las Naciones Unidas para la Infancia y del Servicio Cultural e Informativo de Estados Unidos. Fue broadcaster internacional en la Voz de los Estados Unidos, en Washington D. C., y responsable de relaciones corporativas de la empresa Luz del Sur. En prensa escrita, se inició en el diario La Prensa. En el diario El Comercio fue coordinador de la Página Política y colaborador de la Página Editorial. En la revista Oiga, tuvo a su cargo la Página de Análisis Internacional. Ha sido director del diario Expreso. En televisión, ha sido panelista y moderador del programa Pulso, y entrevistador y comentarista de Buenos 
Días, Perú. Asimismo, condujo los noticieros de Canal Monitor y Global Televisión, y el programa Cuarto Poder, de América Televisión. En periodismo radial, ha trabajado como panelista en el programa Enfoque de los Sábados, de Radio Programas del Perú.

\section{Carlota Casalino Sen}

Historiadora. Doctora en Ciencias Sociales en la especialidad de Historia por la Universidad Nacional Mayor de San Marcos, magíster en Historia por la Universidad Católica del Perú, licenciada y bachiller en Historia por la Universidad Nacional Mayor de San Marcos. Desde 2003 tiene la cátedra de Historia de América en la especialidad de Historia de la Facultad de Ciencias Sociales de esta casa de estudios, así como el seminario de tesis de la misma especialidad. Desde 1995 dicta cursos de Historia en la Universidad Católica. Tiene diversas publicaciones sobre temas sociales (muerte, mujeres, expósitos, culíes, empresarios, grupos económicos), de cultura y de política (representaciones del Perú, construcción de los héroes patrios, procesos electorales, celebraciones y rituales públicos, instituciones e intelectuales-políticos, entre otros).

\section{Ismael Pinto Vargas}

Abogado, periodista profesional e historiador, por la Universidad Nacional Mayor de San Marcos. Ha publicado Pequeña antología de Moquegua (1960; 1987), Valdelomar en Moquegua (1988), El joven Sánchez (1990), Moquegua, perfil de una ciudad (2000), Sin perdón y sin olvido. Mercedes Cabello de Carbonera y su tiempo (2003).

\section{Rocío Chirinos Montalbetti}

Directora de Escuela de Capacitación Pedagógica (Lima). Doctorado en Historia por la Universidad de Navarra, España. (Magna cum Laude). Máster en Gestión Directiva Académica y máster en Asesoramiento Educativo Familiar del Centro Universitario Villanueva (España). Profesora en cursos de Educación Personalizada, en las maestrías de Asesoramiento Educativo Familiar y Gestión Directiva del Centro Universitario Villanueva, que se desarrollan en México, Ecuador, Chile y el Perú. Se dedica a la investigación y al asesoramiento de centros educativos. Conferencista nacional e internacional en temas de su especialidad. Ha publicado diversos textos sobre ciencias sociales e historia del Perú, por la Editorial Tercer Milenio.

\section{Santiago Pedraglio}

Ejerce el periodismo político. Es sociólogo y profesor universitario. Colabora en revistas universitarias y de índole académica. Codirigió el programa de televisión Rueda 
de Prensa y compartió la conducción de programas radiales de noticias. Estudió en las universidades Católica del Perú, La Sorbona de París y Nacional Mayor de San Marcos. Estudia un diplomado en Filosofía en la Universidad Antonio Ruiz de Montoya.

\section{Miguel Cruchaga}

Arquitecto egresado de la Universidad Nacional de Ingeniería. Profesor de Introducción a la Arquitectura y Teoría de la Arquitectura en la Facultad de Arquitectura de la Universidad Peruana de Ciencias Aplicadas. Fue profesor de la Facultad de Ingeniería de la Universidad Católica del Perú y de la Escuela de Decoración Interior de Miraflores. Es presidente de la Academia Peruana de Arquitectura y Urbanismo. Senador de la República de 1990 a 1992. Premio Nacional de Cultura 1972.

\section{Lourdes Flores Nano}

Abogada egresada de la Universidad Católica del Perú. Máster en Asesoría Jurídica de Empresas en el Instituto de Empresa de Madrid. Con estudios de Doctorado en la Universidad Complutense de Madrid. Rectora de la Universidad San Ignacio de Loyola. Presidenta del Partido Popular Cristiano. Vicepresidenta de la Internacional Demócrata Cristiana y de la Internacional Conservadora.

\section{Mariella Balbi}

Periodista e investigadora de la gastronomía peruana, cuenta con varias publicaciones sobre el tema, entre ellas La cocina según Sato, pescados y mariscos a la manera nikkei (1997), Los chifas en el Perú, historia y recetas (1999), Pisco es Perú (2003), Lúcuma, un regalo de sabor prehispánico (2003) y La cocina de Teresa Izquierdo (2006). También es autora del libro Szyszlo, travesía (2001), que recoge conversaciones con el pintor peruano Fernando de Szyszlo. Escribe para el diario El Comercio, de Lima.

\section{Giovanna Pollarolo}

Estudió Literatura y Lingüística en la Universidad Católica del Perú, donde obtuvo el bachillerato y la licenciatura. Es magíster en Literatura Latinoamericana por la Universidad Nacional Mayor de San Marcos, título obtenido en 2006 con la tesis titulada El proyecto nacional hegemónico en el discurso histórico y ficcional de Pedro Dávalos y Lissón (1863-1942). Actualmente se encuentra realizando estudios de doctorado en Literatura en la Universidad de Ottaway. Sus investigaciones están orientadas al estudio de los guiones para cine escritos por Manuel Puig. Ha publicado los poemarios Huerto de los olivos (1986), Entre mujeres solas (1991, que cuenta con varias reediciones) y La ceremonia del adiós (1997). En 
narrativa, la colección de relatos Atado de nervios (1999) y la novela Dos veces por semana (2008). Como guionista de cine, coescribió los largometrajes La boca del lobo, Caídos del cielo y Pantaleón y las visitadoras, entre otros.

\section{Daniel Córdova Cayo}

Doctor en Economía Internacional de la Universidad de Grenoble (Francia) y Licenciado en Economía de la Universidad del Pacífico (Lima). Decano de la Facultad de Economía de la Universidad Peruana de Ciencias Aplicadas (UPC), presidente del Instituto de Empresa Invertir y de Invertir Consultores Asociados. Sus recientes publicaciones son Manual de gobierno corporativo para empresas familiares (2006), Gestión privada de los servicios públicos. Las tarifas y el fin de los mitos (2007) y los artículos «Amid Hopelessness, Hopeful Investment: The Case of the Añaños Family and Kola Real» y "Defeating Poverty Doing Business: The Case of the Flores Family and Topy Top» (en Lessons From the Poor. Triumph of the Entrepreneurial Spirit, editado por Álvaro Vargas Llosa, The Independent Institute, 2008). Es columnista del diario El Comercio y miembro de la Sociedad Mont-Pellerin y de la Eisenhower Fellowship, institución de la que fue becario en 2003 .

\section{Gonzalo Carranza Bigotti}

Bachiller en Periodismo con mención en Economía de la Universidad Peruana de Ciencias Aplicadas (UPC). Es analista de Apoyo Publicaciones, empresa editora de las revistas Semana Económica y Perú Económico, donde cubre los sectores de banca y finanzas, consumo masivo y telecomunicaciones. Además, ha publicado entrevistas, crónicas y artículos de opinión en los diarios El Comercio y Perú.21, así como en las revistas Cosas, Cosas Hombre y Helio. Fue director general del Grupo Convergencia, una asociación de universitarios que busca promover nuevos espacios de discusión.

\section{Pedro Cateriano Bellido}

Abogado por la Universidad Católica del Perú. Especialista en Derecho Constitucional. Ha ejercido la cátedra universitaria durante quince años. Diputado de 1990 a 1992. A raíz de esta experiencia publicó El Caso García. Viceministro de Justicia de 2001 a 2002, lapso en el que impulsó la repatriación de fondos ilícitos al país. Sus artículos periodísticos los divulga la Agencia Interamericana de Prensa Económica. En 2007 participó como observador electoral de la Organización de Estados Americanos en las elecciones de Guatemala. Realiza labores de consultoría y ejerce su profesión de manera independiente. 


\section{Otras Publicaciones del FONDO EDITORIAL DE LA UPC}

1995

Elecciones Municipales de Lima. Período 1996-1998

Uno de los dos

Los candidatos explican sus propuestas

(UPC/USAID e IFES)

1996

Agenda Nacional de Gobernabilidad Democrática:

Primera Jornada Nacional

(UPC/Programa de las Naciones Unidas para el Desarrollo, PNUD)

Doblado, Juan Carlos y Queirolo, Alfredo

Introducción al diseño arquitectónico

1997

Miró Quesada Garland, Alejandro; Peirano, Luis;

Santistevan de Noriega, Jorge y Szyszlo, Fernando de

Homenaje a Ricardo Blume

(UPC/OXY)

1998

Savater, Fernando

Conferencias en Lima

Ética y periodismo

Alegría y responsabilidad

El valor de educar

Bryce Echenique, Alfredo

Charla Magistral

Del humor quevedesco a la ironía cervantina

Bustamante Belaunde, Luis

La nueva universidad

1999

Gallegos, Héctor

La ingeniería 
Doblado, Juan Carlos y Queirolo, Alfredo

Introducción al diseño arquitectónico

Montaner, Carlos Alberto

Charla Magistral

Retos al pensamiento moderno a las puertas de un siglo nuevo

Villanueva Chang, Julio

Mariposas y murciélagos. Crónicas y perfiles

Ugaz Sánchez-Moreno, José Carlos

Prensa juzgada.

Treinta años de juicios a periodistas peruanos (1969-1999)

(UPC/IPYS/The Freedom Forum)

2000

Fischman, David

El camino del lider

(UPC/El Comercio)

Jacobs, Mónica; Mory, Eliana y Vélez, Odette

Etica y politica.

El arte de vivir y convivir

Fischman, David

El espejo del líder

(UPC/El Comercio)

Bustamante Belaunde, Luis; Carpio, Úrsula; Szyszlo, Fernando de; Freundt-Thurne, Úrsula; Rodríguez Saavedra, Carlos y Wehr, Elke Homenaje a Alonso Cueto

Fleisig, Heywood W.; De la Peña, Nuria y

Cantuarias Salaverry, Fernando

Trabas legales al crédito en el Perú: garantías mobiliarias

(UPC/CEAL)

Bayly, Jaime

Conferencia en Lima

Realidad y ficción en la literatura de Bayly

Avendaño Valdez, Jorge; Bullard González, Alfredo; Cantuarias Salaverry, Fernando (Editor); Endo Olascuaga, Víctor; Fernández Cruz, Gastón; Montúfar Sarmiento, Juan Felipe; Mosqueira Medina, Edgardo; Muñiz Ziches, Jorge; Patrón Salinas, Carlos A.; Pizarro Aranguren, Luis; Priest, George L. y Salinas Rivas, Sergio ¿Por qué hay que cambiar el Código Civil? 
Galván, Liliana

Creatividad para el cambio. Innovación en la vida y la empresa

(UPC/El Comercio)

Vargas Llosa, Mario

Conferencia Magistral

La literatura y la vida

Balbi, Mariella

Szyszlo. Travesía

(UPC/EDEGEL)

Somoza, José Carlos

Conferencia en Lima

Tigres y espejos. Literatura como pasión y como reflexión

Gallegos, Héctor

Ética. La ingeniería

Segunda edición

Baird, Douglas G.; Craswell, Richard; Dam, Kenneth W.; Epstein,

Richard A.; Levmore, Saul; Miller, Geoffrey P.; Picker, Randal C.; Posner,

Eric A. (Compilador); Posner, Richard A.; Ramseyer, J. Mark; Sunstein,

Cass R. y Sykes, Alan O. Law \& Economics

El Análisis Económico del Derecho y la Escuela de Chicago

Lecturas en honor de Ronald Coase

Cisneros, Luis Jaime; Lemlij, Moisés; MacLean, Roberto y

Santuc, Vicente

Conversatorio

Lenguaje, leyes y religión: realidad y apariencia

Aljovín, Cayetana; Arosemena, Rodrigo; Cipriano, Manuel; Cremades, Javier; Door, Roberto C.; Freundt-Thurne, Úrsula; Paredes, Mariella; Quiñones, María Teresa; Rivadeneyra, Juan; Rodríguez, Antonio; Rozas, Hortencia; Tovar, Gloria y Vizcarra, Maite (Compiladora)

La sociedad de la información

Nuevas tendencias de las telecomunicaciones

(UPC/TIM PERÚ S. A. C./CENTIC)

De Olarte, Jorge (Editor); Jiménez, Fernando; Linares, Eduardo y

Rodríguez, José

Base de datos de sistemas constructivos para edificación

que se utilizan en el Perú

(UPC/CONCYTEC) 
Montero, Rosa

Conferencia de Autor

Más bello que el silencio

¿Por qué necesitamos escribir y leer novelas?

Epstein, Richard A.

Principios para una sociedad libre

Reconciliando la libertad individual con el bien común

Kuczynski, Pedro Pablo y Williamson, John (editores)

Después del Consenso de Washington. Relanzando el crecimiento y las reformas en América Latina

(UPC/The Institute for International Economics)

Cueto, Alonso

Mario Vargas Llosa. La vida en movimiento

(UPC/Repsol YPF Perú)

Sardón de Taboada, José Luis (editor)

Revista de Economía y Derecho

Número 1

Barraza Eléspuru, Ernesto

La mujer que barrió el desierto. María Reiche

(UPC/ICPNA)

Sardón de Taboada, José Luis (editor)

Revista de Economía y Derecho

Número 2

Salmón Jordán, Jorge

Comunicación: más allá de la imagen

Day, Henry; Eguren, Mons. José Antonio; MacLean, Roberto y

Rey de Castro, Álvaro

Conversatorio

El amor como aventura, desafio, disciplina y servicio

Sardón de Taboada, José Luis (editor)

Revista de Economía y Derecho

Número 3

Garrido-Lecca, Celso

Retablos Sinfónicos CD 002 
Sardón de Taboada, José Luis (editor)

Revista de Economía y Derecho

Número 4

Galván, Liliana Creatividad para el Cambio.

Innovación para la vida y la empresa

Segunda edición

Cárdenas Menacho, Luchín

Publicidad

El placer de crear

Benegas Lynch (h), Alberto

Charla Magistral

Liberalismo, estatismo y democracia.

Instituciones políticas y progreso económico

Sardón de Taboada, José Luis (editor)

Revista de Economía y Derecho

Número 5

Aguirre, Mauricio y Llaque, Paúl (editores)

Redacción académica. Fundamentos y estrategias

Mory, Eliana y Vélez, Odette (editoras)

La exigente incomodidad

Ética y profesiones

Sardón de Taboada, José Luis (editor)

Revista de Economía y Derecho

Número 6

MacLean U., Roberto G.

Una justicia para el habitante común

Sardón de Taboada, José Luis (editor)

Revista de Economía y Derecho

Número 7

Sardón de Taboada, José Luis (editor)

Revista de Economía y Derecho

Número 8

Lazarte Molina, Jorge E.

Libertad de empresa y servicio público

El concepto de servicio público en el Perú 
Chu Rubio, Manuel

Finanzas para no financieros

2006

Sardón de Taboada, José Luis (editor)

Revista de Economía y Derecho

Verano 2006, Vol. 3, No 9

Sardón de Taboada, José Luis (editor)

Revista de Economía y Derecho

Otoño 2006, Vol. 3, No 10

Córdova Gastiaburu, Paula (editora)

¿Cambio o muerte de las lenguas?

Reflexiones sobre la diversidad lingüistica, social y cultural del Perú

Sardón de Taboada, José Luis (editor)

Revista de Economía y Derecho

Invierno 2006, Vol. 3, No 11

Savater, Fernando

Charla Magistral

Antropología de la Libertad

Sardón de Taboada, José Luis (editor)

Revista de Economía y Derecho

Primavera 2006, Vol. 3, No 12

Segerfeldt, Fredrik

Agua Privada para Todos

Cómo la empresa y el mercado pueden solucionar la crisis mundial del agua

(UPC/Cato Institute)

Tooley, James y Dixon, Pauline

Educación Privada y Pobreza

Un estudio de las escuelas privadas que sirven en paises de bajos ingresos

(UPC/Cato Institute)

Sardón de Taboada, José Luis (editor)

Revista de Economía y Derecho

Verano 2007, Vol. 4, No 13

Córdova Gastiaburu, Paula (editora)

¿Cambio o muerte de las lenguas?

Reflexiones sobre la diversidad lingüistica, social y cultural del Perú

Segunda edición 
Checa, Liliana; Dextre, Sergio y Luis Villacorta

Arte de los siglos XIV al XVII. Del ocaso al amanecer: una breve historia

Segunda edición

Aguirre, Mauricio y Estrada, Christian (editores)

Redactar en la universidad. Conceptos y técnicas fundamentales

Sardón de Taboada, José Luis (editor)

Revista de Economía y Derecho

Otoño 2007, Vol. 4, No 14

Cantuarias Salaverry, Fernando

Arbitraje comercial y de las inversiones

Rodríguez, Gustavo

Juan Diego Flórez. Notas de una voz

(UPC/BIF)

Sardón de Taboada, José Luis (editor)

Revista de Economía y Derecho

Invierno 2007, Vol. 4, No 15

Córdova Cayo, Daniel

Gestión privada de los servicios públicos. Las tarifas y el fin de los mitos

(UPC/Invertir)

Aguirre, Mauricio; Calero, Joel; Estrada, Christian y Llaque, Paúl (editores)

Estrategias para redactar. Procedimientos fundamentales

Eyzaguirre del Sante, Hugo (editor)

Instituciones y desarrollo. La reforma institucional. La experiencia chilena

(UPC/CAF)

Sardón de Taboada, José Luis (editor)

Revista de Economía y Derecho

Primavera 2007, Vol. 4, No 16

Chu Rubio, Manuel

Mis finanzas personales

Pasquel, Enrique; Patrón, Carlos A. y Gabriela Pérez Costa (compiladores) El derecho de la competencia desleal

Epstein, Richard A.

El libre mercado bajo amenaza. Cárteles, políticas y bienestar social 
Sardón de Taboada, José Luis (editor)

Revista de Economía y Derecho

Verano 2008, Vol. 5, No 17

Sardón de Taboada, José Luis (editor)

Revista de Economía y Derecho

Otoño 2008, Vol. 5, No 18

Alvarado-Ortiz Ureta, Carlos y Blanco Blasco, Teresa

Alimentos. Bromatología

Segunda edición

(UPC/Fundación Ajinomoto)

Sardón de Taboada, José Luis (editor)

Revista de Economía y Derecho

Invierno 2008, Vol. 5, No 19

Medianero Burga, David

Proyectos de inversión pública. Teoría e instrumentos de identificación, formulación y evaluación

(UPC/Cempro)

Aguirre, Mauricio y Estrada, Christian (editores)

Redactar en la universidad. Conceptos y técnicas fundamentales

Segunda edición

Bello Gordillo, Christian

Principio de Irretroactividad de la Ley Penal: Fundamentos y Alcances

Sardón de Taboada, José Luis (editor)

Revista de Economía y Derecho

Primavera 2008, Vol. 5, No 20

Huamán Pulgar Vidal, Laura y Ríos Ramos, Franklin

Metodologías para implantar la estrategia: diseño organizacional de la empresa

Norberg, Johan

Cuatro décadas que cambiaron nuestro planeta

(UPC/Cato Institute) 
Eyzaguirre del Sante, Hugo (editor)

Libertad económica y lucha contra la pobreza. Libertad económica y estado de derecho. Empresa, gobierno y lucha contra la pobreza.

(UPC/CAF)

Cantuarias Salaverry, Fernando y Stucchi López Raygada, Pierino (compiladores) TLC Perú-Estados Unidos: contenido y aplicación

Cateriano Bellido, Pedro (compilador)

Veinte peruanos del siglo XX

(UPC/Repsol YPF) 


\section{AUTORES}

Eugenio Chang-Rodríguez

Osmar Gonzales Alvarado

Diego García-Sayán

José Agustín de la Puente Candamo

Liliana Checa

Renato D. Alarcón-Guzmán

José Luis Sardón

Arturo Salazar Larraín

Iván Alonso

Carlos Espá

Carlota Casalino Sen

Ismael Pinto Vargas

Rocío Chirinos Montalbetti

Santiago Pedraglio

Miguel Cruchaga

Lourdes Flores Nano

Mariella Balbi

Giovanna Pollarolo

Daniel Córdova Cayo

Pedro Cateriano Bellido 